Peter Rosenberg / Konstanze Jungbluth / Dagna Zinkhahn Rhobodes (eds.)

\title{
Linguistic Construction of Ethnic Borders
}

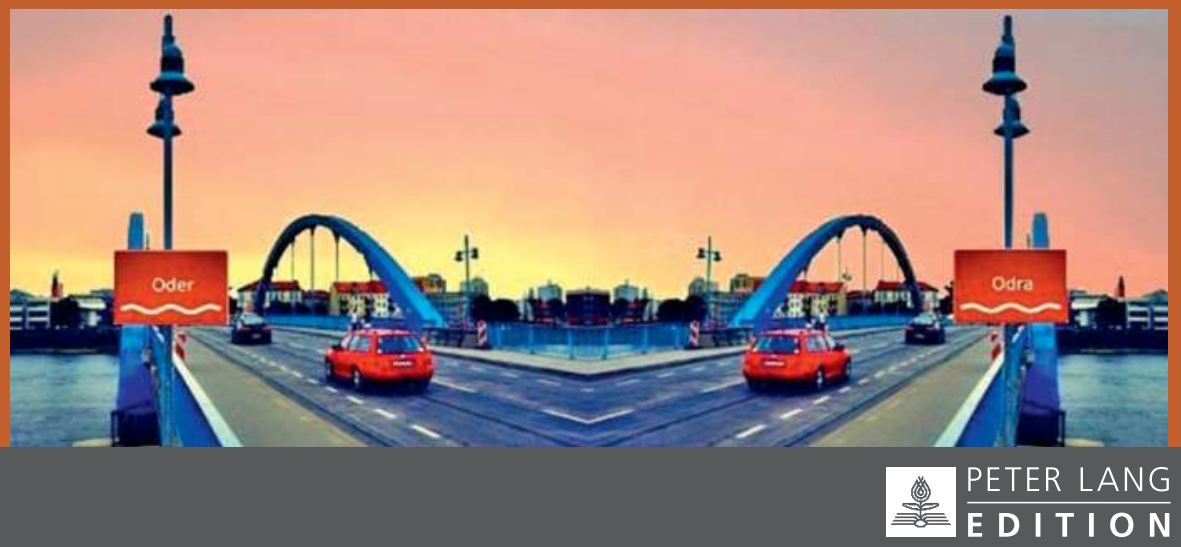




\section{Peter Rosenberg / Konstanze Jungbluth / \\ Dagna Zinkhahn Rhobodes (eds.)}

\section{Linguistic Construction of Ethnic Borders}

This volume focuses on the linguistic constructs involved in ethnic borders. Ethnic borders have proven themselves to be surprisingly long-lived: in nearly all European countries and beyond, border demarcation, exclusion of foreigners, and minority conflicts are some of the most persistent challenges for nations and societies. Which linguistic factors play a role in the formation of these borders, especially those drawn along ethnic lines? Which linguistic constructs contribute to the negotiation, establishment and main- tenance of ethnic groups and identities? Under which conditions can processes of linguistic convergence, hybrids, or transcultural identities be observed?

\section{The Editors}

Peter Rosenberg is Lecturer, Konstanze Jungbluth is Professor and Dagna Zinkhahn Rhobodes is Postgraduate at the Faculty of Social and Cultural Studies, Viadrina European University in Frankfurt/Oder. 
Linguistic Construction of Ethnic Borders 

Peter Rosenberg / Konstanze Jungbluth / Dagna Zinkhahn Rhobodes (eds.)

\section{Linguistic Construction of Ethnic Borders}


Bibliographic Information published by the Deutsche Nationalbibliothek The Deutsche Nationalbibliothek lists this publication in the Deutsche Nationalbibliografie; detailed bibliographic data is available in the internet at http://dnb.d-nb.de.

\section{Library of Congress Cataloging-in-Publication Data}

Linguistic Construction of Ethnic Borders / Rosenberg, Peter ; Jungbluth, Konstanze ; Zinkhahn Rhobodes, Dagna (eds.).

pages $\mathrm{cm}$

ISBN 978-3-631-65377-7 (Print) - ISBN 978-3-653-04595-6 (E-Book) 1. Group identity. 2. Ethnicity. 3. Linguistic analysis (Linguistics) 4. Anthropological linguistics. 5. Sociolinguistics. I. Rosenberg, Peter, 1953- editor. II. Jungbluth, Konstanze, 1958- editor. III. Zinkhahn Rhobodes, Dagna, 1986editor.

P40.5.G76L46 2015

$306.44089-\mathrm{dc} 23$

2015030249

This book is an open access book and available on www.oapen.org and www.peterlang.com. It is distributed under the terms of the Creative Commons Attribution Noncommercial, No Derivatives (CC-BY-NC-ND) License.

Cover Image: @ Rüdiger Hahn

ISBN 978-3-631-65377-7 (Print)

E-ISBN 978-3-653-04595-6 (E-Book)

DOI 10.3726/978-3-653-04595-6

(c) Peter Lang GmbH

Internationaler Verlag der Wissenschaften

Frankfurt am Main 2015

All rights reserved.

Peter Lang Edition is an Imprint of Peter Lang GmbH.

Peter Lang - Frankfurt am Main · Bern · Bruxelles · New York ·

Oxford $\cdot$ Warszawa $\cdot$ Wien

All parts of this publication are protected by copyright. Any utilisation outside the strict limits of the copyright law, without the permission of the publisher, is forbidden and liable to prosecution.

This publication has been peer reviewed.

www.peterlang.com 


\section{Table of Contents}

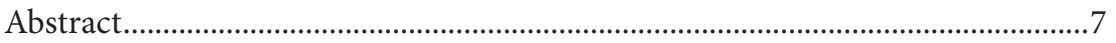

Vorwort der Herausgeber .....................................................................................

\section{Group boundaries and identity}

Stefan Rabanus and Haykanush Barseghyan

Language Choice and Identity in Post-Soviet Armenia..

Rita Vallentin

Linguistic Strategies of Constructing Durable and Permeable

Ethnic Boundaries in a Brazilian Quilombo Community

Bernhard Brehmer

The Cyrillic Script as a Boundary Marker between "Insiders"

and "Outsiders": Metalinguistic Discourse about Script Choices in

Slavic-German Bilingual Computer-Mediated Communication.

\section{Ethnic boundaries and minorities}

Lia Melikishvili and Natia Jalabadze

Language and Ethnic Boundaries in Multiethnic Georgia

Maria Klessmann

Roma school mediation in Germany - Its Effects and Limitations

Sascha Wölck and Christina Rogers

Labeling difference - On discrimination and the social standing of children fathered by US soldiers during the Vietnam War

Harald Weydt

Linguistic borders - language conflicts. Pleading for recognition

of their reality

\section{Boundaries and language islands}

Peter Rosenberg

Anything goes? The gains and losses of the constructivist view on ethnicity:

Some considerations based on German „language islands" studies.

Hans C. Boas

Linguistic splits along religious lines: The role of language maintenance among Catholics and Lutherans in Texas 
Samantha Litty, Christine Evans and Joseph Salmons

Gray zones: The fluidity of Wisconsin German language and identification..... 183

\section{Language borders and discourse}

Konstanze Jungbluth

Crossing the Border, Closing the Gap: Otherness in Language Use 209

Dagna Zinkhahn Rhobodes

The permeability of language borders on the example of German-Polish language mixing 229

Helena Topa Valentim

Boundary, a metalinguistic concept at the core of language deformability 249 


\section{Abstract}

Social and ethnic borders have proven themselves to be surprisingly long-lived. In nearly all European countries and beyond, border demarcation, exclusion of foreigners and minority conflicts are some of the most persistent challenges for nations and societies.

European nations are becoming more integrated, Russia has a long tradition as a multi-ethnic nation, and the U.S. is considered the prime example of a land of immigration. Nevertheless, migration, ethnic differences and social integration remain a political issue with great potential for social mobilization. Ethnicity clearly outlives any processes of convergence. How can the story of this phenomenon's "success" be explained? Which linguistic factors play a role in the formation of these borders (especially those drawn along ethnic lines)? What roles do language and language varieties play in the discourse surrounding analyses of social relationships that are deemed legitimate? Which linguistic constructs contribute to the negotiation, establishment and maintenance of ethnic groups and identities? Under which conditions can processes of linguistic convergence, hybrids, or transcultural identities be observed?

The linguistic constructs involved in ethnic borders are the primary focus of this volume, which draws on presentations given by scholars from Europe, South Africa, North and South America during the international conference Linguistic Construction of Social Borders (2013 in Frankfurt/Oder and Słubice).

This complex area of study will investigate the following themes:

- Group boundaries and identity

- Ethnic boundaries and minorities

- Boundaries and language islands

- Language borders and discourse

\section{Keywords:}

group boundaries, ethnic boundaries, identity, minorities, language islands, language borders, discourse

\section{Schlagworte:}

Gruppengrenzen, ethnische Grenzen, Identität, Minderheiten, Sprachinseln, Sprachgrenzen, Diskurs 



\section{Vorwort der Herausgeber}

Ethnische Grenzen erweisen sich als erstaunlich langlebig.

In nahezu allen europäischen Ländern und weit darüber hinaus gehören ethnische Grenzziehungen, Selbst- und Fremdausgrenzung, Minderheitenkonflikte zu den anhaltenden Herausforderungen in Staat und Gesellschaft.

Europa wächst zusammen, Russland hat eine lange Tradition als Vielvölkerstaat, die USA gelten als das klassische Einwanderungsland schlechthin. Dennoch sind Migration, ethnische Unterschiede und soziale Integration ein Politikum von erheblichem Mobilisierungspotenzial. Ethnizität überlebt offenbar alle Konvergenzprozesse. Wie lässt sich die „Erfolgsgeschichte“ dieser Kategorie erklären? Welche sprachlichen Mittel der Konstruktion sozialer - insbesondere ethnischer - Grenzen tragen hierzu bei? Welche Rolle spielen Sprachen und Sprachvarietäten im Diskurs um die als legitim angesehene Deutung gesellschaftlicher Verhältnisse? Welche sprachlichen Konstruktionsmittel sind es, mit denen die Existenz, die Berechtigung und die Aufrechterhaltung sozialer - insbesondere ethnischer - Gruppen ausgehandelt werden? Unter welchen Bedingungen sind sprachliche Konvergenzprozesse sowie hybride und transkulturelle Identitätskonstruktionen zu beobachten? Was unterscheidet einen „europäischen“ von einem „post-sowjetischen“ und jenen von einem US-amerikanischen Blick auf diese Thematik? Und inwieweit erweitern südafrikanische und südamerikanische Perspektiven den Blick auf diese Fragestellung?

Der vorliegende Sammelband enthält Beiträge, die in vier Themenbereiche gegliedert sind.

Das Kapitel Group boundaries and identity ist der Diskussion über die Entstehung von Gruppengrenzziehungen und der Aushandlung von Gruppenidentitäten gewidmet. Stefan Rabanus und Haykanush Barseghyan (Eriwan) verdeutlichten anhand der Ergebnisse von Interviews und Fragebögen, wie durch die Wahl der russischen oder armenischen Sprache die Identität der Sprecher im postsowjetischen Armenien konstruiert wird. Rita Vallentin (Frankfurt/Oder) analysiert sprachliche Mittel zur Herstellung von durablen und permeablen sozialen Grenzen in der Quilombo-Gemeinschaft in Brasilien. Bernhard Brehmer (Greifswald) geht der Frage nach, welche Bedeutung die Wahl der kyrillischen Schrift für die symbolische Konstruktion einer „russischen“ Identität unter slavisch-deutschen bilingualen Jugendlichen hat.

In dem Kapitel Ethnic boundaries and minorities stehen insbesondere die ethnischen Grenzziehungen, Selbst- und Fremdausgrenzung und Minderheitenkonflikte im Mittelpunkt. Gemeinsamer Bezugspunkt ist die Frage, welche sprachlichen Kon- 
struktionsmittel sind es, mit denen die Existenz, die Berechtigung und die Aufrechterhaltung sozialer - insbesondere ethnischer - Gruppen ausgehandelt werden? Lia Melikishvili and Natia Jalabadze (Tbilisi) beleuchten die Rolle von Sprache in der Etablierung von ethnischen Grenzen im multiethnischen Georgien. Maria Klessmann (Frankfurt/Oder) untersucht Rollenzuschreibungen und Selbstpositionierungen am Beispiel von Roma-Schulmediatoren/innen in Deutschland. Sascha Wölck (Berlin) und Christine Rogers (Dresden) diskutieren die Diskriminierung und den sozialen Status von vietnamesisch-amerikanischen Kriegskindern. Harald Weydt (Frankfurt/Oder) interpretiert Sprachkonflikte als Versuche, die eigene Sprache als dominierend durchzusetzen und damit entscheidende Privilegien für die eigene Gruppe zu erlangen. Er zeigt Verfahren auf, Sprachkonflikte zu neutralisieren.

Das Kapitel Boundaries and language islands ist dem Thema der ethnischen Grenzziehung in deutschen Sprachinseln gewidmet. Peter Rosenberg (Frankfurt/ Oder) behandelt die Rolle der sprachlichen Grenzen in der Konstruktion von ethnischer Distinktivität am Beispiel deutscher Sprachinseln in Brasilien und in Russland. Ferner berichtet Hans Boas (Austin) über den Spracherhalt deutscher katholischer und lutheranischer Auswanderer und ihrer Nachfahrern in Texas. Joe Salmons, Samantha Litty und Christine Evans (Madison) zeigen am Beispiel der Entstehung und des Gebrauchs deutscher Varietäten in Wisconsin, wie ehemalige ethnische und regionale Grenzen um- und abgebaut werden.

Der Fokus des letzten Kapitels - Language borders and discourse - liegt auf der interaktiven Aushandlung von Grenzen sowie auf der Analyse der sprachlichen Grenze aus struktureller Perspektive. Konstanze Jungbluth (Frankfurt/Oder) behandelt die Konzepte we und the others in den sozialen Interaktionen und diskutiert die Grenzziehungen zwischen den Dialogpartnern in face-to-faceKonversationen. Dagna Zinkhahn Rhobodes (Frankfurt/Oder) untersucht das Konzept der Permeabilität der sprachlichen Grenzen am Beispiel des Sprachgebrauchs an der deutsch-polnischen Grenze. Der Beitrag von Helena Valentim (Lisboa) fokussiert die Grenze als ein metalinguistisches Konzept.

Die sprachliche Konstruktion ethnischer Grenzen steht im Mittelpunkt des Sammelbandes, der ausgewählte Vorträge der internationalen Tagung Linguistic construction of social borders (2013 in Frankfurt/Oder und Słubice) enthält. Unter diesem Thema versammelte die Tagung in Kooperation mit dem Deutschpolnischen Forschungsinstitut und dem Viadrina Center B/Orders in Motion Wissenschaftler aus Europa, Südafrika, Nord- und Südamerika aus verschiedenen sprach- und sozialwissenschaftlichen Disziplinen, die das Thema der "Grenze“ aus soziolinguistischer Perspektive diskutierten. 


\section{Group boundaries and identity}





\title{
Stefan Rabanus and Haykanush Barseghyan
}

(Yerevan)

\section{Language Choice and Identity in Post-Soviet Armenia}

\begin{abstract}
Der vorliegende Beitrag behandelt Typen von Identitätskonstruktion durch Sprachwahl von Armenisch und Russisch im postsowjetischen Armenien. Für das Selbstverständnis der armenischen Gesellschaft war die eigene Sprache, Schrift und Literatur stets fundamental. Sie hat wesentlich dazu beigetragen, dass das Bewusstsein von der armenischen Nation über die Jahrhunderte einer Geschichte, die von fremder Herrschaft, Vertreibungen bis hin zum Genozid und die Ansiedlung des größten Teils der Armenier im Ausland geprägt war, nicht verlorengegangen ist. Dennoch hat die jahrhundertelang fehlende Eigenstaatlichkeit dazu geführt, dass Armenisch nicht den Status einer vollen ,Ausbausprache` erreichen konnte. Die Zugehörigkeit des Gebiets der heutigen Republik Armenien (Gebiet des Ostarmenischen) zum zaristischen Russland bzw. zur Sowjetunion (1813-1991) hat dazu geführt, dass die russische Sprache zahlreiche gehobene Funktionsdomänen übernommen hat. Mit der Unabhängigkeit der Republik Armenien 1991 wurde das Armenische die einzige offizielle Staatssprache. Der Bilinguismus Armenisch-Russisch ist aber bis heute weit verbreitet. Der vorliegende Beitrag ist eine soziolinguistische Untersuchung (auf der Basis von 37 fragebogengeleiteten Einzelinterviews) zu Spracheinstellungen, Faktoren der Sprachwahl und Sprachgebrauch, in der Antworten auf die folgenden Fragen gegeben werden: 1. Wird das Russische in Armenien als eigene, zweite Sprache Armeniens verstanden? [Nein]. 2. Welche Identitäten werden durch die Wahl des Russischen in Armenien konstruiert (inszenierte und perzipierte Identität)? [Russlandassoziierte Identitäten, hoher Bildungsgrad, bestimmte Berufsgruppen, fortgeschrittenes Alter]. 3. Gibt es Tendenzen und Perspektiven zum Erhalt bzw. zur Weiterentwicklung des Bilinguismus Armenisch-Russisch in Armenien? [Ja].
\end{abstract}

Schlagworte: Armenisch, Ostarmenisch, Russisch, Bilinguismus, Sprachpolitik, postsowjetische Länder, kulturelle Identität

Keywords: Eastern Armenian, Russian, bilinguism, language politics, post-soviet countries, cultural identity

\section{Historical background}

Armenian is the language of an ancient civilization with a great tradition and culture of writing. The Armenian language, script and literature have always been fundamental for the self-image of Armenian society. Armenian has its own script which 
was developed at the beginning of the 5th Century by Mesrop Mastoc', probably on the basis of - or at least in the order of - the Greek alphabet. The Armenian alphabet was designed according to the specific needs of the Armenian language; hence, it maps the phonological oppositions in Armenian more closely than the Latin and Cyrillic alphabet do for the modern European languages. The Armenian language and script has contributed notably to the fact that the consciousness of the Armenian nation has not been lost over the centuries of a history that was marked by foreign rule, displacement, and genocide, reasons for which most of the Armenian people live abroad. Armenian has always been the de-facto main language of everyday life and local self-government of the Armenian settlements in the Middle East. Nevertheless, the age-long lack of statehood has meant that Armenian never reached the status of a full "Ausbausprache" 'autonomous language' (in the sense of Heinz Kloss, cf. Haarmann 2005a). Since the territory of today's Republic of Armenia (the area where Eastern Armenian is spoken) belonged to the Russian Empire and the Soviet Union between 1813 (Treaty of Gulistan) and 1828 (Treaty of Turkmenchay), and 1991 (end of the Soviet Union), Russian took over numerous higher functional domains. These included administrative communication (especially in contacts with the government in Saint Petersburg and Moscow, but also with the neighbouring Caucasian provinces or Soviet Republics: Russian was the lingua franca of interethnic communication in the Soviet Union) and scientific/ academic communication. For many scientific fields, the top levels of university education (doctoral and postdoctoral level) were not available in Armenia; hence, the élite largely received their training in Moscow. This élite then preferred Russian in numerous functional domains also within Armenia. It is true that in the 1920s, Lenin's nationality policy promoted non-Russian national languages in the Soviet Union, and that languages such as Armenian and Georgian, spoken in territories with relatively few Russian native speakers and a strong national élite, benefited in particular from this policy (cf. Pavlenko 2008, p. 6). Nevertheless, Armenian was not codified as the official language of the Armenian Soviet Socialist Republic (cf. Xačatryan 1991, p. 113), and Haarmann (2005b, p. 826) points out: "Im öffentlichen Leben hat keine andere Sprache mit dem Russischen zu keiner Zeit ernsthaft rivalisiert. Mit der Festigung des stalinistischen Zentralismus wurde auch der exklusive Status des Russischen als faktische, aber nicht nominell als solche anerkannte Staatssprache zementiert." ('In public discourse, Russian had no serious rival at any time. With the fortification of Stalinist centralism, Russian became the de-facto state language, although not officially recognized.') Weitenberg (2006, p. 1900) adds that "ambitious parents preferred to send their children to the Russian schools", and not to the Armenian schools. Good command of Russian was often 
even the decisive criterion for professional success in Soviet Armenia (cf. Grigoryan/ Danielyan 2010, pp. 275, 278). Hence, after 1991 the logic of independence required Armenian as the only officially approved language for all domains (Article 1 of the Language Act of 17 April 1993 [cf. Grigoryan/Danielyan 2010, p. 283; see also \$3], adopted by Article 12, identical text in the Armenian constitutions of 1995 and 2003

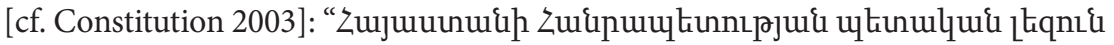
hujteptiqu t:" 'The language of the Republic of Armenia is Armenian.'). The aim of the initially very strict language policy, which Armenia shared with other post-Soviet countries, was the achievement of full 'ausbau' status for Armenian. Although Haarmann (2005a, p. 247) attributes remarkable success to such languages as Estonian, Latvian, Armenian or Georgian in their intent to achieve this status, the Armenian authorities changed their language policy a few years later and substituted the initial one-language policy with a more differentiated framework. ${ }^{1}$ Russian was then allowed to preserve some former domains, for the following reasons:

a) The old academic élite, with its Russian education and its preference for the Russian language, did not simply disappear in 1991, but continues to occupy important positions in society.

b) Armenian non-fiction literature and technical terminology cannot be created overnight. It is a process that takes at least decades. This process is hindered - apart from the fact that Russian terminology and non-fiction literature is available (Russian books and journals in the Armenian libraries) - by the emergence of English as the global lingua franca (cf. Haarmann 2005a, p. 247 and Schulze 2002, p. 898). In a time when established and internationally widespread languages such as German are under pressure by English even within Germany (as is the situation in academic contexts and internationally operating enterprises), the ex-novo creation of communicative practice in these domains for a small language like Armenian is, to put it cautiously, an ambitious project. The Armenian authorities are aware of this and admit Russian, for practical reasons, again in domains which were officially closed to Russian in the first phase after independence (cf. Pavlenko 2008, pp. 19, 28).

c) In contrast to the situation in other former Soviet Republics (e.g., Baltic States or Georgia), in Armenia there is no essential hostility towards Russia (cf. Grigoryan/Danielyan 2010, p. 289). On the contrary, there are very close contacts with Russia. 73 \% of our informants agree with the statement "Russia is Armenia's big brother" (see $₫ 5$ ). Russia supported Armenia in the Nagorno-Karabakh

1 The protection of minority languages in Armenia is considered exemplary for the former Soviet Union, cf. Pavlenko 2008, p. 30. 
war and provides border control assistance at the borders with Turkey and Iran (the Russian Army is present in Armenia with a motor rifle division and an air force group, see also $\$ 5$ and Fig. 4). Moreover, Russia is the main destination of the Armenian labour migration: there is a large Armenian diaspora in Russia, and there are also close economic relations. A small but significant symbol of the close relationship between Armenia and Russia are the non-stop flights from Yerevan Zvartnots International Airport: by 1 July 2013, there were 24 scheduled flights, ten of which went to Moscow and six of which landed in other cities within the Russian Federation (in addition, there was one flight each to the predominantly Russian-speaking CIS capitals Minsk [cf. Giger/Sloboda 2008, pp. 44-45] and Kiev [cf. Bilaniuk/Melnyk 2008, pp. 85-86]).

Therefore, today's education system tries to implement a three-language policy, with Armenian as official language, Russian as the second obligatory language ${ }^{2}$ and another foreign language, usually English, but alternatively also German and French (Pavlenko 2008, p. 18).

\section{Questions}

Russian is still widely used in Armenia, with most speakers exhibiting bilingualism with Eastern Armenian and Russian ${ }^{3}$ - an exception are the so-called Western Armenians, who recently moved to the Republic of Armenia from the Middle East or the other non-Russian-speaking diaspora. Usually they are also bilingual, but with language pairs such as Western Armenian-English, Western Armenian-French or Western Armenian-Arabic; hence, they do not speak Russian. ${ }^{4}$ Conversely, there are also ethnic Armenians from Azerbaijan who have

2 According to Martirosyan 2003, p. 61 (quoted from Grigoryan/Danielyan 2010, p. 290) Russian occupies in the Armenian school system "своеобразное положение между родным, т.е. армянским, и иностранными языками”; i.e., 'a particular position in between the mother tongue, i.e. Armenian, and the foreign languages'.

3 Keep in mind that bilingualism only in rare cases means complete mastery of both languages on the same level. There are many different constellations and, hence, different types of bilingualism, cf. on this point Mackey 2005, pp. 1486-1487 and passim. According to Lazumova 2010, p. 119 about 70 \% of the Armenian population has 'communicative skills' in Russian. For Grigoryan/Danielyan 2010, p. 278 real bilingualism is limited to the cities. According to our personal observation and comparison the degree of active command of Russian in Armenia is lower than, e.g., in the Ukraine, cf. also Bilaniuk/Melnyk 2008, pp. 72-73.

4 Eastern and Western Armenian show differences on all grammatical levels, and the lexical differences are so important that they justify a dictionary with 380 pages 
come to the Republic of Armenia during the Nagorno-Karabakh war and speak Russian, but no or only very little Armenian (Weitenberg 2006, p. 1900). That aside, Armenia is characterized by a strong national consciousness for which the Armenian language plays a major role. Because of this complex situation, it is unclear how to characterize the general attitudes towards Russian in today's Republic of Armenia. Thus, the question arises: what role does Russian play for (staged and perceived) identity construction, and what factors control the language choice between Armenian and Russian. There are no modern surveys on these issues. However, because of the aforementioned ( $\$ 1,[c])$ close relationship of Armenia with Russia, the situation is likely to be different from better-surveyed areas like Georgia or the Baltic States (see $\$ 3$ ). From the many possible questions on language choice and language attitudes, we selected the following key questions which will be answered by interpreting the data from our sociolinguistic questionnaire $(\$ 4-6)$ :

1. Do Armenians perceive Russian as a legitimate second language of Armenia, or exclusively as the language of Russia?

2. Which identities are constructed by the choice of Russian in Armenia (staged and perceived identity)?

3. Are there tendencies to maintain or further develop Armenian-Russian bilingualism in Armenia?

\section{State of research}

We are not aware of modern surveys on language-choice and language-attitude issues in the Republic of Armenia. The language situation in Armenia (linguistic and ethnic groups, bilingualism, etc.) is sketched in general descriptions of Armenian (e.g., Weitenberg 2006; Schulze 2002; with respect to the situation in Soviet times Comrie 1981, pp. 179-183). In numerous articles, Haarmann treats the relationship between Russian and the national languages in the former Soviet republics, its independent successor states and in the (former) Eastern European vassal states including Finland (e.g., Haarmann 2004a, 2004b, 2005), but Armenia is only briefly considered at the periphery. The volume edited by Pavlenko (2008) is a comprehensive description of multilingualism in the former Soviet Union (including countryspecific figures for the groups of speakers and their competence in Russian and in the national languages). However, only Pavlenko herself briefly describes the

(Sak'apetoyean 2011). The issues which arise from this contrast cannot be discussed here. This contribution is on Eastern Armenian only. 
situation in Armenia in her introductory contribution (Pavlenko 2008, pp. 18-22), though there is no country-specific chapter on Armenia. Maybe this is because of the degree of national and linguistic homogeneity in Armenia, which is unusually high for a country of the Middle East and the former Soviet Union. Pavlenko (2008, p. 10) reports that $97.7 \%$ of the population are ethnic Armenians, with ethnic minorities playing little to no role. Hence, Russian is not necessary for interethnic communication in Armenia. This is an important difference from neighbouring Georgia, where large and compactly settled minorities (including Armenians in the region of Samtskhe-Javakheti on the border with Turkey and Armenia) have such limited command of Georgian that administrative communication must be carried out in Russian (Pavlenko 2008, pp. 20-21). Perotto (2003, 2006, 2008, 2014) also examines the relationship between Russian and national languages in Russia, and the other successor states of the former Soviet Union, with a particular focus on Georgia. In Perotto (2014), the particular Armenian situation is illustrated by contrasting it with Georgia and Azerbaijan. In the Georgian education system, Russian has been replaced by English as the primary second language. In Azerbaijan, the younger generations are becoming less familiar with Russian also due to the fact that the Azerbaijani language officially transitioned from Cyrillic to Latin script (see Perotto 2014, p. 169). In Armenia, Russian officially remains the 'second language' (not a 'foreign language'), before English and other foreign languages, and the interest in Armenian-Russian bilingualism is 'real' (Perotto 2014, p. 168). A similar position is taken by Chruslov (2006, pp. 143-145), who first points out that the Armenian language policy since 2001 recognized Russian as an important supranational means of communication (especially for contact with Russia as business partner and as a main destination of labour migration). These factors served to consolidate the position of Russian in the education system. Second, he highlights the role of the Armenian diaspora in Russia, which is engaged in promoting Russian in Armenia (especially by strengthening Russian language teaching at school) (Chruslov 2006, p. 144). Lazumova (2010, pp. 119-121) focuses on the commitment of Russian educational institutions for the promotion of the Russian language in Armenia (e.g., by the Pushkin Institute, by branches of Russian universities in Armenia, and especially by the Russian-Armenian University [Российско-Армянский (Славянский) университет] in Yerevan). Probably the most complete contribution on the position of Russian in Armenia is Grigoryan and Danielyan (2010), who reconstruct in details the stages of Armenian language policy after independence. The first stage involved the attempt to establish Armenian as the only language of the Republic of Armenia. Article 1 of the Language Act of 17 April 1993 states: “Государственный язык Республики 
Армения - армянский, который обслуживает все сферы жизни республики. Официальный язык Республики Армения - литературный армянский язык” 'The state language of the Republic of Armenia is Armenian, which is used in all areas of life of the Republic. The official language of the Republic of Armenia is the Armenian literary language' (Grigoryan/Danielyan 2010, p. 283). This is also the reason why the small remaining number of purely Russian-speaking schools is attended exclusively by students with non-Armenian nationality (cf. Grigoryan/ Danielyan, p. 291). The attempt to suppress Russian in public life has, however, proven to be infeasible for practical reasons. For example, the dubbing or subtitling of all television programmes in Armenian, required by the Broadcasting Act of 20 November 2000, was impossible for financial reasons (cf. Grigoryan/ Danielyan 2010, p. 296). Russian, therefore, is entrenched today in Armenia's language landscape due to its importance in numerous functional domains (the table in Grigoryan/Danielyan 2010, p. 302 shows the proportions of the two languages broken down by functional domains).

\section{Data and method}

The main survey was carried out in May 2013 in the form of an interview, in which students of the State Engineering University of Armenia answered on mainly closed-ended questions. The interviews were conducted in Armenian. We developed the questionnaire in a series of preliminary studies at Yerevan State Linguistic University: starting from open conversations going through standardized interviews with open-ended questions, we arrived at a questionnaire with 28 , partially subdivided closed-ended questions with answer alternatives on nominal and ordinal scales. This enabled quantitative, and in some cases statistical analyses. In addition to questions regarding characteristics of informants (social data, native language of the informants and the parents, family language, self assessment of language skills in Russian and English etc.), questions were asked on attitudes (enjoyment of speaking Russian, relationship between Armenia and Russia), convictions and beliefs (stereotypical speakers of Russian, evaluation of the importance of Russian for career and personal life, importance of Russian in comparison to English) and behaviour (own active and passive use of Russian, including the transmission of Russian to their children) (for the question typology cf. Schnell et al. 2011, pp. 319-333). The questionnaire provided fields for comments beyond the answer alternatives and a 'don't know' category (cf. Schnell et al. 2011, p. 330) in order to not force informants to take a position with respect to topics for which they do not have a position. 
Informants: the population was the totality of the students of the Faculty of Computer Systems and Informatics of the State Engineering University of Armenia $(\mathrm{N}=779)$. From a numbered list (1-779) of the students, we have drawn a random sample of 40 students using a Linux shell script (function \$RANDOM). Of the 40 drawn students, 37 were available for the survey. The mean age was 20 years, the gender distribution was 10 (female) to 27 (male). We preferred students from the State Engineering University to the students of our own Linguistic University, because a) at the Linguistic University the students are almost exclusively female, $b$ ) these female students have - evidenced by their choice of languages as a course of study - a special interest in languages in general, and maybe in Russian in particular. This interest seemed counter-productive to our goals, and c) the students of the State Engineering University - according to our opinion - better reflect today's typical educated, urban, modern and success-oriented youth of Armenia, about which we wish to make statements. ${ }^{5}$

Method: depending on the type of question, we calculated the arithmetic mean ${ }^{6}$ and/or visualized the distribution of the answer alternatives in the form of bar charts. For selected phenomena, statistical correlations were examined: in these cases we interpreted nominal scales as ordinal scales. ${ }^{7}$ Generally, we interpreted the results in terms of their content and applied them to the key questions identified in $₫ 2$.

\section{Results}

In this paragraph, we present the results of the questionnaire analysis. The discussion and application of the results on the key questions of $\$ 2$ take place in $\$ 6$.

The first group of variables relate to the native language (of the informant [see Fig. 1], of the father and of the mother). It turns out that almost all informants indicate Eastern Armenian as their native language. 'Native language' or 'mother tongue' is a controversial concept. The 'native language' is usually characterized

5 For the authorization of the survey and help in the preparation we would like to thank the Rector of the State Engineering University, Prof. Ara Avetisyan.

6 Strictly speaking, the calculation of the arithmetic mean of ordinal-scale values is not a valid statistical method. However, since it is debatable whether in the social sciences the interval scales, in principle necessary for the determination of the mean, do exist at all, we adopt the widespread practice to accept a risk of error which does exist but is manageable due to the simplicity of the variable. Cf. on this point Schnell et al. 2011, pp. 137-141.

7 This method is, strictly speaking, also not admissible. But according to our point of view the results are nevertheless valid, again because of the simplicity of the variables. For statistical calculations we would like to thank Prof. Alfred Lameli (Research Centre Deutscher Sprachatlas, Philipps University Marburg). 
by the fact that - in terms of language acquisition - it is the first language, and that the speakers have higher language skills in this language than in other languages; additionally, speakers have an emotional bond to their 'mother tongue' (cf. Dietrich 2004). Considering the additional comments of the informants, the indication of both Russian and Armenian as mother tongues is based on the fact that these informants attended a Russian (i.e., completely Russian-language) school in Armenia. The only informant who selected Russian as the only mother tongue (not Armenian) lived in Russia for ten years. Given this distribution, i.e. almost only Armenian native speakers, it is surprising that as many as $19 \%$ of the informants indicate Russian as family language. Figure 1 contrasts the numbers of native and family language. Two informants select Russian even as the only family language, although none (neither the informants themselves, nor father or mother) are Russian native speakers. From the comments and the information concerning school education (Russian or Armenian school), we conclude that Russian as a family language depends on the type of schooling: with one single exception, in which both parents were categorized as native Russian speakers, the indication of 'Russian as family language' correlates with the Russian school attendance of at least the parents, and sometimes of the informants themselves. Russian as family language is, thus, a conscious choice, depending on the type of education. The correlation of Russian with a high level of education is confirmed by the observation that 'educated' is a very common stereotype for speakers of Russian (see below).

Language skills (Fig. 2). All informants learned Russian at school, with at least two to three hours per week (this result confirms the numbers in Pavlenko 2008, p. 18). Additionally, the university curricula of all informants included two semesters of Russian. This means that most informants attest to having 'advanced' or 'good' language skills (value 3 on the scale from 0 'zero' competence to 4 'nativelike' competence in Fig. 2). Consequently, the answer 'zero' is not given at all: all informants have Russian language skills. The mean value of Russian competence is 2.89. With English, the situation is different. The mean value of competence is 2.35 and, thus, significantly lower than the mean value of Russian. One informant claims to have no English skills at all. The result matches expectations: Russian remains the second obligatory language in the Armenian education system (unlike in Georgia, see $₫ 3$ ), and literature for the study of Computer Science is available in Russian, if not in Armenian.

Another explanation for the strength of Russian can be found in the contact with Russia and other post-Soviet countries, which are at least partially Russianspeaking. Almost all informants indicate having relatives or friends in Russia, at least one third of the informants lived in Russia from a few months to several 
years. From the answers to the question regarding contacts with foreign countries, we conclude that the relationships are not limited to the Russian-speaking countries. Almost $80 \%$ of the informants (28 informants) specify contacts to other countries, particularly to the United States (12) and Germany (7) (only two informants to France). Nevertheless, the relationship with the Russian-speaking countries is by far the closest one (on this point see also the statements in $\$ 1,[c]$ ).

Attitudes. The first variable concerns the enjoyment in speaking Russian. Fig. 3 shows that the informants like to speak Russian (mean value 2.84 on an intensity scale from 0 'not at all' to 4 'very much'). Especially women responded that they liked Russian, with six out of ten female informants selecting the maximum value 'very much'. The comparison with the self-assessment of language skills in Russian (Fig. 2) shows a significant correlation between the degree of Russian language skills and the degree of enjoyment of speaking Russian: the higher the skills, the more the informants like to speak Russian $(\mathrm{p}<0.05, \mathrm{~N}=37$, two sided; $\mathrm{RHO}=$ 0.411 ). The other two variables in this group relate to (socio-)political attitudes. $73 \%$ of the informants attest to the statement "Russia is Armenia's big brother", a confirmation of the close relationship and a positive assessment of this relationship (as already stated in $₫ 1,[c]$, above). Hence, the controversial evaluations of the presence of Russian Army in Armenia visualized in Fig. 4 are surprising at first glance. First, it seems surprising - given the good and close relationship with Russia - that the rejection of the presence ('undesirable' and 'very undesirable') by 15 informants is only a little lower than the endorsement ('desirable' or 'very desirable') by 20 informants. Second, and this is even more revealing, Fig. 4 shows a bimodal distribution in which the average value (2 'all the same') is virtually not selected. This means that the presence of the Russian Army in Armenia polarizes the informants: the informants are either in favour of the presence or against it, but almost no one is indifferent to this question. This fact plays a major role in answering the key question 1 in $\$ 6$.

Conviction issues. For the first variable, the question "Who speaks Russian in Armenia?", we derived the following possible answer stereotypes for speakers of Russian from our preliminary studies: 'old', 'young', 'prostitute', 'educated', 'foreigner', 'beggar', 'rich'. Clear correlations exist with the stereotypes 'old' (confirmed by $90 \%$ of informants) and 'educated' ( $95 \%$, not a single 'no', only two informants answer 'don't know'). For the other suggested stereotypes we obtained no clear results. However, in addition to our suggestions, many informants specified 'teachers' and 'doctors' as typical speakers of Russian in Armenia. The second variable relates to the evaluation of the concrete meaning of Russian in life. All informants $(100 \%)$ consider Russian 'important/useful'. There are small differences 
with respect to the functional domains: whereas $97 \%$ of the informants (36 of 37 informants) consider Russian 'important/useful' for 'study/science', and $95 \%$ for 'work/job', "only" $78 \%$ of the informants share this evaluation for 'leisure'. However, the difference between the domains is small. Fig. 5 visualizes the assessment of the importance of Russian in comparison to English. Most informants (54 \%) believe that both languages are equally important, only three informants consider Russian to be more important than English. A closer look shows two more results. First, if the variable is conceived as constituting an ordinal scale ('English more important' -1, 'both equally important' 0 , 'Russian more important' 1; see Fig. 5) then there is a (negative) significant correlation with the self assessment of English language skills (see Fig. 2), namely: the higher the competence in English, the more English is rated as more important than Russian ( $\mathrm{p}<0.05, \mathrm{~N}=37$, two sided; RHO = -0412). Second, women consider English to be more important than Russian. One half of the female informants take both languages for equally important, the other half think that English is more important; none of the women consider Russian to be more important than English (see Fig. 5).

The last group of variables are self-assessments of language behaviour. The answers to the question "How often do you speak Russian?" lead to a mean value of 2.43 on a scale from 0 'never' to 4 'always', i.e., between 'sometimes' (2) and 'often' (3), with no informant speaking 'never' and five informants speaking 'always' Russian. The question regarding the contact groups reveals that only 'Russians' are typical interlocutors for almost all informants (95\%). But we obtained a notable proportion of positive answers also to the other contact groups we proposed: 'foreigners not from Russia' (35\%); 'friends' (46\%); 'university' (22 \%); 'family members' (35\%). Additionally, the vast majority of informants consumes Russian mass media: $92 \%$ of the informants state that they regularly watch Russian television (which can be viewed everywhere in Armenia) or listen to Russian radio news.

The final variable is the question of the transmission of Russian to the informants' (future) children. Fig. 6 shows that the informants here have no common position. The number of 'don't know' responses here is higher than in any other matter. However, the comparison with other variables reveals a correlation with their Russian language skills (the Russian language skills are better in informants who answered 'yes' to the question "Would you speak Russian to your children?"), and in particular with the family language (see Fig. 1). All informants who specify both Russian and Armenian as a family language want to transmit Russian to their own children. (The two informants who indicated only Russian as a family language selected 'don't know' and 'yes'.) Conversely, contact with Russia does 
not seem to play a role: informants with 'yes' and 'no' answers have relatives or friends in Russia to the same extent.

\section{Discussion and conclusions}

The single results presented in $\$ 5$ will be related to the key questions of $\$ 2$ in the following discussion.

1. Do Armenians perceive Russian as a legitimate second language of Armenia, or exclusively as the language of Russia?

The question aims to clarify whether Armenians use Russian to construct their own Armenian identities, or whether the use of Russian constitutes foreign, Russia-related (in the sense of "российский", not "русский”) identities. Our data suggest that Russian is not conceived as being a proper language of Armenia, i.e., Russian is used to construct identities that are not properly 'Armenian'. Our data provide the following arguments for this position:

a) There are virtually no native speakers of Russian in Armenia (Fig. 1). The results for our population can be generalized for the total of the Armenian population (Perotto 2003, p. 29 reports $1.6 \%$ of ethnic Russians in Armenia, Pavlenko 2008, p. 10 only $0.5 \%$ for 1999-2004). This constitutes a very different situation from that in Ukraine; for example, where 1999-2004 29.6\% of the population are native speakers of Russian (Pavlenko 2008, p. 10); in 1989 as much as $71.7 \%$ of the Ukrainian population report speaking Russian fluently, cf. Pavlenko 2008, p. 15), although there was officially a one-language policy with Ukrainian as the only language until the Language Act of 2012 (which in principle gives any minority language official status if certain requirements are fulfilled, but which aims, in fact, at promoting Russian).

b) The answers to the questions on attitudes revealed positive attitudes towards Russian and Russia (see Fig. 3), but at the same time the community is polarized regarding the presence of the Russian Army (Fig. 4). In our opinion, this polarization shows a clear consciousness of the distinction between 'one's own', 'Armenian', and the 'foreign', even if the foreign aspects are positively evaluated. We want to relate these socio-political assessments on the linguistic level, and conclude that the symbolic function of the expression of Armenian identity can be fulfilled only by the Armenian language (cf. Perotto 2008).

c) The fact that English is considered, in total, more important than Russian (Fig. 5) suggests that English and Russian compete as linguae francae for international communication. If Russian would be regarded as an expression of 
Armenian identity, it would probably not be rated lower than English, despite its minor importance as a lingua franca. ${ }^{8}$

2. Which identities are constructed by the choice of Russian in Armenia (staged and perceived identity)?

With the selection of Russian in Armenia, somehow 'foreign', 'Russia-related' (российский) identities are constructed. Armenians consciously adopt these identities in certain situations. Vandermeeren (2005, p. 1319) points out that "speakers can be subjectively committed to an ethnolinguistic group membership which is - objectively speaking - not theirs. Group consciousness moves between the two poles of group membership: objective group membership (e.g. by birth) and subjective group membership (by choice)". The question "Who speaks Russian in Armenia?" shows a set of stereotypes for this foreign identity. In sum, Russian is associated with certain professional groups and, generally, a high level of education. According to Joseph (2010, p. 17, following Silverstein 2003), certain forms of speech are primarily associated with a real or perceived region of origin of the speaker, in the second place with the level of education ("second order' indices of ideologically loaded information, such as the eliteness of a speaker's education"). Joseph's concern is regional varieties (of English). However, we think that the concept also fits quite well for the situation 'Russian in Armenia'. The professions 'teacher' and 'doctor', specified by the informants as identifying typical speakers of Russian in Armenia, imply prototypical Russiarelated identities. Many members of these professional groups, who belong - in the classical understanding - to the educated élite, were trained during Soviet times in Russia. Even in today's training of these professions in Armenia, mainly Russian literature is used. Doctors in Armenia continue to prefer Russian to Armenian in their technical communication. Answers to the questions regarding the functional domains show that Russian is considered a little less important for leisure in comparison to study/science and work/job. However, Russian still retains notable importance in the leisure sector, according both to the informants' data and our observation of language choice in social media such as Facebook. The association of Russian with a high level of education - and of the national language with simplicity and clear national symbolism - is typical for many successor states of the Soviet Union. In the Ukraine, Ukrainian is widely regarded as 'provincial' and 'rural'. Nevertheless, the Ukrainian language is a symbol of

8 Aronin/Singleton 2012, pp. 137-138 depict a "hierarchy of languages" in which Russian (alongside with, e.g., German) is one of worldwide 12 "supercentral languages" whereas English is the only "hypercentral language". 
national consciousness of such importance that even Kievan russophones try to improve their Ukrainian language skills in order to dissociate themselves from Moscow, and modern pop culture is increasingly staged in Ukrainian (Bilaniuk/ Melnyk 2008, p. 86). In Belarus, the use of Belarusian is even almost limited to this symbolic function. Belarusian is losing its prominence even in the countryside, in favour of Russian (Giger/Sloboda 2008, p. 46).

3. Are there tendencies to maintain or further develop Armenian-Russian bilingualism in Armenia?

Schulze (2003, p. 898) believes that in the medium term, "das Armenische in der Republik trotz aller Fördermaßnahmen im Erziehungswesen und in Bezug auf die öffentlichen Medien hinter dem Russischen, jetzt verstärkt auch dem Englischen als Mittel des öffentlichen und politischen Diskurses zurückbleiben wird" ('In the Republic of Armenia, Armenian will fall behind Russian, and nowadays also English, as means of public and political discourse, despite all support measures in education system and public media'). We are of the opinion that this situation at the moment is not yet in sight. However, above all we advocate a perspective that does not interpret the linguistic situation in Armenia as a language battle. Armenian-Russian bilingualism (enriched by English in particular functional domains) is rather an important resource of the Republic of Armenia at the crossroads of Europe, Russia and the Middle East. (In many post-Soviet countries, the positive evaluation of bi- and multilingualism as a valuable resource is not yet shared by certain national élites that consider the use of Russian a threat to the development of the national languages; cf. on this point Pavlenko 2008, pp. 32-33.) Our data supply two arguments in favour of the opinion that Armenian-Russian bilingualism in Armenia could evolve in a positive manner (cf. the similar position in Perotto 2014, p. 168). First, there is a widespread positive attitude towards the Russian language: people like to speak Russian (Fig. 3). Russian is especially popular among young women, who are decisive for the transmission of the language in the family. Second, Russian is the family language in a notable number of cases, although it is rarely specified as a native language (19\% of the informants indicate [not only, but] also Russian as a family language; Fig. 1). Such families also generally intend to pass Russian to their own children (cf. Fig. 6). This is not the case for English; hence, in the medium term it is not expected that English in Armenia will acquire a position which is beyond the - obviously remarkable and increasing - importance as global lingua franca (the situation in Georgia is different, see $\$ 3$ ). It is true that there is a significant reduction in Russian language skills as compared to Soviet times (cf. Grigoryan/Danielyan 2010, p. 287), a fact that in our opinion threatens the status of Russian as language of science (contrary 
to Grigoryan/Danielyan 2010, p. 301 who believe: "Русский язык продолжает оставаться языком науки." 'Russian remains the language of science.'). On the other hand, Russian could get new support by a potential - although politically very controversial - customs union between Russia and Armenia, which was negotiated in autumn 2013. Chruslov (2006, p. 145) summarizes: “Применение [русского] языка в качестве эффективного средства межнационального общения и мирового языка неставится под сомнение.' 'The use of Russian as an effective means of interethnic communication and as a world language is not in doubt.'

Note: In the context of the ongoing conflict in Ukraine (Spring 2014), the authors wish to point out that the recognition of the importance and usefulness of Russian in the post-Soviet countries does not constitute a justification for illegal territorial claims of the Russian Federation (e.g., annexation of Crimea).

\section{References}

Ammon, Ulrich/Dittmar, Norbert/Mattheier, Klaus J./Trudgill, Peter (eds.): Sociolinguistics/Soziolinguistik. 2nd completely revised and extended edition. 3 vols. (HSK 3.1-3.3.). De Gruyter: Berlin/New York 2004-2006.

Aronin, Larissa/Singleton, David: Multilingualism. Benjamins: Amsterdam/Philadelphia 2012.

Bilaniuk, Laada/Melnyk, Svitlana: "A Tense and Shifting Balance: Bilingualism and Education in the Ukraine". In: Pavlenko (ed.) 2008, pp. 66-98.

Bucholtz, Mary/Hall, Kira: "Locating Identity in Language". In: Llamas/Watt (eds.). 2010, pp. 18-28.

Čelyšev, Evgenij P. (ed.) = Челышев, Евгений П. (ред.): Решение национальноязыковых вопросов в современном мире. Страны СНГ и Балтии. [Resolution of national-language questions in the modern world. CIS and Baltic States.] Российская академия наук: Москва 2010. [Russian Academy of Sciences: Moscow 2010].

Chruslov, Georgij = Хруслов, Георгий: “Функционирование русского языка в странах СНГ" ["Functions of Russian in the CIS"]. Russian Language Journal 56, 2006, pp. 131-166.

Comrie, Bernard: The Languages of the Soviet Union. Cambridge University Press: Cambridge 1981.

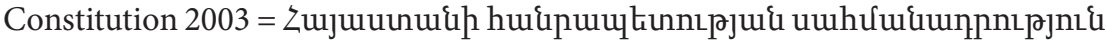
[The Constitution of the Republic of Armenia], Eplumi, 2003, Shqpuid Utid: [Yerevan: Tigran Mec 2003]. 
Dietrich, Rainer: "Erstsprache - Muttersprache". In: Ammon, Ulrich et al. (eds.), vol. 1, 2004, pp. 305-311.

Giger, Markus/Sloboda, Marián: “Language Management and Language Problems in Belarus: Education and Beyond”. In: Pavlenko (ed.) 2008, pp. 41-65.

Grigoryan, E. A./Danielyan, M. G. = Григорян, Э. А./Даниелян, М. Г.: "Состояние общественных функций русского языка в современной Республике Армения" ["Social functions of Russian in the modern Republic of Armenia”]. In: Čelyšev (ed.) 2010, pp. 275-303.

Haarmann, Harald: "Abstandsprache - Ausbausprache". In: Ammon, Ulrich et al. (eds.), vol. 1, 2004a, pp. 238-250.

Haarmann, Harald: "Geschichte der Anwendungen der Soziolinguistik". In: Ammon, Ulrich et al. (eds.), vol. 1, 2004b, pp. 818-836.

Haarmann, Harald: "Linguistic Barriers between Speech Communities and Language Choice in International Contacts". In: Ammon, Ulrich et al. (eds.), vol. 2, 2005, pp. 1521-1535.

Joseph, John E.: “Identity”. In: Llamas/Watt (eds.) 2010, pp. 9-17.

Lazumova, M. N. = Лазумова, М. Н. : “О функционировании русского языка в государствах СНГ и Балтии" ["About the functions of Russian in the CIS and the Baltic States"]. In: Čelyšev (ed.) 2010, pp. 113-144.

Llamas, Carmen/Watt, Dominic (eds.): Language and Identities. Edinburgh University Press: Edinburgh 2010.

Mackey, William F.: "Bilingualism and Multilingualism”. In: Ammon, Ulrich et al. (eds.), vol. 2, 2005, pp. 1483-1495.

Martirosyan S. = Мартиросян, С.: "Русский язык в Армении становится элитарным поневоле" ["Russian unwantedly becomes an élite language in Armenia”]. Институт стран СНГ. Информационно-аналитический бюллетень 41, 2003, p. 61.

Mendoza-Denton, Norma/Osborne, Dana: “Two Languages, Two Identities?” In: Llamas/Watt (eds.). 2010, pp. 113-122.

Pavlenko, Aneta: "Multilingualism in Post-Soviet Countries: Language Revival, Language Removal, and Sociolinguistic Theory". In: Pavlenko (ed.) 2008, pp. 1-40.

Pavlenko, Aneta (ed.): Multilingualism in Post-Soviet Countries. Multilingual Matters: Bristol/Buffalo/Toronto 2008.

Perotto, Monica: "La sociolinguistica in Russia oggi: problematiche e tendenze". Slavia XII/4, 2003, pp. 11-43.

Perotto, Monica: "Politica e pianificazione linguistica nelle repubbliche postsovietiche: il caso georgiano". In: Soziolinguistica y language planning. Atti 
del Convegno Alpes Europa "Soziolinguistica y language planning", Ortisei, 12-14.12.2002. Trento: Regione Autonoma Trentino/Alto Adige 2006, pp. 203-227.

Perotto, Monica: "Il problema dell'identità etnica, civile e linguistica nell'area postsovietica”. In: Baccolini, Raffaella/Leech, Patrick (eds.): Constructing identities. Translations, Cultures, Nations. Bononia University Press: Bologna 2008, pp. 123-139.

Perotto, Monica: "Bilinguismo letterario e politica linguistica nell'area postsovietica: il caso georgiano". In: Montini, Chiara (ed.): La lingua spaesata. Il multilinguismo oggi. Bononia University Press: Bologna 2014, pp. 163-179.

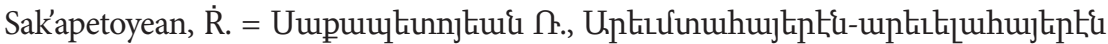
unp pununui [New Eastern-Western Armenian dictionary], Epluuq, 2011, Shqpui Utid: [Yerevan: Tigran Mec 2011].

Schnell, Rainer/Hill, Paul B./Esser, Elke: Methoden der empirischen Sozialforschung. Oldenbourg: München 2011.

Silverstein, Michael: "Indexical order and the dialectics of sociolinguistic life". Language and Communication 23, 2003, pp. 193-229.

Schulze, Wolfgang: “Armenisch". In: Okuka, Milos (ed.): Lexikon der Sprachen des europäischen Ostens. (Wieser Enzyklopädie des europäischen Ostens, vol. 10.) Wieser: Klagenfurt 2002, pp. 891-899.

Vandermeeren, Sonja: "Research on Language Attitudes". In: Ammon, Ulrich et al. (eds.), vol. 2, 2005, pp. 1318-1332.

Weitenberg, Jos: “Armenia”. In: Ammon, Ulrich et al. (eds.), vol. 3, 2006, pp. 1900-1902.

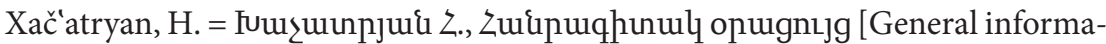

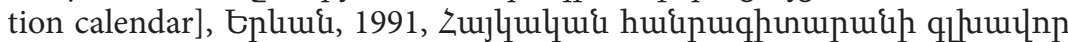
hưfpuqnnıpjnı\{: [Yerevan: Haykakan hanragitarani glxavor xmbagrut'yun 1991]. 


\section{Figures}

Fig. 1: Native language of the informant and family language

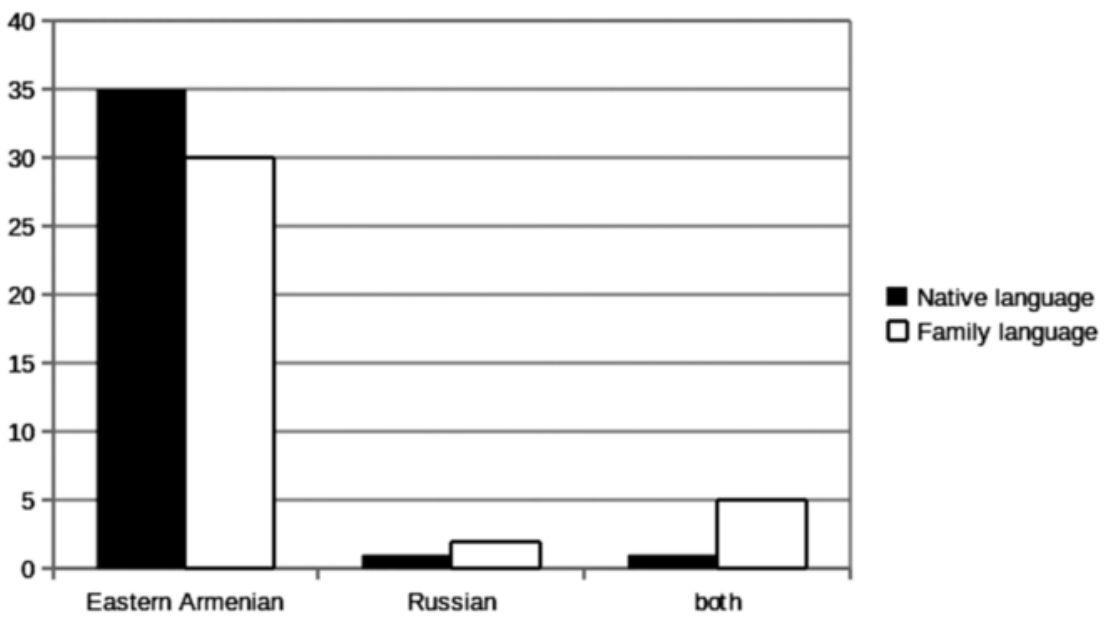

Fig. 2: Comparison of language skills in Russian and English

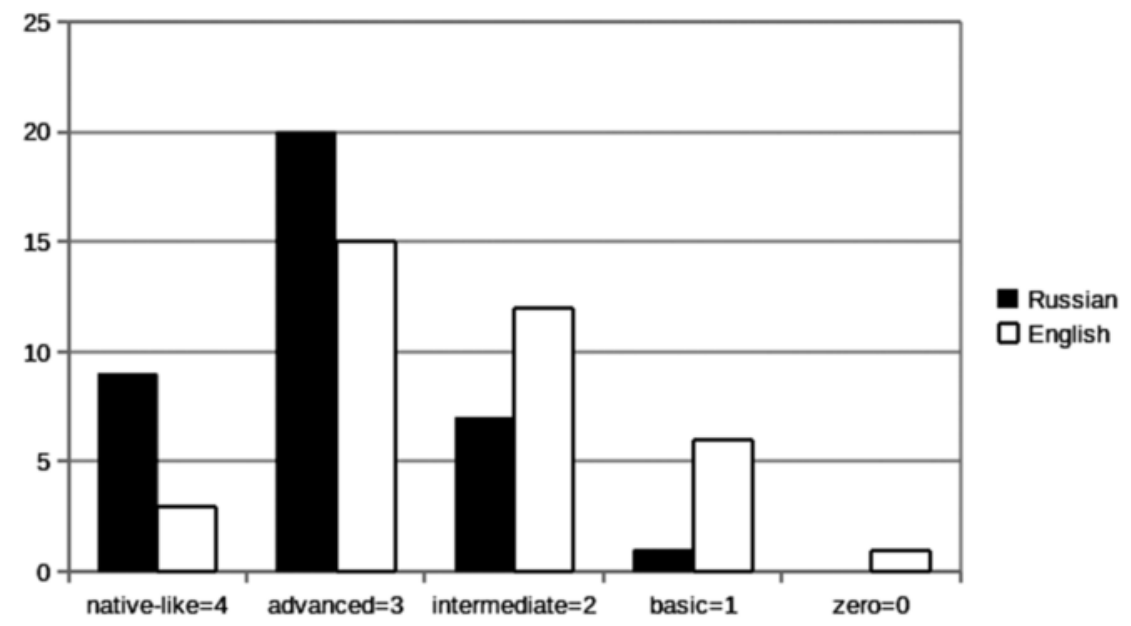


Fig. 3: Answers to the question: "Do you like to speak Russian?"

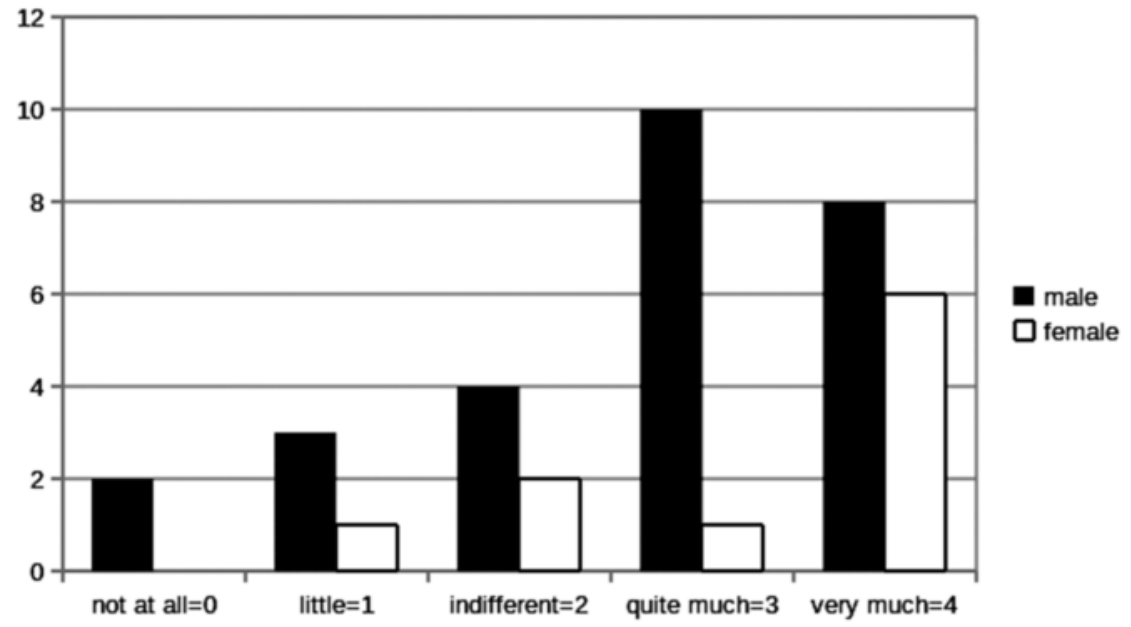

Fig. 4: Assessment of the presence of the Russian Army in Armenia for border security

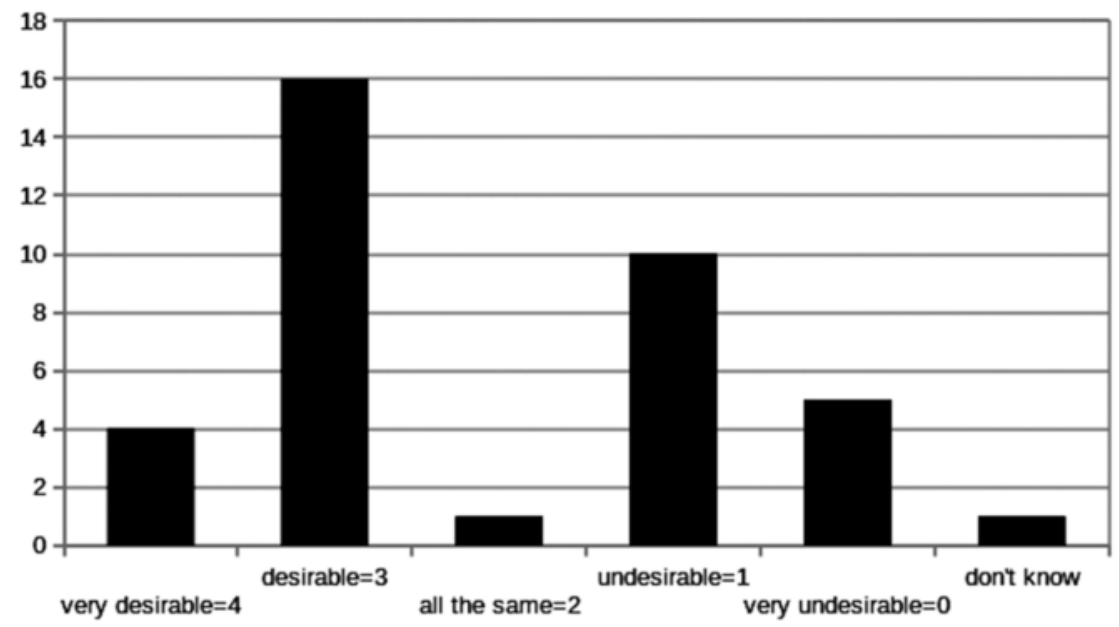


Fig. 5: Evaluation of the importance of Russian in comparison to English

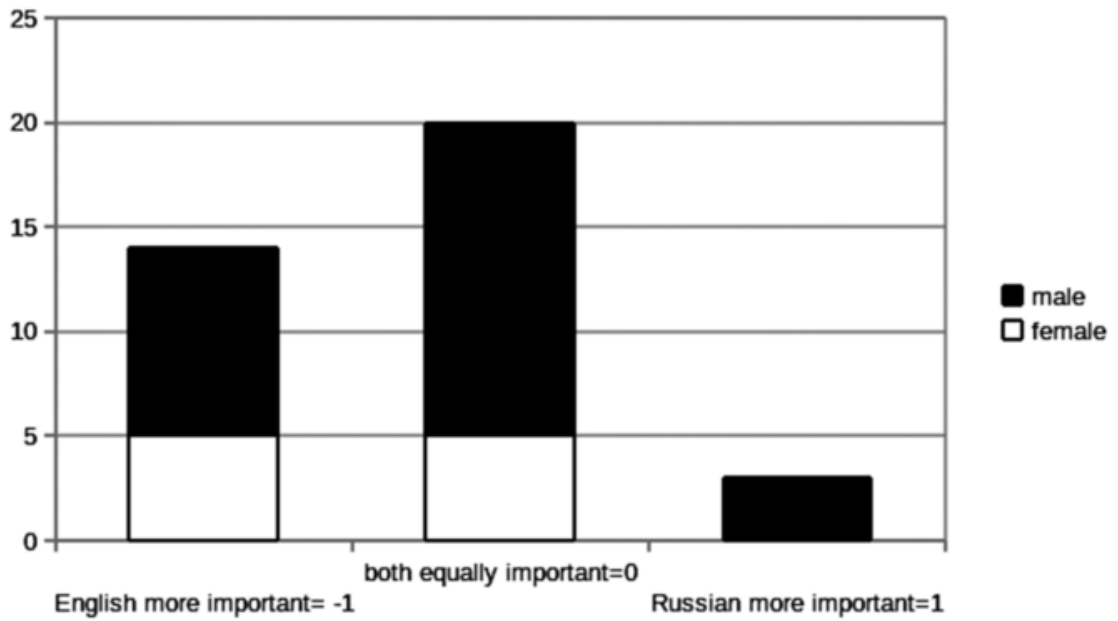

Fig. 6: Answers to the question: "Would you speak Russian to your children?"

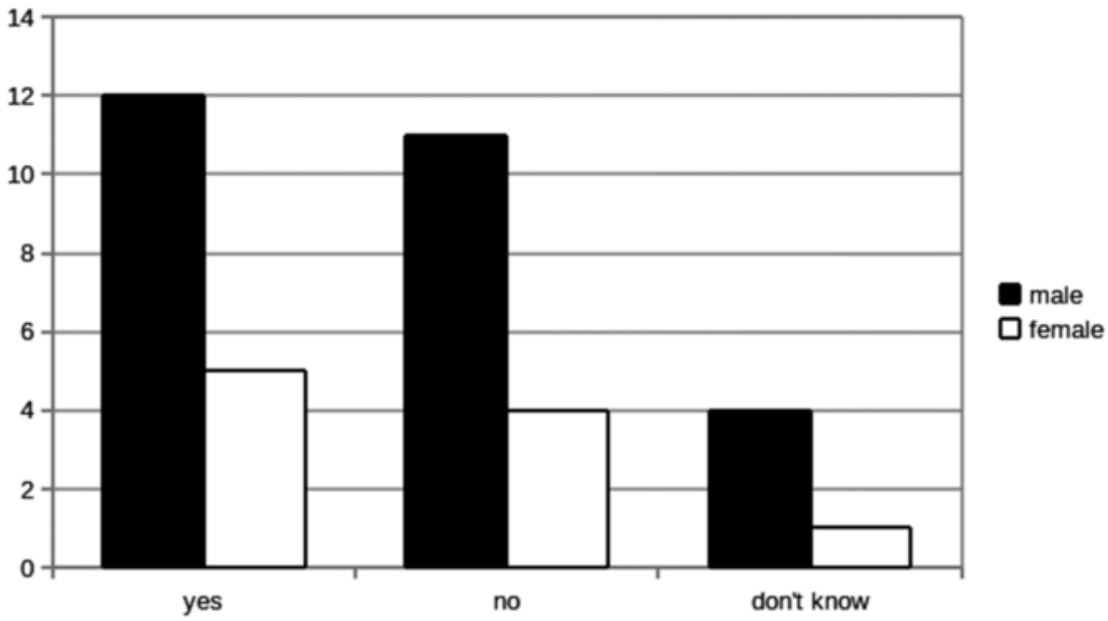


Rita Vallentin

(Frankfurt/Oder)

\title{
Linguistic Strategies of Constructing Durable and Permeable Ethnic Boundaries in a Brazilian Quilombo Community
}

\begin{abstract}
Ethnische Grenzen spielen in Brasilien nach wie vor eine entscheidende Rolle bei der Definition von „In- und Out-Groups“. Dieser Artikel konzentriert sich auf die Konstruktion dieser Grenzen in einer brasilianischen Quilombo Gemeinschaft. Die Quilombolas berufen sich auf ethnische Kategorien wie "Afro-Brasilianisch" und die Bewahrung einer "afro-brasilianischen Kultur" als entscheidende Faktoren für die Zugehörigkeit zu oder Ausgrenzung aus der Wir-Gruppe. Nichtsdestotrotz verlangen soziale Veränderungen im Quilombo eine ständige Verteidigung der etablierten Grenzen und eine Neukonzeption der „wir“- und „die anderen“-Kategorien. (Ethnische) Grenzen, die bisher unüberwindbar und durabel schienen, werden durch diese Veränderungen im sozialen Feld durchlässiger. Basierend auf einem semi-strukturierten Interview mit einer Quilombola stehen die sprachlichen Mittel und Strategien im Fokus der Analyse, die ethnische Grenzen zwischen von der Sprecherin relevant gemachten Gruppen stärken oder abschwächen.
\end{abstract}

Schlagworte: ethnische Grenzen, Durabilität - Permeabilität, linguistische Konstruktion von „wir“- und „die anderen“-Gruppen

Keywords: ethnic boundaries, durability - permeability, linguistic construction of in- and out-groups

\section{The Nature of Ethnic Boundaries}

As shown by the various contributions at the conference on "Linguistic Construction of Social Boundaries" held at the European University Viadrina, Frankfurt (Oder), ethnic boundaries play a crucial role in group formation and the differentiation of a "we" from "others". Practices of making boundaries can be closely associated with "practices of othering" (van Houtum/van Naerssen 2002, p. 125), as boundaries naturally enclose entities, and at the same time exclude others. The fact that boundaries are made underlines that they are socially and/or symbolically constructed (cf. Lamont/Molnár 2002, p. 168), and not a product of an a priori division of the world into different territories and different groups. Ethnic boundaries are a special kind of social boundary, dividing groups along different 
and changing categories of belonging or exclusion. The difficulty starts when we try to define ethnicity, and the boundaries drawn based on this concept. Ethnicity can be seen as a "subjectively felt sense of belonging based on the belief of shared culture and common ancestry" (Wimmer 2008a, p. 973). A perceived shared culture and a common ancestry includes all the features usually connected with the term ethnicity (language, customs, heritage, religion etc.). With his definition of ethnicity as a "subjectively felt sense", Wimmer already indicates that ethnic groups are "not things in the world but perspectives on the world" (Brubaker 2002, p. 174-148). Those perspectives are (re-)produced, altered, negotiated or abandoned by subjects building in-groups or we-groups. The "boundary-making" or "boundary work" based on subjects" "agency" (Wimmer 2008, p. 1027), however, does not only stem from the members of we-groups based on ethnic categories. Recognition of ethnic categories and their acknowledgement from "outside" also define ethnic groups. Hence, it is a simultaneous interplay of self-ascriptions and external ascriptions (Barth 1969, p. 13) which shape the categories of inclusion and exclusion as well as the boundaries around the we-group. It is, according to Barth (1969, p. 15), a question of situational social relevance which categories or features are chosen as the defining ones for in-group membership. Thus, the boundary between "in and out" is defined not by objective criteria, but by what is made relevant as marking ethnicity in the context of a specific situation, by a specific group of people at a specific time. This is why ethnicity itself can be seen as an ongoing "project", as something rising, declining or even failing - not as a static entity, but as a process resulting (or not) in "groupness" (Brubaker 2002).

Taking this constructivist stance towards ethnic boundaries, however, one should not forget that the "cultural stuff" (Barth 1969, p. 15) enclosed by them is not a totally arbitrary "invention" of the subjects themselves. As we will also see in the example of the Brazilian Quilombo in this paper, people return to narratives as guiding frameworks. Boundary-making is embedded into certain social fields (Bourdieu 1993) or, for example, public (political) discourses (cf. van Dijk 1987, Wimmer 2008a). Along these lines, and as Barth himself stated in his revision of "Ethnic groups and boundaries" (1994), the "cultural stuff" a boundary encloses cannot be seen as entirely disconnected from the making of boundaries. It might influence the strategies of boundary making, its shape, and its appearance around the in-group. When we analyze the construction of ethnic boundaries, therefore, we should have a basic understanding of the ethnic group's social linkages, their narratives as well as their placement within social space. 


\section{The Linguistic Construction of Ethnic Boundaries}

If ethnic boundaries are perspectives on the world and "display(s) both a categorical and a social behavioural dimension" (Wimmer 2008a, p. 975) as guidelines for group construction, the question arises how they are constituted. In many cases of ethnic boundary-making, language itself provides the main category of belonging to the "we" or the "other". However, linguistics still come into play when groups are not divided along language lines. Sanders (2002, p. 327) sees ethnic boundaries as "[...] patterns of social interaction that give rise to, and subsequently reinforce, in-group members' self-identification and outsiders' confirmation of group distinctions". The making of an ethnic or any other social boundary as "social mediums" (Sanders 2002, p. 327) are cognitive processes among interacting subjects which can be analyzed via the medium of language. A linguistic approach assures access to empirical data, as language displays a reflection of what people think, and can hence reveal the cognitive processes behind boundary constructions. As already stated, ethnic boundaries - as "social mediums" - are in a constant flux of transmission, alteration or restructuring. These processes are negotiated through interaction. An analytical focus on linguistic means as word forms or discursive practices thus gives an insight into these processes of negotiation.

A linguistic approach to ethnic boundaries also unfolds what is important to people constructing the boundary, as the boundary itself is rendered "problematic" (cf. Hausendorf 2000 , p. 99). The boundary becomes a communicative topic if something about it has to be clarified: in other words, if the two or more interlocutors are not on the same page concerning "sharing of criteria for evaluation and judgement" (Barth 1969, p. 15). Speakers decide on boundaries, membership categories and respective category-bound activities acceptable to the in-group (Sacks 1992), and as other attributions and evaluations are presented as relevant in the course of conversation (cf. Asmuß 2003, p. 109). In doing so, speakers reveal something about the nature of the boundary. This approach is especially fruitful in interview situations featuring a member of the we-group and an outsider as the interviewer. The speaker more often feels the need to explain, legitimize and contextualize the categories of "in and out", as the boundary does not form part of the shared understanding of the two interlocutors.

Finally, the linguistic approach to ethnic boundaries is helpful because we can consider every speech act as an "act of identity" (Le Page/Tabouret-Keller 1985, Tabouret-Keller 1997). With varying discursive means and linguistic forms, speakers display their identities and locate themselves, the groups they belong to and those around in social space. The questions of identification with a we-group and 
social practices of "othering" can thus be pursued with a look at the social realities of the interlocutors and the social positionings they open up in their utterances.

\section{Durable and Permeable Ethnic Boundaries}

In his paper about strategies of ethnic boundary-making, Wimmer (2008, p. 1044) introduces several procedures of shifting or modifying existing boundaries. Depending on their "varying degrees of boundedness" (Wimmer 2008a, p. 976), they can be transformed in more or less radical ways. I will introduce a continuum of boundary qualities: from durable boundaries on the one end, to permeable boundaries on the other. A durable ethnic boundary emphasizes a clear-cut separation of in- and out-groups along certain categories. They can be recognized as 'hard' boundaries - rather static and not easily negotiated and changed by individual subjects (cf. Schiffauer et al. 2012, p. 20 f.). Permeable boundaries, on the other hand, are "selectively permitting passage, i.e. a dual movement of inclusion and exclusion" (Schiffauer et al. 2012, p. 100). Often, these boundaries are the result of on-going negotiation processes regarding demarcations between the "we" to the "other", especially in times of social transformation.

As this paper deals with the linguistic construction of ethnic boundaries, the focus of analysis will be on linguistic means and strategies that either strengthen or mitigate boundaries between groups. When speakers use linguistic means to reinforce boundaries between groups, we can speak of an increase in their durability. On the other hand, linguistic strategies of mitigating or relativizing boundaries can be observed as a move towards a rather permeable quality of the boundary established by the speakers.

\section{The Brazilian Quilombo as a Social Field of Constructing Ethnic Boundaries}

In order to embed the boundary-drawing mechanisms of the interviewees in the existing social setting, a short introduction to the history of the Quilombo Campinho da Independência in Brazil is necessary (see Bourdieu's concept of the field [champ], 1993). Certainly, Bourdieu's concept refers to what Wimmer (2008a) and Barth (1994) propose as a macro-level analysis of boundarydrawing mechanisms, including the influences of institutions, political agendas, power distributions and networks. With the data at hand, however, I will focus on a rather micro-sociological approach, seeing "ethnic boundaries as 'emerging' from the minutiae of cognition, action, or interaction, variously conceived as conversational encounters" (Wimmer 2008a, p. 986). To enrich the following 
analysis, I will now provide information about the community's history and recent developments which form part of the narrations of the respondents.

The Quilombo Campinho da Independência has a story different from most of the Quilombos in Brazil. Generally, these were founded as more or less "safe havens" by fugitive Afro-Brazilian slaves, who gathered together to find shelter and protection in community-like structures, and additionally to build cells of resistance against their oppressors. The foundation of the Quilombo Campinho did not have such violent origins. According to the common community narrative, three sisters worked as household slaves on a plantation near the colonial hub city of Paraty. When the plantation owner went bankrupt at the end of the 19th century, he endowed the three women with his land. The endowment did not include any written documentation, which would later become a problem. The community grew from the families of the three women who settled on the land and dedicated themselves to the cultivation of local crops. Until the 1970s, the community stayed rather undisturbed. However, the situation changed with the building of Highway 101 between Rio de Janeiro and São Paulo, which cut through the Quilombo community and spurred the development of extensive tourism around Paraty. Investors became interested in the touristic and realestate possibilities of the area, while the Quilombo dwellers tried to preserve their claims to the land. Many narratives evolved around the older generations' struggle to pay a lawyer, to represent their interests to politicians and lobbyists, and to fight against the tourism and real-estate industry - it is a narrative of an Afro-Brazilian David against a "development agenda" Goliath. The abeyance continued until the end of the 1990s. In 1994, the "Associação de Moradores do Quilombo Campinho" (AMOQC) - the Association of Quilombo Campinho Residents - was founded to institutionalize the community's endeavors of receiving official acknowledgement of their customary right to the land. This acknowledgement and official documentation had to be accompanied by the acknowledgement of the community as a Quilombo community - as lawful descendants of former African slaves. At the end of the 1990s, the political agenda in the state of Rio de Janeiro coincided with an anthropological investigation about the community's roots, proving that all families stem from the three original founding mothers and that they live a traditional Quilombo "lifestyle". Hence, the community received the official title "Quilombo Campinho da Independência", along with property rights to the land on 21 March 1999 as the first Quilombo in the state of Rio.

Ultimately, the newly granted title is an acknowledgement of ethnic boundaries surrounding the community, according to the category of being descendants of 
former slaves. These boundaries identify category-bound activities (Sacks 1992) related to the in-group of Quilombolas. The main goal and the main defining feature of the Quilombo community is its self-sufficiency in terms of employment and income, an education system which considers the history of Afro-Brazilians, preservation of knowledge and traditions, a strong connection to the soil in terms of agriculture and harvesting of traditional crops, and connections to other traditional communities in Brazil. The main goal is to never have to leave the community for any undertaking, and to be independent from any outside product or service, while preserving the Quilombo ethnicity across and within the generations to come. The AMOQC tries to support these objectives in several ways. In the early 2000s, community tourism was established, offering a session with a grió, an older storyteller of the Quilombo, a meal in the community-owned restaurant, a visit to the agroforestry and the arts shop. This ensures employment for many Quilombo inhabitants. Furthermore, several workshops are held, aimed especially at the younger generations to convey and instill what is considered Afro-Brazilian culture. Amongst these are jongos (sessions of African dance), capoeira sessions, education on traditional medicine and herbs, or the manufacture of traditional arts and crafts. The final step to be accomplished is a school run not by the state but by the Quilombo community itself - a motion to this end is currently under review by the prefecture of the state of Rio de Janeiro.

\section{Data and Analysis}

In investigating the linguistic construction of ethnic boundaries, I will look at an extract from an interview conducted in the Quilombo in September 2011. This interview is part of a larger corpus comprising six semi-structured interviews with AMOQC members and approximately four hours of narratives within the scope of the touristic offerings of the Quilombo. I was restricted in the selection of my interviewees by the AMOQC president, who only allowed me to interview other AMOQC associates, but not random people from the Quilombo community. This decision was based upon negative experiences with other researchers in the past. As the first Quilombo to be acknowledged in the state of Rio, they have received a lot of scientific attention, not always in accordance with the wishes of the Quilombo Campinho residents. Although my circle of informants was restricted, the data still shows interesting boundary-making strategies with regards to questions of ethnicity. The narratives edited for tourists during the grio sessions also show how the Quilombo inhabitants want to present themselves and their history in the ethnic contexts of Brazil. 
The extract is from an interview with 35 year old 'C', a Quilombola who was born and raised in the Quilombo and plays an active part of the AMOQC, especially working in matters of tourism. In the selection, she speaks about different "others" entering the community and the different effects their presence has or would have on the Quilombo endeavor of preserving their traditional culture. We will see what kind of linguistic devices are used to introduce the categories of the Quilombolas as the "we-group," and different others as "they-groups". Furthermore, we will learn how and what kind of boundaries are drawn between them. Finally, we will examine how those boundaries are challenged or even changed in the course of conversation. Although there may be more to find in the transcripts in terms of conversational analysis and the in-group/out-group determination, the focus of this specific analysis will be on strategies either fortifying or mitigating the boundaries the speaker establishes between two or more groups. In order to present a structured investigation, the transcripts will be analyzed in consecutive sequences, first looking at the semantic level of the words used, secondly focusing on the discursive level of the utterances. Finally, prosodic features and/ or speech-accompanying gestures will be considered to complement the analysis where applicable.

The data has been transcribed with the EXMARaLDA package (Schmidt/ Wörner 2009, www.exmaralda.org) following a combination of the transcription proceedings of HIAT (Ehlich/Rehbein 1976) and GAT 2 (Selting et al. 2009). In the sequences, there is a tier for the utterances of $\mathrm{C}(\mathrm{C}[\mathrm{v}])$, prosodic features $(\mathrm{C}$ [pro]), speech accompanying gestures $(\mathrm{C}[\mathrm{k}])$, and a free English translation (C [eng]). In the last tier, the utterances of the interviewer are displayed.

\section{The Construction of Durable Boundaries}

Dichotomies do not always depict the multi-layered and intertwined social realities of societies such as Brazil. What can be observed in the Quilombo Campinho case is a negotiation of prevalent and new categories, a striving toward validation of those categories and attributions of malleable characteristics. Hence, I agree with Barth's (1994, p. 13) statement that

"[...] the analysis of ethnicity [is] blunted when cast in the fashionable rhetoric of 'we and the other'. [...] [E]thnic relations and boundary constructions in most plural societies are not about strangers, but about adjacent and familiar 'others'. They involve co-residents in encompassing social systems, and lead more often to questions of how 'we' are distinct from 'them', rather than a hegemonic and unilateral view of the 'other'". 
However, in the first part of the analysis, we will focus on the establishment of durable boundaries, establishing a rather clear-cut view of "we" and "other" relative to the speaker. These questions of how and why "we are distinct from the 'others"' are a recurring topic (van Dijk 1987) in the interviews and tourist narratives of the Quilombo dwellers. To identify the categories established in the interviews by the speaker, I will follow what Hausendorf and Kesselheim (2002, p. 270, referring to Hausendorf 2000) have called the step of "marking and identifying of a social group". Hence, in this first section, we will see what kinds of groups the speaker identifies, and what linguistic devices are used to support this identification. Prior to the following conversational fragment, C talks about the beginnings of the projects after the group's official recognition in 1999, and how the AMOQC tried to start its work in terms of a newly acknowledged Quilombo community.

[1]

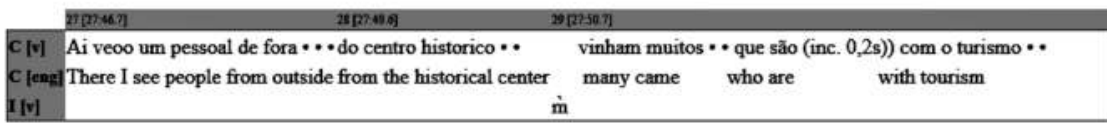

[2]

\begin{tabular}{|c|c|c|c|c|}
\hline & 30 p27.3421 & 112019] & $12[27592]$ & 19p:013 \\
\hline $\mathrm{C}[\mathrm{v}]$ & -vêm passear a nossa comunidade $((1,7 \mathrm{~s}))$ & \multirow{3}{*}{\multicolumn{3}{|c|}{$\begin{array}{c}\text { ehhh }((1,2 s)) \text { ai a gente/nosso } \cdots \text { "Que são de } \\
\text { change of pitteh } \\
\text { there we/our } \quad \text { "That they are }\end{array}$}} \\
\hline C [pro] & & & & \\
\hline C [eng] & they come to take walks in our community & & & \\
\hline $\mathbf{I}[\mathbf{v}]$ & $\dot{\mathrm{m}}$ & & & $\mathrm{n}$ \\
\hline
\end{tabular}

[3]

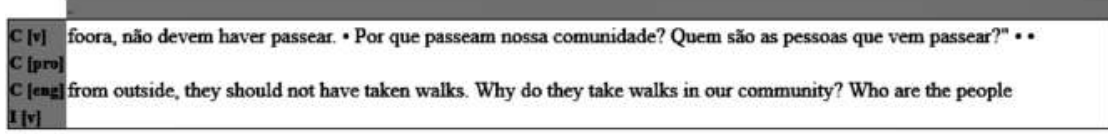

[4]

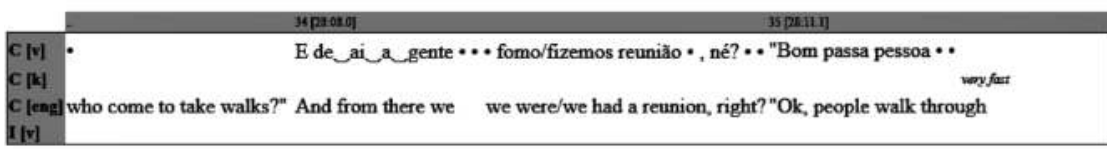

[5]

\begin{tabular}{|c|c|c|c|c|}
\hline & & & अ[21159 & $3[28283]$ \\
\hline $\mathrm{C}[\mathrm{v}]$ & \multirow{2}{*}{\multicolumn{4}{|c|}{$(($ inc $.0,35))$ que eles vinham $\cdots$ já para eles por que? $\cdots$ O que que eles querem da nossa comunidade?" $\cdots$ Ai }} \\
\hline $\mathbf{C}[\mathbf{k}]$ & & & & \\
\hline $\begin{array}{l}C \text { lengl } \\
I|v|\end{array}$ & that they came & so for them why? & What do they want from our community?" & There \\
\hline
\end{tabular}


As mentioned above, we will first look at the semantic level of this sequence. The speaker starts by introducing an undetermined group um pessoal [line 1], characterized by the attribute of being de for - 'from outside', more specifically from the center of the touristic hub of the area, the city of Paraty. They also receive the attribute of being muitos [line 1] - 'a lot', a rather undefined quantity which invites the impression of a fear of being overrun. The group of outsiders is immediately related, if not contrasted, to the group of 'our community' nossa comunidade [line 2], also represented by the follow up personal pronoun a gente - 'we'. The use of personal and possessive pronouns in this short extract in terms of group identification is striking. Every time $\mathrm{C}$ speaks about the community is accompanied by the possessive pronoun nossa - 'our' [line 2, 3 and 5]. The "others" are presented in terms of the personal pronoun eles - 'they', starting in line $4 /$ time slot 35 . Whereas at the beginning of the extract, C mostly uses the conjugated verbal form unaccompanied by a personal pronoun to refer to um pessoal, in the last sentence, eles always precedes the verbs. One has to take into account that um pessoal requires a verb conjugation in the singular form. However, it represents a multiplicity of people. This explains the missing concordance between the verbal form and the personal pronoun. The speaker constantly applies the 3 rd person plural conjugation with the subject. The use of the personal pronoun eles can be read as an emphasis of "them" and reinforces the contrast to "us" in terms of 'our community', especially considering that Brazilian Portuguese belongs to the so called pro-drop-languages. It infers that the use of the personal pronoun is not obligatory. ${ }^{1}$

The verbal forms of moving connected with the out-group reveal the Quilombo as the local point of reference from a spatial point of view. The outsiders 'come' (vinham - 'they came', vêm - 'they come', vem passear - 'they come to take walks') into the community, which is the deictic reference point of this group. The verb 'come' can be interpreted as a movement towards the speaker's deictic centre of the utterance. It can be concluded that the verb 'come' hence signals proximity (cf. Fillmore 1975/1997). However, this proximity interactively enacted by the "people from outside" is evaluated negatively by the speaker, and the outsiders are rather displayed as intruders. Hence, it seems as if $\mathrm{C}$ would like the spatial boundary

1 Nonetheless, there is a debate as to whether Brazilian Portuguese, especially in colloquial and spoken contexts, may no longer belong to the group of pro-drop-languages. It "lost" three of the six verbal forms from peninsular Portuguese, hence using the personal pronoun becomes more frequent, if not obligatory, to prevent ambiguity (cf. Weydt 1997, p. 14). 
around the Quilombo community to become more durable as it is threatened by "outsiders".

On a discursive level, $\mathrm{C}$ uses an interesting discursive means that could be labeled as direct collective speech [line 2-3] (conf. e.g. Günthner 1997; Roth 2005). She reconstructs the opinion of the "we-group" by directly enacting the reactions of the Quilombo community towards the outsiders. In prosodic terms, the change of perspective can be noticed by the change of pitch in her voice. Another incidence of direct speech follows in lines 4 and 5, when $C$ summarizes the enquiries of the reunion dealing with the "others" in the voice of the Quilombo community. On the one hand, this strategy of "choral dialogue" (Tannen 1989, p. $133 \mathrm{f}$.) has the effect of strengthening the boundary between the "people from outside" and the "we", as C is reconstructing a generic "we". As such, a linguistic strategy displays opinions and attitudes of the many; the collective speech carries more weight vis-à-vis the out-group than the speaker's single or personal opinion. On the other hand, by using the "chorus", $\mathrm{C}$ also sets back her own and very personal opinion and "keeps face" by "avoiding negative self-presentation" during "negative other-description" (van Dijk 1987, p. 118) in the presence of the interviewer, herself a "person from outside". With the choral dialogue, she produces a certain image of authenticity (cf. Hausendorf 2000 , p. 379 f.), in which only things heard in the community about the "others" are reproduced.

The choral dialogues in both cases [lines 2-3 and lines 4 and 5] consist of a statement about the people from outside ('They are from outside, they should not have taken walks' and 'people walk through'), followed by two rhetorical questions each ('Why do they take walks in our community? Who are the people who come to take walks?' and 'they came so for them why? What do they want from our community?'). The speaker leaves those basic who-whywhat-questions unanswered, and makes the others appear even more alienated, opaque and questionable in the collective voice she uses. This alienation again strengthens the gap between the two introduced groups, and fortifies the boundary between them.

Now that the two groups are marked and identified, C proceeds to specify rules of legitimization, which could also be interpreted as category-bound activities (Sacks 1992) accepted by the in-group of Quilombolas. 
[1]

\begin{tabular}{|c|c|}
\hline $\begin{array}{l}\text { Ca }[v] \\
\text { Ca }[e n g] \\
\text { I }[y]\end{array}$ & $\begin{array}{l}\text { "O que que eles querem da nossa comunidade?" - A Ai descrubmis que era uma agência dee Paratyy que } \\
\text { "What do they want from our community?" } \\
\text { There where we found out that it is an agency from }\end{array}$ \\
\hline
\end{tabular}

[2]

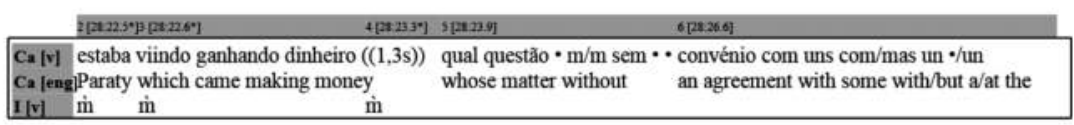

[3]

\begin{tabular}{|c|c|c|c|c|c|}
\hline & & $7[\mathrm{~PB} 3007$ & $108319]$ & $10[283389$ & $11[20353]$ \\
\hline \begin{tabular}{|l|}
$\mathrm{Ca}[\mathrm{v}]$ \\
$\mathrm{Ca} \mid \mathrm{eng}$ \\
$\mathrm{I}[\mathrm{v}]$
\end{tabular} & $\begin{array}{l}\text { comunidade nosso trabalho tipo viv/ehh } \\
\text { jcommunity our work of the type livi/ }\end{array}$ & $\begin{array}{l}\text {-ehh questão } \\
\text { a matter of }\end{array}$ & $\begin{array}{l}\text { ehh } \cdot \text { paisagiismo } \cdot \text { rio } \\
\text { landscape art, the river, } \\
\text { m } \quad \text { m }\end{array}$ & $\begin{array}{l}\text { cachoeira. } \\
\text { the waterfall. } \\
\dot{\mathrm{m}}\end{array}$ & $\begin{array}{l}\text { Ai quando } \\
\text { Then when the }\end{array}$ \\
\hline
\end{tabular}

[4]

\begin{tabular}{l}
$\begin{array}{l}\text { Ca }[v] \text { vo/voltaram as pessoas fomos } \cdots \text { para } \cdots \text { esso sea prime/a a } \cdot \text { a ultima vez está veendo fez trabalho porque é que } \\
\text { Ca lenglpeople came back we were } \quad \text { for this would be the first the last time seeing that the work is done }\end{array}$ \\
\hline
\end{tabular}

[5]

\begin{tabular}{|c|c|c|c|}
\hline & $14[2 \pi \times 3]$ & $15[25: 0.6]$ & $16[28 \times 1.6]$ \\
\hline $\begin{array}{l}\mathrm{Ca}|\mathrm{v}| \\
\mathrm{Ca}[\mathrm{eng} \mid \\
\mathrm{I}[\mathrm{v} \mid\end{array}$ & $\begin{array}{l}\text { si alguém tiv/tem ganhar dineiro } \\
\text { because it is that if someone should eam money }\end{array}$ & $\begin{array}{l}\text { - com turismo lá na comunidAde } \\
\text { with tourism there in the communit }\end{array}$ & $\begin{array}{l}\cdots \text { foi aquele que } \\
\text { tyit was the one }\end{array}$ \\
\hline
\end{tabular}

[6]

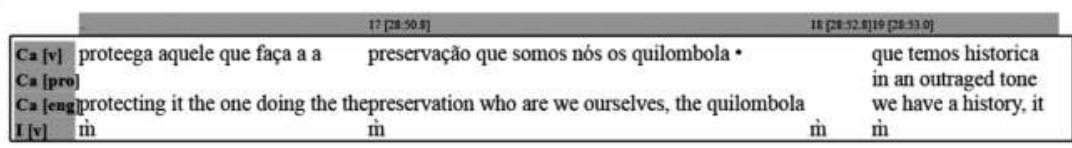

[7]

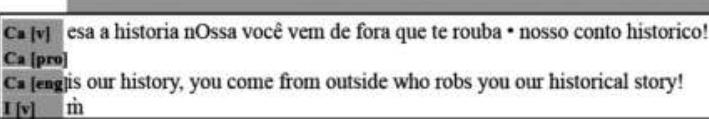

Transcript extract 2

In the first four lines, C identifies a group "behind" the 'people from outside' using the Quilombo for its purposes. In terms of boundary work, I will focus on the extract starting in line 5 . It seems as if $C$ changes the deictic perspective from inside the community and herself as part of the "we-group," to a bird's-eye perspective observing the community from a certain distance. When it comes to the question of who should earn money with tourism in the Quilombo, she suggests an answer with the indefinite pronoun alguém - 'somebody' [line 5]. This is accompanied by the local adverb lá - 'there' [line 5], signaling distance of the speaker from the locus of events. C proceeds with this distanced way of speak- 
ing by using the demonstrative pronoun aquele - 'that (one)' [line 5] twice when introducing the category-bound activities for the in-group regarding who may be legitimized to earn money within the community. Only then does she resolve her line of argumentation, determining who 'somebody' and 'that (one)' is, namely with somos nós os quilombola [sic!] - 'it is us the Quilombolas'.

Discursively, $\mathrm{C}$ creates an arc of suspense for the hearer by using different strategies to make the resolution even more convincing. By distancing herself using words like alguém, lá (na comunidade) and aquele, she expresses objectivity and exclusion of her personal opinion. The syntactic duplication of the relative clause initiated with aquele - which could also be recognized as "listing" (Roth 2005, p. 192) - reinforces and also delays the final argument. The utterance 'it is us the Quilombolas', hence, gains argumentative weight. The sequence concludes with a specification of attributes the speaker gives to 'us Quilombolas', an accentuation ("Herausstellung", Hausendorf 2000, p. 222 f.), and also culminates in an emotional climax. In an outraged tone, she emphasizes that the history they have is 'our history' - a historia nOssa, prosodically underlining the possessive pronoun 'our' [line 7]. The "other" is directly addressed in this part of the sequence in the form of a generalized voce - 'you' [line 7]. Whereas Roth (2005, p. 182), for example, depicts the generic you as a strategy to make a reference to the in-group, in the case of $\mathrm{C}$ the out-group, the 'people from outside' are referred to in this generalized form ${ }^{2}$. This gives the impression of an enacted dialogue between the Quilombolas and any member of the out-group, as 'you' is not specified and can be occupied by anybody. Together with C's word choice rouba'he/she steals', the outraged pitch and the generalized you, the sequence ends in a rather dramatic way, without leaving any negotiable space between the in-group of Quilombolas and the out-group of 'people from outside'. The speaker makes it clear that the boundary between the two groups is durable and not movable.

\section{The construction of permeable boundaries}

In the following extract, we will look at the linguistic means $\mathrm{C}$ uses to establish boundaries between an in-group and an out-group, which are not as clear-cut and durable as in the former example. Rather, the boundaries might be "blurred" (Wimmer 2008, p. 1030) or, in other words, they are made permeable.

2 The reference to the in-group with a generalized you is what $\mathrm{C}$ carries out in line 11: que te rouba nosso conteúdo historico! - 'who robs you our historical substance!'. Here she is referring to the group of Quilombolas affirmed by the follow up possessive pronoun nosso - 'our'. 
Before this sequence, C speaks about the formation of the Quilombo community starting with the three founding mothers in the 19th century. She emphasizes that only descendants of those three women and their expanding families are allowed to live in the community, and are recognized as part of the Quilombola we-group. The interviewer asks whether that might pose a problem in terms of marriage rules, and $\mathrm{C}$ argues that today it is not a problem anymore to marry somebody who is not a Quilombola her/himself. However, in the course of her argument, it appears as if the community does not have a unified opinion on the matter, and as if she was looking for arguments in favor of marriage outside the Quilombo community. The transcription begins when $\mathrm{C}$ relates the issue to her own personal story. She is married to one of three foreigners living in the Quilombo. One French man, one Argentinean man and one Ecuadorian woman are each married to a Quilombola, and are recognized as a special group with their own category, distinct from the pessoal de fora - 'people from outside' introduced above.

[1]

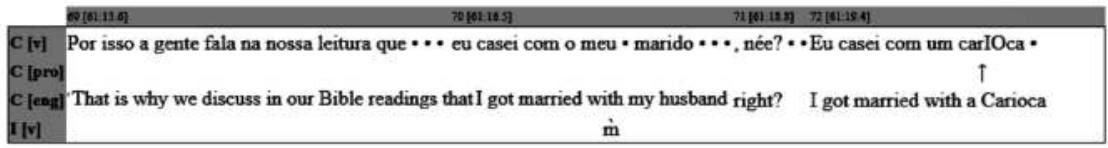

[2]

\begin{tabular}{|c|c|c|}
\hline & $14[6: 222]$ & $7[01252]$ \\
\hline $\mathrm{C}[\mathrm{v}]$ & meu marido faleceu $\cdots$ casei com ele $\cdots$ & é uma pessoa que vem de \\
\hline $\mathbf{C}[\mathbf{k}$ & \multicolumn{2}{|c|}{ 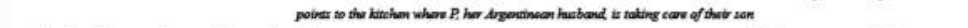 } \\
\hline $\begin{array}{l}\mathrm{C}[\mathrm{esg}] \\
\mathrm{I}[\mathrm{v}]\end{array}$ & $\begin{array}{l}\text { my husband passed away I married him } \\
\text { m }\end{array}$ & he is a person that comes \\
\hline
\end{tabular}

[3]

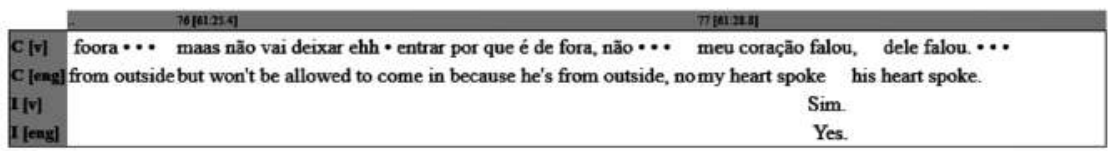

[4]

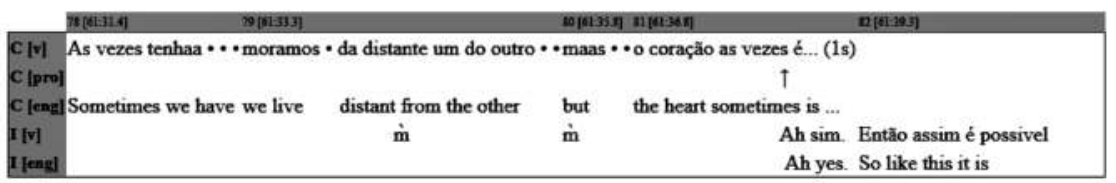

Transcript extract 3

The speaker separates her own personal life from her social membership to the in-group of Quilombolas. This can be noticed in the switch from the initial a gente fala na nossa leitura - 'we discuss in our Bible readings' [line 1], contrasted with 
the personal story that eu casei com o meu marido - 'I got married with my husband' [line 1]. This is followed by three short statements about the development of her personal life, all using the first person singular as origo [line 1-2]. Contrasting the third person personal and possessive pronouns with the first person personal and possessive pronouns, she illustrates that however "deviant" her personal life might be, she still belongs to the we-group. Naturally, the boundary between C's social and personal identity (cf. Fearon 1999) can be seen as permeable here.

In the following, $\mathrm{C}$ specifies the category her current Argentinean husband belongs to. As with the other out-group members, he is labeled as a 'person that comes from outside' [lines 2-3]; however, the speaker introduces a categorybound activity differentiating her husband from other out-group members: the involvement of the 'heart' [lines 3-4]. C transfers the solution of the marriage problem addressed above onto personifications of the 'heart' which 'speaks'. She puts her line of argumentation on a metaphorical level, so that hardly any counterargumentation is possible.

Discursively, the insertion of the personal story has another effect on the boundary between the Quilombolas and the out-group(s). The previously established "we-they" contrasts are softened or relativized by "I-he" sequences, forming a small we-group of its own but comprised of a Quilombola and an outsider. The boundary between "in" and "out" is relocated and a permeable space opens up. Furthermore, the speaker starts to distinguish the out-group of foreign spouses from any other outsider by means of syntactical constructions with mas - 'but'. Those constructions received a lot of attention in terms of prejudiced discourse (van Dijk 1987, p. 86 ff.), mitigating or strengthening stereotypes in discourse (Roth 2005, p. 202 ff.) or in discursive construction of national identities (Wodak et al. 2009, p. 36). To analyze their function in this specific sequence, we have to take into account " $(\mathrm{t})$ hat $[. .$.$] the strategic function of an (expressed) proposi-$ tion is determined by the nature of its link with another, previous or following, proposition" (van Dijk 1987, p. 87). In the two cases at hand, the mas-construction has an effect of boundary weakening by "perforation". In line 3, the adversative conjunction 'but' follows the proposition that her husband is a 'person from outside'. Hence, this fact is mitigated by arguing that this alone is not the cause for exclusion along the durable boundary between "us" and "them". If the 'heart' [line 3] plays a crucial role in Quilombola relationships, this boundary becomes permeable. In the second incident, the 'but' is related to the small "I and he" we-group, and again the argument of the 'heart' [line 4] resolves the introduced problem of being separated occasionally. The balancing and relativizing function of mas is further emphasized prosodically through the lengthening of the vowel 'a'. 
In the following sequences, $\mathrm{C}$ makes her final argument about why foreign spouses are no "real" outsiders, and how the boundary towards them is permeable rather than durable. Prior to this last excerpt, she states that some people from the community would still prefer the Quilombolas to only marry people from within the community. She voices her opinion that nobody can influence love, and that this is a decision of 'heart [...] soul [...] and god' (coração [...] alma [...] deus). After the interviewer's question whether the land then could be sold or transferred to the foreign spouses in the Quilombo, she negates the question right away.

[1]

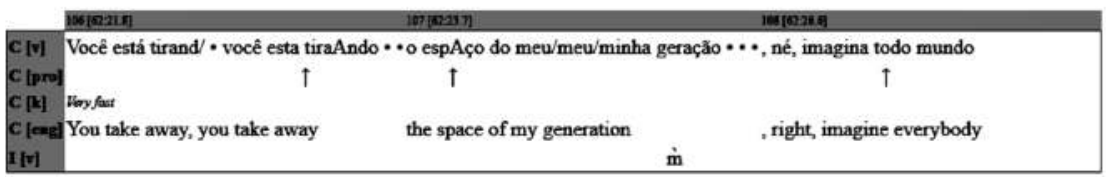

[2]

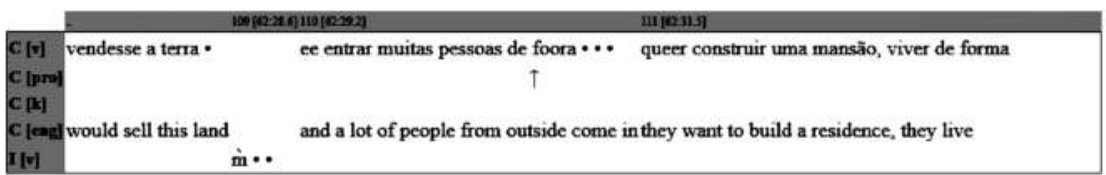

[3]

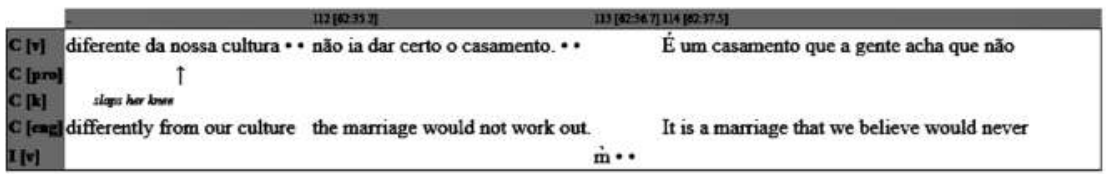

[4]

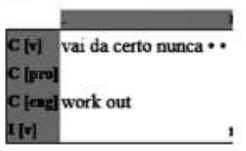

Transcript extract 4

$\mathrm{C}$ again uses the generalized you in the beginning of this sequence. As in the sequence above, this generalized you refers to the out-group, and is presented with a negative connotation accompanied by the activity 'you take away the space of my generation' [line 1]. Once more, this seems like an enacted dialogue with the generalized "other". This impression is supported by C's salient tone pitches in words she considers important: tirando ('take away'), espaço ('space'), todo mundo ('everybody'), de fora ('from outside') and nossa ('our'). Sometimes the tone pitch is even accompanied by lengthened vowels. The emphasis of nossa cultura - 'our culture' - in contrast to the pessoas de fora - 'people from outside' [line 2] is not 
only laid on by the tone pitch, but also by the gesture and sound of slapping her knee thoroughly during the enunciation of the word nossa. All in all, this sequence shows a very emotional reaction of the speaker towards the question of selling the land and of admitting outsiders into the Quilombo community. However, she still relates this rather general out-group to the previously introduced group of foreign spouses by saying that people who want to live differently from the Quilombo culture could never have a successful marriage inside the Quilombo [lines 3-4].

[1]

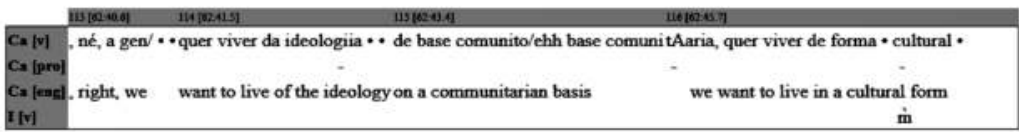

[2]

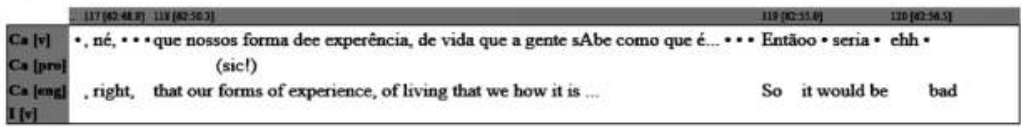

[3]

\begin{tabular}{|c|c|c|}
\hline \multicolumn{3}{|c|}{$231[2093[2][3003]$} \\
\hline C. $\{v\}$ & ruim - se vinha essas outras pessoas de fora. & Vêm algumas pessoas de fora mAs sabendo quee. . \\
\hline Ca |pro| & (sicl) & \\
\hline Ca lengl & if other people from outside would come. & There come some people from outside but knowing that we \\
\hline $\mathrm{I}[\mathrm{v}]$ & & \\
\hline
\end{tabular}

[4]

\begin{tabular}{|c|c|c|c|}
\hline & & 1240लx & 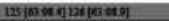 \\
\hline$C_{a}[v]$ & gente tem uma cultu/de maneira cultural que temo qu & que viver a bas/a partir dai. .. & E esa cultura \\
\hline$C a$ [pro] & (sicl) & $\uparrow$ & \\
\hline $\begin{array}{l}\text { C. [engl } \\
I[v]\end{array}$ & have a cultu/a cultural way here & that we live on the bas/from there. & And this \\
\hline
\end{tabular}

[5]

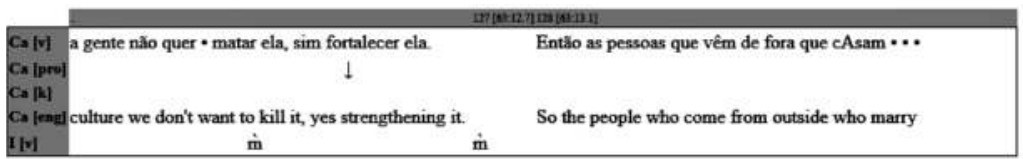

[6]

\begin{tabular}{|c|c|c|c|}
\hline & 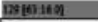 & $180[0.173$ & $113 x \pi$ \\
\hline $\operatorname{Ca}|v|$ & \multicolumn{2}{|c|}{ nāo pode • ehh - • as vezes traz os modelos das suas cultura para cá } & $\begin{array}{l}\text { para sua mão mais a gente sabe que a gente } \\
\text { puming ha hant an she hep with a }\end{array}$ \\
\hline $\begin{array}{l}C \times|e n g| \\
I|v|\end{array}$ & they cannot & sometimes they bring models of their cultures in & $\begin{array}{l}\text { in their hand but we know what we have is } \\
\text { m }\end{array}$ \\
\hline
\end{tabular}

[7]

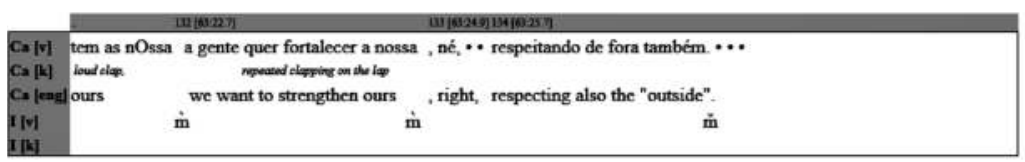


In the following, she redefines category-bound activities for the in-group of Quilombolas that also apply for the second type of out-group, the foreign spouses. Only following the rules of the Quilombo community makes them different from the other out-groups that $\mathrm{C}$ introduced in the first extract above. $\mathrm{C}$ uses thirdperson plural pronouns, verb endings and possessive pronouns for the description of the activities: a gen/ quer viver ('we/ want to live'), quer viver ('we want to live'), nosso[a]s [sic!] forma[s] [sic!] ('our way'), a gente sabe ('we know') [lines 4-5]. The subsequent conclusion of $\mathrm{C}$ is that there are two types of 'people from outside'. Here, we can find a strategy Hausendorf and Kesselheim (2002, p. 266) labeled "contrasting two different social groups":

"By comparing social groups participants draw multiple boundary lines between themselves and others, or among several out-groups. In accordance with their concrete communicative goals and embedded in a broader socio-political context, they place the groups at greater or lesser distance from each other, they express their comparability and their incompatibility, and define thereby the relative position of these social groups in a multidimensional 'social space'".

C splits the group of people from outside into essas outras pessoas de fora - 'those other people from outside' and algumas pessoas de fora - 'some people from outside'. The word choice in identifying the two groups illustrates the speaker's attitude towards them. Essas ('those') marks a certain distance from the speaker as part of the in-group. This is strengthened by outras ('other'), which already indicates that there is another group apart from them. The outras also excludes 'those people from outside' in terms of the category-bound activities for the ingroup. They are the ones not complying with the rules, not following a Quilombola lifestyle, and hence they could not marry successfully into the Quilombo community. Strictly speaking, algumas pessoas de fora - 'some people from outside' could also be seen as a sub-group of the people from outside in general. Thus, $\mathrm{C}$ not only contrasts two different groups, but also undertakes "dividing a social group into subgroups" (Hausendorf/Kesselheim 2002, p. 277). Algumas ('some') is an exception to the general other which is characterized by $\mathrm{C}$ through another "but"-construction: 'there come some people from outside, but knowing...'. The vowel in mas ('but') again is emphasized, this time not with a prolonged vowel, but with an exposing accent. Compared to the other group from outside, not "playing the same game" (Barth 1969, p. 15) of the Quilombolas, C depicts the 'knowing' group from outside as closer to her own we-group. By doing this, she also legitimizes the decisions of her personal life concerning the Argentinean husband, as she certainly categorizes him belonging to the group of algumas pessoas de fora. However, the convergence of the we-group and the 'knowing group of outsiders' 
does not imply a "fusion" (Wimmer 2008, p. 1031) of existing categories. Rather, by introducing a second group between the we and the other, she strengthens the boundary between the two "real antagonists". At the same time, through acknowledging that not everyone is excluded right away, but that there are exceptions to the rule, she keeps her face in the presence of the interviewer.

The final argument of the speaker before moving to another topic in the interview is that cultural features of the outsiders' backgrounds do not stand a chance of being incorporated into the Quilombo community [lines 9-10]. Instead, she stresses the main goal of the we-group in terms of cultural preservation: a gente sabe que a gente tem a nossa a gente quer fortalecer a nossa - 'we know that what we have is ours, we want to strengthen our (culture)' [lines 9-10]. She closes her argument with three utterances of 'we' (a gente) and two incidences of 'our' (nossa) related to the word 'culture' (cultura) in line 9. The above citation is accompanied by clapping on the lap, again highlighting and dramatizing the words 'we' and 'our'. Consequently, the we-group and the boundary around them is reinforced in this final argument of the speaker.

To conclude, $C$ establishes three different groups in the course of the sequences we have taken a closer look at so far. One is the we-group of Quilombolas, legitimized by genetic lineage to the three founding mothers and by category-bound activities of "Quilombo-culture". The second group is the out-group, consisting of 'people from outside', which the speaker conveys as intruders, and in terms of marriage as unsuitable partners for the Quilombola people. The third and final group is again an out-group, but closer to the we-group. They are labeled as 'knowing' people from outside who comply with the rules of the Quilombo, and hence might be suitable spouses even though they come from outside. C establishes "multiple boundary lines" (Hausendorf/Kesselheim 2002, p. 268) between the in-group and others in these extracts. Regarding the use of linguistic means and content, the boundary line to essas outras pessoas de fora has a durable quality, whereas the boundary to algumas pessoas de fora is permeable. Still, the boundary around the Quilombo we-group never dissolves or blends in with another outgroup. Every time a higher grade of permeability is indicated, the speaker makes sure to remind the interviewer of the boundary around the we-group.

\section{Conclusions}

We have seen that $C$ uses manifold linguistic strategies of mitigation or strengthening of ethnic boundaries between her own we-group and different types of outsiders. She establishes boundaries of different qualities. Considering the outgroup of 'people from outside' generally, "we" and "other" are divided by a durable 
boundary which cannot be crossed. The other out-group of foreign spouses - or other spouses from outside complying to the rules - is connected to the Quilombo through a rather permeable boundary "selectively permitting passage" (Schiffauer et al. 2012, p. 100) under certain circumstances. The permeability of one boundary increases the durability of the other in the case of the Quilombo. The distance to the "real" out-group is actually widened when another group is introduced between them.

Two other conclusions can be drawn from C's boundary-making strategies. When established ethnic boundaries are challenged, as in the case of marriage rules in the Quilombo, subjects try to negotiate and legitimize their new placement in the social field. As for foreign spouses, the boundary switched due to social transformations within the community. Reality superseded the norm of only marrying inside the Quilombo, and the new permeable boundary reflects these transformation processes. It seems as if the speaker would mediate between two poles of past and present - norm and normality. She tries to preserve older norms of exclusion based on ethnic categories. On the other hand, she introduces the permeable boundary in terms of internal transformation processes. However, she always gives an impression of continuity by strengthening the "we" of the Quilombolas to prevent the permeable boundaries from reaching a point she may regard as too porous. Finally, it can also be seen that mechanisms of relativizing and "saving face" during the negotiation of boundaries play a crucial role for boundary-making in conversation.

This paper has focused on a micro-level analysis of linguistic boundary making. Surely, a meso- and macro-level analysis, as Wimmer (2008a) and Barth (1994) propose, would be of further benefit toward enriching the data and providing a more thorough understanding of ethnic boundary-making strategies within the Quilombo and elsewhere.

\section{Transcription (partly following HIAT and GAT)}

$\begin{array}{ll}. . & \text { - micro-pause } \\ \ldots & \text { - pause shorter than } 0,5 \text { seconds } \\ (1 \mathrm{~s}) & \text { - pause between } 0,5 \text { and } 1 \text { second } \\ \text { (inc. } 0,5 \mathrm{~s}) & \text { - pause longer than } 1 \mathrm{~s} \\ \text { tenhaa or tenhaaa } & \text { - duration of incomprehensible parts } \\ \text { carlOca } & \text { - elongated vowels } \\ \text { tiv/tem } & \text { - auto-correction of the speaker }\end{array}$


- salient upwards change of tone pitch

- salient downwards change of tone pitch

- $\mathrm{m}$ (backchannel behaviour) with falling tone

$\mathrm{m}$

- $\mathrm{m}$ (backchannel behaviour) with falling and rising tone

\section{References}

Asmuß, Birte: „Zur interaktiven Aushandlung von Teilnehmerkategorien in interkultureller Kommunikation“. Linguistik Online, 14(2), 2003, pp. 107-121.

Barth, Frederik: Ethnic groups and boundaries. The social organization of culture difference. Universitetsforlaget: Oslo 1969.

Barth, Frederik: "Enduring and Emerging Issues in the Analysis of Ethnicity". In: Vermeulen, Hans / Govers, Cora (eds.): The Anthropology of Ethnicity. Het Spinhuis: Amsterdam 1994, pp. 11-32.

Bourdieu, Pierre: The Field of Cultural Production. Polity Press: Cambridge UK 1993.

Brubaker, Rogers: "Ethnicity without groups." Archives of European Sociology, 43(2), 2002, pp. 163-189.

Bucholtz, Mary / Hall, Kira: "Language and Identity". In: Duranti, Alessandro (ed.): A Companion to Linguistic Anthropology. Basil Blackwell: Oxford 2004, pp. 268-294.

Ehlich, Konrad / Rehbein, Jochen: „Halbinterpretative Arbeitstranskriptionen (HIAT)“. Linguistische Berichte, 45, 1976, pp. 21-41.

Fearon, James D.: “What is Identity as we now use the word?". Stanford University, 1999.

Fillmore, Charles J.: Lectures on Deixis. Stanford: CSLI. 1975/1997.

Günthner, Susanne: „Direkte und indirekte Rede in Alltagsgesprächen. Zur Interaktion von Syntax und Prosodie in der Redewiedergabe“. In: Schlobinski, Peter (ed.): Syntax des gesprochenen Deutsch. Westdeutscher Verlag: Wiesbaden 1997, pp. 227-262.

Hausendorf, Heiko: Zugehörigkeit durch Sprache. Eine linguistische Studie am Beispiel der deutschen Wiedervereinigung [= Reihe Germanistische Linguistik]. Niemeyer: Tübingen 2000.

Hausendorf, Heiko / Kesselheim, Wolfgang: "The communicative construction of group relationships. A basic mechanism for social categorization". In: Duszak, Anna (ed.): Us and Others. Social identities across languages, discourses and cultures. Benjamins: Amsterdam 2002, pp. 265-289. 
Lamont, Michèle / Molnár, Virág: "The Study of Boundaries in the Social Sciences". Annual Review of Sociology, 28, 2002, pp. 167-195.

Le Page, Robert B. / Tabouret-Keller, Andrée: Acts of Identity. Creole-based Approaches to Language and Ethnicity. Cambridge University Press: Cambridge 1985.

Sacks, Harvey: Lectures on conversation (2 Vol. ed.), edited by G. Jefferson, introduction by E. Schegloff. Oxford: Blackwell 1992.

Sanders, Jimy M.: "Ethnic Boundaries and Identity in Plural Societies". Annual Review of Sociology, 28, 2002, pp. 327-357.

Schiffauer, Werner et al.: Initial Proposal for the Cluster of Excellence B/Orders in Motion at the European University Viadrina, Frankfurt (Oder). Unpublished 2012.

Schmidt, Thomas / Wörner, Kai: "EXMARaLDA - Creating, analysing and sharing spoken language corpora for pragmatic research". Pragmatics, 19(4), 2009, pp. 565-582.

Selting, Margret et al.: „Gesprächsanalytisches Transkriptionssystem 2 (GAT 2)“. Gesprächsforschung - Online-Zeitschrift zur verbalen Interaktion, 10, 2009, pp. 353-402.

Tabouret-Keller, Andrée: “Language and Identity”. In: Coulmas, Florian (ed.): The Handbook of Sociolinguistics. Blackwell: Oxford 1997, pp. 315-326.

Tannen, Deborah: Talking Voices: Repetition, Dialogue, and Imagery in Conversational Discourse. Cambridge University Press: Cambridge 1989.

van Dijk, Teun A.: Communicating Racism. Ethnic Prejudice in Thought and Talk. Sage: Newbury Park 1987.

van Houtum, Henk / van Naerssen, Ton: "Bordering, Ordering and Othering". Tijdschrift voor economische en sociale geografie, 93(2), 2002, pp. 125-136.

Weydt, Harald: „Neuere Entwicklungen in den Konjugationssystemen des brasilanischen Portugiesisch und des Deutschen. Ein typologischer Vergleich." In: Lüdtke, Helmut / Schmidt-Radefeld, Jürgen (eds.): Linguistica contrastiva: Deutsch versus Portugiesisch - Spanisch - Französisch. Narr: Tübingen 1997, pp. 11-23.

Wimmer, Andreas: "The Making and Unmaking of Ethnic Boundaries: A Multilevel Process Theory". American Journal of Sociology, 113(4), 2008, pp. 970-1022.

Wimmer, Andreas: "Elementary strategies of boundary making". In: Ethnic and Racial Studies, 31(6), 2008a, pp. 1025-1055.

Wodak, Ruth et al.: The Discursive Construction of National Identity. Edinburgh University Press: Edinburgh 2009. 

Bernhard Brehmer

(Greifswald)

\title{
The Cyrillic Script as a Boundary Marker between "Insiders" and "Outsiders": Metalinguistic Discourse about Script Choices in Slavic-German Bilingual Computer-Mediated Communication
}

\begin{abstract}
Gegenstand des Beitrags sind soziolinguistische Implikationen der Schriftwahl für das Verfassen von Beiträgen zu Diskussionsforen im sozialen Netzwerk StudiVZ, die sich an Nutzer mit russisch-, ukrainisch- oder bulgarischsprachigem Hintergrund richten. In diesen Foren finden sich sowohl Beiträge auf Deutsch, als auch in der slavischen Herkunftssprache der Nutzer. Für die in der slavischen Herkunftssprache verfassten Beiträge lassen sich unterschiedliche Schriftpräferenzen beobachten: Während einige Nutzer sich konsequent der kyrillischen Schrift bedienen, neigen andere dazu, ihre slavischen Beiträge in lateinischer Schrift zu formulieren. Im Artikel werden die sich daran anknüpfenden Debatten in den untersuchten Gruppen bezüglich des symbolischen Status der kyrillischen Schrift und der Legitimität der Nutzung des lateinischen Alphabets zur schriftlichen Kommunikation mit anderen bilingualen Studierenden in der slavischen Herkunftssprache analysiert. Besonders auffällig ist, dass derartige metaschriftliche Diskussionen nur in den Gruppen zu finden sind, die sich an Studierende aus dem russischsprachigen Raum richten. Hier wird der kyrillischen Schrift eine wichtige Bedeutung für die symbolische Konstitution einer „russischen“ Identität der jeweiligen Gruppenmitglieder zugewiesen, die „echte Russen“ von anderen russischsprachigen Zuwanderern mit geringeren sprachlichen und kulturellen Kompetenzen (z. B. russlanddeutsche Spätaussiedler) abgrenzt. Befürworter der Nutzung des lateinischen Alphabets verweisen demgegenüber auf instrumentelle Vorteile, v. a. die leichte Zugänglichkeit der lateinischen Schrift für alle Nutzer, unabhängig von ihrer individuellen (schriftlichen) Kompetenz im Russischen, und die einfachere technische Handhabung. Von keinem der beiden Lager wird dagegen die Nutzung des lateinischen Alphabets als charakteristisches Merkmal des Kommunikationsmediums Internet, als Mittel der Abgrenzung gegenüber monolingualen Vertretern aus den Herkunftsländern oder gar als symbolisches Emblem einer eigenen polykulturellen slavisch-deutschen Identität gesehen.
\end{abstract}

Schlagworte: Schriftwahl, Zweisprachigkeit, Identitätskonstruktion, computervermittelte Kommunikation

Keywords: script choice, bilingualism, identity formation, computer-mediated communication 


\section{Introduction}

The present paper explores the sociolinguistic implications of script choice in an immigration context. Based on public debates about script choices in bilingual discussion forums of a local German social network, my aim will be to "show how scriptural practices both index and constitute social hierarchies, identities and relationships". (Sebba 2012, p. 10) ${ }^{1}$ Language and script choices quite obviously mirror language ideologies of the bilingual users engaged in these discussion forums, and therefore function as a boundary marker between different members of the Slavic-German immigrant community.

Sociological, media and cultural studies have repeatedly shown that the advance of new communication technologies, including the development of the Internet, significantly contributes to maintaining relationships with the homeland in diaspora communities. ${ }^{2}$ Recent linguistic research has recognized the potential of online resources such as social networks for investigating multilingual practices which are not restricted to immigration contexts. ${ }^{3}$ My focus will be on online resources that aim to establish national networks between members who share a common Slavic background, but currently live in a German-speaking environment. These virtual spaces thus offer their users a place where they "can digitally

1 Sebba, Mark: „Orthography as social action: Scripts, spelling, identity and power”. In: Jaffe, Alexandra et al. (eds.): Orthography as Social Action. de Gruyter: Berlin 2012, pp. 1-19.

2 See Androutsopoulos, Jannis: „Multilingualism, diaspora, and the Internet: codes and identities on German-based diaspora websites". Journal of Sociolinguistics 10(4), 2006, pp. 520-547, here pp. $520 \mathrm{f}$., for references and an exhaustive review on the relevant literature.

3 Cf., among others, research overviews in Danet Brenda/Herring Susan (eds.): The Multilingual Internet. Language, Culture and Communication Online. University Press: Oxford 2007, Dorleijn Margreet/Nortier Jacomine: „Code-switching and the Internet”. In: Bullock Barbara E./Toribio Almeida J. (eds.): The Cambridge Handbook of Linguistic Code-Switching. University Press: Cambridge 2009, pp. 127-141, Leppänen Sirpa/ Peuronen Saija: „Multilingualism on the Internet”. In: Martin-Jones Marilyn/ Blackledge Adrian/ Creese Angela (eds.): The Routledge Handbook of Multilingualism. Routledge: London 2012, pp. 384-402, Androutsopoulos, Jannis: „Code-switching in computer-mediated communication”. In: Herring Susan/Stein Dieter/Virtanen Tuija (eds.): Pragmatics of Computer-mediated Communication. de Gruyter: Berlin 2013, pp. 667-694, Androutsopoulos, Jannis et al.: „Vernetzte Mehrsprachigkeit auf Facebook: Drei Hamburger Fallstudien". In: Redder Angelika et al. (eds.): Mehrsprachige Kommunikation in der Stadt: Das Beispiel Hamburg. Waxmann: Münster et al. 2013, pp. 161-198, Androutsopoulos, Jannis: „Networked multilingualism: Some language practices on Facebook and their implications". International Journal of Bilingualism 19(2), 2015, pp. 185-205. 
'hang out' and share their stories". (Mitra 2003, p. 1019) ${ }^{4}$ Previous research has shown that these virtual spaces represent sites for "the productive construction of new hybrid identities and cultures through the active, simultaneous process of maintenance and negotiation between the poles of an original home and a newly acquired host culture." (Sinclair / Cunningham 2000, p. 15) ${ }^{5}$ Linguistic reflections of such dual identities and the creative exploitation of multilingual proficiencies for various communicative purposes form a core topic in research on multilingualism. ${ }^{6}$ Thus, recent research on the relationship between language and identity in multilingual settings has called into question the static equation of languages and identities in the sense of the classical distinction between a 'we-' vs. 'theycode' by Gumperz'. New concepts have emerged which view clear-cut borders between languages as a mere ideological construct that does not apply to current multilingual (online) practices of young people in a globalized world. Concepts like "crossing"8, "polylanguaging", "translanguaging"10 or "metrolingualism"11 build on the assumption that there are rather flexible relations between language, ethnicity, nation and territory, which allows speakers "to manipulate the resources they have available to them"12. Thus, multilingual speakers often transcend language boundaries in their discursive practices, which embraces "the full range of linguistic performances" (Wei 2011, p. 1223) ${ }^{13}$ that multilingual language users

4 Mitra, Ananda: „Diasporic online communities”. In: Christiansen Karen/Levinson David (eds.): Encyclopedia of Community. Volume 3. Sage: Thousand Oaks, California, 2003, pp. 1019-1020.

5 Sinclair John/Cunningham Stuart: „Go with the flow: Diasporas and the media”. Television \& New Media 1, 2000, pp. 11-31.

6 Cf., e.g., Erfurt, Jürgen (ed.): „Multisprech“: Hybridität, Variation, Identität. OBST: Duisburg 2003, Hinnenkamp, Volker / Meng, Katharina (eds.): Sprachgrenzen überspringen: sprachliche Hybridität und polykulturelles Selbstverständnis. Narr: Tübingen 2005.

7 Gumperz, John J.: Discourse Strategies. University Press: Cambridge 1982.

8 Rampton, Ben: Crossing: Language and Ethnicity among Adolescents. Longman: London 1995.

9 Jørgensen, Normann J.: „Polylingual languaging around and among children and adolescents”. International Journal of Multilingualism 5(3), 2008, pp. 161-176.

10 Creese, Angela / Blackledge, Adrian: „Towards a sociolinguistics of superdiversity”. Zeitschrift für Erziehungswissenschaft 13, 2010, pp. 549-572.

11 Otsuji, Emi / Pennycook, Alastair: „Metrolingualism: fixity, fluidity and language in flux". International Journal of Multilingualism 7(3), 2010, pp. 240-254.

12 Otsuji / Pennycook 2010, p. 241.

13 Wei, Li: „Moment analysis and translanguaging space: Discursive construction of identities by multilingual Chinese youth in Britain". Journal of Pragmatics 43, 2011, pp. 1222-1235. 
have at their disposal. This employment of linguistic features that come from different sources is not even linked to the degree of proficiency in the involved languages. ${ }^{14}$ Scripts are one of those features which can be creatively used as a means of individual self-presentation in the context of their ideological association with certain languages, groups or situations.

\section{Scripts as symbols of identity}

Sebba $(2007, \text { p. } 82)^{15}$ stresses that scripts and orthographies "have functioned in different times and places as potent symbols of both nation and religion". This is especially true for the Slavic cultural space, which is characterized by the use of many different alphabets to represent the Slavic languages at different points in history. ${ }^{16}$ Besides the longer-lasting and geographically more widespread use of Glagolitic, Cyrillic and Latin, the Arabic, Greek and Hebrew scripts were also used at one time or another to render certain Slavic languages. The distribution of these alphabets was clearly influenced by religion: "Generally, there has always been a close correlation between alphabet and religion, though not necessarily one of cause and effect." ${ }^{17}$ Thus, there was always a close connection between Roman Catholic faith and the use of the Latin alphabet ("Slavia latina": Poles, Sorbs, Czechs, Slovaks, Slovenes, Croats), and between the Orthodox faith and the use of the Cyrillic script ("Slavia orthodoxa": Russians, Belarusians, Ukrainians, Bulgarians, Macedonians, Serbs). ${ }^{18}$

There are many instances in the history of the Slavic languages which hint at the high symbolic value that was (and still is) attributed to alphabets and orthographies. For reasons of space, I will limit myself to just three rather arbitrarily chosen examples: (1) The Glagolitic script, which was - according to most

14 Cf. Jørgensen 2008.

15 Sebba, Mark: Spelling and Society: The Culture and Politics of Orthography around the World. Cambridge University Press: Cambridge/New York 2007.

16 For a detailed account on the historical development and use of scripts in the Slavicspeaking area see Cubberley, Paul: „Alphabets and transliteration”. In: Comrie Bernard/ Stone Gerald (eds.): The Slavonic Languages. Routledge: London 1993, pp. 20-59.

17 Cubberley 1993, p. 20.

18 Of course, things are more complicated in reality than this binary division suggests at first glance. To mention just one example of a deviation from the dichotomy described above: Belarusian and Ukrainian were for some part of their history also written by using the Latin alphabet, especially in the areas that were under Polish rule up to World War II (cf., e.g., Mečkovskaja, Nina Borisovna: Belorusskij jazyk: Sociolingvističeskie očerki. Otto Sagner: München 2003, pp. 47-62). 
scholars - the first script in which Slavic texts were written ${ }^{19}$, continued to be used in Roman Catholic Croatia for religious purposes at least until the early nineteenth century (however, restricted to some regions, especially the Adriatic islands). Cubberley ${ }^{20}$ describes the reason for the continued use of the Glagolitic script for many centuries in church service as follows: "The apparent reasons are somewhat paradoxical, in that these were the areas dominated from early on by the Roman Church [...], so that one would expect Latinica to have been de rigueur. In fact, Glagolitic became the symbol of (partial or nominal) independence from Rome; it was tolerated by Rome as a small concession in permitting its continued influence where it mattered (in this case in the otherwise Byzantinedominated Balkans) [...]." (2) More recently, the symbolic status of alphabets and the close link between alphabets and/or orthographies and religion became obvious with the collapse of former Yugoslavia. Whereas both the Cyrillic and Latin script could officially be used in Yugoslavia for writing "Serbo-Croatian"21, Croatia dropped this digraphia ${ }^{22}$ immediately after gaining independence in 1990, thus adopting a Latin-only policy. Partially as a response to that, radical nationalist groups in Serbia insisted not only that the government should ban the use of the Latin script (Latinica) for writing Serbian, but even that it should cleanse the Cyrillic alphabet of letters that were introduced from the Latinica in the $19^{\text {th }}$ century (especially the letter $<j>$ ). However, a majority of linguistic moderates argued for keeping the Latinica (and, consequently, the digraphia) as a fact of their cultural past, but also due to economic and political reasons, i.e. they considered the ability to work with both alphabets as a means to facilitate contact with the Western world..$^{23}$ (3) Political and economic reasons also formed the basis for a discussion about introducing Latin script for writing Bulgarian when Bulgaria

19 It was specifically created by Constantine (better known by his monk name Cyril) during a mission from Byzantium to the Moravian Slavs with his brother Methodius in the early 860 s.

20 Cubberley 1993, p. 31.

21 The so-called Novi Sad Agreement ("Novosadski dogovor") from 1950 explicitly stated in one of its "conclusions" that the Latin and Cyrillic scripts should have equal status in Yugoslavia, and that Serbs and Croats are expected to learn both alphabets in school.

22 The term digraphia refers to situations where two or more scripts are simultaneously used to write one and the same language (cf. Dale, Ian: „Digraphia”. International Journal of the Sociology of Language 26, 1980, pp. 5-13, Grivelet, Stéphane: „Introduction to: Digraphia: Writing Systems and Societies". International Journal of the Sociology of Language 150, 2001, pp. 1-10).

23 Alexander, Ronelle: Bosnian - Croatian - Serbian: A Grammar with Sociolinguistic Commentary. University of Wisconsin Press: Wisconsin 2006, p. 419. 
was considered a candidate for entering the European Union..$^{24}$ This proposal was met with resistance in wide circles of Bulgarian society, one argument being the strong association of Cyrillic script with the Orthodox culture of Bulgaria, and its general national symbolic value.

Many more examples (including debates about reforms of alphabets or orthographical systems) could be adduced here, but the cited instances should suffice in proving that choices in writing systems always played an important role in nation and identity-building practices and ideologies in the Slavic world. Until today, scripts and spellings function as important identity markers and as "an index of political loyalty and religious allegiance" 25 . This becomes especially evident in times of social, political, economic and cultural transition, e.g. after the collapse of Yugoslavia or the former Soviet Union ${ }^{26}$ : "Orthographic battles are common in situations where identity and nationhood are under negotiation; this is because orthographic [and script, B.B.] systems cannot be conceptualized simply as reducing speech to writing, but rather [...] are symbols that carry historical, cultural, and politicized meanings." (Woolard / Schieffelin 1994, p. 65) ${ }^{27}$ These conclusions are normally drawn with regard to whole peoples or nations. My aim will be to adapt the alignment of scripts with temporal and geographical identifications to the study of script use in an immigration context, where transitions figure prominently not on a societal, but individual level. However, before investigating the role of the Cyrillic script for indexing and creating social structures in an immigration context, some comments should be made about possible technological limitations for using alphabets other than the Latin alphabet in computer-mediated (or electronic) communication.

24 Kronsteiner, Otto: Latinica und Kirilica? Gedanken zu einer entscheidenden kulturellen Herausforderung Bulgariens. Institut für Slawistik: Salzburg 2000.

25 Sebba 2012, p. 12, cf. also Bennett, Brian P.: „Orthography and Orthodoxy in post-Soviet Russia”. In: Jaffe, Alexandra et al. (eds.): Orthography as Social Action. de Gruyter: Berlin 2012, pp. 43-64.

26 Although this does not refer to Slavic languages, we could also mention here the postcolonial discussions about abandoning the Cyrillic script for rendering the national languages in a number of Central Asian successor states of the former Soviet Union, e.g. Mongolia, Azerbaijan, Turkmenistan or Tatarstan (see Sebba 2012, p. 3 for references). The case of Tatarstan is examined in detail by Wertheim, Suzanne: „Reclamation, revalorization, and re-Tatarization via changing Tatar orthographies”. In: Jaffe, Alexandra et al. (eds.): Orthography as Social Action. de Gruyter: Berlin 2012, pp. 65-101.

27 Woolard, Kathryn / Schieffelin, Bambi: „Language ideology”. Annual Review of Anthropology 23, 1994, pp. 55-82, cited in Wertheim 2012, p. 65. 


\section{Technological and social aspects of script choice in electronic communication}

Script choices are "usually made by tradition, by governments, or by the language users collectively $[\ldots]$. Even when digraphia exists in theory, $[\ldots]$ the individual language user rarely has a free choice of which to use. Where true digraphia does exist, however, the choice of one or other by an individual is almost certain to have social meaning [...]."28 Especially in the early days of the Internet, users who speak a language that is normally not written in the Latin alphabet (e.g., Greek, Russian or Japanese) were clearly restricted in their script choice. This was due to the fact that "the early internet operated on the seven-bit ASCII character encoding set (first published in 1967), which provided for the encoding of 128 characters based on the English alphabet, and therefore excluded the representation of languages with non-Latin script." (Androutsopoulos 2009, p. 224) ${ }^{29}$ Thus, it was only after the gradual development of the Unicode character-encoding standard since the early 1990s that the representation of symbols from a wide variety of writing systems on computer screens became increasingly available from a technical perspective (ibid.). However, as Androutsopoulos ${ }^{30}$ pointed out on the example of Latin-alphabet Greek (LAG, "Greeklish"), "its actual availability to individual users was still limited by their access to hardware and software facilities. This gap between technical possibility and individual availability led to the persistence of LAG as the lowest common denominator throughout the 1990s." Thus, informal Latinization of languages not written with Latin characters was the only option for participating in computer-mediated communication by using one's own native language, both for communication within the homeland and for transnational exchanges. ${ }^{31}$ In the $21^{\text {st }}$ century, however, technological developments rendered

28 Sebba 2012, p. 4.

29 Androutsopoulos, Jannis: „'Greeklish’: Transliteration practice and discourse in a setting of computer-mediated digraphia”. In: Georgakopoulou Alexandra/Silk Michael (eds.): Standard Languages and Language Standards: Greek, Past and Present. Ashgate: Farnham 2009, pp. 221-249.

30 Androutsopoulos 2009, p. 224.

31 The application of Latin characters to render these languages often lacks stability among the individual users. The informal ways of Latinization in Internet discourse have been described for several non-Latin-alphabet languages, including Greek (Koutsogiannis, Dimitris / Mitsikopoulou, Bessie: „Greeklish and Greekness: trends and discourses of 'glocalness'”. Journal of Computer Mediated Communication 9(1), 2003, Androutsopoulos 2009), Arabic (Palfreyman, David / al Khalil, Muhamed: „A Funky Language for Teenzz to Use': Representing Gulf Arabic in Instant Messaging”. Journal of Computer 
it more or less unnecessary to resort to Latin characters when using, e.g., Russian for electronic communication. Even in cases where no Cyrillic fonts are available on a local computer (e.g., in Internet cafés outside the Cyrillic-writing area), there is always the possibility to use transliteration tools which are freely accessible on the Internet, thus allowing one to convert a Latinized Russian text into Cyrillic very easily. ${ }^{32}$ However, Latinization of languages written in another alphabet than the Latin still does occur on the Internet. For Greeklish, Androutsopoulos ${ }^{33}$ states that "[i]n contexts of transnational communication, such as mailing lists with worldwide-dispersed members, 'Greeklish' has ensured, and still does ensure, that even the few users without access to the Greek script will be able to participate. In sum, even though an increasing number of Greek internet users had access to the Greek script by the late 1990s, LAG was so firmly established among early adopters of computer-mediated communication that it was referred to as the old writing method' [...]. One might suspect that it was in this transitional period, when both scripts were available to an increasing number of users, that symbolic values of LAG such as the 'code of the internet' or the 'code of the e-mail' [...] were established." Thus, on the one hand, the persistent use of Latinized versions is firmly linked to the medium where they initially occurred (i.e. electronic communication), including all connotations surrounding the medium and its users. On the other hand, they occur in transnational and diaspora contexts, be it due to technical constraints or "other reasons, such as convenience, convention, audience considerations or literacy competence". ${ }^{34}$ At least in the first case, the simultaneous use of both the native and the Latin script for rendering the native

Mediated Communication 9(1), 2003), Russian (Birzer, Sandra: Transliteracija russkich grafem $v$ latinicu $v$ èlektronnoj perepiske na russkom jazyke. Izdatel'stvo SanktPeterburgskogo Universiteta: Sankt-Peterburg 2004), and Bulgarian (Kirova, Ljudmila: „Bilingvizăm i digrafija v rečta na bălgarskite gejmări”. LiterNet 2001(8), 2002, Staljanova-Michajlova, Nadežda / Genev-Puchaleva, Ilijana: „Kirilica i/ili 'metodica' v bălgarskoto elektronno obštuvane”. Południowosłowiańskie zeszyty naukowe: Język, Literatura, Kultura 3, 2006, pp. 211-218, Kempgen, Sebastian: „Handschrift, Web 2.0 und Paläographie”. In: Symanzik, Bernhard (ed.): Miscellanea Slavica Monasteriensia: Gedenkschrift für Gerhard Birkfellner. LIT: Berlin, Münster 2013, pp. 327-333).

32 One of the most important tools is http://translit.net/.

33 Androutsopoulos 2009, p. 225.

34 Androutsopoulos 2009, p. 227 who also reports that Greeklish is the default choice for second-generation Greeks in Germany when engaging in electronic communication (ibid.). 
language in computer-mediated interaction ${ }^{35}$ has provoked intense public discussions (both between Internet users and in "traditional" media) about increasing Latinization being a threat to national identity. ${ }^{36}$ Within immigration contexts, to which we turn now, the substitution of Cyrillic characters by the Latin alphabet might be linked to other factors as well: The most important factor is a possible lack of literacy in the home language, at least for those users who were already born in the host country or immigrated with their parents at a very early age, i.e. before entering school in the home country. In these cases, the acquisition of literacy in the home language often depends on voluntary efforts on the side of the children and/or their parents, which some families may not be able to afford. ${ }^{37}$ Furthermore, even in the case of successfully acquired biliteracy, there is a lack of possibilities to use this proficiency in everyday life. Computer-mediated communication with relatives and friends in the home country or within (trans)national diasporic networks provides one of the very few possibilities to practice writing skills in the home language.

\section{Data collection and research questions}

The data for the current study were gathered in the social network StudiVZ. Unlike its global counterpart Facebook, StudiVZ ${ }^{38}$ (= German abbreviation for Studentenverzeichnis 'Students' Directory') is a social networking platform that specifically addresses college and university students who live in a German-speaking environ-

35 Androutsopoulos 2009, p. 222 uses the term „computer-mediated digraphia“ to capture the parallel use of Greek and Latin scripts in the same domains of electronic communication in Greek.

36 See Androutsopoulos 2009, pp. 225 f. for an extensive treatment of the public debates surrounding "Greeklish" in the late 1990s. The same equation of Latinization with a supposed national threat can be seen on the Russian Internet, when entering search terms such as "Latinization of Russian" (latinizacija russkogo jazyka). This "phobia" is reinforced by the observations of many Russians about the spread of Latin script into off-line public discourse: mainly single words written in Latin characters on public billboards, advertisements and in newspaper articles, but also graphic hybrids like Armozona 'Auto Zone'. This tendency is often linked to an increased amount of loanwords and borrowings from English entering Russian after the Perestroika (cf. Grigor'eva, Tat'jana Michajlovna: Tri veka russkoj orfografii (XVIII-XX vv.). Izdatel'stvo Ėlpis: Moskva 2004, pp. 238-240).

37 This might involve time-consuming training of the children to read and write the home language, or attending classes of heritage language schools ("Sunday/Saturday schools", when locally available).

38 Website: www.studivz.net. 
ment (Germany, Austria, Switzerland). It was launched in November 2005 and rapidly developed into one of the most successful online media in Germany. The platform reached its peak in November 2009 with 6.2 million registered users. ${ }^{39}$ Due to its success, similar versions were launched that focus on secondary school students (SchülerVZ, February 2007 - April 2013) and non-students (meinVZ, since February 2008). As of 2010, all VZ Networks together claimed a total user base of over 16 million users. However, the numbers started to drop already in 2009, with the global competitor Facebook surpassing the VZ networks in the number of registered account holders in Germany since April 2011. In August 2012, only 519,000 visitors of StudiVZ were counted. Despite this rapid decline in popularity, StudiVZ was chosen as the source for data collection precisely because of its decidedly German character. ${ }^{40}$ This gives a degree of certainty that the users with Slavic background who engage in the group discussions live in a German-speaking environment, and thus can be considered to have at least some proficiency in German. The same can be assumed with regard to the overwhelming majority of their audience.

StudiVZ provides its registered members a lot of features that are comparable to other social networking sites. For the purpose of the current study, the function allowing every registered member to organize a group on a specific topic is of special importance. These groups have their own pages and offer discussion forums with different threads that are open to all group members. By browsing through the list of groups, one encounters a huge number of groups that obviously target an audience with biographic roots outside of the German-speaking area. This orientation towards users who share a common cultural and/or linguistic background is often directly reflected in the groups' names: Made in CCCP, Made in USSR', Russen ,Russians', Ukrainci v Berlini - Ukrainer in Berlin ,Ukrainians in Berlin', HRVATSKA-moja domovina ,Croatia - my homeland' etc. These groups and the discussion forums they provide mostly revolve around topics related to political and cultural events in their home countries, or to the situation and life

39 All figures provided in this section were taken from http://de.wikipedia.org/wiki/ StudiVZ (last accessed August, 14, 2014). Between 2006 and 2009 similar services were available in France (StudiQG), Italy (StudiLN), Spain (EstudiLN) and Poland (StudentIX), but these international offshoots were given up in January 2009. Since then, the focus has been on students in German-speaking countries.

40 Data collection took place between April and September 2012 during a fellowship at the Freiburg Institute for Advanced Studies (FRIAS) of the University of Freiburg. I am very grateful to Peter Auer and Juliane Besters-Dilger for inviting me to FRIAS and granting me the possibility to work on this project. 
of the respective ethnic and/or linguistic community in the host countries Germany, Austria or Switzerland, including questions of inter-ethnic relationships. Transnational diasporic relations are almost never addressed, which clearly shows the local base of the users. Another factor that contributes to this local character is language use. Generally speaking, the discussion forums mirror language preferences of its members, ranging from posts exclusively written in the Slavic home language, to messages written only in German. Furthermore, various types of code-switching and code-mixing including languages other than the Slavic home language and German, can be observed. ${ }^{41}$ This makes these groups a very interesting object for studying multilingual, but also multiscriptural practices of their members. Although precise sociolinguistic information about the individual users is, of course, missing, we can deduce the typical profile of a member of these groups by following some of the core participants who show up in different groups related to the same cultural or linguistic background. Since all of these groups provide discussion threads where members can share their individual stories with other co-members, it becomes evident that the average group member represents the second generation of immigrants from the respective countries of origin. Most users claim that they were either born in the host country or entered a German-speaking environment before puberty. ${ }^{42}$ However, there are also a few first-generation immigrants who finished their schooling in their respective home countries, along with occasional native German participants who are - for various reasons - interested in Slavic cultures or languages.

For the current study, I examined groups that target an audience with roots in Slavic countries, whose languages are normally written using the Cyrillic script: Russia, Ukraine, and Bulgaria. Table 1 displays the groups that were selected for analysis, the number of registered (but not necessarily active) members, the

41 Cf. Brehmer, Bernhard: „Sprachwahl und Sprachwechsel in der slavisch-deutschen bilingualen Internet-Kommunikation". In: Kempgen, Sebastian et al. (eds.): Deutsche Beiträge zum 15. Internationalen Slavistenkongress Minsk 2013. Otto Sagner: München, Berlin, New York 2013, pp. 79-88.

42 It goes without saying that there is no way to check whether this kind of personal information is true or not, bearing in mind that fake identities are often said to be typical for anonymous Internet discourse where users in general resort to nicknames for self-presentation. However, since these groups are meant to address people from a certain background (and Slavic cultures and languages are generally not considered very prestigious by members of the German-speaking host communities), there is, to my mind, no reason to substantially question the authenticity of the personal information given by the users themselves. 
number of discussion threads, and the overall number of posts. The last column indicates the number of posts that were included into the analysis, amounting to about 1,500 posts for each of the three examined linguistic groups. ${ }^{43}$

Tab. 1: Overview of selected groups and number of analysed posts

\begin{tabular}{|c|c|c|c|c|}
\hline GROUP & USER & THREADS & POSTS & CORPUS \\
\hline RUSSEN ,Russians & 2,613 & 539 & 13,564 & 1,007 \\
\hline РУССКИЕ СТУДЕНТЫ ,Russian students‘ & 2,278 & 213 & 2,846 & 494 \\
\hline UKRAINE - УКРАИНА ,Ukraine & 1,640 & 378 & 4,670 & 1,031 \\
\hline УКРАЇНА ,Ukraine & 200 & 32 & 157 & 150 \\
\hline MADE IN UKRAINE & 333 & 23 & 134 & 134 \\
\hline UKRAINE THE BEST & 239 & 38 & 204 & 196 \\
\hline BULGARIEN ,Bulgaria & 1,871 & 515 & 15,436 & 1,012 \\
\hline $\begin{array}{l}\text { МИЛА МОЯ, РОДИНО! , My dear, } \\
\text { (my) Homeland!‘ }\end{array}$ & 160 & 23 & 100 & 100 \\
\hline
\end{tabular}

As a first step, I investigated the distribution of messages regarding the languages represented in the posts. The ratio of posts that were exclusively written in the Slavic home language varied between $65.6 \%$ (Bulgarian groups) and $40.1 \%$ (Ukrainian groups), thus indicating a relatively high loyalty towards the Slavic home languages if compared to the web presence of other immigrant groups in Germany (see Brehmer 2013 for details). If all posts that contain at least a single element in the Slavic home language - which is inserted into a German (or English) base text - are taken together, the ratio of these posts rises to $79.3 \%$ (Bulgarian), $56.3 \%$ (Russian) and $48.0 \%$ (Ukrainian), respectively. ${ }^{44}$ In Brehmer (2015), I examined the ratio of messages where Slavic passages are written in Cyrillic, as compared to the number of posts where the users resort to Latin characters for rendering the Slavic parts of their message. It turns out that between $69.7 \%$

43 The criteria that were applied for selecting the groups and the posts are explained in Brehmer, Bernhard: „Script-Switching und Digraphie im Netz: Schriftpräferenzen und Schriftkontakt in der bilingualen deutsch-slavischen Internet-Kommunikation". In: Tomelleri Vittorio/Kempgen Sebastian (eds.): Slavic Alphabets in Contact. Bamberg University Press: Bamberg 2015, pp. 59-94 and Brehmer 2013 in detail. Due to a lower number of groups that target a Bulgarian-speaking audience, the Bulgarian subcorpus turned out to be slightly smaller than the Russian and Ukrainian subcorpora.

44 Cf. Brehmer 2015. 
(Bulgarian) and $50.2 \%$ (Ukrainian) of the posts containing at least one insertion in a Slavic language show the use of Cyrillic script. However, the use of Cyrillic characters clearly depends on the length of the insertions in the Slavic home languages. The more Slavic elements a post contains, the higher the probability that the user resorts to Cyrillic script for rendering Slavic passages in his/her post. This tendency is valid for all three linguistic groups ${ }^{45}$ Furthermore, some users quite consciously apply different scripts in their messages: While in most cases, script-switching is bound to the alternation of languages in the message (Slavic parts - Cyrillic, German/English parts - Latin), both scripts are sometimes used as contextualization devices, even in cases where the whole contribution is written in Slavic. ${ }^{46}$

For the current study, I concentrated on the analysis of stretches of metalinguistic discourse regarding the use of Cyrillic and/or Latin script for writing the Slavic home language, which sporadically show up in the analysed posts. Thus, the main research questions to be dealt with in the following sections will be: (1) Is the use of Cyrillic script treated as an emblematic boundary marker within corporate self-presentation that differentiates between "real“ Slavic (in-group) and "Germanized" Slavic (out-group) members? How do the users perceive the use of the Latin script to render Russian, Ukrainian or Bulgarian? (2) Do the three examined groups differ with regard to considering the Cyrillic script an identity marker?

\section{Results}

\subsection{Some general observations on debates about script choice in StudiVZ}

Before analysing the metalinguistic discourse surrounding script choice that unfolds in single discussion threads of the selected groups, some general remarks about attitudes towards scripts in StudiVZ should be made. First, the fact that script choice seems to bother people is already indicated by some group names that explicitly refer to knowledge and/or (ab)use of Cyrillic script in the social network: Ich kann kyrillisch! ${ }^{47}$,I know Cyrillic' (German), Gegen kyrillisch in

\section{Cf. Brehmer 2015.}

46 See Brehmer 2015 for details.

47 All names are given in their original orthographic form. For readers who are not familiar with the languages under focus, the language is indicated in brackets after the English translation of the name. 
deutschen VZ-Gruppennamen, Against Cyrillic in German names of VZ-groups (German), Венн ду дас лезен каннст, If you can read this' (German), Аз пиша на кирилица! ,I write in Cyrillic' (Bulgarian) or Български на кирилица, Bulgarian in Cyrillic' (Bulgarian). While the first three groups actually address all StudiVZmembers who have (n)ever acquired the Cyrillic script in their life, independent of a certain ethnic or linguistic background, the latter two seemingly attribute a symbolic value to the use of the native Cyrillic script for writing Bulgarian in forums of StudiVZ. However, these two groups have hardly attracted any members, and consequently did not provoke any discussion regarding their topic. This observation mirrors the fact that metalinguistic discussions about script choice for writing the three languages under focus exclusively occur in the groups addressing an audience with Russian cultural background. While questions concerning language choice for contributing messages to the discussion threads figure prominently in the examined Bulgarian and Ukrainian groups as well, almost no explicit attention is paid to script choice when posts are delivered in the Slavic home language..$^{48}$ Thus, already at this stage of the analysis, we can conclude that script choice stipulates metalinguistic discussions only in the Russian groups. We can only carefully speculate about the reasons for this general result, especially if we take into account the rather limited amount of groups and posts that were included into the analysis. For the Bulgarian groups, one possible reason for the absence of metalinguistic discussions regarding script choice could be the high share of posts written in the Cyrillic script (69.7\%, which is the highest score for all three selected linguistic groups). Thus, messages where passages in Bulgarian are rendered in Latin characters occur rather sporadically, which offers fewer possibilities to attack the "abuse" of the Latin script. ${ }^{49}$ More importantly, the members of the Bulgarian groups seem to represent a different immigration profile as compared to the Ukrainian and Russian groups. The proportion of first-generation immigrants who came to Germany before entering university (especially after Bulgaria had joined the European Union in 2007) is seemingly higher than in the

48 The only instances of emblematic usage of the Cyrillic script can be found in the design of screen or user names. Here, some users tend to display an affiliation to Bulgarian culture and Bulgarian identity by introducing (parts of) their names in Cyrillic, e.g. the maiden name: Vania Neumann geb. Джуркова 'Vania Neumann, nee Džurkova' (see Brehmer 2013).

49 However, the rather small differences regarding frequency of Cyrillic script use between the Bulgarian (69.7 \% of all posts in Cyrillic) and Russian groups (63\%) are not sufficient to explain the differences in reacting to Latin-alphabet posts, as was rightly stated by one of the reviewers of this paper. 
other two linguistic groups. ${ }^{50}$ Thus, using Latin script for rendering Bulgarian is obviously not so much linked to a presumed missing alphabetization in the home language, but rather reflects the symbolic connotation of Latinica as being the script of the Internet (see section 3 above). The absence of script debates in the groups addressed to an audience with Ukrainian background is harder to explain. Given the lively debates about language choice in the investigated groups, it seems to be that script choice is simply a matter of secondary importance for most of the users, if compared to the problem of whether to choose Ukrainian, Russian or "neutral" German for posting messages. ${ }^{51}$

Another factor that limits variation in script choice are attempts of "organized management" on the part of group administrators who try to regulate the use of languages and scripts by group members. ${ }^{52}$ Thus, some group administrators formulate rules that group members in the discussion threads are supposed to obey. These rules also often refer to issues of language and/or script choice. To quote just one example: Rule 3 imposed by the administrators of the group Are you gangsters? - No, we are Russians reads as follows: "Please write in German or Russian: Russian written with German letters is often incomprehensible; therefore, please use translit.ru or comparable tools if you do not have a Russian keyboard"53. However, a lot of users neglect these rules, which sometimes leads to the elimination of Russian messages in Latin script by the group's administrators. This again often provokes harsh responses by other users, who view these actions as abuse of administrative power, and announce that they will resign from the group if

50 Immigration from the successor states of the former Soviet Union to Germany (especially from Russia, Kazakhstan and the Ukraine) reached its peak shortly after the dissolution of the Soviet Union in the early 1990s, cf. Brehmer, Bernhard: „Sprechen Sie Qwelja? Formen und Folgen russisch-deutscher Zweisprachigkeit in Deutschland". In: Anstatt, Tanja (ed.): Mehrsprachigkeit bei Kindern und Erwachsenen. Erwerb, Formen, Förderung. Attempto: Tübingen 2007, pp. 163-185.

51 See Brehmer 2013.

52 Cf. the distinction between "simple management" of linguistic issues, which manifests itself in self- or other-corrections of forms in face-to-face communication, and "organized management", which is implemented by social organizations from above, in Language Management Theory (Jernudd, B.H. / Neustupný, J.V.: „Language planning: for whom?" In: Laforge, L. (ed.): Proceedings of the International Colloquium on Language Planning. Les Presses de L’Université Laval: Québec, pp. 69-84). Instances of simple management will be dealt with in the following section.

53 For reasons of space, all quotes here and in the following section will be presented in English translations only. All translations are mine. The last names of the users are reduced to their initials to ensure anonymity. 
this practice continues. These exchanges often form the starting point for metalinguistic debates about the legitimacy of using Latin characters to render posts in Russian. These debates will be analysed in the next section.

\subsection{Metalinguistic debates about script choices in the examined Russian groups}

Many core users of the investigated groups never resort to Latin script for posting messages in Russian, but rather use Cyrillic consistently. Others alternate between Latin and Cyrillic scripts, some of them dependent upon the language of the post, some use both scripts even when writing Russian. ${ }^{54}$ However, there is a third group of users who obviously feel more comfortable sticking to the Latin alphabet for Russian posts. This practice often stimulates spirited discussions among group members which are clearly shaped "by a 'polarization of the community', in which different 'schools of thought' collide" (Mitra 1998, p. 64). ${ }^{55}$ Sometimes, the issue of script choice even forms the topic of whole threads. Thus, the thread "Abstimmung: Russisch mit deutschen Buchstaben schreiben?" (Voting: Writing Russian with German characters?) in the group Russen 'Russians' is dedicated to an exchange of views among group members debating whether it is legitimate to use Latin script for rendering Russian posts. I will focus on the debate in this thread in more detail since it contains the whole range of arguments which are raised in favor and against the use of the Latin script for writing messages in Russian.

A clear majority of users who take part in this discussion does not meet the use of Latin characters with approval. Some of them even go so far as to mobilize the knowledge and use of the Cyrillic script to index boundaries within the Russianspeaking community of the forum: Stanislav S. formulates this ideological view on script choice succinctly by stating that "Russians should write in Russian!", where 'Russian' here obviously is meant to refer to the use of the Cyrillic script. Artem S. also explicitly ethnicizes matters of script choice: "Repatriates ${ }^{56}$ considering

54 See Brehmer 2015.

55 Mitra, Ananda: „Virtual commonality: Looking for India on the Internet”. In: Jones, Steven G. (ed.): Virtual Culture. Sage: London 1998, pp. 55-79, cited by Androutsopoulos 2006, p. 536.

56 'Repatriates' (Russian pereselency, German (Spät-)Aussiedler) here refers to the group of immigrants from countries of the former Soviet Union who could claim German descent, owing to the fact that their ancestors immigrated from the German lands to Russia in the $18^{\text {th }}$ century or later, and were therefore granted German citizenship right after immigration in the late 1980s and 1990s. Their dominant home language in 
themselves as Russians do not know Russian. They write in a Latinized version, but in an incredibly skewed one." Here, a division is made between "real" (ethnic) Russians who are supposed to know Russian and to write it properly (i.e. using the Cyrillic script), and some "Pseudo-Russians" who claim to have a Russian identity, but are not able to use the corresponding identity markers, e.g. the Cyrillic script. An immediate link between proficiency in Russian and knowledge of Cyrillic as an inalienable part of Russian language competence is also emphasized by other members, e.g. by Natalie Z.: "If a person claims that he knows a language, this means that he can speak it, read it and WRITE it! And to write Russian means to write in Cyrillic." Others perceive a missing knowledge of the Cyrillic script as a "lack of education" (which means that all users who use the Latin script for writing Russian are considered to be "mentally retarded"), or stress the role of Cyrillic as an untouchable symbol of Russian cultural heritage. An anonymous user puts it as follows: "Language figures as a carrier of any culture. If you don't know a language you belong to the respective culture only partially, if at all." Thus, not knowing the Cyrillic script is considered by some users to be a 'betrayal' of Russian ethnic or at least cultural and linguistic identity. Following Androutsopoulos ${ }^{57}$, we can classify these opinions expressed against the use of Latinized Russian as "ideological" in nature, where "orthography [and script choices, B.B.] can be seen as the site of potentially intense struggles over identity and power, in which issues like the purpose of literacy and the status of languages are central, and orthographic characters $[. .$.$] may be imbued with a symbolic meaning that makes their phone-$ mic symbolism and learnability of secondary importance." (Sebba 1998, p. 20) ) $^{58}$ Such ideological arguments are also provided by one of the administrators of the group, Violetta S., who uses this and other threads as a platform for defending the anti-Latin script policy that she is trying to impose on the others. She often resorts to script-switching in the opposite direction, i.e. to rendering of German sentences by using the Cyrillic script, to demonstrate that there is an asymmetry between the two scripts in relation to language choice: "Why does no one type German with Russian characters"? Ultimately, this is also used as an argument against the view of some proponents of Latinized Russian that using the Latin script supports the speed and ease of processing Russian posts (see below). She

Germany, at least among the generations that grew up in Soviet times, continued to be Russian. Thus, they form a great part of the heterogeneous Russian-speaking diaspora in contemporary Germany (see Brehmer 2007 for details).

57 Androutsopoulos 2009, p. 222.

58 Sebba, Mark: „Phonology meets ideology: the meaning of orthographic practices in British Creole". Language Problems and Language Planning 22, 1998, pp. 19-47. 
considers Latinized Russian as a mistreatment of the Russian language, and as a lack of respect towards the other users ("treat the Russian language and your interlocutors with respect, you don't distort German by using Cyrillic either"). Other users emphasize aesthetic aspects why Latinized Russian should be avoided: "To read Russian words written in Latin letters is the same as reading something written with shit on a fence: everything seems clear, yet it is somehow unpleasant! So dear fellow countrymen, write in Cyrillic, or at least in German!" (Leonid G.). Even users who support a much more tolerant position towards Latinized Russian agree that Russian written in Cyrillic looks better: "Russian words 'in Russian' certainly look better!" (Anton F.). However, the most commonly uttered objection against the use of Latin characters to represent Russian posts is readability. Opponents of Latinized Russian complain that it is hard to decipher, especially with regard to the different solutions that are used to render Russian sounds that are missing in the German sound system, first of all the various sibilants: "I'm also against it [i.e. Latinized Russian, B.B.] - first, because sometimes the letters 'Ж,Ш,щ,3,ч' are coded in a way that you don't fucking understand what's the word" (Max S.). The lack of a generally accepted transliteration or transcription scheme leads according to the opponents of Latinized Russian to chaos and confusion which hampers efficiency of communication. Difficulty in processing is often documented by quoting posts of users who use rather unusual transliteration or transcription schemes, which forces the readers of these posts to "break their eyes" (lomat' glaza) when trying to read these messages. ${ }^{59}$ This is why some users claim that they refuse to read Latinized Russian posts at all: "I often do not read Russian texts, which are written in Latin script, if they are longer than one line. I don't have enough patience" (Margarita W.). This can be read as a warning to proponents of Latinized Russian that their contributions could be ignored precisely because of the "wrong" script choice - in this case not even language choice, since posts in German are explicitly allowed and recommended if group members lack literacy in the home language. Latinized Russian seems to be increasingly stigmatized by most group members because, in their opinion, all users nowadays have the

59 A typical example for the argument that Latinization impedes readability and therefore effective communication is the message of $\mathrm{Lu} \mathrm{H}$., who first quotes from a preceding post: 'Da priwelegija kone4no ogromnaja 200000 mjortwich w god bes 4e4ni, otkuda ti eto s kopiriwal?^^ A mogu4ij russkij AK -74 ja i bes armii mogu w rukah derschat (Schützenverein), i escho weschi po weseleje!!' and then complains about its poor comprehensibility: "Can anyone read this accumulation of letters? Next time visit www.translit.ru please. You type there, copy it, paste it here. Or write in German. My God, it's impossible to read!" 
technical option of writing Russian messages in Cyrillic characters: "With many more or less new computers one has the option to switch to Cyrillic, and it is possible to get acquainted with the Russian keyboard within two or three weeks" (Margarita W.). Even in cases where the computer offers no technical solution, there is always the option of using transliteration tools that are freely available on the Internet (like translit.ru). Thus, if users do not take advantage of these technical possibilities and still stick to Latinized Russian, this can be considered a kind of laziness or disrespect towards the other users. Androutsopoulos ${ }^{60}$ interprets this kind of argument as an "autonomous" view of script choice, which is "based on the tacit assumption that the mere existence of a technological solution must by itself lead to the disappearance of script variation".

However, not all members show a hostile attitude towards the use of Latin characters for composing Russian messages. One group of participants in this discussion exhibits a tolerant position regarding the use of Latinized Russian. According to their views, script choice is a matter of linguistic freedom that every other member of the group ought to accept: "I somehow don't care.... write whatever you want, if only it is legible" (Aleksandra). The user Saška-Rusalka also supports this pragmatic stance towards Latinized Russian, and even highlights that it is the content that matters, not the external form of the message. Furthermore, even in cases where posts are written in Latinized Russian, it is possible to determine whether the user has grammatical knowledge of Russian or not: "It doesn't matter which characters - Russian stays Russian, and even when someone writes Russian in Latin characters you can tell about his/her grammatical knowledge in Cyrillic [sic!] [...] It is only content that counts." Thus, she rates grammatical attainment higher than knowledge and/or use of the Cyrillic script in assessing proficiency in the home language. Marat S. even explicitly claims the free right to decide about script choice in the forum: "As far as I am concerned, I will not let others prescribe me how I have to write."

The third and smallest group of participants not only supports a tolerant position towards Latinized Russian, but argues for a decidedly positive evaluation of it. It is interesting to note that all advocates of Latinized Russian follow an autonomous approach towards script and orthography, which "views orthography as a 'neutral' technology for the representation of spoken language" ${ }^{\text {" }}$. Unlike the opponents of Latinized Russian, they do not attach symbolic and aesthetic meanings to the use of Latin characters. Their spelling choices are mainly explained by

60 Androutsopoulos 2009, p. 242.

61 Androutsopoulos 2009, p. 222. 
instrumental motivations. While at least some advocates of Greeklish, according to Androutsopoulos ${ }^{62}$, emphasize the medium-related value of the Latin script as the 'code of the Internet', this kind of ideological argument in favour of the use of Latinized Russian is absent from the selected discussion threads. ${ }^{63}$ In our case, users complain about the poor usability of technical resources for typing Russian: "It is very inconvenient and discriminates against all those who do not have a Russian keyboard" (Maxim M.E.). Transliteration tools are deemed useless, since even this technical solution does not work in cases where the user has problems with the basics of Russian orthography: "translit is useless when you don't know the Russian characters and you have forgotten orthography (and this seemingly applies to a lot of us here!)" (Maxim M.E.). A more commonly shared argument among its proponents is that Latinized Russian is easier to read and write than Cyrillic Russian. An anonymous member puts it as follows: "What I want to say is that, for example, I don't read long texts with Russian characters, because it takes too long and is working my last nerve. I can read Russian, though, but not so fast. I get much faster ahead when one writes Russian with German characters. In this case I can read it very fast and very well. Of course there are words that can be hardly written with German characters, but this is rare and these are isolated cases. Then you take yourself more time at this point in order to decipher the word, but in most cases you understand it already from the sentence context." So, at least for some users, Latinized Russian is regarded as more convenient, faster and less demanding than Cyrillic Russian. The arguments of opponents of writing Russian with Latin characters (who claim a loss of processing ease) are countered by hinting at the fact that posts are normally quite short, which should allow every reader to come to terms with their content. Finally, one line of argumentation develops around the fact that there are a lot of group members who have good oral proficiency in Russian, but never acquired reading and writing skills in Russian. A ban on the use of Latinized Russian would, as a consequence, lead to the exclusion of this group from the discussion threads. At least they would be forced to resort to German for contributions to the threads, which would deprive them of any opportunity to practice their reading and writing skills in the home language: "Those who came to Germany at a very early age, don't know Russian letters, but they can speak Russian well or very well. They cannot read pure Russian texts [...] for them it [i.e. Latinized Russian, B.B.] is the only possibility

62 Androutsopoulos 2009, p. 244.

63 All the other arguments for and against the use of the Latin script that are listed by Androutsopoulos 2009, pp. 242-245 for the Greeklish case show up in the metalinguistic debates on Latinized Russian as well. 
to read Russian!! And to communicate in Russian!! And there are quite a few!!” (Maxim M.E.). What these users are trying to do, then, is to disassociate script choice and ethnic or linguistic identity. They refute the hostile evaluations of, and policies directed against, the use of Latinized Russian by claiming it to be a "necessary evil" which allows everyone to take part in the discussions and use the home language for this purpose. No one is discriminated against, since all of the users live in a German-speaking and writing context, and are therefore familiar with the Latin script. Latinized Russian is essentially considered an instrument of getting meanings across, but not as a means of indexing boundaries between different group members.

\section{Summary and conclusions}

Script systems are socially, culturally and historically embedded units of language which can be seen as "the embodiments of [...] practices of choice" ${ }^{\text {" }}$. The most obvious level of choice in a biscriptual (immigration) context is the decision for one particular script system at the expense of another. Here, social meanings that are attached to scripts become especially evident: "Given the possibility of variation, one of the forms is nearly always the standard norm, and alternative forms will be seen as deviating from them." ${ }^{65}$ In a Russian-German bilingual context such as the one we focused on in this paper, variation between Cyrillic and Latin script for rendering messages in the home language Russian is used to represent different cultural orientations of individual groups within the Russian-speaking diaspora in Germany. In our case, it serves to construct boundaries between "ethnic" Russians and repatriates (Spätaussiedler) of German descent, at least from the perspective of some "ethnic" Russians. Thus, the use of Latinized Russian signals social distinctiveness and otherness, but mainly from the perspective of users who seemingly have acquired literacy in the home language, and therefore use the Cyrillic script consistently. Using Latin characters when writing Russian is not seen by these group members as a result of a conscious and meaningful decision on the part of the individual participants of the discussion threads, but mostly as the mere result of lacking literacy, or as an index of low proficiency in the home language. Interestingly, Latinized Russian is not used as a general symbol of a subcultural identity, or a symbol of otherness that marks the boundary between speakers of Russian living abroad and those living in the countries of origin. It is also not used as a symbol of individual multicultural or hybrid identities

64 Sebba 2012, p. 9.

65 Sebba 2012, p. 6. 
independently from language mixing, the only exception being some users who engage in script-mixing in screen names as an emblematic display of their dual identity. Script choice, then, does figure prominently in the self-ascription or selfdisplay of group membership in local or global discourse. However, it is mainly implemented as a resource for explicitly marking the 'we'-code when referring to other users who do not belong to the same group of the Russian-speaking diaspora (which in this case is indicated by their lacking knowledge of Cyrillic).

As can be seen from the metalinguistic debates analysed in the paper, Latinized Russian represents a rich case of aesthetic and ideological conflict. The arguments that are levelled against it combine instrumental (no technological necessity to use it any more, hard to read), aesthetic (looks "ugly") and identity aspects ("real" Russians should write Russian properly, which means that knowledge of Cyrillic indexes in-group membership). Advocates of writing Russian with Latin characters, however, mainly resort to instrumental reasons (technology-related, ease of processing, only way to engage in exchanges conducted in Russian) for their preference, and exhibit an autonomous approach to matters of script choice. While some users challenge the normative, essentialist equation of Cyrillic script, Russian and Russian cultural identity that has to be maintained in the host countries, they never (at least in the analysed discussion forums) draw on the symbolic value of the Latin script as the dominating script of the Internet. This argument only seems to play a role, although rather implicitly, in the analysed Bulgarian groups where metalinguistic debates about script choices are almost absent. Ideological approaches that would treat Cyrillic as a symbol of the home culture never show up in these groups (except in some group names that do not trigger any discussion on this topic). The same applies to groups that address a Ukrainian audience. But even the Russian groups differ with regard to script policy and choice. While some groups explicitly prohibit the use of Latinized Russian, where this ban leads to its thorough absence in the discussion forums, other group administrators are not successful in their "struggle" against it, because some users refuse to obey attempts to prescribe Cyrillic script use for Russian messages. There are also Russian groups where the use of Latinized Russian does not provoke any discussion at all, in contrast to issues of language choice.

We can thus state that - despite the hostile movement against Latinized Russian in some groups - the script policy in social networks addressing a Slavic-German bilingual audience is still in a state of flux. Whether Latinized Russian will survive in these bilingual settings, despite its stigmatization and attempts to 'ethnicize' script choice, remains to be seen. In the light of ongoing language shift toward the majority language German, which especially affects writing and reading skills 
in the home language ${ }^{66}$, it seems plausible to suggest that rendering Russian with Latin characters will continue to function as a visual sign of the symbolic status of Russian as a minority language in the respective host countries. The persistent use of Latinized Russian in transnational communication will definitely support its position in the diaspora.

\section{References:}

Achterberg, Jörn: Zur Vitalität slavischer Idiome in Deutschland. Eine empirische Studie zum Sprachverhalten slavophoner Immigranten. Otto Sagner: München 2005.

Alexander, Ronelle: Bosnian - Croatian - Serbian: A Grammar with Sociolinguistic Commentary. University of Wisconsin Press: Wisconsin 2006.

Androutsopoulos, Jannis: „Networked multilingualism: Some language practices on Facebook and their implications". International Journal of Bilingualism 19(2), 2015, pp. 185-205.

Androutsopoulos, Jannis: „Code-switching in computer-mediated communication”. In: Herring, Susan / Stein, Dieter / Virtanen, Tuija (eds.): Pragmatics of Computer-mediated Communication. de Gruyter: Berlin 2013, pp. 667-694.

Androutsopoulos, Jannis: „'Greeklish’: Transliteration practice and discourse in a setting of computer-mediated digraphia”. In: Georgakopoulou, Alexandra / Silk, Michael (eds.): Standard Languages and Language Standards: Greek, Past and Present. Ashgate: Farnham 2009, pp. 221-249.

Androutsopoulos, Jannis: „Multilingualism, diaspora, and the Internet: codes and identities on German-based diaspora websites". Journal of Sociolinguistics 10(4), 2006, pp. 520-547.

Androutsopoulos, Jannis / Hsieh, Yin Feng / Kouzina, Joanna / Şahin, Reyhan: „Vernetzte Mehrsprachigkeit auf Facebook: Drei Hamburger Fallstudien”. In: Redder, Angelika et al. (eds.): Mehrsprachige Kommunikation in der Stadt: Das Beispiel Hamburg. Waxmann: Münster et al. 2013, pp. 161-198.

Bennett, Brian P.: „Orthography and Orthodoxy in post-Soviet Russia”. In: Jaffe, Alexandra et al. (eds.): Orthography as Social Action. de Gruyter: Berlin 2012, pp. 43-64.

66 Cf. Achterberg, Jörn: Zur Vitalität slavischer Idiome in Deutschland. Eine empirische Studie zum Sprachverhalten slavophoner Immigranten. Otto Sagner: München 2005, p. 146. 
Birzer, Sandra: Transliteracija russkich grafem v latinicu v èlektronnoj perepiske na russkom jazyke. Izdatel'stvo Sankt-Peterburgskogo Universiteta: SanktPeterburg 2004.

Brehmer, Bernhard: „Script-Switching und Digraphie im Netz: Schriftpräferenzen und Schriftkontakt in der bilingualen deutsch-slavischen Internet-Kommunikation". In: Tomelleri, Vittorio / Kempgen, Sebastian (eds.): Slavic Alphabets in Contact. Bamberg University Press: Bamberg 2015, pp. 59-94.

Brehmer, Bernhard: „Sprachwahl und Sprachwechsel in der slavisch-deutschen bilingualen Internet-Kommunikation". In: Kempgen, Sebastian et al. (eds.): Deutsche Beiträge zum 15. Internationalen Slavistenkongress Minsk 2013. Otto Sagner: München/Berlin/New York 2013, pp. 79-88.

Brehmer, Bernhard: „Sprechen Sie Qwelja? Formen und Folgen russisch-deutscher Zweisprachigkeit in Deutschland". In: Anstatt, Tanja (ed.): Mehrsprachigkeit bei Kindern und Erwachsenen. Erwerb, Formen, Förderung. Attempto: Tübingen 2007, pp. 163-185.

Creese, Angela / Blackledge, Adrian: „Towards a sociolinguistics of superdiversity”. Zeitschrift für Erziehungswissenschaft 13, 2010, 549-572.

Cubberley, Paul: „Alphabets and transliteration”. In: Comrie, Bernard / Stone, Gerald (eds.): The Slavonic Languages. Routledge: London 1993, pp. 20-59.

Dale, Ian: „Digraphia”. International Journal of the Sociology of Language 26, 1980, pp. 5-13.

Danet, Brenda / Herring, Susan (eds.): The Multilingual Internet. Language, Culture and Communication Online. Oxford University Press: Oxford 2007.

Dorleijn, Margreet / Nortier, Jacomine: „Code-switching and the Internet”. In: Bullock, Barbara E. / Toribio, Almeida J. (eds.): The Cambridge Handbook of Linguistic Code-Switching. Cambridge University Press: Cambridge 2009, pp. 127-141.

Erfurt, Jürgen (ed.): "Multisprech": Hybridität, Variation, Identität. OBST: Duisburg 2003.

Grigor'eva, Tat'jana Michajlovna: Tri veka russkoj orfografii (XVIII-XX vv.). Izdatel'stvo Ėlpis: Moskva 2004.

Grivelet, Stéphane: „Introduction to: Digraphia: Writing Systems and Societies”. International Journal of the Sociology of Language 150, 2001, pp. 1-10.

Gumperz, John J.: Discourse Strategies. University Press: Cambridge 1982.

Hinnenkamp, Volker / Meng, Katharina (eds.): Sprachgrenzen überspringen: sprachliche Hybridität und polykulturelles Selbstverständnis. Narr: Tübingen 2005. 
Jernudd, B.H. / Neustupný, J.V.: „Language planning: for whom?” In: Laforge, L. (ed.): Proceedings of the International Colloquium on Language Planning. Les Presses de L'Université Laval: Québec 1987, pp. 69-84.

Jørgensen, Normann J.: „Polylingual languaging around and among children and adolescents". International Journal of Multilingualism 5(3), 2008, pp. 161-176.

Kempgen, Sebastian: „Handschrift, Web 2.0 und Paläographie”. In: Symanzik, Bernhard (ed.): Miscellanea Slavica Monasteriensia: Gedenkschrift für Gerhard Birkfellner. LIT: Berlin, Münster 2013, pp. 327-333.

Kirova, Ljudmila: „Bilingvizăm i digrafija v rečta na bălgarskite gejmări”. LiterNet 2001(8), 2002. retrieved from http://liternet.bg/publish3/lkirova/gamers.htm (last access: 15.03.2014).

Koutsogiannis, Dimitris / Mitsikopoulou, Bessie: „Greeklish and Greekness: trends and discourses of 'glocalness'". Journal of Computer Mediated Communication 9(1), 2003, retrieved from http://jcmc.indiana.edu/ vol9/issue1/ kouts_mits.html. (last access: 15.03.2014)

Kronsteiner, Otto: Latinica und Kirilica? Gedanken zu einer entscheidenden kulturellen Herausforderung Bulgariens. Institut für Slawistik: Salzburg 2000.

Leppänen, Sirpa / Peuronen, Saija: „Multilingualism on the Internet”. In: MartinJones, Marilyn / Blackledge, Adrian / Creese, Angela (eds.): The Routledge Handbook of Multilingualism. Routledge: London 2012, pp. 384-402.

Mečkovskaja, Nina Borisovna: Belorusskij jazyk: Sociolingvističeskie očerki. Otto Sagner: München 2003.

Mitra, Ananda: „Diasporic online communities”. In: Christiansen, Karen / Levinson, David (eds.): Encyclopedia of Community. Volume 3. Sage: Thousand Oaks, California 2003, pp. 1019-1020.

Mitra, Ananda: „Virtual commonality: Looking for India on the Internet”. In: Jones, Steven G. (ed.): Virtual Culture. Sage: London 1998, pp. 55-79.

Otsuji, Emi / Pennycook, Alastair: „Metrolingualism: fixity, fluidity and language in flux". International Journal of Multilingualism 7(3), 2010, 240-254.

Palfreyman, David / al Khalil, Muhamed: „A Funky Language for Teenzz to Use’: Representing Gulf Arabic in Instant Messaging". Journal of Computer Mediated Communication 9(1), 2003, retrieved from http://jcmc.indiana.edu/vol9/ issue1/ palfreyman.html (last access: 15.03.2014).

Rampton, Ben. Crossing: Language and Ethnicity among Adolescents. Longman: London 1995.

Sebba, Mark: „Orthography as social action: Scripts, spelling, identity and power”. In: Jaffe, Alexandra et al. (eds.): Orthography as Social Action. de Gruyter: Berlin 2012, pp. 1-19. 
Sebba, Mark: Spelling and Society: The Culture and Politics of Orthography around the World. Cambridge University Press: Cambridge/New York 2007.

Sebba, Mark: „Phonology meets ideology: the meaning of orthographic practices in British Creole". Language Problems and Language Planning 22, 1998, pp. 19-47.

Sinclair, John / Cunningham, Stuart: „Go with the flow: Diasporas and the media”. Television \& New Media 1, 2000, pp. 11-31.

Staljanova-Michajlova, Nadežda / Genev-Puchaleva, Ilijana: „Kirilica i/ili 'metodica' v bălgarskoto elektronno obštuvane”. Południowosłowiańskie zeszyty naukowe: Język, Literatura, Kultura 3, 2006, pp. 211-218.

Wei, Li: „Moment analysis and translanguaging space: Discursive construction of identities by multilingual Chinese youth in Britain". Journal of Pragmatics 43, 2011, pp. 1222-1235.

Wertheim, Suzanne: „Reclamation, revalorization, and re-Tatarization via changing Tatar orthographies". In: Jaffe, Alexandra et al. (eds.): Orthography as Social Action. de Gruyter: Berlin 2012, pp. 65-101.

Woolard, Kathryn / Schieffelin, Bambi: „Language ideology”. Annual Review of Anthropology 23, 1994, pp. 55-82. 


\section{Ethnic boundaries and minorities}





\title{
Lia Melikishvili and Natia Jalabadze
}

(Tbilisi)

\section{Language and Ethnic Boundaries in Multiethnic Georgia}

\begin{abstract}
Der Artikel untersucht die Frage der ethnischen Grenzen im multiethnischen Georgien. Ethnische Grenzen werden hier nicht als territoriale Grenzen verstanden, sondern als subjektiv konzipierte und wahrnehmbare Distanz, welche im Rahmen interethnischer Beziehungen untersucht wird. Sprache als Marker ethnischer Differenz spielt häufig eine wichtige Rolle in Grenzziehungsprozessen. Im Rahmen der georgischen Lebenswirklichkeiten argumentieren wir dafür, Sprache auf zweierlei Arten zu verstehen: einmal als ein Mittel in ethnischen Grenzziehungen und andererseits als ein Medium zwischen diesen Grenzen, welches die Differenzen zwischen ethnischen Gruppen überbrücken kann. Wir zeigen, wie Sprache als Marker ethnischer Differenz für den Erhalt ethnischer Grenzen eingesetzt werden kann.
\end{abstract}

Schlagworte: Sprache als Marker ethnischer Differenz, multiethnische Gesellschaft, ethnische Grenze

Key words: language, multiethnic society, ethnic boundary, boundary maintenance, ethnic marker issue

Georgia is famous for its multiethnic and multicultural composition. Since ancient times, representatives of various nationalities settled in the country. Azeri, Armenians, Greeks, Germans, Jews, Kurds, Ossetians, Russians, etc., lived in this area for centuries, mostly in densely populated enclaves, and sometimes in mixed settlements. In different historical times, the ethnic composition of Georgia changed permanently due to inflows and outflows of various ethnic groups. However, the non-Georgian population (nowadays regarded as ethnic minorities), residing in the area, preserved their ethnic identities, their group's names and self-awareness, their native languages (in many cases), traditional cultures, religions, etc. Through the centuries, the Georgian people have worked out a strategy of peaceful coexistence with different ethnic groups, which implied development of interethnic contacts and interdependence, on the one hand, and maintenance of ethnic boundaries on the other.

J. Chardin, who travelled in Georgia in the second half of the $17^{\text {th }}$ century and visited Tbilisi, commented on Georgia's population: 
"Their manners and customs are a mixture of those of the most of the nations that surround them. This I believe proceeds from the commerce they carry on with many different countries and from the liberty everyone enjoys in Georgia, of living according to his own religion and customs and of freely defending them. Here you see Armenians, Greeks, Turks, Persians, Indians, Tartars and Moscovites..." (Chardin 1815, p. 375).

This short passage outlines multiethnic Georgian society with its existing ethnic boundaries, which, in the words of Barth, "persist despite a flow of personnel across them" (Barth 1969, p. 10).

In this article, we focus on the problem of ethnic boundaries in multiethnic Georgia and the role of language in ethnic boundary-making; regarding the situation in Georgia, we demonstrate how language, as one of the markers of ethnic distinction, could act as a means of maintaining ethnic boundaries.

The issue of ethnic boundaries is a relevant and current problem in multiethnic societies. Ethnic boundaries are generally perceived not as a territorial border, but as a subjectively conceived and perceptible distance, which is considered in the context of interethnic relations. It is a mental product determined by an ethnic group. It serves as a special methodological category in the study of ethnicity and ethnic identity. As noted by Barth, boundaries maintain and generate ethnic diversity within larger, encompassing social systems (Barth 1969, p. 18). According to his assumption, "categorical ethnic distinctions do not depend on an absence of mobility, contact and information, and stable, persisting, and often vitally important social relations are maintained across such boundaries " (op. cit, p. 10). Ethnic boundaries imply cultural and social distance. Cultural distance grows in accordance with social distance. Boundaries may change depending on political and economic conditions, various spheres of social interaction and relationships (Tishkov 1997, pp. 35-38). Markers, the most significant features of a group, operate as boundary-forming and boundarymaintenance concepts. However, not only specific cultural symbols can appear as markers, but also political orientations and values. Language as a marker of ethnic distinction often plays an important role in the process of boundary maintenance.

The problem of communication always occurs in multiethnic regions. It becomes especially problematic in those areas where virtual ethnic boundaries are reinforced by physical isolation of one ethnic group from another. Such situations promote the stability of cultural markers of ethnic identity. For example, in Georgia's southern regions (Kvemo Kartli, Javakheti), ethnic minorities live mainly in compact isolated settlements, preserving their cultural identity and, even more significantly, their native language. Here, language acts as a representation of ethnic identity and ethnic self-awareness.

Generally, language as a social phenomenon could stipulate life without conflicts and peaceful cohabitation of the society. However, it has not always been so in Geor- 
gia, especially during the post-Soviet period, when the language problem in relation to the issue of ethnic boundaries became especially acute.

During the Soviet period, communication between people from different cultural backgrounds generally took place in the Russian language. Russian was the lingua franca among the peoples of the Soviet Union, and that very status was supported by the educational system at that time. "Accordingly, during the Soviet period in Georgia in the areas populated by minorities, the Russian language was also used as a lingua franca." (Melikishvili 2011, pp. 201-203). In the Georgian Soviet Socialist Republic, knowledge of the Georgian language was not a priority for the national minorities, as Russian served as the unifying tongue in majority-minority relations. "General primary and secondary education was available in minority languages, and while higher education was available in Georgian, which was also the official state language in the republic at that time, numerous Russian-language sectors functioned at all higher education institutions of the Georgian SSR" (Mekhuzla/Roche 2009, pp. 5-6).

After the fall of the Soviet Union, Georgia declared independence in 1991 and in 1995 Georgian as a state language (since 1995 by the Constitution of Georgia Abkhazian is a State language of Abkhazia besides Georgian). Restructuring the system on national rails caused serious problems vis-à-vis intercultural communication. By that time, a very small number of the non-Georgian population (residing mainly in compact settlements in the border regions) could speak Georgian; hence, Georgian was unable to function as a common language. Declaration of Georgian as an official language implied its mandatory knowledge primarily by those persons whose work was connected with governmental organizations, various official institutions and medical, educational or other services. Prior to that time, the knowledge of Russian gave additional opportunities for social success to representatives of non-dominant nations, but in post-Soviet times, a lack of command of the Georgian language hampered one's career.

Ethnic minorities who lived isolated in compact settlements in border regions (generally Azeris, Armenians and Greeks) regarded speaking Georgian as coercion. They began to fear being discriminated based upon their ethnic languages, and generally feared oppression and assimilation by Georgians. The language barrier developed into a problem, which was related to the hardships of post-Soviet crisis regarding unemployment, lack of social inclusion, problems of education, etc. This caused common desinterest and frustration among the minorities, and triggered their desire to migrate. The situation resulted in social tensions among them. The Georgian reality has demonstrated that during national revival, a language can obtain the significance of a fundamental ethnic value, and become a means of manipulation of not only cultural, but also political interests. Ethnic clashes occurred here and there, and thou- 
sands of non-Georgians emigrated from Georgia. According to statistical data, nearly half of the ethnic minority population migrated from Georgia in the 1990s. (From urban settlements, the flow of immigrants was directed mainly toward Western Europe and the United States, from the rural settlements mostly to the Russian Federation (Danelia et.al. 2011, p. 8). For example, from Kvemo Kartli region, Azeris migrated mostly to Azerbaijan, Armenians to Armenia and Greeks to Greece, migration flows were directed to other countries, but mainly to Russia (Jalabadze 2011, p. 178).

Those who remained became detached within their communicative space, within their ethnic boundaries; they were separated from the public life of the country, were less involved, and to a certain extent were excluded from the political and social life of the state. In the decades leading up to the "Rose Revolution", the issue caused marginalization of ethnic minorities - they became isolated, relationships between the groups grew tense, and participation in public service were restricted.

As argued by Wheatley, given the weak infrastructural power of the state in the early years of independence (the period of Shevardnadze), it was not possible to promote knowledge of Georgian amongst members of national minorities. Hence, in compact isolated settlements of minorities, knowledge of Georgian remained very poor. As Russian began to lose its role as the language of inter-ethnic communication, the language barrier became increasingly worse between Georgian and minority groups, especially amongst young people. The youth could no longer speak Russian fluently enough to communicate, and programs to teach Georgian to ethnic minorities were half-hearted, mainly due to the state's incapacity to implement its educational policy (Wheatley 2009, p. 14).

After Georgia's Independence, especially since the "Rose Revolution", Russian schools were gradually abolished and transformed into Georgian ones. Very few of them still function in Tbilisi and the State's multiethnic regions. The Russian language teaching hours in secondary schools have been consistently decreasing, and are now minimized (http://saqinform.ge). Russian language media - TV channels and press based in Georgia have been actually decreased to minimum (Akerlund 2012).

For a long period, no program of the universal teaching of Georgian as a lingua franca was instituted. Therefore, until today, the majority of non-Georgians in multiethnic regions are unable to speak Georgian, which prevents successful cross-cultural communication between the Georgian and non-Georgian groups. Those of the elder generations do understand each other because they still use Russian for communication, but children of the younger generation are more alienated.

Due to the lack of command of the Georgian language, compactly settled ethnic minorities are in an informational vacuum. They cannot read the Georgian press and do not watch Georgian TV channels, they are unable to apply to the court or 
the police independently, and very rarely do they continue their studies in advanced Georgian schools, etc. Therefore, they do not understand current or national events. All of the above factors naturally lead to their increasing isolation. The population of mainly isolated monoethnic settlements are oriented towards the neighboring countries - Armenians to Armenia and Azeris to Azerbaijan. One obvious symbol of this outward orientation that immediately catches the eye of a visitor is the mounting of satellite dishes on houses, installed aiming directly toward the neighboring states. Apart from the fact that the ethnic minorities watch foreign TV channels (Azeri, Armenian, Turkish), they identify themselves with a neighboring country, which is linked with the perception of an ethnic, rather than a political border. Irredentist aspirations orient Azeri towards Azerbaijan, Armenians towards Armenia; they link their identity with another state rather than with Georgia. This orientation is not at all desirable for Georgia, and may lead to problems in future.

Under the conditions of independent Georgia following the "Rose Revolution" (2003), the situation has changed and the new strategy of universal teaching of the Georgian language in multiethnic regions has been emphasized. Soon after the revolution, the ministry of education and science of Georgia, in cooperation with international and local experts, issued a special document aiming to create a solid political and legislative basis for the implementation of special programs of Georgian language teaching to the minorities living in multi-ethnic regions. Recently, the State has focused on the problem of harmonization of the education system in order to facilitate verbal communication between different groups (Melikishvili et al. 2011, p. 444).

However, though some progress has been made regarding intercultural communication, the lack of Georgian speaking skills among the population remains a core problem. Among the region's non-Georgian population, mainly minorities living in the capital and multiethnic settlements speak Georgian fluently, while knowledge of the official language is generally very poor in isolated mono-ethnic areas. Fieldwork revealed different situations in different regions regarding Georgian language skills. In the villages inhabited by the representatives of a single non-dominant ethnic group, the knowledge of Georgian is very poor, and in some cases there is no command of the language at all. However, men display better Georgian competence in comparison with women (Jalabadze 2011, p. 205). This applies to all minority groups - Azeris, Armenians, Greeks and others. The situation regarding Georgian language skills is slightly better among women working in regional centres and in the capital, mainly at the markets; this is primarily due to their everyday interactions with Georgians. Generally, they manage to communicate, though their vocabulary is very limited.

In some mono-ethnic settlements, there are Armenian or Azerbaijani schools. In Azerbaijanian and Armenian schools, the Georgian language is also taught. However, 
some places do not have a Georgian language teacher, and if they do, these teachers are often less qualified local staff (Field materials, Kvemo Kartli, 2009).

The language barrier in mono-ethnic settlements in Georgia exists not only because of the lack of Georgian language skills, but because minority groups do not know each other's languages; that is to say, Azeris don't understand Armenians and vice versa, Armenian - Greek, etc. However, in contrast to the isolated compact settlements, the situation is variable in ethnically mixed areas. In the latter, the population understands one another's language and manages to communicate with one another, especially the younger generation, whose contacts are more intensive. For example, there are two villages of Bolnisi in the Bolnisi municipality (Kvemo Kartli region, southern Georgia) located side by side. One is populated by Azeris, and the other by Armenians. According to the information of the locals, the young generation of both villages can speak (though not actively) each other's languages because they have contact in the fields of sports and entertainment. But such situations are comparatively rare.

Aside from the above, it is worth mentioning that the ethnic barriers in the aforementioned societies are strictly limited. It is apparent that, among other reasons, such limits prevent minority groups from integrating into society, which is one of the fundamental prerequisites for the establishment of a civil society. Despite this, from the interviews with our informants it becomes obvious that the Georgian population desires integration of ethnic minorities into the social and political life of the state, and encourages them to study Georgian. According to one of our Georgian respondents: "Azeri and Armenian should learn Georgian because they live here, and they should know the language of the state of which they are citizens. Otherwise, how could they live here?" (Field Materials, Tsalka, 2008) The Georgian population expresses discontent that ethnic minorities do not speak the official language and have no idea about current issues in the country. The following Georgian respondent remarks about their Azeri neighbors:

"They live in Georgia with the life of Azerbaijan. In our village, all Georgians could speak Azeri language but none of the Azeri knows our language. They do not understand the Georgian language and cannot respond. If we learned their language, why don't they do the same? We think that ethnic minorities consider speaking Georgian as something imposed upon them" (Field materials, Dmanisi, 2009).

The fear among ethnic minorities of the violation of "their boundaries" through the imposition of the Georgian language has gradually declined. In the most recent period, ethnic minorities have realized that the lack of knowledge of the state language deprives their children of social and political well-being. Hence, they are more motivated to study Georgian. A young man from an Azeri village remarks: 
"If our people want their children to have a successful future and do not run away from here, they should teach them Georgian. They need to put all the effort in that! Generally, Azeris here have very poor Georgian language skills, because they do not have contact with Georgians. Practice is needed! Only $3 \%$ of the Azeri population could understand Georgian. Therefore, they are mainly engaged in agriculture. If they had a command of Georgian, then why would they go to another country? It makes sense to stay here when you know the State language. Then, we also could find a job as the Georgians do. Georgians work here and we run away either to Baku or to Russia. We have good income there, but we are far from our home. It is better to have 5 Rubles here than 20 in abroad. There you see a little boy- he does not know Georgian, therefore he is unable to get higher education here; he has to go to Azerbaijan. 2000 dollars are needed for his preparation for the exams, and then the exams...?! Those who study in Azerbaijan, will never come back to stay here. Hence, our villages, houses are deserted.

The Georgian Language is taught at non-Georgian schools here, but 5 hours a week is not enough. Everywhere in Europe, in America, everywhere one has to know the language of the country where one lives. Now, all Azeri in Bolnisi, all of us - the young and the adults want to learn the language of the country where we live" (Field materials, Kvemo Kartli, 2010).

Proceeding from the above, teaching the state language to the non-Georgian speaking population is the most important objective for the country's development.

Ethnic boundaries that imply cultural and social distance sometimes do not coincide with political borders of a country; sometimes, ethnic groups with unified identity exist on either sides of a border between two states. This situation is typical for the post-Soviet countries, and especially for Georgia, where the peripheral territories are populated by non-dominant ethnic groups; due to historical conditions, most of these groups have similar ethnic identities to the neighboring states, though they did not come to Georgia from these countries. For example, Armenians of Javakheti resettled not from neighboring Armenia, but from Turkey, while the majority of Azeris migrated from Persia and not from Azerbaijan. The ethnic boundary in the perception of these groups does not coincide with the political one. In this case, the factor of common language and similar culture has played a significant role in triggering irredentist aspirations among these groups. However, such a situation becomes dangerous for the security of a state, especially when ethnic tension occurs.

The self-awereness of the Armenians - residing in Javakheti (South Georgia) near the Georgian-Armenian border - towards this problem is unique. They consider their motherland the region in Georgia, where Armenians live - all Armenian villages, including the regional centre Akhalkalaki. According to their opinion, this area belongs to Armenia. Although they apparently know that they live in Georgia and seem to acknowledge geographic borders, the perception of the motherland 
in their mentality is still entirely different. In interviews they state that the area of their homes is not Georgia, but Armenia. They used to say:

"You see, this is like that in your country - Georgia, but here in Armenia - it is like this." For them, "Your country, Georgia" is the area where Georgians dwell - the territory beyond Akhalkalaki, or sometimes beyond Akhaltsikhe (also with a solid number of Armenians) - while "here in Armenia" is associated with the ethnic boundary and the territory populated by Armenians. This is correspondingly perceived to be the land of Armenia.

The attitude of the Armenian population towards this issue became clear during an interesting meeting with an Armenian woman. When visiting one of the Armenia villages, she almost blocked our way and insisted that we should visit her family - there was no option. We agreed, and she welcomed us with great hospitality. In the end, she finally explained the motives of her behavior. The woman told us:

"I was born and brought up in Georgia, Batumi and then I got married in Armenia. When I saw you, I guessed you were Georgians and I was so happy! My heart fluttered and I decided to invite you to my place by all means."

When we asked her where exactly she was married in Armenia, her answer was"here in this village". We were confused and tried to find out whether she really considered the village to be in Armenia. The woman naively confirmed it without any pretext. The same disposition was present among almost all of our informants.

Myths and tales about the historical location of Armenia are purposefully communicated to the population. In some Armenian families, one will find books describing the origin of Armenia, its lands and owners. The idea of the motherland in the mentality of Armenians is enhanced by covert, and later (after Perestroika) overt anti-Georgian political processes in the region, including but not limited to the promotion of the idea of seceding from Georgia, establishing the region as an independent political unit through a referendum, and later becoming a part of Armenia. The terrorist act against the checkpoint at the Armenian-Georgian border was one outcome of this process. The checkpoint was exploded first in 1990 and then in 1991 due to the assumption that customs controls should not exist in that area at all.

The perception of Javakheti as "the motherland of Armenians" is linked with the fact that many Armenians from the region went to protect "their own land" during the Karabach armed conflict between Azerbaijan and Armenia. ${ }^{1}$ Those who returned proudly established themselves as patriots fighting for their homeland, and were pro-

1 The conflict took place in the late 1980s to May 1994, in the enclave of NagornoKarabakh in southwestern Azerbaijan. At present Armenians fully control most of the enclave and approximately $9 \%$ of Azerbaijan's territory outside the enclave. 
moted to the best positions by local authorities. It is also interesting that many citizens of Armenia who are closely connected with Akhaltsikhe- Akhalkalaki or villages of Javakheti (blood relations, education, and trade) have the same perception - they simply claim that the territory belongs to Armenia.

The aforementioned facts promote the perception of Javakheti as the homeland of Armenians. In the mentality of Armenians living in Javakheti, the conception of the homeland consists of two grades. First, their homeland is the micro-territory where they reside (specifically Javakheti); and secondly, it is Armenia with its currently existing borders.

Despite the fact that attempts are made to promote the idea of "Great Armenia" via the distribution of false maps, an ordinary Armenian farmer still cannot comprehend it. For a local Armenian farmer, the border of his homeland reaches neither Tbilisi, nor Kutaisi, nor the historical region in modern Turkey (though many of them know that they were displaced from Turkey). In the Armenians' mentality, the homeland is the territory where they act - more precisely, where they are entitled to act. The area of intensive activities for the Armenian population in Javakheti has always been, and remains the former Soviet Union (mostly Russia). However, the Armenians have never identified Russia as their homeland. The homeland for them is the place where they were born and where they act; the homeland is the territory settled by Armenians, where they speak Armenian, and it does not matter at all where the politically or historically delineated border lies. The ethnic boundary in their perception is their homeland, which for them is the same as Armenia, and where they speak the same language. In their perception, they thus identify themselves with the population of a different country.

The language as one of the markers of identity could be regarded as the most effective and influential factors in similar situations. However, if on the one hand language as we have shown above acts as a primary marker for ethnic boundary formation, on the other hand it does not operate as a marker of ethnic distinction. This can be observed in case of the Greek population in the Tsalka district (Kvemo Kartli region). Part of the Greek population in Georgia speaks Pontic Greek, and the other part Turkic, an Anatolian dialect of Turkish. The Turkic-speaking group (Urums) would never associate themselves with Turks, despite the similarity of their spoken languages. Both of these groups have Greek ethnic identity; the difference between their languages does not affect their ethnic affiliation. However, the position of outgroups is different. Some Georgians, for example, call them Tatars as their speech is Turkic. Apparently, the outgroup associates language with ethnicity - "if they speak Turkish, they are Turks". 
A similar situation can be observed with the Ajarians, who are Muslim Georgians who speak Georgian. Because of ecological catastrophes in Achara, the affected population migrated to Kvemo Kartli. Hence, they became part of the multiethnic society in the region. Due to their religious orientation, Ajarians are also regarded as Tatars by out-groups; language in this case does not matter at all. In the mental representation of the majority of Georgians, religious affiliation is closely linked to ethnic identity. The Christian faith was equated with Georgian, and Muslim with Tatar (or ethnic groups of Turkic identity). Often, Christian was used as a synonym to Georgian, and if someone was Muslim he was considered to be Tatar. In this society, where such representations are still vital, the notion of Muslim Georgian is difficult to accept. For that reason, Greeks in the Tsalka region do not recognize Adjarians as Georgians; they use to say: "They simply speak Georgian! They only know Georgian, but they are not Georgians"(Field Materials,Tsalka, 2008).

A similar opinion can be heard in an interview with a Greek woman from an ethnically mixed village in South Georgia:

"I tell Ajarians, I respect you because you speak Georgian, but why did you change your faith and convert to Islam? If you are Georgians, you should have nothing to do with Turkey - I said. And do you know, what they answered? If Turkey attacks us, they will kill you, and not us! Hum, they are real bastards! Then why do they live in our Georgia? Go and live in Turkey then!“ (Field materials, Tsalka, 2008).

Concerning the role of language in ethnic boundary maintenance, the situation among Georgian Jews is different. Jews have had a presence in Georgia as far back as the $6^{\text {th }}$ century BC. For Georgian Jews, Georgia became their motherland and the Georgian language their native language. They even developed a Judeo-Georgian dialect - Qivruli, which includes a number of Hebrew words. Georgian is the family language for the Georgian Jews living in Azerbaijan today. It remains the same among emigrated Georgian Jews in Israel even up to now (Moskovich/Ben-Oren 1982, pp. 19-24, Bekker 2014). Obviously, this fact is a perfect example of integration. However, sharing language had no impact upon their boundary-making process. Among the factors that had crucial importance in preserving Jewish identity in Georgia is primarily their religion and traditions.

Another group with Georgian ethnic identity is the Tsova-Tushs, who - aside from Georgian - speak Tsova-Tush or the Batsbi language, which belongs to the socalled Nakh subfamily of the Northeast Caucasian stock, and exists only as a spoken language. Batsbi people use Georgian as their written language. Despite the historical narrative that ascribes the appearance of this group to the Veinakh tribes, part of which were resettled by King Saurmag in the $3^{\text {rd }}$ cent. BC. in Georgia's Eastern 
mountainous region, their ethnic identity is Georgian. Their choice of belonging to Georgia is not based on their spoken language.

The role of language in boundary-forming and boundary maintenance processes can be viewed in two ways: first, as a means of construction of ethnic boundaries, and second, as a medium between these boundaries that bridges the gaps between ethnic groups.

The above examples of the Georgian situation demonstrate these different roles of language in multiethnic societies. In its first function, language either operates as the primary marker of ethnic identity maintenance, such as in the case of Armenian and Azerbaijani groups, or it is absolutely irrelevant in this process, as in the cases of the Jews, Greeks and Batsbi. As a medium between ethnic boundaries, language acquires additional traits of one of the main actors in the processes of integration.

Today, integration of minorities into Georgian society is one of the core problems of the nation's policy. It strives toward effective intercultural communication, which is achieved via verbal contact between the groups. Lack of Georgian language skills, which had previously caused disruption of communication between the groups, is gradually being reduced. Instrumental motivation for the study of the state language is observed among all ethnic groups in isolated compact settlements. This situation will promote movement of different groups across ethnic boundaries, and promote peaceful coexistence of various ethnic groups with their different cultures and religious faiths.

\section{Literature:}

Akerlund, Tobias: Media Situation in Georgia. Ecmi Working Paper \#52, 2012, retrieved 18.03.2015, from http://www.ecmicaucasus.org/upload/publications/ working_paper_52_en.pdf

Barth, Frederick: Ethnic groups and boundaries. Little, Brown and Company: Boston 1969.

Bekker, Moisey: „Judaism in the Caucasus“. Paper presented at the Conference "Religions in the Caucasus", London 3-4 March 2014.

Danelia, Akaki et.al.: Social protection and Social inclusion in Georgia, Executive Summary. The Institute of Social Studies and Analysis (ISSA), European Union 2011, www.issa-georgia.com

Chardin, John: "The travels of Sir John Chardin through Mingrelia and Georgia into Persia". In: Voyages and travels selected from the Writers of all Nations. voll.VII. J. Christie: Dublin 1815, pp. 321-426. 
Jalabadze, Natia: "Specificities of Acculturation in polyethnic Society". In: Melikishvili, Liana et.al. (eds.): Ethnic aspects of social security in polyethnic society. Mstignobari: Tbilisi 2011, pp. 138-234.

Mekhuzla, Salome / Roche, Aideen: National Minorities and Educational Reform In Georgia. ECMI Working Paper \# 46 2009, retrieved 18.03.2015, from http:// www.ecmi.de

Melikishvili, Liana et. al.: Ethnic aspects of social security in polyethnic society. Mstignobari: Tbilisi 2011.

Moskovich, Wolf / Ben-Oren, Gershon: "The Hebrew-Aramaic and Georgian Components in the Spoken Language of Georgian Jews". In: Proceedings of the Eighth World Congress of Jewish Studies. Held at the Hebrew University of Jerusalem, 16-21 August 1981: Division D, 19-24. Jerusalem 1982.

Tishkov, Valery A.: "Identity and cultural boundaries". In: Olcott M.B/ Tishkov, V.A (eds.): Identity and Conflict in Post-Soviet States. Moscow Carnegie Center: Moscow 1997, pp. $15-43$.

Wheatley, Jonathan: The Integration of National Minorities in the Samtskhe-Javakheti and Kvemo Kartli provinces of Georgia, Five Years into the Presidency of Mikheil Saakashvili. ECMI working paper 44, 2009, retrieved 18.03.2015, from http://www.ecmi.de.

\section{Corpora:}

Field materials, Dmanisi, 2009

Field material, Kvemo Kartli $2009+2010$

Field material, Tsalka, 2008. 
Maria Klessmann

(Frankfurt/Oder)

\title{
Roma school mediation in Germany - Its Effects and Limitations
}

\begin{abstract}
Im Rahmen der von der EU erklärten „Dekade der Roma-Integration“, wurde im Jahr 2011 das Roma-Schulmediatoren-Programm ROMED ins Leben gerufen. Der vorliegende Artikel möchte hierzu Hintergrundinformationen zu der Umsetzung des Programms in Deutschland, dessen Wirkungsweisen und Grenzen aufzeigen und die - teils nicht eindeutige - Rolle der Mediatoren/innen näher in den Blick nehmen. Es gilt also zu fragen, warum es ein auf eine ethnische Minderheit zugeschnittenes Programm dieser Art gibt? Inwieweit es sich dabei um (klassische) Mediation handelt? Und welche diskursiven Rollenzuschreibungen sich welchen Selbstpositionierungen in den (Mediations-)Gesprächen gegenüber sehen? Diese Annäherung erfolgt einerseits anhand gesammelter Aussagen von Verantwortlichen, die mit und in dem Programm arbeiten, und andererseits entlang kurzer Ausschnitte aus dem bisher gesammelten empirischen Material für eine größere Studie, die interessante und auffällige Phänomene für das Thema dieses Artikels enthalten.

Schlagworte: (Roma-)Schulmediation, Minderheit, Ethnisierung, Rollenzuschreibungen, Selbstpositionierungen
\end{abstract}

Keywords: (Roma) School mediation, minority, ethnicization, role assignments, self-positionings

\section{Preface}

There is hardly any reliable data on the school situation of Roma children in Germany. The few existing studies show that Roma children suffer from experiences of discrimination in schools and struggle with high dropout rates, poor qualifications and irregular school attendance. ${ }^{1}$ German politics concerning Roma focus on access to education, access to employment, as well as to healthcare and housing. ${ }^{2}$ As Ger-

1 Like for example the study of Daniel Strauß „Studie zur aktuellen Bildungssituation deutscher Sinti und Roma. Dokumentation und Forschungsbericht" which has been published in 2011 and already in the preface criticizes that it is the first study on this subject since 30 years.

2 Bundesministerium des Innern (Ed.): Report from the Federal Republic of Germany to the European Commission. An EU Framework for National Roma Integration Strategies up to 2020 - Integrated packages of measures to promote the integration and participa- 
many does not compile any statistics about ethnicity, there are no reliable figures on how many Roma live in Germany, how the different origins are distributed among the Roma population in Germany, etc. For larger German cities such as Berlin, it is known that a majority of the Roma population is concentrated in districts which are among the poorest of those cities, but which "provide the informal accommodation structures for newcomers that are typical for such neighbourhoods. ${ }^{\text {"3 }}$

Because in many countries Europe's largest minority is still facing above-average poverty and discrimination, the EU declared a „Decade of Roma Inclusion“, in which many new projects were established to improve the situation of Roma. It was within this context that the Roma school mediators programme (ROMED) was established in 2011. Even prior to that training and employment of Roma mediators or assistants had already started in the 1980s and 1990s at the initiative of NGOs in countries like Spain, France, Finland and Romania. ${ }^{4}$

Based on official documents of the programme ROMED, statements of involved officials, an expert interview with one of the initiators of the programme in Berlin, and empirical data collected for a broader study within German schools, this article provides a first look at the work of Roma school mediators in Germany, its effects and limitations, and discusses some critical points in the everyday situation in German schools. ${ }^{5}$ Why is there a programme tailored to one single „ethnic group“? How does it work? What does it have to do with mediation? Is the heterogeneity of the group conceptualized in the programme, and if so, how does it influence the work of the mediators? Besides these guiding questions, different ideas towards mediation forming the everyday practice of the Roma school mediators is discussed, along with its ideas of the role of the mediators.

tion of Sinti and Roma in Germany. 2011, pp. 5-6, retrieved 30.11.2014, from http:// ec.europa.eu/justice/discrimination/files/roma_germany_strategy_en.pdf

3 Schmitt, Anna/Bytyci, Hamze/Heine, Wolfgang: EUROCITIES report: The Berlin mobile contact point for EU migrant workers and Roma from the perspective of the service providers. 2011, retrieved 30.11.2014, from http://nws.eurocities.eu/MediaShell/media/EURO CITIES\%20report\%20-\%20Contact\%20point\%20for\%20Roma\%20in\%20Berlin.pdf

4 Rus, Calin: The situation of Roma School Mediators and Assistants in Europe, 2006, p. 8, retrieved 30.11.2014, from http://www.coe.int/t/dg4/education/roma/Source/Mediators_Analyse_EN.PDF

5 This article is part of the $\mathrm{PhD}$-project „Negotiating membership in Roma school mediation“ which is condcuted at the graduate school „Perceiving and negotiating borders in conversations“ at the Viadrina Center „B/ORDERS IN MOTION“, Frankfurt (Oder). 


\section{Roma school mediation in Germany}

School mediation is a so-called academic method of conflict settlement, and was implemented in the early 1990s in Germany. Today, almost all German Federal States work with school mediations, at least as a pilot project. ${ }^{6}$ Peer mediation, where students are trained as mediators, but also teachers and sometimes even parents and principals can take part in training courses, is currently the most common form of school mediation in German schools. ${ }^{7}$ Whereas the mediation we talk about here is characterized by the use of a third party which in most cases until then did not belong to the school system.

One of the main ideas of school mediation through the use of third parties or peer mediation is, that it should ideally ease the burden on teachers, as they no longer have to constantly appear as arbitrators. ${ }^{8}$ But, if mediation is successfully implemented in schools, this may also strengthen social skills, such as empathy, team work and communication. If the students learn to resolve conflicts by themselves, this may contribute to an increased self-esteem, as the children and young people no longer appear only as "problem-causers", but also as "problem-solvers“. ".Successful mediation shifts competences, creates a feeling of responsibility among pupils, reduces the power differential between teachers and students and decreases the fear of conflicts and the perception of discrepancies. "10 As Schubarth and Simsa put it, school mediation has the following advantages in comparison to traditional conflict resolutions: Common or traditional ways of solving conflicts usually seek a guilty party, and, in the end, produce winners and losers. In contrast, school mediation is characterized by equality, participation and the mutual consent of interests. Differing points of view and different interests are accepted.

The European Training Programme for Roma Mediators (ROMED) started in 2011 in 15 European countries, and expanded to be implemented in 2012 in

6 Cf.: Simsa, Christiane/Schubarth, Wilfried (Eds.): Konfiktmanagement an Schulen Möglichkeiten und Grenzen der Schulmediation, Deutsches Institut für Internationale Pädagogische Forschung: Frankfurt am Main 2001, p. 3.

7 A lot of literature concerning school mediation in Germany refers (also) to peer mediation as it is currently the most common form of school mediation in Germany.

8 Cf.: Simsa/Schubarth, p. 4.

9 Cf.: Simsa/Schubarth, p. 5.

10 Dittman, Jörg: „Zur Evaluation von Mediationsprojekten an Schulen“ In: Simsa, Christiane/ Schubarth, Wilfried (Eds.): Konfiktmanagement an Schulen - Möglichkeiten und Grenzen der Schulmediation. Deutsches Institut für Internationale Pädagogische Forschung: Frankfurt am Main 2001, p. 68. (Translation M.K.). 
20 countries. According to the latest official numbers, today about 1000 active mediators work in 22 European countries. ${ }^{11}$ Currently, about 10 Roma school mediators are working in Berlin schools; throughout Germany, between 30 and 50 mediators work specifically for members of the Roma ethnic minority. Most European countries use the term „Roma Teaching Assistant“; only seven European countries including Germany use the term Roma school mediation, whereas in Hamburg, for example, the project participants are called „Bildungsberater", which may be translated as "educational advisor." This indicates the wide range of ideas which are connected with this programme and concept of work. The training and deployment of Roma school mediators in Europe is mainly based on the following arguments: especially low educational achievements of Roma in the European comparison, low participation in early childhood education, higher dropout rates and over-representation in special schools or other forms of educational segregation.

Trained mediators are mainly people with a „Roma background“, people of local Roma communities, or even non-Roma with very good knowledge of "Roma issues", the local communities and their languages. Why especially members of the same ethnic minority are designated as school mediators is justified by the fact that "[t]hey understand both the culture and way of life of Roma communities and the way mainstream society and local administrations operate - and they know how to communicate with both." ${ }^{12}$ Part of the work of the Roma school mediators also includes very practical support in everyday life. For example, clarification of what the children need for school and where you can conveniently get school supplies. Another important aspect is the function as "door opener" and translator. Frequently, Roma mediators have better and faster access to the children's parents or families. It is also about monitoring and preparing home visits and interviews of teachers with parents. Roma mediators should aim to improve the attitudes of parents towards education, if necessary. This can, for example, mean improving the school attendance of children.

The programme has now been launched into the second phase. In Germany ROMED2 started at the beginning of 2015 and henceforth also coordinates socalled Community Action Groups. Thereby, the focus is not on the single mediation, but on building networks and communication structures between members

11 ROMED: About Romed, 2014, retrieved 30.11.2014, from http://romed.coe-romact.org/

12 Kyuchukov, Hristo: Roma school mediators in Berlin. Commissioned by the RAA Berlin, Sponsored by the Freudenberg Foundation, 2011, retrieved 30.11.2014, from http://www.raa-berlin.de/Neu2011/PDFDatein/Kyuchukov,\%20Roma\%20School\%20 Mediation\%20evaluation\%20report.pdf 
of Roma communities and local authorities. These groups are being counselled and supported to spell out specific needs and projects which have been identified as important for their particular local groups. After elaborating the projects and ideas of the different members of the Action Groups, meetings with representatives of the city or district are arranged. This second phase is, therefore, also very problem-oriented and searching for a consensus concerning the realization of specific projects resulting from this process. In order to counter-act a possible imbalance of power when the local authorities are the decision makers, the Community Action Groups prepare themselves thoroughly and provide practical approaches to local problems which have been identified within the group.

\section{Why ethnicized mediation?}

The term ,Roma is an umbrella term for a multitude of groups of people with similar cultural characteristics, such as language, culture and history. As such, Roma are not a homogenous section of the population but rather a plethora of communities with differing experiences, characteristics and customs. ${ }^{13}$

In Germany, Roma are a recognized national minority, and they can be distinguished by various national, linguistic, social and religious backgrounds. One can find the official differentiation between the German Sinti and Roma, who are a recognized national minority, and Roma refugees and immigrants, who have come to Germany from different countries for different reasons over the last fifty years. This differentiation is mainly based on history: The German Sinti have been in Germany since the 15th century, and it is estimated that today about 60,000 Sinti live in Germany. The German Roma, who number roughly 10,000, have been in Germany since the 19th century and immigrated mainly from Eastern Europe. ${ }^{14}$ During the 1960's, labor migrants from former Yugoslavia (mainly from Serbia, Bosnia and Macedonia) immigrated to Germany. Additionally, there are Roma refugees who have come mainly from Bosnia, Serbia-Montenegro and Kosovo since the 1990s.

This rough division already reveals the heterogeneity (motives of immigration, lifestyles, etc.) of these groups, and we can also assume a wide range of different attitudes towards what it means to be Roma. Within these four groups, there are (of course) many internal differentiations, including national origin,

13 Bundesministerium des Innern, Report, Web.

14 In the further course I use the main category Roma which includes diverse sub-groups, such as the Sinti. 
religion, social status etc., so that a Community Action Group, for example, could combine people of the second generation of immigrants from Macedonia, who are German-Macedonian Muslim Sufi together with Catholic Serbs of the first generation who have been in Germany for about 10 years now.

If we look at ethnicity as a "subjectively perceived sense of belonging, based on the belief in a common culture and ancestry ${ }^{\text {"15, }}$, we can ask how this dimension of belonging becomes relevant in the process of school mediation. Many scholars hold that "ethnic groups" (Heckmann 1992, among others) have an idea of a common origin, a sense of solidarity and a shared culture and history. A collective identity therefore is based on the awareness of the group itself, and on the judgment and attribution "from outside", from other groups ${ }^{16}$ As the mediation in this programme is by defintion based on the idea of a collective ethnic identity, negotiating membership should play a role during the mediations and/or is a reason why it takes place.

According to a study by Hristo Kyuchukov, three different possibilities for the use of Roma mediators can be identified: First, there is the so-called "Trojan Horse", a mediator who acts mainly as an instrument of the institution with the aim of reaching out to the community and having a positive influence on it. Second, the "community activists", who see themselves as representatives of the community in the fight against oppression or unequal treatment of Roma, and who therefore work more against rather than for the institution. And finally, the "real intercultural mediator", who has knowledge of the cultural codes of the community and the institution - who is impartial and focused on improving communication and cooperation between the parties. This type of mediator will encourage both sides to take responsibility and to make active changes, if needed. ${ }^{17}$

As the Roma school mediators programme aims to work with mediators from inside the community - because they can have great effects as role models and improve the outreach of the mediators programme -, it is then interesting to see how this belonging is conceptualized. Interestingly, Roma school mediation is sometimes seen as intercultural and sometimes as intracultural mediation. As intercultural

15 Wimmer, Andreas: „Ethnische Grenzziehungen: Eine prozessorientierte Mehrebenentheorie“. In: Müller, Marion/Zifonun, Dariuš (Eds.): Ethnowissen. Soziologische Beiträge zu ethnischer Differenzierung und Migration. VS Verlag: Wiesbaden 2010, p. 102 (Translation M.K.).

16 Heckmann, Friedrich: Ethnische Minderheiten, Volk und Nation. Soziologie inter-ethnischer Beziehungen. Stuttgart 1992, p. 57.

17 Kyuchukov: Roma School Mediators in Berlin, Web. 
mediation as a setting which takes place between members of different „cultures“, of different national backgrounds for example. And as intracultural mediation as a form where all parties have more or less the same cultural background. The latter implicitly works with the assumption that there must be certain commonalities belonging to one ethnic minority group. The intracultural perspective includes that this belonging is like sharing the same cultural background despite the differences of national background, religious affiliation and so forth. This idea shows parallels to the so-called "Insider Mediation", which takes place mostly in more traditional societies and where the "Insider Mediator" is usually also rooted in the ethnic, religious or cultural structures of the social context in which the conflict is rooted. ${ }^{18}$ In other words the idea is, that Roma school mediators could help to strengthen the group feeling among Roma if they are members of the ethnic minority, and not just another social worker with any migration background. Through their education, language skills and insider knowledge, they would probably convey a certain image of their group, at least when it comes to intensive exchange in conversations. Hereby, the choice of the languages within the mediation already affects the abilities to persist in a conversation, depending on whether all parties communicate in their native language or have to use learner varieties, for example. ${ }^{19}$

According to this conceptual and factual preliminary considerations the following analytical part takes a look at the ascribed roles of the mediators and positionings within real Roma school mediation processes.

\section{On (ascribed) roles of Roma school mediators}

Generally speaking mediation is often defined as a "shared conflict resolution process whereby two or more parties in dispute are assisted in their negotiation by an unbiased and objective third party “. ${ }^{20}$ But what kind of mediation do we talk

18 Berghof Foundation, CSSP - Berlin Center für Integrative Mediation (CSSP); Center for Peace Mediation (Europa-Universität Viadrina); Zentrum für Internationale Friedenseinsätze (ZIF) (Eds.):

Friedensmediation - Kurzinformation \& Vorschläge für die Politik. Berlin 2013, p. 2, retrieved 25.03.2015, from: http://www.zif-berlin.org/fileadmin/uploads/analyse/dokumente/ veroeffentlichungen/Kurzinfo_Mediation_30042013.pdf

19 Cf.: Knapp, Annelie: „Interkulturelle Kompetenz: eine sprachwissenschaftliche Perspektive“. In: Auernheimer, Georg (Ed.): Interkulturelle Kompetenz und pädagogische Professionalität. 3. Auflage. VS Verlag für Sozialwissenschaften: Wiesbaden 2010, p. 85.

20 Kruk, Edward (Ed): Mediation and conflict resolution in social work and the human services. Nelson-Hall Publishers: Chicago 1998, p. 4. 
about here? As Olivier Peyroux puts it in his article on positive discrimination and Roma school mediation: The concept of mediation used by the programme ROMED

[..] stresses three essential points which we come across again in most of the work done on the concept of mediation:

- the presence of a latent or open conflict between two parties,

- a request or an agreement by these two parties to appoint a neutral mediator,

- decisions taken which lead to changes in both camps.

Next to the, by Olivier Peyroux described, very broad simmilarities we find lots of differences in the description of the work of a Roma school mediator and therefore in the idea of mediation in this context. Stating with what mediation is originally associated, the following definition of mediation by the Council of Europe in the "Guide for Roma school mediators/assistants", indicates a shift of context as the ROMED programme seeks to establish the process of mediation in a new, unfamiliar setting.

Mediation is a process originally [accentuation M.K] associated with the resolution of conflict situations through the intervention of a neutral third party: the mediator. The mediator participates in the agreement or at the request of the parties to the conflict. The decision resolving the conflict situation is made by the parties rather than the mediator. ${ }^{21}$

As this statement - and also not in the further course of the statement - does not specify an alternative idea of mediation in this particular context, the following collected statements show how the role of the Roma school mediator is described within various contexts of the programme, from people who work for and with it. One of the coaches of the programme in Berlin summarizes the objectives of the training programme as follows:

The work of the mediators consists in promoting cooperation and communication, but mainly in initiating a change of perspective. Change of perspective on the side of the teachers is mainly anti-discrimination work [...] and on the side of the Roma, for example to open up career prospects, to show how a formal qualification, an education and the achievement of a job are well within reach. ${ }^{22}$

21 Rus, Calin; Zatreanu, Mihaela: Guide for Roma mediators/assistants. Published by the Council of Europe. 2009, retrieved 30.11.2014, from http://www.coe.int/t/dg4/education/ roma/Source/Guide_EN.PDF

22 Cf.: Expert-Interview with Christoph Leucht, Berlin 17.09.2014. (Translation M.K.) 
According to one of the initiators on the EU level, the programme's main objectives are described as follows:

We need well-trained cultural mediators to help reach out to Roma communities. We need them to inform and advise parents on the workings of the local education system, and to help ensure that children successfully make the transition between each stage of their school career. We need mediators to bridge the gaps that exist between Roma children, families and communities, and the schools and other services which are meant to serve their needs. [..] Their mission is clear and precise - to restore and enhance dialogue and trust between the Roma communities and the societies in which they live. ${ }^{23}$

She also summarizes the role of a Roma school mediator based on this example:

[..] in Romania a young Roma girl was on the point of dropping out of school because she could no longer cope with her schoolmates' bullying. Luckily, ROMED-trained mediator Elena [last name omitted, M.K.) was there for her. Elena managed to get this girl a place on an innovative programme aimed at building self-esteem. And this young girl went on to take part in the Romany Language and Literature Olympiad. She overcame others' prejudices and her own fears, and entered one of the most prestigious high schools in Bucharest. To me, this poignant example encapsulates what mediation is all about, and why it is so important. ${ }^{24}$

This last example shows very precisely that Roma school mediation refers more to a general assistance in everyday life, which can be performed in multiple ways. Emphasizing that this is a prime example of Roma school mediation, the speaker shows how little the underlying concept of the Roma school mediation has to do with the standard concept of mediation. Roma school mediators - and we can assume the existence of many other school mediators as well - more or less do the work of social workers and act not only as mediators in conflicts. These school mediations cannot be "reduced“ to classical triadic mediations. Roma school mediators provide various kinds of assistance and the work is not reduced to the setting of the school. The main and regular work is situated here, but the mediators meet pupils and their parents within their neighbourhood, visit the pupils' homes and also help with appointments in administrative offices for example.

The so called "Code of Ethics for Mediators", published in 2012 by the programme ROMED, introduces ten statements concerning the behaviour of Roma school mediators during their work and mentions the (above briefly discussed)

23 Vassiliou, Androulla: Roma Mediators - the way forward, ROMED congress, Bruxelles, 17.01.2013, P. 3 f. retrieved 12.04.2014, from http://eeas.europa.eu/delegations/council _europe/documents/press_corner/focus/20130117_discours_a_vassiliou_congres _des_mediateurs_romed_en.pdf

24 Vassiliou, Roma Mediators, p. 3 f., Web. 
heterogeneity of Roma in the form of an awareness towards diverse Roma communities with different traditions and cultures. The mediator

(1) respects the human rights and the dignity of all persons and acts with honesty and integrity in performing his/her duties; (2) works to ensure equal access to rights while respecting legal requirements and administrative procedures; (3) is responsible to help those concerned find mutually satisfactory solutions but does not have the responsibilty to provide solutions to all problems raised by beneficiaries or by the staff of the institution; (4) is proactive, has prompt reactions and develops sound prevention activities; (5) keeps confidentiality of the information obtained in the course of professional activities; (6) does not use his/her role and power to manipulate or to harm others; (7) respects the traditions and culture of the communities, provided that they are compatible with the key principles of human rights and democracy; (8) will treat all community members with equal respect and disclose publicly situations of conflict of interests; (9) makes a clear distinction between professional and private activities; (10) collaborates with other mediators and with other professionals; ${ }^{25}$

As we see, a variety of ideas is connected to the concept of mediation. By introducing the term "cultural mediators", it is stressed that the Roma school mediation programme wants to improve the relationship between the minority of the Roma and the respective so-called majority societies, and not just solve single problems between different parties. As they are meant to "bridge the gaps", it is clearly implied that there are differences between Roma and the official actors, which are usually seen as part of the majority society. The Roma school mediators are referred to as intermediators between the minority and these official actors, and not as mediators between the pupils for example. Trust and dialogue need to be built up and improved with "the societies in which they live" and do not really seem to be part of in this view. In comparison to the stated change of perspective, the adressed „cultural mediator" mainly seeks changes within the Roma community, whereas the "perspectivechanger" is not a neutral third party anymore. The Code of Ethics makes the mediator responsible for communication and understanding between the Roma communities and the respective institutions such as the schools. Insinuating that the communities may not act in accordance with the „key principles of human rights and democracy“, emphasizes the conformity with the prevailing law. At the end a lot of the semantics used within the context of the programme implicitly see the responsibilty for the marginalized situation of a lot of Roma within the Roma communities.

25 ROMED: Code of Ethics for Mediators. 2012, retrieved 30.11.2014, from http://romed. coe-romact.org/sites/default/files/code\%20ethicEN.pdf 


\section{Positionings within the Roma school mediation}

With the differentiation from Kyuchukov in mind and in order to see how ideas of ethnicity, group heterogeneity, the role of the mediator and the underlying concept of mediation are reflected in real mediation processes, we will take a brief look at some first-hand exemplary data collected within a Roma school mediation. The excerpts from the conversation between a Roma school mediator and a pupil discussed here took place at an integrated secondary school in a large German city. ${ }^{26}$ The student had just been excluded from the classroom and was instructed by the teacher to go to the social workers' room. There, the pupil meets the Roma school mediator, who invites the pupil for a talk. The two of them then have a conversation which lasts approximately one hour, sitting at a table in the social workers' room. I was introduced as the mediators' colleague, who would like to witness a mediation. ${ }^{27}$ The student is, at the time of the recording, 14 years of age, born in Germany and her parents are both from Serbia. The Roma school mediator is, at the time of the recording, in her 40s, was born in Serbia and has lived in Germany for about 15 years. Both speak Serbian and Romanes besides German, which in the case of the pupil is her mother tongue and in the case of the mediator is her third language. She started learning German when she came to Germany 15 years ago.

As the data collected so far has shown, the role of the mediator varies very much from conversation to conversation. The following first brief statement shows how and in what matter the mediator stresses her membership of the school system. The two speakers talk about a classmate of the pupil who had missed lots of classes lately. ${ }^{28}$ The mediator establishes her position as part of the school

26 Conversational situations which are recorded for my doctoral thesis and are thus considered part of the mediations are situations in which there are two or more parties with a Roma school mediator in a quasi „closed“ conversation. Situations in schoolyards, in hallways or at locations outside the school are involved, but can not be recorded, and are thus not subject to a detailed conversational analysis.

27 I sit behind the two on a sofa, but can see both speakers very well and record the conversation by audio recording. During the conversation, a social worker enters the room, who does not sit down, but is engaged in various activities and participates repeatedly in the conversation. I do not participate in the conversation, except by a few approving laughs. My presence and the fact of the entering social worker make clear that the conversation does not take place in a protected, concealed space. Accordingly, the possible consequences for the openness and lack of confidentiality for the two speakers has to be taken into consideration.

28 S1 stands for speaker 1 who is the pupil and S2, the speaker 2, for the mediator. 
system (line 06) by adressing formal rules and demanding authority. She trys to make a clue of what the pupil knows and thinks about the times of absence of the classmate. ${ }^{29}$

\begin{tabular}{|c|c|c|}
\hline 01 & S1: & $\begin{array}{l}\text { sie MEINT=sie hat immer BAuchschmerzen } \\
\text { she says she always has a belly ache }\end{array}$ \\
\hline 02 & S2: & $\begin{array}{l}\text { dre: } i \text { wochen la:ng, } \\
\text { for three weeks, }\end{array}$ \\
\hline 03 & S1: & $\begin{array}{l}j:: a \quad((\text { lacht })) \\
\text { yes ((laughs)) }\end{array}$ \\
\hline 04 & S2: & $\begin{array}{l}\text { und nich zum arzt hingehen, } \\
\text { and not going to a doctor, }\end{array}$ \\
\hline 05 & S1: & $\begin{array}{l}\text { sie meint DOCH sie geht beim arzt und so } \\
\text { she says yes she goes to a doctor }\end{array}$ \\
\hline 06 & S2: & $\begin{array}{l}\text { a:ber wir bekommen keine entschuldigung; } \\
\text { but we haven't received any doctor's excuse; }\end{array}$ \\
\hline 07 & S1: & $\begin{array}{l}\text { ich weiß nich } \\
\text { I don't know }\end{array}$ \\
\hline
\end{tabular}

The category-bound activity "Entschuldigung bekommen" (to receive a doctor's excuse) puts the mediator on one level with the teachers and the school system as only the "authorities" demand an excuse. The „we" therefore refers to the mediator as part of the school employees. It does not reflect the mediators intermediary position between the pupils and the teachers anymore. She clearly states in whose name she is speaking at the moment.

In some cases the mediator also shows clear signs of insider-knowledge and tries to establish understanding by emphasizing her role as part of the Roma community, like the following excerpt shows:

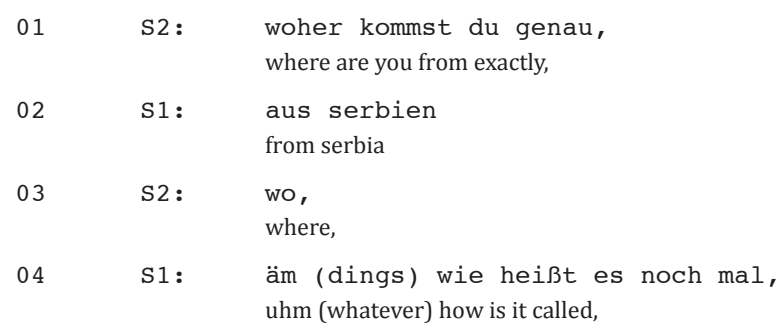

29 The recordings have been transcribed according to GAT (Gesprächsanalytisches Transkriptionssystem). Cf: http://www.gespraechsforschungQozs.de/heft2009/pxQgat2.pdf 


\begin{tabular}{|c|c|c|}
\hline 05 & S2: & $\begin{array}{l}\text { warst du nisch in dem stadt, } \\
\text { have you never been to that city, }\end{array}$ \\
\hline 06 & S1: & $\begin{array}{l}\text { DOCH: ich vergiss imma mein stadt wie die } \\
\text { heißt ((lacht)) } \\
\text { YES: but I always forget the name of my city ((laughs)) }\end{array}$ \\
\hline 07 & & $(-)$ \\
\hline 08 & S2: & $\begin{aligned}(), & <\text { Nennt einen Städtenamen }>> \\
& <<\text { States a city name }>>\end{aligned}$ \\
\hline 09 & S1: & $\begin{array}{l}\text { da } \ll \text { wiederholt den Namen der Stadt }>> \\
\text { yes }<<\text { repeats the name of the city } \gg>\end{array}$ \\
\hline 10 & S2: & $\begin{array}{l}\text { oka:y isch kenne disch ( (lacht)) (--) ABER was macht } \\
\text { deine zwei geschwister, } \\
\text { oka:y I know you ((laughs)) (--) BUT what do your two sibblings do, }\end{array}$ \\
\hline 11 & $\mathrm{~S} 1:$ & $\begin{array}{l}\text { einer geht kindergarten und der andere (grundschule/ } \\
\text { geht schule) } \\
\text { one goes to kindergarden and the other one (to elementary school/ } \\
\text { goes to school) }\end{array}$ \\
\hline
\end{tabular}

Especially interesting here is how the two speakers cooperate in order to develop the place of origin of the pupil (S1). At first the pupil marks a spatial belonging (line 02), which expresses the national affiliation (Serbia) without narrowing it down to a certain place. The question of "where" (line 03) is initially not further specified. In line 05 the speaker (S2) then makes it clear that she is asking for a city. Several phrases such as "Where are you from" (line 01), "my city" (line 06) and "I know you" (line 10) produce identification offers and ingroups. By asking further questions, the mediator directs the conversation and finally states a proposal for the possible origin of the student (line 08). Since the student accepts this proposal the spatial contextualization takes place in a cooperative joint negotiation. The question of whether the pupil has ever been to this city (line 05) opens up a realm of possibilities: Never or rarely having been in this city, does not mean that therefore the category "City of origin" or belonging to this is denied or doubted. From a liminal, undefined, state of not knowing, the two speakers work out a stable position of spatial association. The goal of negotiating appears thus in the production of a durable construction, a clear spatial demarcation and positions the mediator as an insider, as she is the one suggesting where the other one's city of origin could be.

In contrast, the following short excerpt shows how the mediator builds up an opposition and argues against the pupil (speaker 1). In this excerpt, the student is questioned by the Roma school mediator concerning her family situation. The school mediator tries to find out to what extent they talk to each other within 
the family about the school situation and in general about the well-being of the teenager.

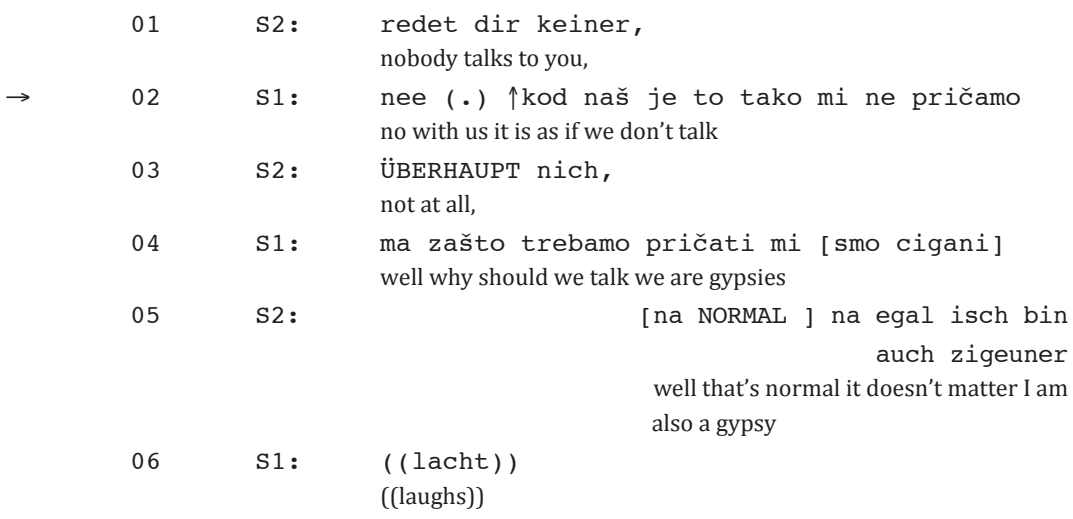

In lines 02 and 04 the pupil switches into Serbian and uses this language change for a contextualization in order to describe why they do not talk to each other a lot in her family. This assertion is expressed in the plural; it refers to a group and uses the Serbian as "we-identity" (we-code). The communicative effect which is achieved by this change is a clarification of the conversation context and production of a category-bound activity (line 04 ) stating that "Gypsies" do not talk. ${ }^{30}$ The mediator (S2) does not react to the language change and continues in German. The pupil describes the boundaries of the group as impermeable and stable (line 02 and 04 ). S2 contradicts this and declares these boundaries permeable again by saying that she too belongs to this group and that it is not the case with her. In the further course of the conversation S1 shows no attempts to restore the category "Gypsy" alongside the activity "Do not talk" again.

In summary, the variation within the positionings and the (cooperative) negotiating of membership is obvious; sometimes he or she positions him- or herself as a part of the community, as an ally, sometimes as a member of the ingroup but with different points of view, and sometimes as part of the school system as well. Already these short excerpts show that the typology of Kyuchukov can not be understood in an essentialistic way. Depending on the situation we have seen all three "types of mediators" within one conversation.

30 This is the first and only time that the word Gypsy is used during this mediation talk. 


\section{Discussion}

As we have seen, the conceptual interconnection of Roma school mediation and social work seems to ensure that the mediation in this context is also dealing with a situation of social inequality. The institutional framework is characterized by the schools, the EU-programme and the civic initiatives that employ or place the school mediators at the respective schools. ${ }^{31}$ Every single position within this system is of course highly marked by hierarchical structures, whereat the pupils are usually seen as the wards, the dependents, the teachers as the advisors and in the middle the school mediators try to establish a intermediary function.

The possible fracture of the role between the work as a mediator and as a social worker has to be taken into consideration. Are the mediators capable of working in both roles at the same time? Are these two roles at all compatible? And if so, how are they successfully applied for eachother in the everyday work of the Roma school mediators?

Maartens sees mediation as a "natural step for social workers" and ,a valuable addition to the services offered to the clients", so that mediation is added to the work of social workers and can be a service or a tool within the social work. ${ }^{32}$ „In relation to mediation, social work particularly promotes empowerment of individuals through the education of conflict resolution and communication skills, and enhances their well-being in that individuals learn new effective ways of engaging with one another during conflict. ${ }^{\text {"33 }}$

Also, the ascriptions of different roles and concepts within the same programme show a wide range of different ideas towards the role of a mediator who is ascribed to a certain group and as a "cultural mediator" has to mediate between a minority and a majority society. It is therefore a matter of emprirical studies to ask whether the institutions responsible for this programme, emphasize ethnic boundaries by focusing on ethnicity as the relevant difference marker. Is, as in the case of Roma school mediation, the ethnic dimension really that relevant to the negotiations in the school context? Or are perhaps (also) national categories, linguistic boundaries, status affiliations, etc. related to the (perceived) difficulties between teachers and pupils? The (as yet not really institutionalized) programme itself operates an ethnic boundary that is, recorded and repeated by the actors

31 Wimmer, p. 101.

32 Maartens, Elize: Mediating adolescent-caregiver Conflict: Guidelines for Social Workers. Stellenbosch: Universität Stellenbosch, unpublished master's thesis 2007, p. 58, retrieved 10.11.2014, from http://hdl.handle.net/10019.1/2216.

33 Maartens, Mediating adolescent-caregiver Conflict, p. 5. 
who work with and for it. Against this institutionalized perspective would speak if the ethnic boundaries are drawn within the mediation, and therefore maintained within interactions in the form of dialogic encounters. ${ }^{34}$ In the course of the indicated research project, further investigation based upon these remarks will be needed.

In any case, a structured evaluation and monitoring of the real necessity for Roma school mediation at German schools would help to break the wide-spread narrative that Roma per se are in need of help. While the sensitization of teachers and school management, which leads to the introduction of the programme at the respective schools, points out that there are certain problems at these schools, it would help to strengthen the position of the mediators and may be weaken "sceptical" votes if these difficulties were structured and founded in facts.

All in all we can say that the ethnicization of school mediation, as it exists in the programme discussed here, proposes to minimize discrepancies and produce greater equality between the mediator and Roma pupils by training members of the Roma minority. But, since Roma school mediators of course not only care for the Roma pupils at their schools, but in their everyday work, they also intervene in situations where non-Roma are included. They do not only mediate between Roma and non-Roma, but generally between all parties in a conflict, Roma school mediation as an ethnicized mediation, also constructs cultural differences and at least two homogenic groups. Its meant to overcome social boundaries by empowering members of the community but it also emphasizes difference and implies homogenization.

\section{Literature}

Berghof Foundation, CSSP - Berlin Center für Integrative Mediation (CSSP); Center for Peace Mediation (Europa-Universität Viadrina); Zentrum für Internationale Friedenseinsätze (ZIF) (Eds.): Friedensmediation - Kurzinformation \& Vorschläge für die Politik. Berlin 2013, retrieved 25.03.2015, from http:// www.zif-berlin.org/fileadmin/uploads/analyse/dokumente/veroeffentlichungen/ Kurzinfo_Mediation_30042013.pdf

Bundesministerium des Innern (Ed.): Report from the Federal Republic of Germany to the European Commission. An EU Framework for National Roma Integration Strategies up to 2020 - Integrated packages of measures to promote the integration and participation of Sinti and Roma in Germany. 2011, retrieved 12.04.2014, from http://ec.europa.eu/justice/discrimination/files/roma_germany_strategy_en.pdf 
Dittman, Jörg: „Zur Evaluation von Mediationsprojekten an Schulen“ In: Simsa, Christiane/ Schubarth, Wilfried (Ed.): Konfiktmanagement an Schulen - Möglichkeiten und Grenzen der Schulmediation. Deutsches Institut für Internationale Pädagogische Forschung: Frankfurt am Main 2001, pp. 63-75.

Heckmann, Friedrich: Ethnische Minderheiten, Volk und Nation. Soziologie interethnischer Beziehungen. Stuttgart 1992.

Knapp, Annelie: „Interkulturelle Kompetenz: eine sprachwissenschaftliche Perspektive“. In: Auernheimer, Georg (Ed.): Interkulturelle Kompetenz und pädagogische Professionalität. 3. Auflage. VS Verlag für Sozialwissenschaften: Wiesbaden 2010, pp. 81-97.

Kruk, Edward (Ed): Mediation and conflict resolution in social work and the human services. Nelson-Hall Publishers: Chicago 1998.

Kyuchukov, Hristo: Roma school mediators in Berlin. Commissioned by the RAA Berlin, Sponsored by the Freudenberg Foundation. 2011, retrieved 12.04.2014, from http://www.raa-berlin.de/Neu2011/PDFDatein/Kyuchukov, \%20Roma\%20School\%20Mediation\%20evaluation\%20report.pdf

Maartens, Elize: Mediating adolescent-caregiver Conflict: Guidlines for Social Workers. Stellenbosch: Universität Stellenbosch, Unveröffentlichte Masterarbeit 2007, retrieved 10.11.2014, from http://hdl.handle.net/10019.1/2216

Müller, Marion/Zifonun, Dariuš (Eds.): Ethnowissen. Soziologische Beiträge zu ethnischer Differenzierung und Migration. VS Verlag: Wiesbaden 2010.

Peyroux, Olivier: The question of Roma mediators and positive discrimination. 2011, retrieved 30.11.2014, from http://srap-project.eu/files/2011/07/Articlesur-la-m\%C3\%A9diation-Olivier-Peyroux-VF-EN-relu-par-Agir.pdf

Schmitt, Anna/Bytyci, Hamze/Heine, Wolfgang: The Berlin mobile contact point for EU migrant workers and Roma from the perspective of the service providers. EUROCITIES report. 2011, retrieved 12.04.2014, from http://nws.eurocities. eu/MediaShell/media/EUROCITIES\%20report\%20-\%20Contact\%20point\%20 for\%20Roma\%20in\%20Berlin.pdf

Simsa, Christiane/Schubarth, Wilfried (Ed.): Konfiktmanagement an Schulen Möglichkeiten und Grenzen der Schulmediation, Deutsches Institut für Internationale Pädagogische Forschung: Frankfurt am Main 2001.

Strauß, Daniel (Ed.): Studie zur aktuellen Bildungssituation deutscher Sinti und Roma. Dokumentation und Forschungsbericht. 2011. retrieved 12.04.2014, from http://www.stiftung-evz.de/fileadmin/user_upload/EVZ_Uploads/ Publikationen/Studien/2011_Marburg-strauss_studie_sinti_bildung.pdf

ROMED: About Romed, 2014, retrieved 30.11.2014, from http://romed.coeromact.org/ 
ROMED: Code of Ethics for Mediators. 2012, retrieved 30.11.2014, from http:// romed.coe-romact.org/sites/default/files/code\%20ethicEN.pdf

Rus, Calin/Zatreanu, Mihaela: Guide for Roma School Mediators/Assitants, 2006, European Code of Ethics for mediators. retrieved 12.04.2014, from http://www. coe.int/t/dg4/education/roma/Source/Guide_EN.PDF

Vassiliou, Androulla: Roma Mediators - the way forward, ROMED congress, Bruxelles, 17.01.2013, retrieved 12.04.2014, from http://eeas.europa.eu/delegations/ council_europe/documents/press_corner/focus/20130117_discours_a_vassiliou _congres_des_mediateurs_romed_en.pdf

Wimmer, Andreas: „Ethnische Grenzziehungen: Eine prozessorientierte Mehrebenentheorie“. In: Müller, Marion/Zifonun, Dariuš (Eds.): Ethnowissen. Soziologische Beiträge zu ethnischer Differenzierung und Migration. VS Verlag: Wiesbaden 2010, pp. 99-152. 


\author{
Sascha Wölck \\ (Frankfurt/Oder) \\ and Christina Rogers
}

(Dresden)

\title{
Labeling difference - On discrimination and the social standing of children fathered by US soldiers during the Vietnam War
}

\begin{abstract}
Während des acht Jahre andauernden amerikanischen Vietnamkrieges kämpften in Vietnam rund drei Millionen US-amerikanische Soldaten. 1975 endete der Krieg mit der ersten militärischen Niederlage in der Geschichte der USA. Bereits zwei Jahre vor der Befreiung von Saigon, waren die US-amerikanischen Truppen aus Vietnam abgezogen. Was blieb, war der Krieg und die Folgen einer beispiellosen Zerstörung eines Landes. Geblieben sind auch Zehntausende von Kindern vietnamesischer Frauen und amerikanischer Männer, die aus Beziehungen, Sexarbeit, Romanzen und Vergewaltigungen hervorgingen. In der Wahrnehmung großer Teile der Gesellschaft repräsentierten diese jungen Menschen Verstöße gegen einen Komplex unterschiedlicher sozialer Normen.

Die Diskriminierung nahm unterschiedliche Ausformungen an, wobei rassistische Ausgrenzung dominierte.

Mit diesem Aufsatz skizzieren wir Dynamiken politischer sowie sozialer Systeme in Vietnam und ihre Interdependenzen zu den gesellschaftlichen Positionierungen dieser Gruppe. Als Ausgangspunkt dient ein Korpus von leitfadengestützten Interviews mit 29 Betroffenen, die in Vietnam zwischen 2012 und 2014 realisiert wurden.
\end{abstract}

Schlagworte: Vietnam Krieg, Diskriminierung, Markierung, Intersektionalität

Keywords: Vietnam War, Discrimination, Labeling, Intersectionality, Otherness

\section{Introduction}

Danh $^{1}$ has started a new job. He works at a parking lot in front of an English school in Ho Chi Minh City and looks after scooters. To get the job, he dyed his rather blond hair black as a precaution, because his hair color is naturally lighter than that of the majority of people in Vietnam. The dyeing of Danh's hair was a tactical move to avoid being recognized as `con lai Mỹ - a term used to mark children of

1 All names of interview partners have been changed in this article to ensure the anonymity of informants. 
US soldiers and Vietnamese mothers in Vietnam. Danh never met his biological father Joseph, or Joe, who was an American nurse stationed at the 85th Evacuation Hospital in Quy Nhơn between 1969 and 1971. No other group of people within Vietnamese society had a connection to the USA so visibly marked on the surface of their bodies as the con lai Mỹ, tens of thousands of children who were born as a result of relationships, prostitution, romances and rape with or by Americans. From the perspective of a large portion of society, con lai Mỹ represented offences against social norms. ${ }^{2}$ Their social exclusion, at least in its extreme form, began after the withdrawal of American troops in 1973 and the Fall of Saigon in 1975. After 30 years of war, which was a time of fundamental social and political change, social roles and images of the enemy redefined themselves anew - especially in the south of Vietnam. The sex industry was regarded as an indicator of the unsuitable behavior of women during the war, but especially stigmatized after it had ended. Poverty and the absence of (biological) fathers were regarded as a stigma, and racial discrimination evolved in different forms. Relationships across ethnic or racial boundaries were seen as a breach in the normative social structure, whereby children fathered by Black ${ }^{3}$ men were more likely to be racially discriminated against than children of White fathers. ${ }^{4}$

In this article, we wish to give a brief introduction to the different social settings and acts of discrimination against children fathered by US soldiers from the war era until today. A series of interviews conducted with con lai Mỹ between 2012 and 2014 in Vietnam form the basis of the paper. ${ }^{5}$ The overall goal of this investigation is, on the one hand, to archive perspectives of this group of people on their life, as well as their social and political surroundings; and, on the other hand, to determine historical contexts that could have led to the specific social standing of con lai Mỹ until the present day.

When Danh was interviewed in 2012, he did not speak about a current fear of discrimination, although one can assume that he was somewhat insecure about

2 Cp. Yarborough, Trin: Surviving Twice: Amerasian Children of the Vietnam War. Potomac Books Inc.: Washington 2005.

3 In this text, we will use the words Black and White with capital letters to distinguish the terms from naturalizing, racial categories and to mark them as constructed, yet socially significant markings.

4 Cp. McKelvey, Robert S.: The Dust of Life. America's Children Abandoned in Vietnam. University of Washington Press: Seattle, London 1999, p. 23-27.

5 Research underlying this text is based on a series of interviews led in Đà Nẵng and Ho Chi Minh City between 2012 and 2014 by Sascha Wölck. The sample consists of 28 con lai Mỹ: 18 women and 10 men; 10 marked as Black, 18 as White; born between 1965 and 1974. 
openly showing that he is con lai Mỹ, given that he hid his natural hair color. Many other people that were interviewed since 2012 in Đà Nẵng and Ho Chi Minh City also speak of experiences of discrimination, although the data shows that many prejudices that were prevalent in Vietnamese society after the war have lost their power considerably.

To understand the social positioning of con lai Mỹ throughout history, it is important to grasp the impacts a label such as con lai Mỹ has had on this specific collective. To highlight this form of labeling, it is necessary to describe the political, economic and social structures surrounding the group of people in question. What are the conditions by which people are marked as con lai Mỹ, and what does this name entail? What are the structures that create and reproduce these forms of exclusion that are linked to the label? Are negative attributions a result of war trauma, political enemies, ethnic and racial prejudices, or rather a question of gender and class? In the following section, we will give a brief introduction into the problems raised by the name >con lai Mỹ from a scholarly perspective, and thereby deliver attributions that people affected by the name face in their daily lives. We will then describe different forms of discrimination and structures that could have led to the specific social standings of con lai Mỹ throughout history, and highlight the categories gender, class, ethnicity and/or race as dominant modes of representation and exclusion.

\section{The intricacies of naming}

A basic translation of >con lai Mỹ < is >Child Mix Americar. It is a term that points to the different origins of both parents, where the alleged US birth parent is stressed by the word $>$ Mỹ $\triangleleft$. The adjective $>$ Mỹ $\triangleleft$ is particularly interesting, because it points to the >Otherness $<$ of the child, that part of the person which indicates that the person was not born from a relationship between two people who are defined as being >Vietnamese . As we shall see in the second section, the indicators for being Vietnamese do not necessarily mean citizenship. A child born from a Việt Kiêu $u^{6}$, or better Người Việt Hải Ngoại ${ }^{7}$, with US citizenship and a Vietnamese citizen does not trigger the labeling >con lai Mỹ ; rather, they are either identified through a US American parent (documents, known relationships etc.) or through racial and ethnic profiling, which leads to the usage of the name. The term does not clearly mark the historical collective of people born during the Vietnam War, because all

6 Việt Kiều is a term used to refer to Vietnamese people living outside of Vietnam.

7 Người Việt Hải Ngoại is the preferred term within the Overseas Vietnamese community. 
people who were born in Vietnam before, during and after the war who have an American and a Vietnamese parent are included in the expression.

The most common name within academic texts on children born by US soldiers in Vietnam is $>$ Amerasians ${ }^{8}$. The notable quality of this imposed term is that it is practically non-existent as an expression in Vietnam, and therefore does not have an internal history within the socio-political sphere. To be precise, the positive quality of the term >Amerasians $<$ is that it does not have a discriminatory connotation within the context of Vietnam, and can be used as a fairly neutral term within local communication. For the same reason, the term `Amerasians does not belong to any form of self-labeling of our interviewees. From the perspective of con lai Mỹ who went to the USA, and especially for anglophone academic texts, the term >Amerasians has a certain validity. Although the term was initially introduced by US immigration offices to describe children with an Asian mother and a US military father, today a community does actually define itself with this term within the USA. Thus, >Amerasians` currently includes all people who have an American and Asian parent, although in popular use the term is also employed to describe US citizens with Asian ancestry, and can therefore be used as a pejorative and essentializing label. In Trin Yarborough's book Surviving Twice - Amerasian children of the Vietnam War', the term is well-suited for analysis, as she traces biographies which lead from Vietnam to the USA. In the context of this paper, the adoption of the term is unsatisfactory for three reasons: First, >Amerasians ‘ is unknown to the majority of our interview partners, and can therefore not be considered as suitable for further research in this specific field. Second, the selectivity of the term is relatively small. >Amerasians is a term that can be used for large groups of people in and outside of the USA, and therefore does not refer to the particular experiences and circumstances of the con lai Mỹ in Vietnam as compared to similar and/ or different stories in the Philippines, Japan or other countries. Third, the term is inevitably positioned within a discourse of so-called `America's children «. Western academic literature, political and public dialogues have often used $>$ Amerasians $<$ in relation to themes about America's alleged >lost children ‘ in Vietnam. Considering the American hegemonic history in Vietnam, as well as discourses leading to misrepresentations of Vietnam that legitimized many adoptions, the term cannot be implemented without problematic or even offensive connotations.

8 Cp. DeBonis, 1995; Yarborough, Trin: Surviving Twice: Amerasian Children of the Vietnam War. Potomac Books Inc.: Washington 2005.

9 Ibid. 
In her book The Life We Were Given - Operation Babylift, International Adoption and the Children of War in Vietnam, ${ }^{10}$ Dana Sachs avoids any commitment to a distinct term and uses both >Amerasians as well as >con lai<. >Con lai implies a >non-Vietnamese parent $\triangleleft$ for the people involved. While `con lai and also >con lai Mỹ` were indeed regarded as discriminatory titles in the post-war era, ${ }^{11}$ the names are perceived today as neutral labels according to interviewees. When asked about her opinion on the theoretical problem of terms and definitions, the interview partner Hà recommended the use of >con lai<. Against her advice, we decided not to use >con lai< as a concept to work with. Similar to >Amerasian`, >con lai is an undifferentiated term. The omitting of the adjectival $>$ Mỹ` (America/USA) here allows a distinction between con lai Mỹ and other historical groupings that are important to Vietnam's history, such as offspring of Japanese (`con lai Nhật ‘) and French (`con lai Pháp $<$ soldiers. Although one can find similarities between the social positioning of >con lai Pháp in comparison to con lai Mỹ after the Vietnam War, >con lai` as a stand-alone term does not entail the specific social, economic and political situations of people with foreign military fathers in Vietnam in this particular historical time frame. Speaking about con lai Mỹ who were born during US military presence in Vietnam therefore specifically encompasses the historical conditions during and immediately after the war, as well as the experiences of the massive changes in their social positioning while growing up in the 1980's and 1990's - a time of profound economic and social changes due to Vietnam's economic opening Đổi mới.

In its literal meaning, >con lai Mỹ bundles many of the key problems people who were fathered by US soldiers face in Vietnam: they are constantly thrown back to their point of alleged >origin « - their status as a child resulting from a Vietnamese mother and an American father. What the term thereby stresses are the circumstances of their birth and nothing of the life that followed thereafter. The fact that most con lai Mỹ who stayed in Vietnam have no or only poor knowledge of the English language, were educated in Vietnamese schools, grew up within a Vietnamese society and its politics, have a Vietnamese mother or more often a whole Vietnamese family which adopted them, is usually unacknowledged. >Con lai Mỹ therefore delivers a terminology with which people can possibly be essentialized as an own distinct subjectivity signified as >Child Mix America<, wherein the `Other` within the `mix` plays a dominant role. Thus, the term itself points to the discrimination and segregation that interviewees experienced in their lives.

10 Sachs, Dana: The Life We Were Given: Operation Babylift. International Adoption, and the Children of War in Vietnam. Beacon Press: Boston 2010.

11 Cp. DeBonis, 1995 , p. 5. 
So why then use the term as a scholar in the field? Two reasons indicate con lai Mỹ as being a useful term: in the course of the research, it became more and more apparent that people within the chosen field had taken on the term as a positive label of self-definition, leading to the creation of a community under the name con lai Mỹ. Not only could we find a slow but constant tendency to release the term from its pejorative and possible discriminatory impact within mainstream society, most importantly it showed that the term delivered a structure under which many people could establish solidarity networks. It is therefore noteworthy that the name con lai Mỹ has been, and is still, undergoing constant shifts in meaning, a process in which the people immediately affected by it are very engaged. This point brings us to the second reason why con lai Mỹ seems a well-suited conceptual term for the analysis of this group of people: it is a multifaceted term. Keeping con lai Mỹ as a conceptual term incorporates the self-designations of interview partners, and at the same time conveys its possible derogative meaning within Vietnamese society. So, as an analytic category, the term neither functions as a seamless cover, nor does it reproduce an entirely repressive or hurtful labeling. We consider the ambiguity of the term as strengthening the analysis, because the social realities of con lai Mỹ are no less ambiguous.

\section{Creating difference - Family, Gender and Ethnicity}

Othering mechanisms that dissociate the con lai Mỹ individually and collectively from Vietnam - and also link them to the USA - appear as dominating topics in the interviews that form the basis of this text. They are influential as tools for social exclusion and discrimination, as well as the self-identification of many interview partners. Interviewee Dũng states: »My classmates always asked me why I do not go back to my home country [the USA, ]. I replied: if I go back or not is not your problem. ${ }^{12}$ The most obvious issue of these attributions is that con lai Mỹ not only have American fathers, but also Vietnamese mothers, and it would seem no less natural to identify con lai Mỹ as Vietnamese instead of American. Whatever definition one might have of cultural identity, the interview partners are surely closer to a Vietnamese cultural identity than an American one. Only one of the interview partners speaks English, for example. The question is, therefore, which

12 Dũng, interviewed by Sascha Wölck, 2012. There are also many cases, in which the linkage to the USA is an important personal reference point. Hoàng states: »The only thing I am proud of are my people. The people of my father. I dream of being in the military, like my father. If I could have stayed with my father, I would have done the same job as him in the US military.« Hoàng, interviewed by Sascha Wölck, 2012 
factors are effective in building the basis of these misrecognitions that seem to be more dominant than socio-cultural upbringing, and that hinder the identification of con lai Mỹ via their life in Vietnam or their Vietnamese mothers.

One possible approach can be made from a linguistic-cultural perspective of the family and gender: within the Confucian social structure, one can differentiate between an sinner family< and an >outer family<. The paternal branch is the sinner family«, and the maternal branch is the `outer family«. The system of the inner and outer family reads as follows:

- ông nội >Interior - Grandfather ( father of father) as well as `ba nội - Interior Grandmother (mother of father).

As well as

- >ông ngoại > External - Grandfather (father of mother) as well as `ba ngoại - Exterior - Grandmother (mother of mother).

This patrilineal kinship system could be a possible explanation for the precarious positioning con lai Mỹ had within many families: In all cases, the biological fathers - the sinterior-lines - were absent. ${ }^{13}$ Interview partner Dũng refers to himself according to this structure and explains: "It is like this: I am only a >ngoại child, not a `nội c child. That is not what I am. ${ }^{14}$ It is likely that in some cases con lai Mỹ symbolized the sexual activities of women outside of the family or traumatic experiences via practices of sexual violence and domination by US soldiers that affected and even threatened the family constellation. Despite these perspectives, women and the maternal line were indeed always `ngoai $<$ - exterior, according to the Confucian understanding. One cannot claim that Confucianism is the only socially structuring and relevant belief system in Vietnam. Buddhism and Christianity play important roles (and sects that oscillate between them, like Cao Đài). Especially within the $20^{\text {th }}$ century, secular ideologies, prominently communism, were strong and demanded equality for women. However, communist politics of the family have taken a constant contradictory position concerning gender roles. At an early stage, communists in Vietnam strengthened the position of women: in 1930, equality of genders was established in the party program, and the state guaranteed men and women the same institutional rights in the constitu-

13 It must be noted, that there is one form of exception: The stepfather of Tính refused to acknowledge that Tính is a con lai Mỹ and not his biological son. By treating him as his biological son and demanding from every other person to see him as such, the stepfather created an interior-line of the family for Tính and himself.

14 Nghi, interviewed by Sascha Wölck, 2012. 
tion of 1945. At the same time, one can trace a hesitation to question classic gender roles within the family. For decades, the `Gia đình văn hóa` (English >Culture Family<), which has social-conservative and Confucian traditions at its core, was proclaimed as an ideal by communist government propaganda.

This heterogeneous picture is also reflected within the sample. It not only entails biographies in which the con lai Mỹ were disadvantaged and excluded, but it also predominantly shows cases in which massive problems emerge. The biography of Nhung in Đà Nã̃ng is an example of a low and isolated position within the hierarchy of the family: Her mother found a new partner and he brought children of his own into the marriage. Nhung, as the daughter of the mother, was the one who was not granted any position within the constellation of the family, while the man's children became integral members of the new family. Nhung states:

My mother got married. Other children existed in this family. This is why it was said I should live with my grandfather. He [the husband] had an own family and his wife died in the war and the man already had children. This is why he gave me to the grandfather. My mother brought me to the grandfather. I stayed there until I was grown up. ${ }^{15}$

According to Nhung's understanding of the situation, violence from her relatives was connected to the absence of her biological father:

Sascha: Why did people hit you?

Nhung: First, because I was a child without a father. Second, because I didn't have a mother. Third, I was with my grandparents and therefore couldn't go to school. ${ }^{16}$

Hưng, Nhung's husband, commented on the problems with Nhung's family in an interview as follows: »It was bad because she came from another blood line. This brings harm to the family. ${ }^{17}$ The reference to the bloodline can be understood as the dominating line of the inner family, in which fathers of individuals seem to define the ethnic and racial categories. In addition, the terms ^blood and $>$ race are often used synonymously in Vietnamese language. The question of >wrong blood c could be an answer to why the family of Hai, the child of a Black French soldier and interview partner, left him in Vietnam, while other children in the family were taken abroad with them. This example also shows that Nhung should not be regarded as a singular or unique case.

When wanting to grasp the discrimination against con lai Mỹ in their daily lives, it is therefore crucial to take ethnic or racial categorizations into account as

15 Nhung, interviewed by Sascha Wölck, 2014.

16 Ibid.

17 Hưng, interviewed by Sascha Wölck, 2014. 
well as gender issues. As our arguments shall suggest, many of the con lai Mỹ that grew up in a family without their biological fathers were regarded as incomplete according to the Confucian tradition of the family. This conservative ideal of the family put more pressure on women, who had experiences as sex-workers during the time of war, and also led to discrimination against con lai Mỹ due to alleged sexual wrongdoings by their mothers. Dũng states: "Back then, as today: people talk bad about families with con lai children. They say: > You are con lai - fuck you. They look at your mother and think she is a prostitute. ${ }^{118}{ }^{18}$ Kien Nguyen describes the case of his mother, who was forced to speak to a public crowd in 1975: A confession of her wrongdoings against the Communist Party, the new government and the social corpus was expected of her, because her $"$ mixed-blood children ${ }^{19}{ }^{19}$ were regarded as indicators for prostitution. She being forced to humiliate herself performatively via a speech-act in front of a small public crowd shows the precarious social status of former female sex workers and mothers of con lai Mỹ in post-war society. ${ }^{20}$ As one can also see in this example, it is not only a marker or a label like con lai Mỹ which entails segregation from normative society via the term $>$ Child Mix Americar, but also the usage of speech in the public sphere which plays a crucial role in understanding repressive forms of language within society. Kien's mother was forced to tell the public what they already knew or at least assumed of her in an act of self-accusation and self-shaming. The indicators for her alleged unsuitable behavior were thereby her children, which were marked as ethnically different. Other cases show similar mechanisms. Con lai Mỹ were blamed for the sexual actions of their mothers, and vice versa, the mothers were socially confronted for having con lai Mỹ as children. Visual appearance and the question of ethnicity raised by public readings of people show that often simple racial profiling led to the labeling of children as con lai Mỹ, whereby lighter or darker skin color and hair were regarded as indicators of their (and their mother's) difference.

Although the >culture family< is not specifically described as ethnically >Vietnamese‘, one can find numerous traces of racial discrimination against con lai Mỹ. An indicator for a more severe form of discrimination against children of Black

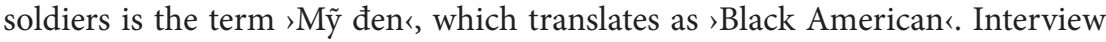
partners and theoretical texts often distinguish between offspring of White and Black fathers, because children experienced different forms of discrimination according to their outer appearance. None of the interview partners spoke of >con

18 Dũng, interviewed by Sascha Wölck 2012.

19 Cp. Nguyen, 2001, p. 111.

20 Ibid. 
lai Mỹ đen` (Black con lai Mỹ) or >con lai Mỹ trắng` (White con lai Mỹ). Instead, shorter forms like `Mỹ đen` or `Mỹ trắng « were common. `Mỹ đen « was cited by informants to describe situations in which they experienced discrimination. As a locution, it was therefore strictly used as a form of negative appellation from the outside world. With this shorter form `Mỹ đen`, people addressed were stripped from their hybridity, from an identification via their mother, their place of birth, or their upbringing. Interview partner Hương states:

They shouted at me I should go away. A stone shot with a sling, with which one usually hunts birds, hit me on the head. Yet, as I became older, the discrimination stopped. As a young person, I was constantly exposed to such situations; I was again and again discriminated. [...] Mỹ trắng could go about undisturbed. But when they saw Mỹ đen, they threw stones at them. [...] Mỹ trắng never had problems. With white skin, one looked like everyone else. [...] When I went to school, they waited for me behind the gates and shouted: >Mỹ đen, go back to where you came from! $\stackrel{21}{ }^{21}$

As the quote shows, the pupils of Hương's school approached her with racist views, in which Black skin and curled hair are read as markers of negative difference, as that which cannot be Vietnamese. With respect to interviews conducted with children of White fathers, we do not want to go as far as Hương and claim that they had no problems of their own. As Danh at the beginning of the text shows, even lighter hair color or other markers of Whiteness were regarded as negative traits within Vietnamese society. What is often true, though, is that White con lai Mỹ could pass as Vietnamese far easier than children of Black soldiers. Among 18 White interviewees, three were not aware of being con lai Mỹ until they were told by relatives when they were teenagers. However, all twelve Black con lai Mỹ were marked as Black and con lai Mỹ since childhood. As extensive interviews in the field show, ethnic or racial discrimination, as well as discrimination as children `without biological fathers`, are the strongest and most frequent forms of exclusion con lai Mỹ have faced in their lives. However, it must be noted that this form of discrimination was predominantly a matter of the public sphere. As the family was often a space of private exclusion for many con lai Mỹ, the sample does not deliver indicators that people of darker color were more strongly affected by discrimination within the family than White con lai Mỹ. It can be said with certainty, though, that racial profiling was a paramount factor for discriminatory actions against con lai Mỹ in public areas, such as schools or work places. Even the nicknames of some of the interviewees still end with `đen` (black), which never occurs with `trắng` (white).

21 Hương, interviewed by Sascha Wölck, 2012. 
Gastambide assesses the precarious social positioning of con lai Mỹ, and concludes that they were imagined as an own race within Vietnamese society:

They are outcasts of the Vietnamese society [...]. We are part of the gruesome history of Vietnam. The War gave birth to us and now we are the absolute losers. We became a race within the Vietnamese race, created by the American presence in Vietnam. ${ }^{22}$

In a similar conclusion, interview partner Hương summarized her experiences of discrimination with the sentence: "They mobbed me, because another blood flows within me ${ }^{23}$. Another typical rhetoric of the time is delivered with Nhat's sentence: »They said I should go back to America - I had curly hair « ${ }^{24}$.

An analysis of our data in the field shows that assumed communist vocabulary was hardly used against children of US soldiers throughout the 1980s. In rare cases during the first years after the war, con lai Mỹ and their mothers were labeled political traitors or imperialists. Such vocabulary completely vanishes from the scene in the 1980's, showing a clear and early focus on ethnic categories and labels concerning the family. The marker con lai Mỹ, as already highlighted in the first section, reduces people to an alleged ethnically mixed race. The part of themselves that could be considered $>$ Vietnamese is mostly forgotten or simply overwritten by that which is seen as different. As the terms `Mỹ đen` and `Mỹ trắng`show more specifically, people are blatantly reduced to their physical appearance and discriminated against for their alleged ethnic difference to mainstream society. What can be excluded from all of the statements about con lai Mỹ is a reaction to them as unquestionably deviant from society. Stuart Hall describes this mechanism precisely:

Here, racism is particularly powerful and its imprint on popular consciousness especially deep, because in such racial characteristics as color, ethnic origin, geographical position, etc., racism discovers what other ideologies have to construct: an apparently "natural" or universal basis in nature itself. ${ }^{25}$

Also, as a scholar with a background outside of Vietnamese society, one must be constantly aware of this seemingly universal basis which has a naturalizing effect via the attributions of members of the field. Yarborough's Surviving Twice is one of

22 Translated by authors; Gastambide, Remy: „Staub des Lebens. Die schwarzen ,Amerasians' von Vietnam“. In: Haus der Kulturen der Welt (Hrsg.): Gap Viet Nam. Selbstverlag: Berlin 1999, p. 102.

23 Hương, interviewed by Sascha Wölck, 2012.

24 Nhat, interviewed by Sascha Wölck, 2012.

25 Hall, Stuart: "Race, Articulation, and Societies Structured in Dominance." In: Baker, Huston A. Jr.; Diawara, Manthia; Lindeborg, Ruth H. (Ed.): Black British Cultural Studies: A Reader. University of Chicago Press: Chicago, London 1996, p. 56. 
the best academic publications on con lai Mỹ, and delivers the most extensive and detailed existing study utilizing this mostly disregarded academic perspective on the Vietnam War. Unfortunately, Yarborough's choice of words in describing the physical appearances of con lai Mỹ, as well as her analytic evaluations, demonstrate a tendency to exotisize her interview partners, thereby reproducing colonial stereotypes and images of the Other. Even on the first pages of Yarborough's book, the description of the skin colors of her interviewees sounds like an assortment of colonial goods: »coffeecolored $\aleph^{26}$, »chocolate-colored $\aleph^{27}$ and $»$ cocoa-colored $\aleph^{28}$. In her further analysis, she emphasizes that >Amerasians often have an unsettled personality, and tend to have sexual relationships with both genders ${ }^{29}$ seemingly suggesting that their ethnic and cultural hybridity is, or leads to, a natural biological state that can cause forms of sexual desire and mental conditions functioning in a similar duality.

As these examples show, when describing people and their lives as a scholar, there is often a fine line between wanting to live up to their experiences of difference and refraining from turning this difference into a reproduction of naturalizing and racist views common within societies, as well as social sciences. This is especially the case in field work, where many interview partners quite correctly describe themselves as different from society, and support this position by, for example, pointing to their physiological markings. To stress Stuart Hall once more:

The ways in which black people, black experiences, were positioned and subjected in the dominant regimes of representation were the effects of a critical exercise of cultural power and normalisation. Not only, in Said's 'Orientalist' sense, were we constructed as different and other within the categories of knowledge of the West by those regimes. They had the power to make us see and experience ourselves as 'Other'. ${ }^{30}$

\section{The impact of political and economic development}

After Roosevelt's insinuated promise of national independence fell short, and Vietnam was not granted independence from France after the Second World War, ${ }^{31}$ the formulation of a cultural difference to former and future hegemonic

26 Yarborough, 2005, p. 4.

27 Ibid, p. 8.

28 Ibid, p. 9.

29 Ibid, p. 2, 24, 207.

30 Hall, Stuart: "Cultural Identity and Diaspora." In: Rutherford, Jonathan (Ed.): Identity: Community, Culture and Difference. Lawrence and Wishart: London 1990, p. 225.

31 Cp. Maxner, Stephen: Vietnam und USA. In: Bundeszentrale für Politische Bildung (Hrsg.): APuZ Politik und Zeitgeschichte 27/2008. Sozietäts-Verlag: Berlin 2008, 
powers became more relevant. This encompassed a collective national identity as the ideological basis and connecting element of a liberating nationalism, first against France and then later against the USA. The rhetoric of the Việt Minh and their subsequent organization constructed $>$ being Vietnamese $<$ in very vague terms as a negative image defined against past and present occupying forces within the

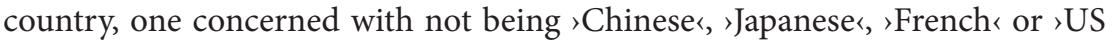
American . With the consolidation of governmental power across the whole country at the end of the Vietnam War, it seems like the Communist Party changed their rhetoric concerning the newly joined citizens of Vietnam. As we briefly mentioned earlier in the text, accusations focusing on being a child of an enemy, or >Traitors to the People‘, hardly appear in our sample. After the enforcement of the primary goal of reunification, the constitution of Vietnamese nationalism via the identification of internal and especially external political enemies had lost its force within society. From the perspective of our interviewees, political rhetoric after 1975 plays a less important role in affecting discrimination against them than other factors. Even though con lai Mỹ are still faced with prejudices, one can trace clear shifts in their social standing from the mid 1980's until today. Two factors played a crucial role in this change within society, and interestingly enough they are both economic.

In 1985, a journalist from Newsweek took notice of homeless and begging con lai Mỹ in the metropolis Ho Chi Minh City. His portrayals of their living conditions, which were quickly linked to a public dialogue on sour children in Vietnam <, caused a wave of public empathy in the USA and initiated the active engagement of American charitable associations in Vietnam. Following a campaign by a group of high school students, the US government decided to implement the Amerasian Homecoming Act (AHA) in 1987, and the foundation of an Amerasian Transit-Centre in Ho Chi Minh City in 1990. According to numbers from the American consulate, 21,379 con lai Mỹ emigrated to the USA between 1988 and $2013 .{ }^{32}$ The implementation of these acts marked a considerable change in the social conditions of con lai Mỹ. Formerly associated with poverty as well as social and ethnic transgressions, con lai Mỹ were suddenly regarded as valuable people who received tickets to the USA, a place that inevitably was linked to images of wealth and the possibility for a better life. This perception was magnified during the devastating economic situation in Vietnam after 1975, in which many

p. 25-32; Frey, Marc: Geschichte des Vietnamkriegs. Die Tragödie in Asien und das Ende des amerikanischen Traums. C.H. Beck: München 2004, p. 17.

32 Cp. http://travel.state.gov/content/dam/visas/Statistics/AnnualReports/FY2013Annual Report/FY13AnnualReport-TableX.pdf (23.03.2014). 
citizens were struggling to overcome the negative impact of 30 years of constant warfare. Con lai Mỹ suddenly received attention from a broad surrounding, most importantly by persons who were willing to adopt them or to fake family relations to them in order to apply for immigration to the USA. Hung, the husband of interview partner Nhung, stated in an interview: "I was very poor and the money wasn't enough. I had the idea, that if I married her, she would go to the USA and take me with her or send me money « ${ }^{33}$. Due to this widespread misuse of the act, where alleged relatives of Amerasians tried to immigrate to the USA, the AHA was soon discredited and suspended at a preliminary stage. Of course, this sudden shift in attention and decrease in discrimination did not emerge for humanitarian reasons. Rather, con lai Mỹ had received a useful value from the American government for people willing to immigrate to the USA. As such, con lai Mỹ were again objectified; this time, not as abject or alien subjects within a 'healthy Vietnamese society, but as tickets to the West. It is hardly surprising that some of the contacts con lai Mỹ had to people before the AHA had come to a halt thereafter; however, many of the informants still speak of a change and decline in social exclusionism after this phase of economic recognition. Ngọc states: »As the plan to bring con lai Mỹ from Vietnam to the USA emerged, we were not discriminated anymore ${ }^{34}$.

The most extensive changes in social standing took place in the 1990s, when the economic reforms Đổi mới initiated in 1986 started to have an effect on the economic lives of Vietnamese citizens. On a political level, Đổi mới not only marked an economic opening to the West, but can also be regarded as an opening with regard to Western culture. Whereas formerly the leading dictum was a cultural shielding from ideals and topics from the imperialist West, Đổi mới initiated the steps that led to the import not only of Western goods, but also of many cultural aspects, such as sports, music, food, consumer culture, valuation of status symbols, etc.. The general political discourses then started to focus on reconstructing the country by changing Vietnam's devastated economic condition since the end of the war, stressing a common future under better circumstances instead of searching for internal enemies to denounce or blame for the past. On a smaller level, the general increase in wealth, creation of jobs and increased access to health care for the citizens of Vietnam created a less tense and offensive climate for con lai Mỹ. Even though the phase of economic recognition towards con lai Mỹ put in place by the AHA and other programs described above was a fleeting

33 Nhung \& Hủng, interviewed by Sascha Wölck, 2014.

34 Ngọc, interviewed by Sascha Wölck, 2012. 
improvement, one can definitely trace a sustainable change in attitude towards con lai Mỹ in this time of economic growth. Two primary factors led to this considerable improvement in the environment surrounding the con lai Mỹ: First, the perception of the USA transformed from imperialist enemy to economic ally, and even began to represent a desirable way of living on a socio-political scale. Second, a general decrease of frustration within the private sphere in the form of better financial positioning among the general population. Finally, one can see that the class position of con lai Mỹ themselves also played a crucial role in easing social tensions. Of course, racial discrimination and transgressions against gender or family normativity were not solved by this economic wealth, yet it must be noted that many of the interviewees could use their improved class position as a form of capital to counter different forms of prejudices. Many interview partners state that once they managed to integrate into the social fabric via steady jobs or a family of their own, their stigmatization became less prevalent. ${ }^{35}$

A lot of interviews in the field therefore show that forms of social exclusion functioned intersectionally. Trường notes: »Because I was poor and didn't have a father, they shouted >Mỹ đen ‘ at me « ${ }^{36}$. Trường's attempt to explain reasons for his discrimination is exemplary for how intertwined categories of social positioning are. In this sentence, there is a mixture of class, family status and race that lie at the core of his interpretation of social exclusion. In this field of research, it is therefore important to acknowledge the intersectional and multilayered mechanisms that underlie many of con lai Mỹ’s experiences.

\section{Conclusions}

In this paper, we have shown that the historical collective of people pooled under the label >con lai Mỹ، have faced different forms of discrimination in their daily lives. The term >con lai Mỹ، itself delivers insight into key components of social and cultural exclusion, as the term >Child Mix America $<$ was used as a negative marker pointing to the Otherness of a person in the years directly following the Vietnam War. The rehabilitation of the term as positive self-labeling, as well as a constant decline in discrimination against the con lai Mỹ, might indicate that Vietnamese society increased its level of tolerance towards children of American

35 While most of the Black con lai Mỹ interviewees still sense a certain degree of depreciation, most of the White con lai Mỹ do not feel discriminated anymore. Some of the latter, in contrast, show a certain pride of their visual features, like their skin color, a smaller nose or blonde hair.

36 Trường, interviewed by Sascha Wölck, 2012. 
soldiers within the last decades. However, as the last chapter shows, it is problematic to view their social improvements definitively as such, because a variety of external factors changed the social prestige of the con lai Mỹ. This development, therefore, does not necessarily indicate a change in social concepts within Vietnamese society. As we have argued, crucial turning points took place in the 1990s - the time of the AHA and Đổi Mới. With the AHA, con lai Mỹ were suddenly associated with a chance to go to the USA, and therefore with the prospect of prosperity. Đổi Mới, on the other hand, made it possible for at least some of the interviewees to escape poverty (to a certain degree), and along with that discrimination as members of a lower class. Moreover, large proportions of the con lai Mỹ emigrated to the USA with the AHA; thus, the large and publicly visible group of con lai Mỹ widely vanished from Vietnam as a whole. From this perspective, one can also argue that the historical collective of con lai Mỹ structurally changed, thereby affecting the social standing of people that stayed in Vietnam.

One of the unexpected findings of this research is that discrimination against con lai Mỹ within the family is a very important aspect to consider when trying to grasp experiences con lai Mỹ have had on a daily basis. The Confucian belief system, in which children are distinguished between `nội - interior and `ngoại $<-$ exterior, shows how our interview partners were linked to their absent fathers within their family (and henceforth socially) instead of to their mothers. One can also trace a linkage between racist views and the dominance of the paternal mindset when appearances such as the color of skin are used to mark con lai Mỹ as ıngoaii within the public sphere. Interviews show that ethnicity and race are dominating categories when speaking of discrimination in Vietnam. Especially Black con lai Mỹ have faced discrimination, while children of White American soldiers could more easily pass as >Vietnamese`, and are thus far less often the target of social prejudices in public areas. An interesting outlook for this research could be an investigation of Vietnam's experiences of racism and White hegemony under French and US dominance, and incorporations of such colonial ideas into Confucian concepts of the family and kinship in Vietnam. Until further research in the field can shed light on such pending questions, an interim result of the data is that - counter to widespread assumption - con lai Mỹ and their mothers are seldom confronted with accusations that label them as political traitors, imperialists or children of the enemy. Rather, intersecting categories linked to race, family, gender relations and class status lie at the core of discriminatory practices against con lai Mỹ. 


\section{References}

DeBonis, Steven: Children of the Enemy. Oral Histories of Vietnamese Amerasians and Their Mothers. McFarland: London 1995.

Frey, Marc: Geschichte des Vietnamkriegs. Die Tragödie in Asien und das Ende des amerikanischen Traums. C.H. Beck: München 2004.

Gastambide, Remy: "Staub des Lebens Die schwarzen ,Amerasians" von Vietnam". In: Haus der Kulturen der Welt (ed.): Gap Viet Nam. Selbstverlag: Berlin 1999, pp. 102-103.

Großheim, Martin: "Erinnerungsdebatten in Vietnam". In: Bundeszentrale für Politische Bildung (ed.): APuZ Politik und Zeitgeschichte 27/2008. SozietätsVerlag: Berlin 2008, pp. 19-25.

Hà, Kien Nghi: Vietnam Revisited. Demokratisierung, nationale Identität und adoleszente Arbeitsmigration. Wissenschaftlicher Verlag Berlin: Berlin 2005.

Hall, Stuart: "Cultural Identity and Diaspora." In: Rutherford, Jonathan (ed.): Identity: Community, Culture and Difference. Lawrence and Wishart: London 1990, pp. 222-237.

Hall, Stuart: "Race, Articulation, and Societies Structured in Dominance." In: Baker, Huston A. Jr.; Diawara, Manthia; Lindeborg, Ruth H. (eds.): Black British Cultural Studies: A Reader. University of Chicago Press: Chicago, London 1996, pp. 16-61.

Maxner, Stephen: "Vietnam und USA." In: Bundeszentrale für Politische Bildung (ed.): APuZ Politik und Zeitgeschichte 27/2008. Sozietäts-Verlag: Berlin 2008, pp. 25-32.

McKelvey, Robert S.: The Dust of Life - America's Children Abandoned in Vietnam. University of Washington Press: Seattle, London 1999.

Neale, Jonathan: A People's History of the Vietnam War. The New Press: New York, London 2001.

Nguyễn, Kien: The Unwanted - A Memoir of Childhood. Back Bay Books: New York, Boston, London 2001.

Sachs, Dana: The Life We Were Given: Operation Babylift. International Adoption, and the Children of War in Vietnam. Beacon Press: Boston 2010.

SarDesai, D.R.: Vietnam - The Struggle for National Identity. Westview Press: San Francisco, Los Angeles 1992.

Yarborough, Trin: Surviving Twice: Amerasian Children of the Vietnam War. Potomac Books Inc.: Washington 2005. 

Harald Weydt

(Frankfurt/Oder)

\title{
Linguistic borders - language conflicts. Pleading for recognition of their reality.
}

\begin{abstract}
Schon bei oberflächlicher Betrachtung zeigt sich, dass Sprachgrenzen und Konfliktlinien in engem Zusammenhang stehen und weitgehend zusammenfallen. Wir möchten das Konfliktpotenzial, das Sprachunterschieden innewohnt, als eine unausweichlich auftretende Gefahr charakterisieren, die quasi automatisch aus dem Sprachgegensatz entsteht, als eine vorfindliche Realität. Damit stehen wir im Gegensatz zu Interpretationen, die Sprachkonflikte als unverständlich auffassen, allenfalls als künstlich von oben oder außen geschürt. Zwei solcher Sichtweisen werden kurz angesprochen: der marxistische Ansatz und eine jüngere Variante; letztere reduziert Sprachgrenzen und die sich daraus ergebenden Folgen auf rein mentale Konstruktionen, die typischerweise von Eliten instrumentalisiert werden. Gegenüber solchen Auffassungen behaupten wir, dass Sprachkonflikte als reale Fakten anerkannt und ernst genommen werden müssen. Erst wenn man die Natur von Sprachunterschieden versteht, wenn man den Prozess erkennt, in dem Konflikte entstehen, und wenn man sich vor Augen führt, wie sie die Harmonie zusammenlebender Gruppen bedrohen, erst dann kann man Wege finden, das Konfliktrisiko zu minimieren und sogar die Vorteile sprachlicher Vielfalt zum Wohl der Gemeinschaft entfalten
\end{abstract}

Schlagworte: Sprachkonflikte verstehen- Konfliktpotential - sprachliche Vielfalt - Sprachkontakt

Keywords: Linguistic diversity - conflict potential - understanding language conflicts language contact

\section{1. (Mis)Understanding language conflicts}

In the course of my life, I have experienced many ethnic and linguistic conflicts. It was particularly in the time when I taught in Montréal at the French-speaking Université de Montréal from 1969 to 1971 that I could see up close the arguments and actions of the people of Québec. These occasionally violent events prepared me for perceiving conflicts; in the ensuing time period, I was able to see linguistic tensions, hostilities and political dissents where other people - above all people from outside and especially people from monolingual states - would not have seen them. I saw that the world was far from being linguistically peaceful. I am personally most influenced by the situations I experienced in the province of Québec, Kazakhstan, (Kirgizstan, Tadzhikistan), Belgium and Catalonia. In addition, my 
perception was sharpened because I found very often myself in a minority situation, where all the people around me spoke their mother tongue and did not care much about me. There, I was exposed to the situation that a minority non-native speaker undergoes every day: I experienced how easily you can be overlooked, and how difficult it is to be taken seriously as an equal partner.

In the areas with ethnic/linguistic conflicts, I took great interest in understanding what happened. Most of the time I had friends on both sides of the conflicts; at the very least, I found people who explained their points of view to me. One concomitant question that I never let out of my mind was how one could mitigate or solve these conflicts. Another question I asked myself and the people involved was how and why these tensions and conflicts between the groups had arisen. I must underline that I came to know my discussion partners on both sides as people who were personally peaceful, just, and considerate. I further admit that in most of the cases, I could perfectly understand both sides and would have been able to defend and to explain their cases to others. This impression stands in blatant contrast to the bitterness of the linguistic conflicts in which they were involved. The contradiction between the amiable and peaceful character of these people and their intransigent behavior gives rise to a widespread astonishment, and is probably one of the sources of misunderstanding. Brubaker and many sociolinguists conclude that these people (speaking mostly of members of minorities such as Hungarians in Romania, in the days of Russians of the Crimea and in the Ukraine) are seduced, incited, exploited, and misled by leaders. "Here, as elsewhere, the protagonists of the conflict have been organizations, not groups.” (Brubaker 2002, p. 179).

\section{Groups}

Ethnic groups are a subset of groups. Groups can have other foundations than ethnicity. There are even groups that come into existence without showing particular features - except that their members belong to the same group.

Groups without characteristics

Sherif s experiments: As early as in the late 40 s and early 50s of the last century, Muzafer Sherif, professor at Oklahoma State University who had immigrated from Turkey, conducted his famous "summer camp experiments".

$1^{\text {st }}$ Phase: Boys were split into two equal different camps, contrary to existing friendships.

$2^{\text {nd }}$ phase: They developed a very narrow intensive consciousness of a we-group. 
$3^{\text {rd }}$ phase: They developed a consciousness of superiority towards the other group, they liked competition against the other group, and there were even acts of group specific aggressiveness.

$4^{\text {th }}$ phase: both groups could be reconciled if they saw:

- a common enemy,

- common needs (like lack of water),

- shared advantages,

- friends they had in common.

This example shows prototypically the origin of groups and of group conflicts. Note that these groups were composed of members who had nothing in common with what is normally attributed to a group: they had not known each other before, had no common history that could be invoked, nor did they share common economic interests, values nor any beliefs that would incite opposition toward the other group. New conflicts came into being almost automatically; no leaders incited them.

School classes:

The next example of this category are classes of high school students belonging to the same class. Most German readers might know such groups, who, many decades after their Abitur ${ }^{1}$, still gather in celebration of its anniversary. In other countries, "homecoming events" are also very popular. Again, the respective class members don't share any characteristics beyond belonging to the same school class. In most of these classes, one can find great internal differences in parents' wealth, predilection for certain subjects (mathematics, sports, literature), there are good students and those who are not quite so good, and they have diverse political opinions. It is interesting to see that such groups establish their own distinct identities. Teachers confirm that they like class A, find class B boring, class $\mathrm{C}$ interesting and so on. The groups persist, often for their entire lifetimes.

These two examples underline that, in order to come into being, to persist, and to compete with others, groups need neither leaders nor commonly shared features that oppose them to other groups.

\section{Language Conflicts}

But this is not to say that all group borders are arbitrary and insignificant. There are indeed defining borders based on features that are very important for the groups and for their survival.

1 Abitur: Graduation examination at grammar school required for entry into higher education. 
In contrast to the aforementioned holiday camps, school classes and "alumni cohorts" stand linguistic groups, the members of which speak different languages. Linguistic borders are among the most consequential ones, as their members do have a decisive feature in common (namely the usage of a common language) that distinguishes them from other groups.

\section{1. The inferiority of the non-native Speaker}

In this discussion, I concentrate on the most frequent type of linguistic conflicts: Two languages, $A$ and $B$, are spoken in the same region; most speakers of language A are monolinguals, though some may have limited proficiency in B; on the other hand, almost all speakers of $B$ are bilinguals. As a consequence, the speakers of $A$ are privileged in two respects (see 3.1.1 and 3.1.2).

\subsubsection{Profession and public life.}

As it is extremely difficult and rare that people maintain their mother language at a satisfying level while simultaneously developing a high level of language proficiency in another language, the non-native B speakers will be less perfect in A, though they have to invest much more time and energy into learning it. Their imperfect proficiency will hinder them decisively in many respects, of which only some selected examples will be given.

- B speakers do worse in job interviews,

- they need much more time to write ambitious texts, including proposal writing (and they still need editors),

- they will be less convincing on the telephone or in business conferences.

- They will read more slowly and with a lesser degree of quick and exact understanding.

- The same holds for their oral understanding, above all when there is background noise or when the discourse is dialectally influenced.

\subsubsection{Discourse structures.}

Much more subtle are the disadvantages that B speakers have to face on the conversational level. To enumerate only some of the ordinary non-native's handicaps, he/she:

- faces word-finding problems, i.e. he as more difficulties than his partners in finding adequate expressions and grammatical constructions for what he wants to say, 
- must - besides thinking of the content of his speech - permanently control and monitor his correctness in grammar, idiomaticity, and vocabulary, an effort that absorbs a great part of his intellectual potential.

- The non-native speaker, struggling with the foreign language, is aware of his own deficiencies; he recognizes his partner's superior command of the language, which weakens him in defending his own position.

- In the turn-taking game, he gets fewer turns. As he speaks slowly and hesitates while searching for his words, the others tend to interrupt him easily.

- He is much less fluent and eloquent.

- He can do little to work on his own face or on that of his partner - or at least considerably less than the native speaker.

- His turns are not linked to the preceding ones, so that his counterparts assume that their content has been accepted, as they were not contradicted.

- Contradiction, if necessary, requires great effort and the speaker has to be prepared for a certain amount of conflict.

- Very often, B speakers will have to suffer from the native speakers' patronizing attitudes, for example when they help them when they search for words, or when they correct their oral utterances.

- His competence in establishing compromises is very limited, i. e. in establishing them and following through with them. He has to work with a sledgehammer instead of a scalpel, so to speak. -

- In short: for B speakers, it is more difficult to contradict the preceding turn without struggle.

Here, I would like to introduce a striking example of the non-native speakers' inferiority. It stems from an experience at an international congress which took place in Lyon (France) in 1994, a sociologists' and social workers' congress, with the title "Quartiers en danger", "Endangered neighborhoods", organized by the European Community. There were two admitted conference languages, French and English, and there were simultaneous translations from each of these languages into the other. The first day of the conference and the morning of the second one was devoted to working groups. Each working group determined one person for the task of reporting the results to the plenary session. The participants were more than happy that they could pass this job to the native speakers ${ }^{2}$. On the second day, a Plenary Session was held where speakers of each working group presented

2 There was one exception, a German woman. I saw her writing her report word-forword, while all the others enjoyed their leisure time. 
their results and discussed them with the audience. I kept record of the discussion in just noting

- the country that the speaker represented,

- the language used (French or English),

- the lengths of the contributions in minutes and seconds.

For example: 3) F, f, 2:35 would mean: 'Third speaker, French native speaker, French language, two minutes and 35 seconds'. The discussion went as follows:

1) I (Irish) e $3: 15$; - 2) F f 2:50, - 3) P (Portuguese) e 0:15; - 4) E e 4:16 (relaxed, eloquent and humorous); - 5) G (Greek) e 0:10; - It f 0:34; and so on, and so on. ${ }^{3}$

It costs the non-native speakers quite some will power to rise to speak. The audience did not give much attention to their stammered contributions.

Anyone can observe that similar events happen very often in international public debates, and she/he will realize that the native speakers have much longer turns; their utterances are more convincing, wittier, and it is more fun to listen to them.

As the reports they made emphasized their own view, the natives controlled the plenary session much more than the non-francophone or the non-anglophone Europeans.

It goes without saying that the picture would have been completely different if the congress' languages had been, say, Italian and Danish. The Italian and the Danish participants would have dominated the congress; they would have shown great expertise in the subject and would have been admired by everybody for their rhetorical excellence and the humorous and brilliant way of presenting their experiences and ideas. They would have used the floor to expose their ideas. The native speakers of French and English would have been sitting silently in the audience, eaten up by inferiority complexes and would have been unable to contribute to the opinion-forming, let alone to control it.

The constellation of two people who decide on the common language is comparable to that of two friends who decide to go in for sports together; one is, physically and genetically, a marathon runner, the other one is more of a weightlifter. Whoever of these two agrees to take part in the other's sport, is doomed to be forever in an inferior position.

3 As I don't have my notes of the conference any longer, which was held 20 years ago, I have invented a prototype of this discussion. It could be reproduced under similar conditions. 


\subsection{Why and how language conflicts emerge}

As people with two high-level mother tongues are extremely rare, the prevailing group holds the so called "definition power" (Esser 1996, p. $80 \mathrm{ff}$.); the speakers of B face - and they recognize it very clearly and rationally - immense losses in what everybody aspires to: physical well-being, material goods and social esteem. Esser (1996) proposes a gradation of conflicts: On his 6-point scale, the sharpest conflict is the zero-sum conflict, where whatever is won by one party is won at the expense of the other. Language conflicts are such null sum conflicts. „The winner takes it all“ (Mamma mia).

This iniquity is the source and the origin of most, if not all, language conflicts. B speakers perceive their inequality as unjust because they feel that they have to carry the full burden of learning, maintaining, and further developing an additional language, and they know that instead of gaining a reward, they are penalized for their extra effort. -

Not always will this unequal distribution of rights lead to the outburst of an open conflict. Before the B speakers will revolt against their situation, at least two more conditions ( $\mathrm{a}$ and $\mathrm{b}$ ) have to be fulfilled. They must consider the situation a) unjust and b) changeable.

A schema, modified from Giles/Bourhis/Taylor's well-known article on group behavior (1977, table 3, p. 332), shows a cluster of four cells (A - D).

Figure 1: Feelings of the B-group towards the fairness and the changeability of the situation (modified from Giles/Bourhis/Taylor 1977)

\begin{tabular}{|l|c|c|}
\hline & $\begin{array}{c}\text { felt as justified } \\
\text { ("legitimate) }\end{array}$ & $\begin{array}{c}\text { felt as unjust } \\
\text { ("non legitimate") }\end{array}$ \\
\hline $\begin{array}{l}\text { Changeable ("cognitive alternatives } \\
\text { perceived") }\end{array}$ & $\begin{array}{c}\mathbf{1} \\
\text { (unstable, ?) }\end{array}$ & $\begin{array}{c}\mathbf{2} \\
\text { outburst of conflict possible }\end{array}$ \\
\hline $\begin{array}{l}\text { Unchangeable } \\
\text { ("no cognitive alternatives perceived") }\end{array}$ & $\begin{array}{c}\mathbf{3} \\
\text { accepted, stable }\end{array}$ & $\begin{array}{c}\mathbf{4} \\
\text { unstable }\end{array}$ \\
\hline
\end{tabular}

Cell 1: This case is somewhat problematic and not very common. We may think of indigenous populations who adopt the former colonists' language.

Cell 2: This is the field where conflicts burst out. Good examples are the Baltic nations after acquiring independence. They had always felt that the Russians imposed their language and way of life upon them, and considered this as very unjust. When they acquired their independence, they reintroduced their respective languages in their countries as privileged means of communication. The same 
holds for Kazakhstan, Uzbekistan, Kyrgyzstan, and Tadzhikistan, as I have personally observed, but also in Georgia.

Ukraine: The most recent example of a global crisis caused to a large extent by language conflict is the situation in Ukraine. February $2^{\text {nd }} 2014$, two days after the pro-Russian president, Viktor Yanukovych, had tried to flee from Ukraine as a consequence of the "Maidan Revolution" (or "Euromaidan"), and days before the parliament elected a new president (Jazenjuk), the Parliament decided to repeal the language law of 2012 (Law "On the principles of the state language policy"). This law guaranteed the Russian language an official status, together with Ukrainian. As a consequence of this amendment, Russian would lose its status as co-official language. Although this amendment was immediately vetoed by the acting president of Ukraine, Oleksandr Turchynov, it caused an uproar among the ethnic Russian population, and especially in the Eastern parts of the Ukraine, including the Crimea. This factor contributed to the outbreak of a political crisis". On June $29^{\text {th }}, 2014$, however, the new president, Petro Poroshenko, reversed the repeal, declaring that "The only official language of Ukraine was, is, and will be the Ukrainian language" (German Press Agentur (dpa) from: Der Tagesspiegel, Berlin, June $30^{\text {th }}, 2014^{5}$ ), a statement that will make it very difficult for the Russian population of Ukraine to accept peace conditions. The linguistic aspect of the conflict seems to me to be underestimated in foreign politics and in the media.

Belgium is another relevant example. Both of Belgium's main linguistic regions, Wallonia and Flanders, consider the other side's demand to abstain from using their own language for intra-national communication as very unfair. Since the beginning of the $20^{\text {th }}$ Century, the country has undergone major alterations: the state, culturally and economically dominated by speakers of Walloon (French), developed into a country whose majority speaks Flemish and has become economically dominant, while the capital, Brussels, has become francized. The linguistic tensions between the two regions make the country almost ungovernable. Belgium has been without a government for quite some time. The Flemings insist on equal rights for both languages, and as the Walloons refuse to speak Flemish, the Flemings decline to use French. If a third language has to be used, English, the Flemish are privileged because of the linguistic similarities between English and Flemish.

4 Comment of The Christian Science Monitor (Febr. 28, 2014): “The [adoption of this bill] only served to infuriate Russian-speaking regions, [who] saw the move as more evidence that the antigovernment protests in Kiev that toppled Yanukovich's government were intent on pressing for a nationalistic agenda."

5 This story occurred on the day I wrote this. 
Another example seems to be the situation in Romania described by Brubaker (2002), namely the Hungarian-speaking minority, Cluj-based and organized in the DAHR (Democratic Association of Hungarians of Romania) in conflict with the Romanian nationalist parties. Brubaker interprets this conflict as being instigated by elites (especially the Romanian nationalistic mayor of Cluj Funar on one side and the Democratic Association of Hungarians of Romania on the Hungarian side) and their organizations. Whether this is an unprejudiced interpretation is doubtful. It could be influenced by an idealistic a priori conviction that there is primarily interethnic harmony which is disturbed from above. Contemporary witnesses of the Romanian situation tell a different story. The German singer Peter Maffay was raised in Borsov (Kronstadt, Romania). The following excerpt from his biography is illustrative:

„Ab dem 10. Lebensjahr, um 1959, nahmen die Prügeleien zu, radikalisierten sich die Einstellungen: rumänische Jugendliche gegen deutsche Jugendliche, deutsche Jugendliche gegen ungarische Jugendliche und andersrum. Jeder gegen jeden, und eigentlich wusste niemand genau warum überhaupt. Oder doch! Da die Eltern unter dem System litten, erschien es den Kindern wie ein Akt stillschweigender Solidarität, auf der Straße ebenfalls unmissverständlich ihre Meinung zu sagen - egal, in welcher Sprache. Messerstechereien waren bald an der Tagesordnung, insbesondere, wenn Ungarn beteiligt waren. Auch wenn zunächst nur bedroht wurde, gab es in späteren Jahren häufig Verletzte. Wenn der Musiker Maffay bis in die Gegenwart stets ein Klappmesser in der Hosentasche bei sich trägt, stammte diese Angewohnheit aus jener Zeit. ${ }^{\text {“6 }}$ (Harsch/Maffay 2009, p. 25)

This is definitely not a conflict evoked by authorities. - Cell 2 contains cases such as the aforementioned French-speaking Quebecois and the other Frenchspeaking minorities in other provinces of Canada. In Spain, only after Franco's death language rights were openly claimed, as - in the Catalans' understanding the moment for change and for claiming their rights and even independence had come. One could cite as further examples the languages of former Yugoslavia, for example the separation of the mainly Albanian-speaking Kosovo.

6 From his 10th year onwards, the fighting increased and the attitudes became more radical: Romanian youngsters against German youngsters, German youngsters against Hungarian youngsters, and vice versa. Everybody against everybody, and nobody really knew exactly why at all. Or did they? As the parents suffered under the system, for the children it was an act of tacit solidarity to unambiguously assert their opinion in the streets, in whatever language. Stabbing became quite frequent, in particular when Hungarians were involved. While at the beginning there were mostly threats, in later years injuries occurred frequently. The fact that, up to now, the musician Maffay always carries a switchblade in his pocket stems from that time (own translation, H. W.). 
Cell 3: The cases that belong in Cell 3 are quite unproblematic. B speakers migrating into a monolingual state, for example Europeans who nowadays emigrate to the United States. They know in advance that the language of their new country is English and that they have to learn it. There is nothing they can do about it, they agree with it and they do not perceive it as unfair.

Cell 4 represents the numerous cases where the non-native speakers don't think that the situation can be changed. This was the case for Kazakhstan at the time of the Soviet Union. As many Kazakhs resigned and accepted their fate as inevitable, Kazakhstan became the most russified non-Russian Republic of the Soviet Union, an attitude which changed after the decline of the Soviet Empire. The Kazakhs moved toward cell 2 .

This systematization is still too schematic; to be accurate, the values should be represented as continua rather than binary dichotomies.

More adequate would be this presentation:

Figure 2

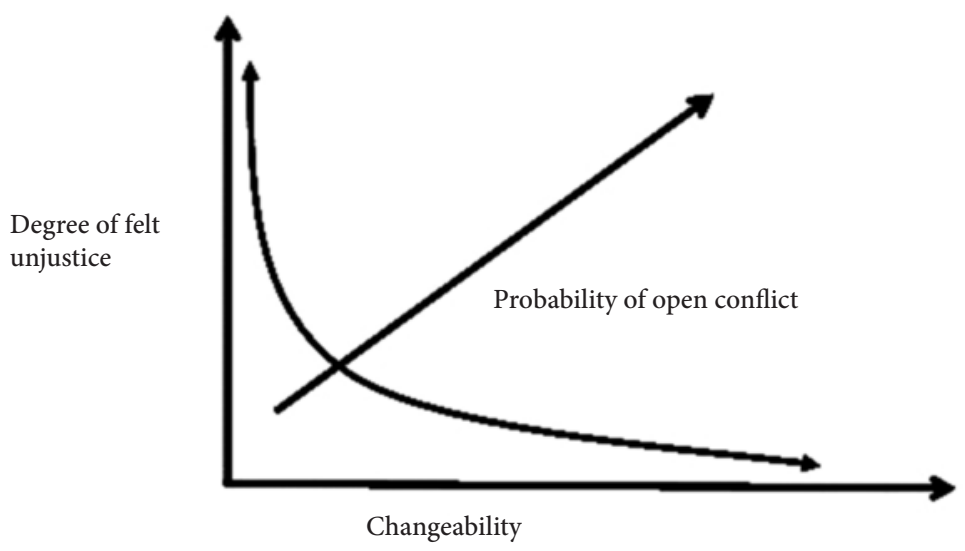

Figure 2 takes into account the gradual character of the parameters: in the view of the people involved, a situation can be more or less just, and the chance of bringing about a change can be higher or lower.

Linguistic conflicts can be sharpened. This happens regularly when linguistic borders coincide with other borders - with lines that separate religions or with lines that divide economic classes. One example is the Province of Québec, where traditionally the speakers of French are Catholics and relatively poor, less educated and traditional, while English speaking Protestants or Jewish Anglophones are much wealthier, more educated and more progressively-minded. In Belgium, the 
economic situation has been reversed: in recent decades, the economic power has shifted from Wallonia to Flanders, a change which is difficult for the Walloons to accept.

\subsection{Explanations we don't believe in}

A short look at explanations we don't believe in:

The history of linguistic thinking offers three typical and influential examples.

First: the myth of the building of the tower of Babel. A wrathful God sent humanity the curse of diglossia as a punishment for their haughtiness. This suspicion towards the coexistence of several languages was - at least in part - revoked in the event of Pentecost, where God conferred upon future missionaries the ability to speak foreign languages.

Second: The Marxist tradition contains the idea that multilingualism is an impediment to progress. Pure Marxist ideology considers history a process of vertical conflicts, the driving force being the struggle of the classes, a conflict from bottom to top and vice versa. Logically, vertical lines that separate nations, languages, cultures, and religions are all negligible; whoever takes them seriously into consideration in politics is somewhat backward and reactionary ${ }^{7}$, this in spite of the fact that the Soviet Union was, in its self-concept, a multicultural and multiethnic state (Rom-Sourkowa 2004). In the former Soviet Union, I met old people who would still tell you that it was very dangerous if documents written in the Arabic language were found in their house.

In both examples (Babel and Marxism), the idea of natural harmony in monolingual societies is central; disturbance of this harmony is seen as a fall of mankind, a punishment or as an unfair and reactionary act.

In monolingual societies, the animosity against serious coexistence of languages is widespread. There is a chorus of outrage like: "How is it possible that in our century there are still these chauvinist people who don't want to speak the common language and who make a lot of fuss about their language", together with the self-praise of being very tolerant like: "We do not want to prevent them from speaking their language. Let them speak what they want at home, but when speaking with us, they should be understandable".

7 Remember that Max Weber (1922) predicted that the evolution of modern societies would entail a weakening of ethnic communities and so contribute to dissipate ethnic conflicts, an unfulfilled prophecy. See Popova (in print). 
On the side of monolingualism are peace, harmony and progress; on the side of diglossia are guilt, disturbance and culprits.

Third: In line with these conceptions there is a mainstream of modern sociolinguistic approaches. One representative is Brubaker; he describes language conflicts as initiated by elites, by persuaders, by chauvinist culprits. Adherents take for granted that conflicts are caused by troublemakers, and do not even consider the idea that linguistic conflicts emerge from a highly unfair distribution of rights and chances, and that they can be mitigated.

\section{How can linguistic conflicts be avoided?}

As coexistence of languages tends to lead to tensions, one must try (to speak in Esser's 1996 terms) to convert the resulting zero-sum conflicts into lower level conflicts. One must try to distribute the costs of language differences to both sides.

An important first step, maybe the most important one, is to wake up the A speakers' awareness of the immense costs the B speakers encounter in interlingual communication. In other words: it is necessary to convince the A speakers of the costs that B speakers face if they use language A in their common conversation. I have often observed a complete lack of awareness of the imposition, for example in the Anglophone community in Québec, in the Francophone community in Belgium, in Russophone communities in the former Soviet republics, among Spaniards in Catalonia and in the Basque provinces. The A speakers argue:

- it is so much easier to communicate in A as everybody speaks it,

- speakers of A have - most unfortunately - less talent for foreign languages and are therefore unable to learn $\mathrm{B}$,

- in contrast to A, language B is so complicated that it is practically impossible to learn,

- the practical value of B is so limited that the discrepancy of costs and achievement forbids one to learn it,

- besides: nobody forbids speaking B. At home and in private surroundings, everybody is free to speak it: "Let them speak what they want".

- The costs of bilingualism are too high.

There can't be a solution as long as there is no awareness. As a general rule: To tone down the conflict, compromises must be agreed upon.

There is a wide range:

- Bilingualism as a precondition for eligible positions as a good incentive (see South Tirol), 
- acquisition of the other language as an important school subject,

- high weight of language proficiency in the other language in high school graduation exams,

- equal recognition of certificates in both languages,

- creation and maintenance of public and private esteem for the minority language,

- above all: cultural and social recognition of bilingualism,

- establishment of regions of different linguistic dominance.

One can also refer to the fact that learning the less prestigious language brings advantages which are often not thought of. Walloons who learn Flemish will have considerable advantages when acquiring the more important Germanic languages English and German (and in general other foreign languages); learning French, the Canadian Anglophones gain access not only to the Francophone areas in Europe and overseas, but also to the gigantic Spanish-speaking and Portuguesespeaking territories because of the common lexical, morphological and syntactic features of the Romance languages.

\section{Prospects}

It should be in the interest of all parties involved to prevent linguistic conflicts and to avoid their negative consequences. However - apart from calculating the political necessity - there is an ethical aspect that should not be concealed. Learning, speaking and using a foreign language is much more than a rational decision intended to assure maximum political profit. Those who use languages that are not their mother tongues open their views, leave their narrow perspective behind, they demonstrate respect and solidarity for others, for the variety of cultures and ways of expression. They receive a double reward.

\section{Literature:}

Brubaker, Rogers: "Ethnicity without groups". Arch.Europ. Sociology: XLIII, 2, 2002, pp. 163-189.

Elwert, Georg: "Nationalismus und Ethnizität: Über die Bildung von Wir-gruppen”. Kölner Zs. F. Soziologie und Sozialpsychologie, Jg. 41. H.3, 1989, pp. 440-464.

Campbell, Donald T.: "Ethnocentric and other altruistic motives". In: Levine, David (ed.): Nebraska symposium on motivation. University of Nebraska Press: Lincoln 1965, pp. 283-311.

Esser, Hartmut: "Ethnische Konflikte als Auseinandersetzungen um den Wert von kulturellem Kapital”. In: Heytmeyer, Wilhelm / Dollnase, Reiner (eds.): Die 
bedrängte Toleranz. Ethnische Konfklikte, religiöse Differenzen und die Gefahren politischer Gewalt. Suhrkamp: Frankfurt a. Main 1996, pp. 63-92.

Giles, Howard / Bourhis, Richard Y. / Taylor, Donald M: “Towards a Theory of Language in Ethnic Group Relations". In: Howard Giles (ed.): Language, Ethnicity and Intergroup Relations. Academic Press: London 1977, pp. 307-348.

Hansen, Georg / Spetsmann-Kunkel, Martin: Integration und Segregation - Ein Spannungsverhältnis. Waxmann: Münster - New York - München - Berlin 2008.

Hartsch, Edmund: Maffay - Auf dem Weg zu mir. Bertelsmann: München 2009.

Hofstätter, Peter R.: Gruppendynamik. Kritik der Massenpsychologie. Rowohlt: Hamburg 1957.

Kotthoff, Helga: "Lernersprachliche und interkulturelle Ursachen für kommunikative Irritationen”. Linguistische Berichte 135, 1991, pp. 375-397.

Krüger, Diane: "Quand le lion a commencé à rugir». L'identité flamande et la Première Guerre Mondiale. MA-Thesis, Europa-Universität Viadrina, Frankfurt (Oder) 2004. Unpublished.

Popova, Ekaterina: Sprachen und interethnische Beziehungen in Estland in der Umbruchszeit (Diss. Europa-Universität Viadrina, Frankfurt Oder). (in print)

Rom-Sourkova, Olga: Die sprachliche Situation in der Russischen Föderation: Gesetzgebung und Wirklichkeit. BWV, Berliner Wissenschafts-Verlag, 2004.

Sherif, Muzafer: The Psychology of Social Norms. Harper: Oxford, England 1936.

Sherif, Muzafer et al.: Intergroup conflict and cooperation: The robbers cave experiment. University of Oklahoma Book Exchange: Norman 1961.

Nassim, Nicholas Taleb: Antifragile: Things That Gain from Disorder. Random House: New York 2012.

Tajfel, Henri: "An integrative theory of intergroup conflict". In: Austin, Wiliam. G. / Worchel, Stephen (eds.) The social Psychology of Intergroup Relations. Brooks/Cole: Monterrey, California 1979, pp. 33 - 47.

Tajfel, Henri: Gruppenkonflikt und Vorurteil. Entstehung und Funktion sozialer Stereotypen. Mit einem Vorwort von Wolfgang Stroebe. Huber: Bern / Stuttgart / Wien 1982.

Weber, Max: Wirtschaft und Gesellschaft. Mohr: Tübingen 1922.

Weydt, Harald: "The Principle of Equal Effort and its Role in Language Conflicts Canada, Khazakhstan and Europe”. Revue Education et Sociétés Bilingues 3, Dezember 1997, pp. 69 - 80.

Weydt, Harald: "Welche Sprachen in den europäischen Institutionen? (Kiun lingvon en la europaj institucioj?)". Internationale Zeitschrift für Modellierung und Mathematisierung in den Humanwissenschaften 39, Heft 2, Juni 1998, pp. 69-80. 
Weydt, Harald: “Pourquoi les conflits linguistiques?”. In: Weydt, Harald (ed.): Langue - Communauté - Signification. Approches en Linguistique Fonctionnelle. Lang: Frankfurt am Main et al. 2002, pp. 39-47.

Weydt, Harald: "The Inferiority of the Non-native Speaker and its Political Consequences". In: Ryan, Phyllis M. / Terborg, Roland (eds.): Language: Issues of Inequality. Universidad Nacional Autónoma de México 2003, pp. 172-188.

Weydt, Harald: "Le choix de langues scolaires dans une région bilingue. L'exemple de Kazaquestane”. In: Feuillard, Colette (ed.): Créoles - Langages et Politiques linguistiques. Lang: Frankfurt am Main et al. 2004, pp. 315-321.

Weydt, Harald: “Sprachkonflikte - unvermeidlich aber beherrschbar?” In: Jańczak, Barbara / Jungbluth, Konstanze / Weydt, Harald (eds.): Mehrsprachigkeit aus deutscher Perspektive. Narr: Tübingen 2012, pp. 9-29.

Weydt, Harald (forthcoming): "Sprache oder Dialekt?" 



\section{Boundaries and language islands}





\author{
Peter Rosenberg \\ (Frankfurt/Oder)
}

\title{
Anything goes? The gains and losses of the constructivist view on ethnicity: Some considerations based on German „language islands“ studies.
}

\begin{abstract}
Sprachinseln leben von der „Grenze“, von ihrer Abgrenzbarkeit. Wenn die Grenze schwindet, gehen sie in der Flut unter. Was macht die Konstruktion der „Grenze“ stabil, was labil?

Deutsche Sprachinseln in Russland und Brasilien zeigen gegenwärtig einen deutlichen Abbau der Sprachinselvarietäten und einen rapiden Sprachwechsel zur Mehrheitssprache. Dieser Abbau läuft allerdings keineswegs amorph, sondern geregelt ab und bewahrt Kernfunktionen, etwa in der Kasusmorphologie. Die sprachliche Entwicklung in den Sprachinseln ist weniger durch Konvergenzen aus den Kontaktsprachen und -varietäten geprägt, sondern folgt eher - unter starker Beschleunigung - dem auch im Binnendeutschen üblichen Sprachwandel.

Es fragt sich daher, was diese dramatische Beschleunigung auslöst? Soziolinguistisch erweist sich als Motor des Wandels eine Auflösung von „Normativität“, von Normwissen und Normloyalität. Zweitsprachler des Deutschen überwiegen gegenüber Muttersprachlern; Code-mixing gewinnt an Boden gegenüber Code-switching, Zuwanderung stärkt die Kontaktsprache. Die Sprachinselvarietäten dienen immer weniger einem ethnischen „boundary marking“ (Barth 1969). Der Konstruktion ethnischer Grenzen fehlen zunehmend die Ressourcen: Ethnische Grenzen diffundieren und die Sprachinseln geraten in Auflösung. „Untergehende“ Sprachinseln lassen nicht nur Sprachwandelprozesse wie im Labor erkennen, sondern vermitteln auch soziolinguistische und kulturanthropologische Erkenntnisse, worin die Konstruktion des ethnischen „boundary (un)marking“ besteht.
\end{abstract}

Schlagworte: Sprachinseln, Sprachwandel, Morphologie, Ethnizität, boundary marking, Konstruktivismus

Keywords: language islands, language change, morphology, ethnicity, boundary marking, constructivism

Boundaries - at least from the perspective of postcolonial studies - are always blurred boundaries: both sides always have something in common (for example, the border), and the more interesting subject is usually the construction of the border rather than the border itself. A border is typically seen as a bare construction. But what does it mean: a construction? How and to which end do we con- 
struct boundaries, and what kind of resources are needed to successfully construct boundaries? This will be discussed on the basis of some findings in „language island" (Sprachinsel) research.

The very existence of language islands is related to boundary marking. They depend on their distinctiveness. Language islands are more or less distinct linguistic communities within a limited area; they have tight networks and an awareness of their distinctiveness, which marks a certain difference from the surrounding linguistic community. Conversely, if the boundary vanishes, the island is swept away by the floods: their inhabitants are assimilated into the majority society, adopting the contact language.

Since we are concerned with the linguistic fate of language islands ,in the flood“, we have to ask: What makes the construction of linguistic boundaries stable and what makes it unstable?

Let's have a look at a case of obsolescence ${ }^{1}$ of language islands, a process which starts with some degree of boundary diffusion, and ends with language shift. At the moment, we observe a period of language change induced by intense language contact, but structured by language internal processes. That's what is occurring in some language islands in Russia and Brazil today.

In the following section, an empirical observation of linguistic simplification and change will be presented. Afterwards, some theoretical explanations on boundary marking will be discussed.

\section{The linguistic problem: Language islands in the flood}

The goal of our research ${ }^{2}$ is to study language use in German-speaking communities with some degree of disintegration of the speech community, which leads to morphological simplification in the form of case reduction. Our credo is that this story of

1 Cf. Dorian, Nancy: „Introduction“. In: Dorian, Nancy (ed.): Investigating obsolescence. Studies in language contraction and death. Cambridge University Press: Cambridge et al. 1989 , pp. $1-10$.

2 The research was done among language islands in the area of Pelotas, Rio Grande do Sul, Southern Brazil, with the East Low German Pomeranian and the West Central German Hunsrück varieties, and in the Altai region in West Siberia, Russia, with the West Upper German Katholisch and the East Low German Plautdietsch varieties. 125 speakers of three age-groups (younger than 40 years, $40-59$, older than 60 years) have been recorded, 61 in Russia (27 speakers of Plautdietsch, 34 of „Katholisch“) and 64 in Brazil ( 39 speakers of Pomerano, 25 of Hunsrückisch). Since the data has been collected one half each in the 1990ies and in the 2000s (until 2011) it was possible to include 23 recordings of the same speakers after 10-13 years. 
language decomposition - just as well as language composition - tells us something about the structure of language, since the process is not at all amorphous or chaotic.

We compare two language islands each in Brazil and Russia (High German and Low German varieties), with speakers living in close contact with the majority population. The persecutions of the past have resulted in diminishing numbers among the speech communities, and the liberalizations that followed have diminished their distinctiveness and led to a process of assimilation, especially among the younger generations.

\subsection{Some findings about linguistic change in the language islands in Russia and Brazil}

Linguistically, we observe - like in other countries ${ }^{3}$ - case reduction in regular morphology, but case maintenance in irregular morphology. Just a few examples will be given to illustrate case marking after dative input in a translation task, where speakers were asked to translate standard German input into the language island dialect.

Reduction of case morphology to -(e)n or - $e$ (or - $\varnothing$ ) is very frequent in noun inflection. As the following examples show especially dative is subject to reduction.

(1) ick heff löcher in mine schoine strömp ${ }^{4}$ ('Ich habe Löcher in meinen schönen Strümpfen' - I've got holes in my nice stockings)

(2) an maine noas hengt'n dropp ('An meiner Nase hängt ein Tropfen' - A drop hangs from my nose.)

(3) dei hoor op minen kopp sin grau. ('Die Haare auf meinem Kopf sind grau' The hairs on my head are grey.)

3 For example the United States: cf. the contributions of Salmons, Keel, Huffines in Berend, Nina / Mattheier, Klaus J. (eds.): Sprachinselforschung. Eine Gedenkschrift für Hugo Jedig. Peter Lang: Frankfurt a. M. 1994; or more recently: Boas, Hans C.: „Case Loss in Texas German: The Influence of Semantic and Pragmatic Factors“. In: Barðdal, Jóhanna / Chelliah, Shobhana Lakshmi (eds.): The Role of Semantics and Pragmatics in the Development of Case. Benjamins: Amsterdam, Philadelphia 2009, pp. 347-373.

4 Transcription in accordance to Schröder, Ingrid / Ruge, Jürgen / Bieberstedt, Andreas: Forschungsprojekt „Hamburgisch - Sprachkontakt und Sprachvariation im städtischen Raum". Hamburger Transkriptionskonventionen. Hamburg 2011: Universität Hamburg, retrieved 22.7.2015, from https://www.slm.uni-hamburg.de/niederdeutsch/forschung/ projekte/hamburgisch-sprachkontakt/ hamburger-transkriptionskonventionen.pdf, on a HIAT base, cf. Ehlich, Konrad / Rehbein, Jochen: „Halbinterpretative Arbeitstranskriptionen (HIAT)“. In: Linguistische Berichte 45, 1976, pp. 21-41. Examples given here are recorded from Pomerano speakers in Brazil. 
The use of $d e n /-n$ as a default for all kinds of oblique case marking is common and well attested also for neuter:

(4) mi braure hett den schååp gråås jejeft (,Mein Bruder hat dem Schaf Gras gegeben - My brother has given grass to the sheep.)

(5) den letste jåår (,das letzte Jahr c - the last year)

(6) wi derfe in den hus rinnegåån (,Wir dürfen in das Haus hineingehen - We may go into the house)

What is shown in Fig. 1 is case distinction in regular morphology (noun inflection: nouns, determiners, adjectives, demonstrative and possessive pronouns):

Fig. 1: Regular morphology (noun inflection): Realization of dative input. (Translation task, 125 speakers, $n=6218$ ) $[D=$ dative realization, $-=$ no case ending (for instance de), $N=$ nominative, $A=$ accusative, $N A=$ common form for nominative and accusative (die), $D A=$ common form for dative and accusative, $+=$ additional form, $0=$ no realization $]$.

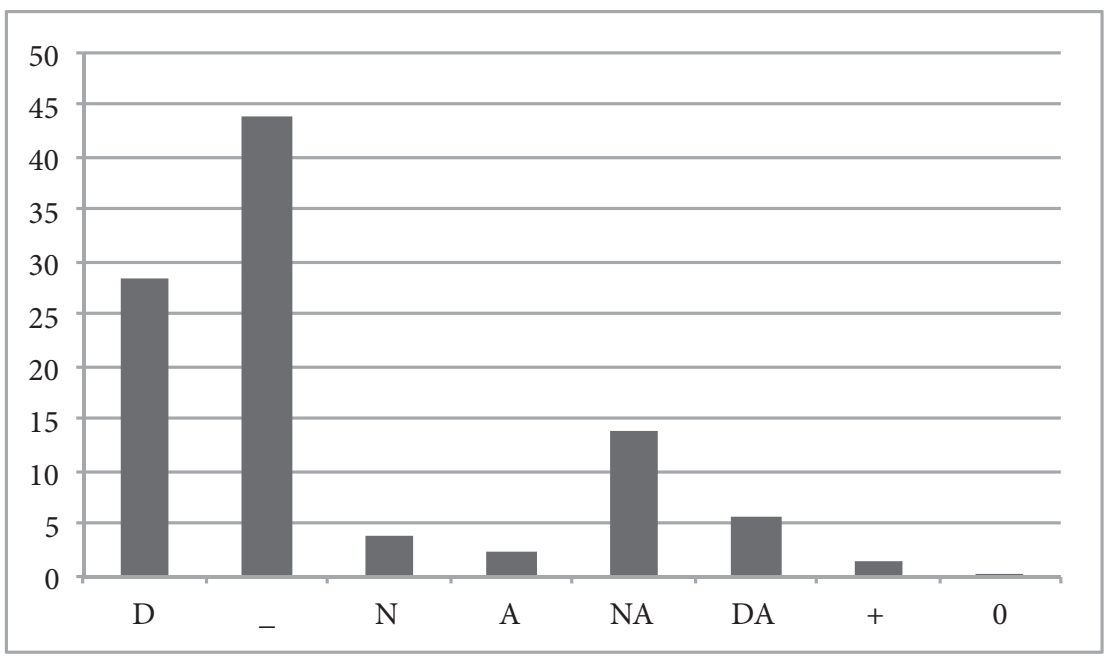

It's obvious that less than one third of the data is translated into dative output.

Fig. 2 and 3 compare case marking in adjectives on dative and accusative input. Both figures are very similar: dative and accusative are realized with the same endings: a predominant common case (NA). Case marking is vanishing in noun inflection of the language islands observed. 
Anything goes? The gains and losses of the constructivist view on ethnicity 153

Fig. 2: Adjective inflection: Realization of dative input. (Translation task, 125 speakers, $n=699$ )

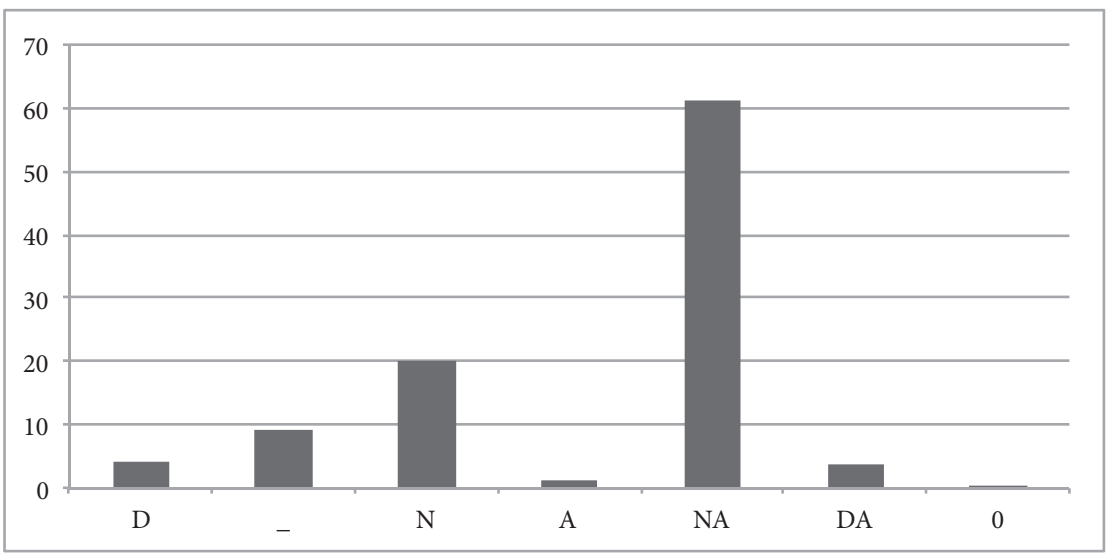

Fig. 3: Adjective inflection: Realization of accusative input. (Translation task, 125 speakers, $n=766$ )

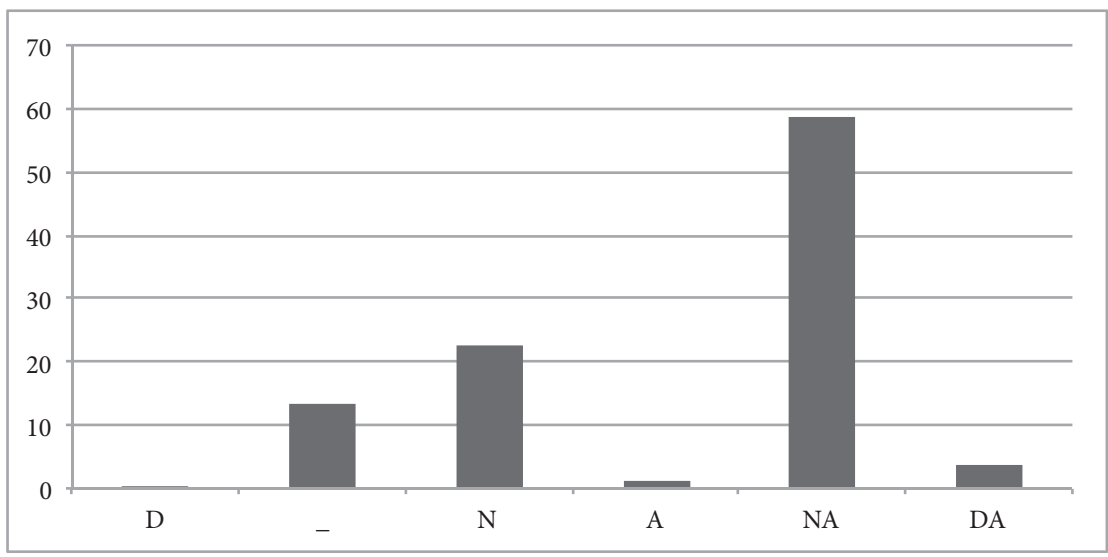

The examples (1) - (6) given above are taken from Low German speakers, but the same structure is found in all recordings of all varieties in both countries with only small differences as fig. 4 reveals: 
Fig. 4: Adjective inflection by varieties: Realization of dative input ( $n=699)[H R X=$ Hunsrückisch, KAT = „Katholisch“, $P O M=$ Pomerano, $P D T=$ Plautdietsch $]$

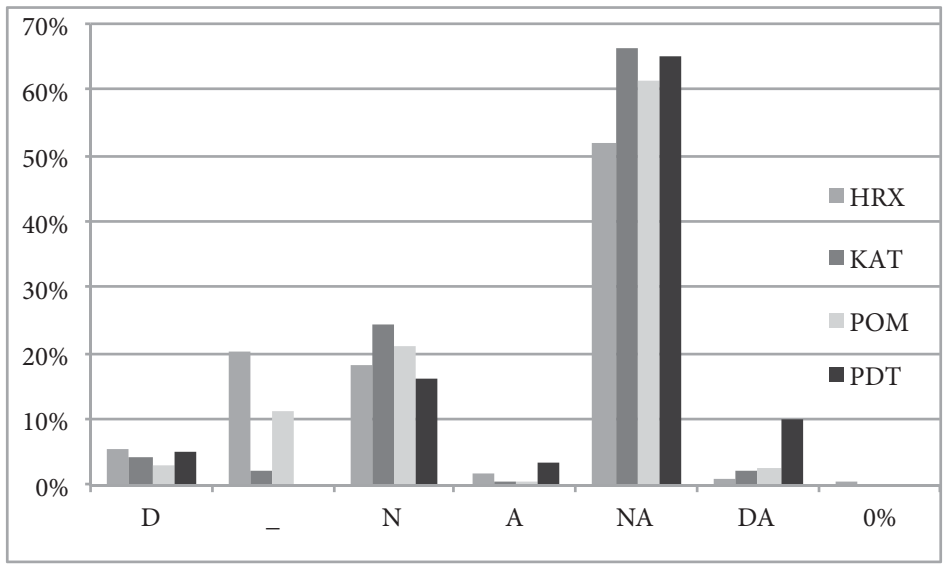

While dative is only rarely produced in noun inflection, it is very frequent in personal pronoun inflection: A clear difference with about two thirds of the data reflecting dative output is presented in Fig. 5.

Fig. 5: Irregular morphology (personal pronoun inflection): Realization of dative input. (Translation task, 125 speakers, $n=986$ ) $[D=$ dative realization, $-=$ no case ending, $N=$ nominative, $A=$ accusative, $N A=$ common form for nominative and accusative (sie), DA = common form for dative and accusative (euch), + = additional form, $0=$ no realization]

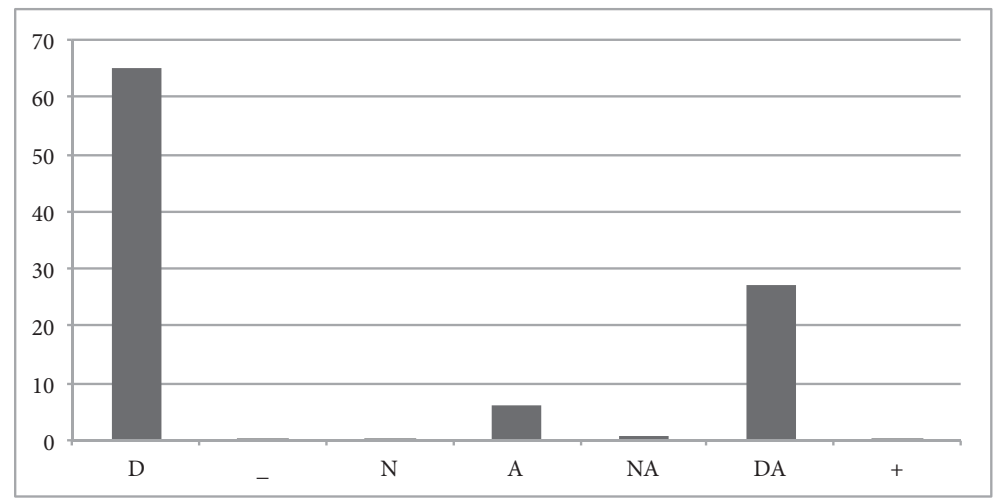

5 The high proportion of $D A$ (oblique case marking) is represented mostly by the Low German personal pronouns $m i$ or di for standard German 'mir/mich' or 'dir/dich' ('me'). 
However, speakers often change word class in their output when replacing personal pronouns ( $i h m$, ihr 'him, her') with demonstrative pronouns (dem, der 'this.DAT'), and then use the accusative (den, die 'this.AKK'), which they frequently do when case-marking regular forms. This would not be noteworthy since change of word class is common in many varieties of German. But only fifty years ago, Jedig ${ }^{6}$ stated that for the Mennonite Plautdietsch in Russia, dative is the main (oblique) case with determiners. 50 years later, this has changed dramatically, with only one third using dative and the other two thirds replacing it with a common case or accusative.

\subsection{Accelerated, but ordinary change}

These changes emerge in all varieties observed, not only in those communities with intense contact to the majority language or to another German variety. That's why convergence is not very likely to serve as an explanation of this kind of change. Case reduction occurs in communities with a morphologically „rich“ contact language (Russian), as well as with a "poor“ one (Brazilian Portuguese), in morphologically more „conservative“ varieties (Low German dialects), as well as in others (High German dialects). Of course, there are some differences - Low German dialects are morphologically more "stable“ - but the varieties share the same tendencies.

Hence, the case reduction presented above appears to be an accelerated - but ordinary - linguistic change all German varieties are subject to, not essentially a matter of contact-induced adoption or convergence. While in irregular inflection, the case system is rather stable, regular case morphology is radically simplified: The outcome is a reduction of case marking endings to $-(e) n /-e^{7}$, which represents the German weak noun inflection system expanded even to the strong inflection paradigm. In most cases there is no longer any case marking.

Personal pronouns reveal more case distinction for different reasons $s^{8}$, the most important being their high frequency, their animate referents, their "full listing"

6 Jedig, Hugo H.: Laut- und Formenbestand der niederdeutschen Mundart des AltaiGebietes. (= Sitzungsberichte der Sächsischen Akademie der Wissenschaften zu Leipzig. Philologisch-historische Klasse. 112/5). Akademie-Verlag: Berlin 1966, p. 52.

$7 \quad-n$ as default when marking oblique case, $-e$ for common case.

8 Cf. Salmons, Joseph: „Naturalness and Morphological Change in Texas German“.In: Berend, Nina, Mattheier, Klaus J. (eds.): Sprachinselforschung. Eine Gedenkschrift für Hugo Jedig. Peter Lang: Frankfurt a. M. 1994, pp. 59-72, p. 64; Rosenberg, Peter: „Dialect convergence in German speech islands". In: Auer, Peter / Hinskens, Frans / Kerswill, Paul E. (eds.): Dialect Change. Convergence and Divergence in European Languages. Cambridge University Press: Cambridge et al. 2006, pp. 221-235. 
mental representation as monomorphematic words and words with irregular word formation?.

The reduction of grammatical distinctions in the language islands observed could be interpreted as a kind of degrammaticalization, which is structured by case semantics: dative is maintained with personal pronouns in its "core function" as the case of the animated receiver ${ }^{10}$.

But what might be the sociolinguistic explanation of the acceleration of change?

\subsection{The sociolinguistics of change}

Change in the Brazilian language islands is more intense, but the Russian language islands catch up quickly. The process of assimilation began earlier in the Brazilian German communities, but it is more rapid in the Russian German communities.

The Brazilian society is multiethnic, and the German speaking minority is only one of a hundred ethnic communities. From the beginning, the German colonists have been „aliens“ by mission: For about 100 years, they kept their distance to the surrounding population in terms of geography, language, culture, economy, religion and social structure. Since about 1940, „Brazilianization“ has emerged, unifying the country (at least related to the „white“ Brazilians), in the last decades modernizing the society, and, hence, lowering the barriers of social contact. For a long time, the maintenance of the minority language and culture depended on the autonomous settlement. The German-speaking settlements, however, became subsequently integrated into the society. ${ }^{11}$ Today, Brazilian Germans are primarily Brazilians, speaking Brazilian Portuguese, married with Brazilians of other ethnic descent, studying somewhere in the country. Among the younger ones, the German language has become a heritage language. The disintegration of the language islands began two generations ago. Nowadays, ethnic diversity is a familiar trait of all people but it is not a vital resource of social distinction.

The former USSR was - by constitution as well as by societal awareness based on ethnicity. Experience was matched by this kind of ethnic framing.

9 Cf. Cholewa, Jürgen: „Störungen der lexikalisch-morphologischen Wortverarbeitung bei Aphasie: Ein Literaturüberblick“. Neurolinguistik 7 (2), 1993, pp. 105-126.

10 Cf. Jakobson, Roman: „Beitrag zur allgemeinen Kasuslehre. Gesamtbedeutungen der russischen Kasus“. In: Travaux du Cercle Linguistique de Prague 6: Études Dédiées au Quatrième Congrès de Linguistes, Prague 1936. Jednota Československých Matematiku a Fysiku: Praha 1936; Harassowitz: Leipzig, pp. 240-288.

11 The colonies in the Pelotas surrounding, for instance, have been connected to the city of Pelotas by a „fasche“, an asphalt road, in the 1970s. 
Language served as a boundary marker since it represented a difference: the experience of communicative belonging (as long as "compact groups“ were demarcated ${ }^{12}$ by language and code alternation ${ }^{13}$ structures were established) as well as of social or cultural difference. This was even true in the deportation camps and guarded villages.

German settlement in the USSR has always been discontinuous. The manifold migrations (voluntarily or not) of the Russian Germans have not affected the ethnically based system of belonging. However, the construction of „central villages" with different German varieties spoken enhanced the expansion of Russian among the younger generation: A former study ${ }^{14}$ in a Siberian village revealed that for intergroup communication, Russian has displaced German, but not for intragroup conversation. In intragroup communication, Mennonites, for instance, used exclusively German to a degree of about $60 \%$, in intergroup communication of only $20 \%$. In a network study we found school children divided into network clusters of Mennonite Low German-speaking pupils, a Volga German variety speaking pupils („Lutherisch“), and an Upper German variety speaking pupils („Katholisch“). Interactions across these clusters were made in Russian, since the children had no Standard German at their disposal as a means of communication.

12 As Andreas Dulson studied in extremely heterogeneous German villages on the river Volga, linguistic change depends on the "compactness" of linguistic communities: As long as „compact groups" are felt to face each other, linguistic varieties represent these entities and convergence or divergence take place. If boundaries become diffuse in heterogeneous contact settings with intersecting boundaries, change will accelerate feature by feature, and the effect of normative behavior decreases. Cf. Dulson, Andreas: „Problema skreschtschenija dialektow po materialam jasyka nemzew Powolshja". In: Iswestija Akademii nauk Sojusa SSR, Otdelenie literatury i jasyka 3, 1941, pp. 82-96, p. 93.

13 Huffines showed this for Non-Sectarians among Pennsylvania-Germans: Non-Sectarians with a habitual code-switching behavior had less English interference, while Sectarians communicating only in German had far more interference. Cf. Huffines, Marion L.: „Case usage among the Pennsylvania German sectarians and nonsectarians". In: Dorian, Nancy (ed.): Investigating obsolescence. Studies in language contraction and death. Cambridge University Press: Cambridge et al. 1989, pp. 211-226, pp. 222 f.

14 Cf. Rosenberg, Peter: „Sprachgebrauchsstrukturen und Heterogenität der Kommunikationsgemeinschaft bei den Deutschen in der GUS - eine empirische Studie“. In: König, Peter-Paul / Wiegers, Helmut (eds.): Satz - Text - Diskurs. Akten des 27. Linguistischen Kolloquiums, Münster 1992. Bd. 2. Niemeyer: Tübingen 1994, pp. 287-298, p. 294. The study covered 749 queries, including the whole school youth and every fifth inhabitant of the village of Podsosnowo, now Rayon Halbstadt, Altai region. 
Since the breakdown of the Soviet Union, a disruptive language shift emerged among Russian Germans because of the mass emigration of resettlers („Aussiedler") to Germany in the 1990s. Today, the majority language is dramatically expanding in public and private domains. Younger generations are quickly shifting to Russian, code-mixing is more frequent than code-switching, and the proportion of second-language learners outweighs native speakers. Intermarriage is steadily increasing, and getting vocational education outside of the village is common. Additionally, the ethnic composition of the villages is becoming more diffuse because of the replacement of the emigrated resettlers by non-Germans or non-regionals (immigrating Germans from the Central Asian republics of the former USSR). Today, only about $15 \%$ of the villagers are locally born and network clusters are dissolving. Being German is not a primary distinction anymore.

Some traits of an accelerated disintegration of the Russian language islands can be detected from our sociolinguistic background information as far as language is concerned:

If asked whether the speakers use the contact language (Russian or Brazilian Portuguese) with their parents, Russian Germans predominantly answer not at all (more than Brazilian Germans). But with their children, Russian Germans use Russian only or frequently by a clear majority.

Fig. 6: Family domain of language usage: Speaking contact language with parents in Brazil and Russia $(n=60)^{15}$

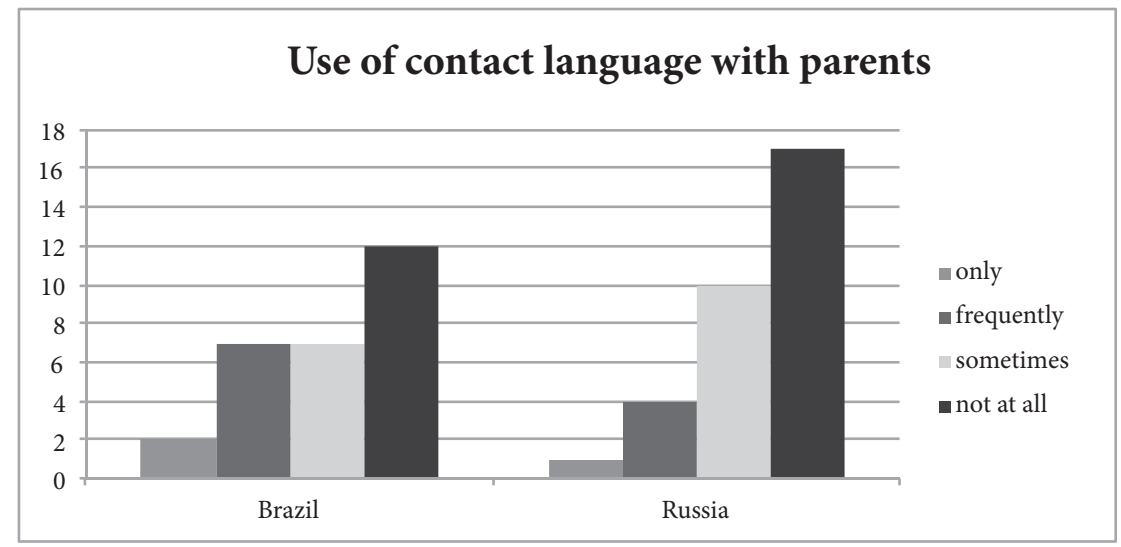

15 The 60 respondents are only the speakers interviewed in the 2000s. 
Fig. 7: Family domain of language usage: Speaking contact language with oldest child in Brazil and Russia $(n=54)$

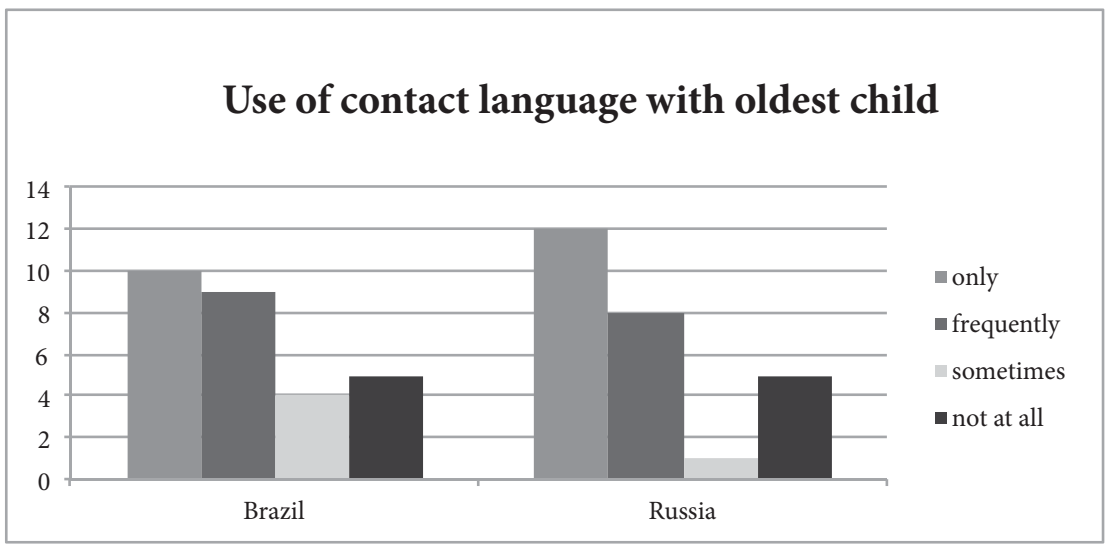

At work, Russian Germans use Russian most frequently, which was not the case in former times, when almost $100 \%$ of the villagers were of German descent.

Fig. 8: Public domain of language usage: Speaking contact language at work in Brazil and Russia $(n=61)$

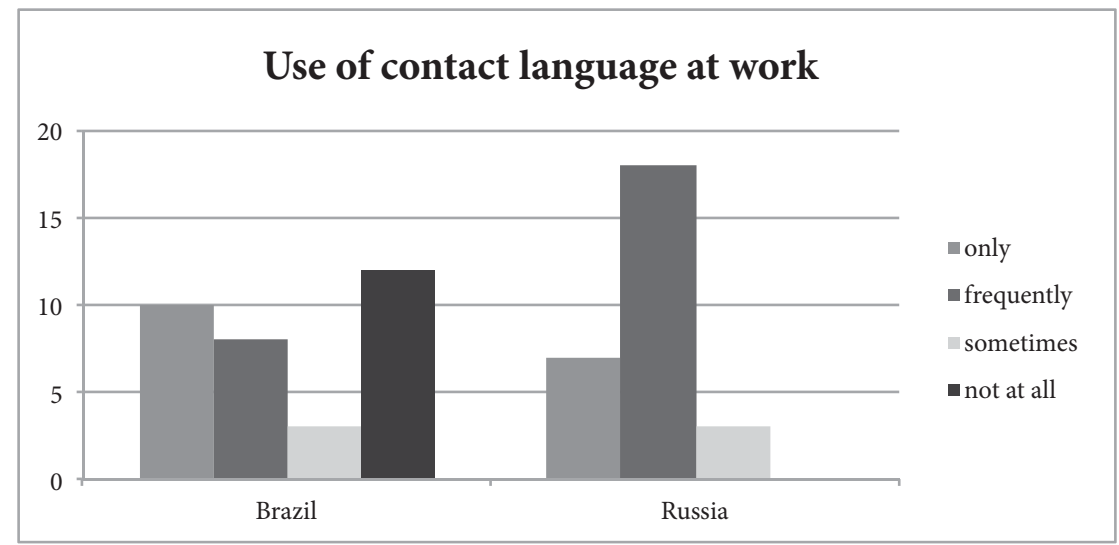

What is striking in our findings is that the acceleration in language change in the Russian-German language islands is not simply a consequence of language contact and imposition. What we find is a loss of something different: the gradual loss of knowing and caring about what is linguistically „ours“ and what is „theirs“. This is connected to a lack of intergenerational transmission of the German language, 
an increasing proportion of non-native speakers, a common practice of codemixing (frequently without any awareness of using elements of two languages). The determining factor which might have opened the gate for change in these communities could be called a loss of „normativity“, i.e. of norm awareness and norm loyalty. And this brings about the problem of boundary marking and the (linguistic) resources to construct boundaries.

\section{The socio-cultural problem: the diffusion of boundaries}

Usually, Fredrik Barth, the "father" of ethnological constructivism, ought to be invoked at this point in the discussion: „The critical focus of investigation from this point of view becomes the ethnic boundary that defines the group, not the cultural stuff that it encloses. "16

Ethnic boundaries are not "given“ by the essence of origin, language or culture, but constructed by choice and evaluation of social relations. Brubaker, too, warns against the tradition of "groupism", which takes (ethnic) groups for "things in the world“ instead of a shared and imagined "groupness". They are "what we want to explain, not what we want to explain things with" (Brubaker 2002, p. 165) Again, the task of constructing ethnic groups - like language islands - is under discussion, not the task of ethnicity as a category based on some commonalities. ${ }^{17}$

How can ethnic boundaries be constructed?

The notion of construction has become widely accepted in the social sciences. From the point of view of language island research, however, we still have to answer some questions: What are the resources of ethnic boundary marking? Are they chosen arbitrarily? Do boundary markers constructed by ascription result from mere imagination? Are ethnic constructions basically grounded in stereotypes? Are feelings of ethnic belonging expressions of a "false consciousness“, indoctrinated by ethnic entrepreneurs? What is essentialism? And may the most important question be: What is the impact of experience?

16 Barth, Fredrik: Ethnic Groups and Boundaries. The social organization of culture difference. Universitets Forlaget: Bergen, Oslo 1969; Allen and Unwin: London, p. 16.

17 However, this important differentiation between ethnic group and category is given up at the end, when Brubaker suggests: „In other words, by raising questions about the unit of analysis - the ethnic group - we may end up questioning the domain of analysis: ethnicity itself.“ (Brubaker, Rogers: „Ethnicity without groups“. In: Archives Européennes de Sociologie XLIII.2, 2002, pp. 163-189, p. 186) 
We rely on at least some approaches to these tasks, since the language islands mentioned above are subject to a landslide-like diffundation of ethnic boundaries.

Barth himself, has admitted some oversimplifications when reviewing his approach in 1969 at a 25-year anniversary conference in 1993: The main objections have been the following:

- The claim, it wouldn't be the „cultural stuff“ which defines the ethnic group, but the boundary was „overstated“, and thus „people’s choice of diacritica appeared arbitrary“18.

- These diacritica of boundary marking are not constructed by a „mere act of imagining“", but rather have „empirical properties ${ }^{\text {“19: }}$ : they are based on „experience“, and reflect „salient, major cultural discontinuities ${ }^{\text {“20. }}$.

- In this sense, „ethnicity is the social organization of culture difference ${ }^{\text {(221. }}$.

Now, what is construction?

Instead of disregarding the role of experience ${ }^{22}$ and culture, I would suggest taking construction as a threefold process of selection of experiential features (making them "focused“ in terms of Le Page/Tabouret-Keller ${ }^{23}$ ), their hierarchization (making them relevant) and - as far as attitudes are involved - their evaluation (making them highly valued) ${ }^{24}$.

18 Barth 1994, p. 12.

19 Barth 1994, p. 13.

20 Barth 1994, p. 14.

21 Barth 1994, p. 13

22 Emphasizing experience is not essentialism, but requires a link between ascription and experiential rooting of social categories. „All the evidence indicates that there was always in the Soviet Union [sic!] a level of individual discrimination that ensured a wealth of personal experience of ethnic identity as a salient fact of life." (Barth 1994, p. 27).

23 Cf. Le Page, Robert B. / Tabouret-Keller, Andrée: Acts of Identity. Creole-based approaches to language and ethnicity. Cambridge University Press: Cambridge et al. 1985.

24 It may well be, that (social, cultural ...) evaluation serves as a guideline to select the diacritica of boundary marking. This objection reflects a debate on attitude structure: Rosenberg and Hovland argue for a threefold structure of attitudes including cognitive, evaluative or affective, and behavioral components of attitudes, while others see evaluation as the core of this structure which affects even the cognitive „beliefs" related to the subject, cf. Rosenberg, Morris J. / Hovland, Carl I.: „Cognitive, Affective, and Behavioral Components of Attitudes“. In: Rosenberg, Morris J. / Hovland, Carl I. (eds.): Attitude Organization and Change. Yale University Press: New Haven 1960, pp. 1-14.; Tesser, Abraham / Shaffer David R.: „Attitudes and attitude change“. In: Annual Review of Psychology 41, 1990, pp. 479-523, p. 481. 
Since experience is often interpreted within ethnic dichotomies, they are frequently given the structure of stereotypes. We have to ask, then, if ethnicity is only conceivable in the framework of stereotypes, and therefore inadequate.

This is widely held when linguistic terms are assumed to be means of „othering“: generating the subject of categorization and therefore "excluding“ the „othered“. Instead, the construction of ethnicity rather seems to be prototypical.

A differentiation between category, stereotype and prototype would define a category to be a selection of features that hold for all members of the set, a stereotype, a selection of features that are over-generalized to all members of the set, and a prototype - a selection of features that applies to the most valid or central exemplar of the set. ${ }^{25}$

Construction seems to be organized prototypically: The most valid member is chosen by salience, and that's where experience comes in. Some features are more applicable than others to serve as diacritica of social categories. Language is one of the more salient ones, and quite often it is - in an implicational way - the „focal center of our acts of identity“26.

However, in the language islands presented above, linguistic distinctions lose their boundary-marking function. Thus, we have to ask: under which circumstances does language serve as an ethnic boundary marker, under which does it lose this ability? And what could explain the acceleration of language change in the Russian-German language islands?

\section{Ethnic boundary (un)marking, disintegration of the linguistic community and language change}

The answer is a threefold: language is an ethnic boundary marker if it serves a communicative need (in some language domains), if it displays a certain distinctiveness, and if it is considered a legitimate distinction within an ethnic frame, i.e. if social experience is reasonably focused as an ethnic structure with prototypical actors of relevant „ethnic“ characteristics.

As is shown in section 1.3, in the Russian-German language islands, the German varieties do not support ethnic boundary marking in a distinctive way. Since the inhabitants of the villages have largely been replaced by non-locals, Russian has become the dominant language. The former social structure has fundamentally changed: Until the mass migration of the 1990s, Mennonites, Catholics and

25 Hybridity does not affect this ethnic framing per se, since hybrid identities are contextspecific variations which are related to prototypes.

26 Le Page/Tabouret-Keller 1985, p. 248. 
Protestants largely determined the village structure, each using German varieties in intragroup communication, but Russian in intergroup communication. Today, there is nothing other than „intergroup“ communication because of the influx of Germans from the Middle Asian countries. Russian is used in all linguistic domains (except speaking with grand parents and elder people). Therefore, there is no need to communicate in German. Language - the focal „act of identity“ in former times - has become a means of diffusion: Linguistic behavior of even middle-aged speakers is Russian-based or Russian-German code-mixing. Ethnic boundaries are going to vanish since the experience of difference is less prominent, since language loses the ability to focus this experience, and since differences no longer represent an ethnic "loading“.

Normativity decreases and borders become diffuse - not when oppression is most severe, but when language and cultural stuff lose their discreteness. Then, the disintegration of the linguistic community - and sometimes accelerated linguistic change - is the consequence. Losing boundaries is akin to losing norm awareness, norm institutions and norm loyalty, which opens the door to obsolescence and simplification. Mattheier ${ }^{27}$ drew attention to the conditions of the fading of norms: (a) the degree of target norm awareness, (b) the degree of norm codification, (c) the degree of norm tolerance, $(d)$ the perceived difference between in-group and outgroup norm.

This is what we observe in these language islands losing their distinctiveness from generation to generation: The norm awareness is diffusing among younger speakers (a), it is not codified like all dialects, not even in relation to a German diasystem (b). Most importantly, second language learners are the majority of German speakers, without any corrections from fully competent speakers (c), and constant code-mixing blurs linguistic differences (d). Thus, fading linguistic norms may lead to the loss of ethnic boundaries.

Is this process inevitable? Or is Barth ${ }^{28}$ right after all with his remark that vanishing cultural difference "does not correlate in any simple way with $[\ldots]$ a breakdown in boundary-maintaining processes?“

He is right, of course: It is no simple path, but requires a new framework. Esser argues for two preconditions for this new framework: a change in utility and

27 Mattheier, Klaus J.: „Allgemeine Aspekte einer Theorie des Sprachwandels“. In: Sprachgeschichte. Ein Handbuch zur Geschichte der deutschen Sprache und ihrer Erforschung. 2., vollst. neu bearb. u. erw. Aufl. Hrsg. v. Werner Besch u. a. Erster Teilband. (= Handbücher zur Sprach- und Kommunikationswissenschaft. 2.1). de Gruyter: Berlin, New York 1998, pp. 824-836, p. 834.

28 Barth 1969, pp. $33 \mathrm{f}$. 
a change in attitudes ${ }^{29}$. An ethnic frame serves to profit from ethnic capital - as a "specific" capital only useful for the ones that "possess" ethnic legitimacy. Attitudes have to serve as a reasonable explanation of experience. To acquire a certain degree of "groupness", you have to bring about some distinctiveness. Utility and distinctiveness of language may support an ethnic framing. In Russia, the language island varieties lose both their utility and their distinctiveness. Language change is accelerated by a rapid decay of linguistic normativity and a de-ethnicizing of the social setting.

In modern societies, the great unifiers - state, market and democracy loosen ethnic boundaries, which is now also the fate of our language islands in ,inundation“.

The island metaphor focuses the linguistic, and sometimes social, cultural, religious, difference from the outside. However, it hides the fact that the inhabitants of the island do not die by losing their linguistic heritage, but live on happily and successfully speaking the language of the majority. And they have their reasons for doing so.

\section{Bibliography}

Barth, Fredrik: Ethnic Groups and Boundaries. The social organization of culture difference. Universitets Forlaget: Bergen, Oslo 1969; Allen and Unwin: London.

Barth, Fredrik: „Enduring and emerging issues in the analysis of ethnicity“. In: Govers, Cora/Vermeulen, Hans (eds.): The Anthropology of Ethnicity. Beyond "Ethnic Groups and Boundaries“. Het Spinhuis: Amsterdam 1994, pp. 11-32.

Berend, Nina / Mattheier, Klaus J. (eds.): Sprachinselforschung. Eine Gedenkschrift für Hugo Jedig. Peter Lang: Frankfurt a. M. 1994.

Boas, Hans C.: „Case Loss in Texas German: The Influence of Semantic and Pragmatic Factors". In: Barðdal, Jóhanna / Chelliah, Shobhana Lakshmi (eds.): The Role of Semantics and Pragmatics in the Development of Case. Benjamins: Amsterdam, Philadelphia 2009, pp. 347-373.

Brubaker, Rogers: „Ethnicity without groups“. In: Archives Européennes de Sociologie XLIII.2, 2002, pp. 163-189.

Cholewa, Jürgen: „Störungen der lexikalisch-morphologischen Wortverarbeitung bei Aphasie: Ein Literaturüberblick“. Neurolinguistik 7 (2), 1993, pp. 105-126.

29 Esser, Hartmut: „Die Definition der Situation“. In: Kölner Zeitschrift für Soziologie und Sozialpsychologie 48, 1996, pp. 1-34. 
Anything goes? The gains and losses of the constructivist view on ethnicity 165

Dorian, Nancy: „Introduction“. In: Dorian, Nancy (ed.): Investigating obsolescence. Studies in language contraction and death. Cambridge University Press: Cambridge et al. 1989, pp. 1-10.

Dulson, Andreas: „Problema skreschtschenija dialektow po materialam jasyka nemzew Powolshja“. In: Iswestija Akademii nauk Sojusa SSR, Otdelenie literatury i jasyka 3, 1941, pp. 82-96.

Ehlich, Konrad / Rehbein, Jochen: „Halbinterpretative Arbeitstranskriptionen (HIAT)“. Linguistische Berichte 45, 1976, pp. 21-41.

Esser, Hartmut: „Die Definition der Situation“. Kölner Zeitschrift für Soziologie und Sozialpsychologie 48, 1996, pp. 1-34.

Huffines, Marion L.: „Case usage among the Pennsylvania German sectarians and nonsectarians". In: Dorian, Nancy (ed.): Investigating obsolescence. Studies in language contraction and death. Cambridge University Press: Cambridge et al. 1989, pp. 211-226.

Huffines, Marion L.: „Directionality of Language Influence: The Case of Pennsylvania German and English“. In: Berend, Nina / Mattheier, Klaus J. (eds.): Sprachinselforschung. Eine Gedenkschrift für Hugo Jedig. Peter Lang: Frankfurt a. M. 1994, pp. 47-58.

Jakobson, Roman: „Beitrag zur allgemeinen Kasuslehre. Gesamtbedeutungen der russischen Kasus". In: Travaux du Cercle Linguistique de Prague 6: Études Dédiées au Quatrième Congrès de Linguistes, Prague 1936. Jednota Československých Matematiku a Fysiku: Praha 1936; Harassowitz: Leipzig, pp. 240-288.

Jedig, Hugo H.: Laut- und Formenbestand der niederdeutschen Mundart des AltaiGebietes. (= Sitzungsberichte der Sächsischen Akademie der Wissenschaften zu Leipzig. Philologisch-historische Klasse. 112/5). Akademie-Verlag: Berlin 1966.

Keel, William D.: „Reduction and Loss of Case Marking in the Noun Phrase in German-American Speech Islands: Internal Development or External Interference?" In: Berend, Nina / Mattheier, Klaus J. (eds.): Sprachinselforschung. Eine Gedenkschrift für Hugo Jedig. Peter Lang: Frankfurt a. M. 1994, pp. 93-104.

Le Page, Robert B. / Tabouret-Keller, Andrée: Acts of Identity. Creole-based approaches to language and ethnicity. Cambridge University Press: Cambridge et al. 1985.

Mattheier, Klaus J.: „Allgemeine Aspekte einer Theorie des Sprachwandels“. In: Sprachgeschichte. Ein Handbuch zur Geschichte der deutschen Sprache und ihrer Erforschung. 2., vollst. neu bearb. u. erw. Aufl. Hrsg. v. Werner Besch u. a. Erster Teilband. (= Handbücher zur Sprach- und Kommunikationswissenschaft. 2.1). de Gruyter: Berlin, New York 1998, pp. 824-836. 
Rosenberg, Morris J. / Hovland, Carl I.: „Cognitive, Affective, and Behavioral Components of Attitudes“. In: Rosenberg, Morris J. / Hovland, Carl I. (eds.): Attitude Organization and Change. Yale University Press: New Haven 1960, pp. 1-14.

Rosenberg, Peter: „Sprachgebrauchsstrukturen und Heterogenität der Kommunikationsgemeinschaft bei den Deutschen in der GUS - eine empirische Studie“. In: König, Peter-Paul, Wiegers, Helmut (eds.): Satz - Text - Diskurs. Akten des 27. Linguistischen Kolloquiums, Münster 1992. Bd. 2. Niemeyer: Tübingen 1994, pp. 287-298.

Rosenberg, Peter: „Comparative speech island research: Some results from studies in Russia and Brazil“. In: Keel, William / Mattheier, Klaus J. (eds.): Deutsche Sprachinseln weltweit: Interne und externe Perspektiven. German Language Varieties Worldwide: Internal and External Perspectives. Peter Lang: Frankfurt a. M. et al. 2003, pp. 199-238.

Rosenberg, Peter: „Dialect convergence in German speech islands“. In: Auer, Peter / Hinskens, Frans / Kerswill, Paul E. (eds.): Dialect Change. Convergence and Divergence in European Languages. Cambridge University Press: Cambridge et al. 2006, pp. 221-235.

Salmons, Joseph: „Naturalness and Morphological Change in Texas German“. In: Berend, Nina / Mattheier, Klaus J. (eds.): Sprachinselforschung. Eine Gedenkschrift für Hugo Jedig. Peter Lang: Frankfurt a. M. 1994, pp. 59-72.

Schröder, Ingrid / Ruge, Jürgen / Bieberstedt, Andreas: Forschungsprojekt „Hamburgisch - Sprachkontakt und Sprachvariation im städtischen Raum“. Hamburger Transkriptionskonventionen. Hamburg 2011: Universität Hamburg, retrieved 22.7.2015, from https://www.slm.uni-hamburg.de/niederdeutsch/ forschung/projekte/hamburgisch-sprachkontakt/hamburger-transkriptions konventionen.pdf.

Tesser, Abraham / Shaffer David R.: „Attitudes and attitude change“. Annual Review of Psychology 41, 1990, pp. 479-523. 
Hans C. Boas

(Texas)

\title{
Linguistic splits along religious lines: The role of language maintenance among Catholics and Lutherans in Texas
}

\begin{abstract}
Dieser Beitrag beschäftigt sich mit der Frage, inwieweit bedrohte Sprachen und Dialekte vom Aussterben bewahrt werden können. Die konkrete Fallstudie beschäftigt sich mit dem Texas Deutschen, welches seit mehr als 150 Jahre in Zentraltexas gesprochen wird und zu Beginn des 21. Jahrhunderts vom Aussterben bedroht ist. Ein Vergleich der Sprachsituation in evangelischen und katholischen Gemeinden soll zeigen, wie die beiden Religionsgemeinschaften sich in der Bewahrung des Deutschen als Kirchensprache unterschiedlich entwickelt haben. Anhand von Interviews aus dem Texas German Dialect Archive wird auch die Rolle des Englischen besprochen, welches im Laufe des 20. Jahrhunderts aufgrund historisch-politischer Ereignisse immer mehr an Bedeutung gewonnen hat.
\end{abstract}

Schlagworte: Sprachkontakt, Sprachtod, Texas Deutsch, Sprache und Religion

Keywords: Language contact, language death, Texas German, language and religion

\section{Introduction}

Previous research on language maintenance suggests that endangered languages and dialects have a better chance of surviving when they are continuously used in religious contexts (see Grenoble and Whaley 1998). Just like other important domains such as schools, media, and public administration, religion can thus play an important role in maintaining endangered languages. This paper investigates the role of religion on language maintenance by discussing differences in language maintenance patterns between German-speaking Catholics and Lutherans in Texas between 1850 and today. The goal is to see how long these groups used German at church and to determine the various reasons for giving up German in religious contexts in favor of English.

The remainder of this paper is structured as follows. Section 2 gives a brief overview of German immigration to Texas. Section 3 presents the organization and workflow of the Texas German Dialect Project (TGDP), whose recordings of interviews with some of the remaining speakers of Texas German (TxG), a critically endangered dialect, form the basis for our investigation. Section 4 investigates how German was used as a church language by Catholics and Lutherans 
from 1850 until today, highlighting the role of English and the prestige of Standard German. Section 5 presents a summary of our findings.

\section{German immigration to Texas}

The first large wave of German-speaking immigrants arrived in the early 1840s, and large-scale immigration continued for a number of decades thereafter (with a brief interruption during the Civil War). ${ }^{1}$ The majority of German-speaking immigrants settled in what later became known as the "German belt", which encompasses the area between Gillespie and Medina Counties in the west, Bell and Williamson Counties in the north, Burleson, Washington, Austin, and Fort Bend Counties in the east, and DeWitt, Karnes, and Wilson Counties in the south.

By 1860 there were nearly 20,000 German-born immigrants, mostly from northern and central Germany, living in Texas, and approximately 30,000 Texas Germans, including the American-born children of immigrants (Jordan 1966). Although German immigration to Texas eventually tapered off, the number of Texas Germans continued to increase: by 1940 there were approximately 159,000 Texas Germans (Kloss 1977). For the first several decades of German settlement in Texas, the Texas Germans were relatively isolated, thanks to a number of political and/or social factors. This isolation, coupled with serious attempts at language maintenance, allowed for the retention of TxG. There were numerous Germanlanguage church services, newspapers and other periodicals, schools, and social organizations (ranging from choirs to shooting clubs) (Jordan 1966). This situation eventually changed dramatically, starting with the passing of an English-only law for public schools in 1909 (Salmons 1983, p. 188). World War I, especially following America's entry into the war in 1917 and the resulting increase in antiGerman sentiment, dealt a major blow to TxG, leading to the stigmatization of German and the beginning of its decline. World War II reinforced the stigma attached to Germany, Germans, and the German language. Institutional support for German was largely abandoned; German-language newspapers and periodicals stopped publishing altogether or switched to English as the language of publication; some German-language schools closed and German instruction was dropped in others; and German-speaking churches replaced German-language services with English-language ones (see Boas 2005). The following figures from Nicolini (2004) show how the use of German and English changed from the 1920s to the 1940s. Figure 1 illustrates how the numbers of attendees at English-speaking

1 This section is based on Boas et al. (2010). For a general history of Texas, see Campbell (2003). 
church services increased in the Texas District of the American Lutheran Church from about 5,900 in 1931 to around 11,000 in 1948. At the same time, the number of attendees at German-speaking church services declines from about 5,800 to around 1,000. These numbers clearly illustrate the declining role that German played at church services during that period.

Figure 1: Number of attendees at English-speaking and German-speaking church services in the Texas District of the American Lutheran Church (ALC) (Nicolini 2004, p. 100).

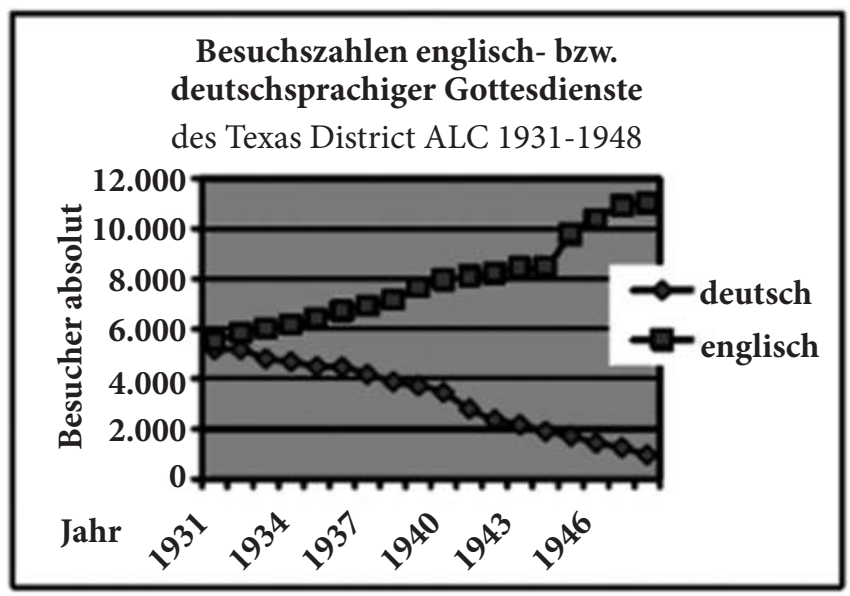

Nicolini (2004) describes a similar trend in the use of English and German at Sunday school. Figure 2 below shows the distribution of German-only, English-only, and mixed language Sunday schools in combined congregations of the German Texas-Synod and the Texas District of the American Lutheran Church. They show that in the early 1920s there were a roughly equal number of German-only and English-only Sunday schools (with English-only slightly more that German-only), slightly under 40 congregations in each category. In contrast, there were about 30 mixed language Sunday schools. These numbers changed quite drastically over the next 18 years, with no German-speaking Sunday schools left by 1940. In contrast, the number of English-only Sunday schools drastically increased from slightly fewer than 40 in 1922 to close to 180 . This drastic change in numbers is not only due to the fact that many congregations decided to switch the language at Sunday schools from German to English, but it is also caused by the drastic increase in population and churches in Texas during that period. Based on oral history interviews, I show in Section 4 below that these changes did not happen evenly in all parts of Texas. Instead, there was a significant divide between rural 
and urban areas, as well as between areas with a high concentration of German speakers vs. areas with few German speakers.

Figure 2: Language use at Sunday schools of congregations of the German Texas-Synod and the Texas District of the American Lutheran Church (Nicolini 2004, p. 99).

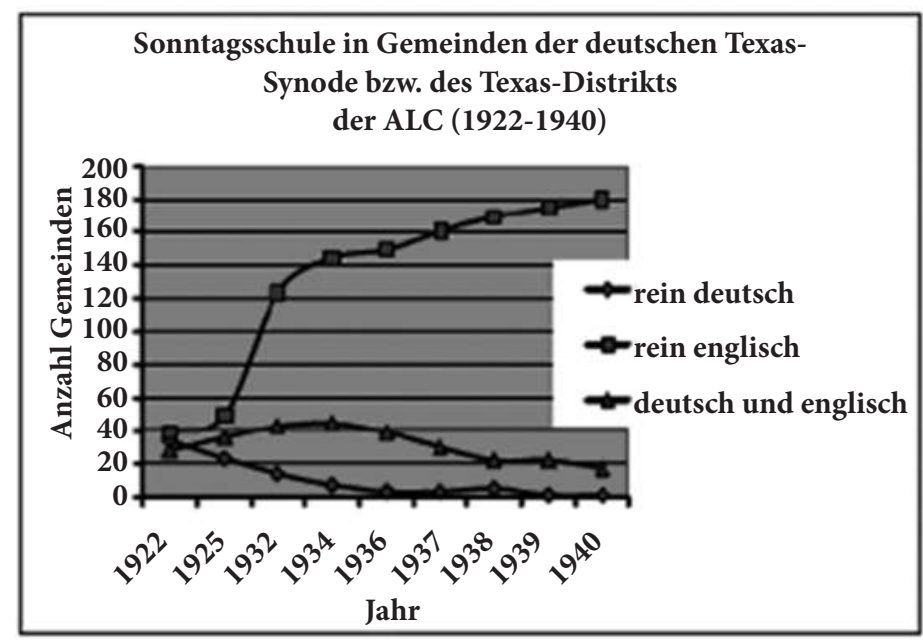

The end of World War II brought additional challenges to the maintenance of German language and culture in Texas. Speakers of English moved in increasing numbers to the traditional German enclaves, and generally refused to assimilate linguistically to their new neighbors by learning German, leading to the largescale abandonment of German in the public sphere. At the same time, younger Texas Germans left the traditional German-speaking areas for employment or education, and began to speak primarily English. Texas Germans also increasingly married partners who could not speak German, and English typically became the language of the household in such linguistically mixed marriages; children raised in such households usually have at best a very limited knowledge of TxG. Finally, the development of the American interstate highway system in the 1950s made the once-isolated TxG communities much more accessible, making it easier for non-German speakers to visit or live in previously monolingual German communities, and for German-speakers to accept employment in more urban areas. Both of these possibilities led to the spread of English at the expense of German.

Despite these factors, in the 1960 s there were still approximately 70,000 speakers of TxG. Today only an estimated 8,000-10,000 Texas Germans, primarily in their sixties or older, still speak the language of their forbearers fluently (Boas 
2009), and English has become the primary language for most Texas Germans in all domains. With no signs of this shift to English being halted or reversed and fluent speakers almost exclusively above the age of 60 , TxG is expected to die out within the next 30 years (Boas 2009). ${ }^{2}$

\section{Methodology}

In addition to more recent smaller-scale studies like Salmons (1983) and Guion (1996), a large-scale study has been under way since 2001, when I founded the Texas German Dialect Project (www.tgdp.org). Besides re-recording translations of word and sentence lists based on Eikel (1954) and Gilbert (1972), members of the TGDP have conducted open-ended sociolinguistic interviews with more than 450 of the approximately 6000 remaining speakers of Texas German (all of whom are 60 years or older). The recorded interviews are transcribed and translated, and subsequently uploaded, together with the relevant metadata for each speaker and interview, to the TGDA, where they can be accessed over the Internet at [http:// www.tgdp.org] (for details, see Boas (2006) and Boas et al. (2010)). The transcripts of the open-ended sociolinguistic interviews can be searched on-line with the help of a concordance tool, which allows users to search for particular keywords and their relevant contexts. The data for this paper come from the open-ended sociolinguistic interviews stored in the TGDA. In addition, I rely on data from the biographical questionnaires (see Boas et al. 2010) to determine how much English and German was spoken at church during the speakers' lives.

\section{German as a church language among Catholics and Lutherans in Texas}

\subsection{The early period: 1845 - 1917}

New Braunfels (halfway between present-day San Antonio and Austin) was the first town founded in Texas by the Adelsverein immigrants in 1845. The distribution of German-speaking Catholics and Lutherans was roughly one third to two thirds, as the immigrants came from areas where both religions were prevalent (Biesele 1930). The lack of infrastructure in Texas during the early years necessitated cooperation between adherents of both faiths, including a shared Easter service under a tree in 1845, and the building of the so-called "Vereinskirche"

2 See Nicolini (2004) for a considerably more optimistic outlook on the possible fate of TxG. 
in Fredericksburg in 1847. The "Vereinskirche" served a dual mission: First, as a church for Catholics and Lutherans, who held church services at different times. Second, to serve as a school building in which the children received an education. As was the case in most frontier settlements during the early years, the clergy were also the teachers instructing the children at school (Biesele 1930, Nicolini 2004).

The shared space arrangements changed quickly in the early 1850s when Catholics and Lutherans built their own churches, sent calls for missionaries to Germany, and opened German-speaking Sunday schools (see Nicolini (2004) for more information on Methodists, Mormons, and other religions). While Catholics continued as a coherent group, Lutherans began to splinter into different groups, largely because of differences in opinion of specific religious matters (see Nicolini 2004). What is important, however, is that throughout the $19^{\text {th }}$ century and the early $20^{\text {th }}$ century, almost all Lutheran churches with a majority of Germanspeaking members continued to use (Standard) German at church (as well in Sunday schools). ${ }^{3}$ In contrast, the Catholic congregations in German-speaking areas would use Latin for the service, and German for the sermon and prayers as the following report from speaker 45 (interviewed by the TGDP) shows:

My friends were all mostly Catholic. And one had to go to church always on Sundays, and every morning. That was the convention in those days. Every morning! From about seven to seven thirty, and then we went to school. The church was here and the school was here, across the street. Well, first to church and then school. Sometimes I was rather late to church, but I had to go nonetheless. That was different than it is today. Twelve years we went there. Now the school is only eight years, and then they go to public school. They have mini-mass, just a priest and one or two helpers. There were also usually one or two church-related assignments in school, which were given by nuns. They were all so good and wonderful. I believe the people who went there all learned well, and it didn't hurt them at all to have gone there. It has changed since then, I don't remember when. The service was in Latin, but the sermon and some of the other prayers were in German. Then

3 It is important to note that the language used for official occasions at church was Standard German, which was the high prestige language in the Texas German community, as opposed to Texas German (a collection of various immigrant dialects in contact with each other, and in the process of accommodation during the $19^{\text {th }}$ and early $20^{\text {th }}$ centuries), which was the low-prestige language variety used in informal situations. Space constraints prohibit a detailed discussion of these matters, but see Nicolini (2004), Salmons and Lucht (2006), and Boas (2005 / 2009) for more information. 
it completely went to English — that was hard. 1945 they stopped the German, I would say. Probably had a lot to do with the wars, but I don't know. (1-45-1-10 $)^{4}$

The early $20^{\text {th }}$ century was an important period for the use of German in Texas churches for four major reasons. First, Standard German was well established as the prestige variety in the public domain in German-speaking communities across central Texas. It was used in churches, in schools, and in newspapers (Salmons 1983, Boas 2009). Of course, this varied from community to community, depending not only on the ethnic mix of the population, but also on whether the community was in a rural setting or an urban one. While the population of some Texas Hill Country settlements like Fredericksburg and New Braunfels was $96 \%$ German-speaking, other towns such as La Grange and Weimar only had about a third of the population speaking German.

Second, a law passed by the Texas legislature in 1905 required the use of English as the instructional language in public schools (Heinen 1982, Boas 2009). However, as Blanton (2004) notes, many local authorities ignored this requirement for many years, especially in cases where the overwhelming majority of the community spoke only German. The State of Texas could not find any easy way to enforce these laws since in many cases the members of the school boards were exclusively Germanspeaking. More importantly, this school law was not relevant to parochial schools, which were typically run by nuns, who spoke German to their students.

Third, after reaching a peak in the 1880s and 1890s, immigration of Germanspeaking immigrants dropped significantly in the first decade of the $20^{\text {th }}$ century, while the numbers of first- and second-generation native-borns increased significantly (Wilson 1977). At the same time, more and more German-speaking Texans became exposed to English through schooling and contact with English speakers. This development led to a growing demand for the inclusion of English in churches, in particular in areas where the majority of the population spoke English as their first language (Nicolini 2004, Boas 2009).

Fourth, the first decade of the $20^{\text {th }}$ century already saw a subtle switch from German to English as church language. One major factor in this was religious affiliation. Some Catholic churches switched to English (while still holding on to Latin for the service itself), because many members in their congregations did not speak German. Instead, they came from a Czech-, Spanish-, or Polish-speaking background.

4 Numbers following excerpts from the interviews are unique numbers of interview sections stored in the online Texas German Dialect Archive at [http://www.tgdp.org]. Users can access the archive, listen to the original recording of the interview in Texas German, and read the transcript and English word-by-word translation. 
A switch to English was thus necessary to keep the operation of these congregations viable. Another major factor was the rural vs. urban divide. In order to attract other non-German-speaking Catholics, many churches decided to switch to English, especially in larger towns and cities (see Nicolini 2004 for details).

\subsection{Times of crisis and decline: 1917-1950}

The entry of the U.S. into World War I in 1917 triggered a wave of anti-German hysteria. German-Americans changed their names to English-sounding names (Schmidt to Smith, Müller to Miller, etc.) and stopped speaking German in public. A 1918 law "introduced the regulation that all teachers in public free schools should teach in English only and should use only English text books" (Kloss 1998, p. 228). The results of this school law are remembered by one TGDP speaker from Fredericksburg as follows:

We were all German, and none of us could speak English. For three years we learned German when I was in school. Then it came to an end. We also learned the old German writing. I wish I had upheld that, so that I could know the ABC's for reading and writing. We would still speak German at school, but first of all we had to speak English. There'd be trouble if the teacher heard us speaking German instead of English. There was more trouble during the First World War. The Germans around here weren't well regarded by the others. (1-21-1-5)

In addition to affecting the language of school instruction, anti-German sentiments spread throughout the public sphere. Officially licensed committees at the county level, called "council of defense", were charged with supporting the war effort in any possible way, including ideological proclamations about language and culture. One such example is the Goliad County Council of Defense, which published the following proclamation in 1917:

It is strongly urged by the Council of National Defense and we concur in that suggestion that the English language be made the means of communication in all public matters and in all private conversation, except where it would work a hardship on those who are unable to speak the English language. We recommend that this be brought about, not by force, but by a proper educational campaign in which it should follow as a matter of spontaneous, patriotic duty that the people would speak the English language. Patriotic citizens of German descent will readily appreciate the delicacy of the situation which makes it necessary that the English language be used in this country upon all occasions and by all people except in those instances of a private nature where they are unable to speak the English language.

All these developments had drastic effects on the Texas German community, including the use of German in the public, in churches, in newspapers, in social 
organizations, and in schools. While many Catholic congregations, especially in cities and in areas with mixed ethnic populations, had already switched to English prior to the war, the continued use of German by Lutherans throughout and after World War I caused controversy. For most Lutherans, using the German language at church had religious significance since it was the language into which Martin Luther had translated the bible (Nicolini 2004). Thus, many Lutherans believed that they could only have a connection to the church and God through German, and not English. Because of this direct link between language and religion, Lutheranism more generally became a principle target of nativist hostility during World War I. For example, the Comal County Council of Defense noted in July 1918 that "the Lutheran preacher is being closely watched, and we almost had him; and we're going to get him yet." Similarly, members of the Bosque County Council of Defense proclaimed the following in June 1918:

German preachers caused more trouble by their actions and suggestions than anybody else. (...) People are naturally suspicious of anything German, the mere fact of holding any kind of services in German arouses suspicion which is not good.

This anti-German sentiment held by most Americans of Anglo descent (and hence English speaking) was so strong that many Lutheran congregations were afraid of using German at church. However, a switch to English would have meant for many elderly Lutherans that they could not understand church services anymore because their command of English was often nonexistent. Faced with this dilemma, many Lutheran congregations sought special permission to use German at church, so that they would not be regarded as un-American. One such example is a special request from the congregation of St. John's Lutheran church to the Bell County Council of Defense in June 1918:

Permission asked to consider allowing German language services because the nonEnglish speaking members will be without any and all spiritual edification. A ban on German will create hardships of mothers and fathers who have given their sons gladly for our country and deprive them of the consolidation of God's word in the language they best know and understand. The Evangelical Lutheran Church has nothing to do with the German government.

Despite the fact that most German-speaking Texans were American patriots supportive of the war effort, using German in sermons was often regarded as a sign of support for the enemy (Nicolini 2004). Thus, even though German-speaking soldiers from Texas fought for the U.S. in World War I, it was seen as suspicious to hold a sermon in German at the burial of one of these soldiers. One case that 
stands out is a proclamation of the Victoria Council of Defense in July 1918, which condemned the use of German at such a sermon:

Who kept these people from reading, speaking, and talking English, and who kept them from attending a church where the English language was preached, prayed, and spoken? An American soldier was buried by their pastor in Victoria, Texas, and the funeral rites were conducted in German, and a German sermon was preached over his body. (...) It is the German mind, the German heart, and the German tongue, of which we disapprove ... We are fighting Germany, German soldiers, German methods, German ideas and everything conceivably German.

To summarize, the general anti-German sentiment first manifested itself in the public sphere, especially via English-only laws for public schools. During and after the war it also manifested itself in the pressure on German-speaking Lutheran congregations (as well as those Catholic congregations that had not yet switched to English) to discontinue the use of German at church. In the decades following the war, most churches that had not already switched to English during the war, discontinued church services in German in favor of English. In some cases, especially in cities and in areas where German speakers were in the minority, congregations decided to switch abruptly from German-only to English-only church services. In other cases, especially in rural areas and in areas with a high percentage of German speakers, this development was more gradual. It would typically start out with only one English church service per month and three German church services, going to two English and two German church services, and three English and one German church service. At the end of this process, which in some cases took only a few years and in other cases twenty or more years, there would only be occasional church services in German on special occasions such as Easter or Christmas (Nicolini 2004). One TGDP speaker from Crawford recounts how the strong anti-German sentiment led to the gradual discontinuation of German church services:

I can't say exactly how it happened back during the First World War. There were some American people who were so angry because some people were speaking German. Not in all places, but in Pottsville, Predien, and such places, they said everybody better speak English from now on - we're at war, and it's not American, and so on: 'You are not allowed to speak German anymore.' Man, they brought that out... Many got so angry that they parted from each other, or they acted as interluders between Americans and Germans. But here in Hamilton County, so many people were German. And then people said, Well, you can't have German in the Church or in the school anymore, 'but we were all German except for one family, who didn't go to our church. Eventually we had three weeks of German services in church, one in English. Then we had two weeks in German, two in English, and then three weeks in English and one in German. Then more English people 
came into our community, you see. And then finally we only had German services four times a year, and now it's just once a year at Christmas. (1-64-1-13)

Another TGDP speaker from Doss, west of Fredericksburg, recalls the move from German to English and its effects on language maintenance as follows:

We were Lutheran. My oldest brother and my oldest sister - when they went to confirmation, they had to learn it in German. But when we went, it was all in English. It was totally different. Because of that, I never learned how to read or write German. I can read it when it's written in the English typeset, but not in the German type. Church was always in German. And then, little by little, one time they would have service in German, one time in English, one time in German, once in English. Our preacher - earlier - was always from Germany, and they could preach really well in German. Later on, they could not do that anymore - they could speak German. Not well enough to preach in front of a bunch of people. I think that the war - World War II - brought that on to a great degree. Because when I was going to school, German was forbidden. It just forced people to talk English. Of course, we still spoke it at home. I wish I had more time, and had more chances, to speak the German. I know I've forgotten a lot of things. These last few days I've thought about German a lot. And a lot of words I haven't spoken in maybe forty years, I think, came back all at once! (1-55-1-9)

Another interesting point about the use of English and German in different domains during the early 1930s concerns the use of the two languages at church and at school. One TGDP speaker, from Freyburg (north of Schulenburg), recounts how her pastor also taught school in the early 1930s, and that there was a strict separation between which language was used for which purpose:

The church school was a Lutheran school. We had a pastor for a schoolteacher. First it was Pastor [name], but he died. He was riding a horse and it threw him off and he broke his neck. I can still remember that very well, where it happened and everything. Then we had Pastor [name] for the high school, the community school. The pastor taught us in English, but he could also speak German. He always preached in German. The whole church was all in German. I knew the Our Father and everything in German. The Pastor never preached in English in the church, but we had to speak English in school, because it was the Second World War then. You know, there was a lot of hatred against Germans then, even though we were in the United States. $(1-7-1-7)^{5}$

While the period between the two world wars was characterized by a relative calm regarding sentiments against German speakers in Texas, World War II brought on another loss of prestige for German. For example, while there were still a significant number of "all German" and "more German" church services in Missouri

5 The names of the pastors are not included for privacy reasons. 
Synod Lutheran churches before World War II, the use of German was basically discontinued after World War II, as Figure 3 below shows.

Figure 3: Language use for Missouri Synod Lutherans, 1909-1955 (Salmons \& Lucht 2006, p. 169)

\begin{tabular}{|c|c|c|c|c|c|c|c|}
\hline Year & $\begin{array}{c}\text { All } \\
\text { German }\end{array}$ & $\begin{array}{c}\text { More } \\
\text { German }\end{array}$ & $50 / 50$ & $\begin{array}{c}\text { More } \\
\text { English }\end{array}$ & $\begin{array}{c}\text { All } \\
\text { English }\end{array}$ & $\begin{array}{c}\text { Span / } \\
\text { Span-Eng }\end{array}$ & $\begin{array}{c}\text { Total Texas } \\
\text { congregations }\end{array}$ \\
\hline 1909 & \multicolumn{2}{|c|}{97} & \multicolumn{2}{|c|}{13} & 3 & & 113 \\
\hline \multirow[t]{2}{*}{1919} & 32 & 28 & 13 & 10 & 18 & & 101 \\
\hline & 3405 & 9217 & 1427 & 2273 & 675 & & \\
\hline \multirow[t]{2}{*}{1922} & 39 & 31 & 21 & 9 & 32 & & 132 \\
\hline & 4834 & 8346 & 2222 & 2253 & 1467 & & \\
\hline \multirow[t]{2}{*}{1925} & 27 & 23 & 25 & 24 & 35 & & 134 \\
\hline & 3256 & 8429 & 3961 & 3952 & 1499 & & \\
\hline \multirow[t]{2}{*}{1928} & 10 & 30 & 34 & 26 & 38 & & 138 \\
\hline & 2270 & 8254 & $5 \sqrt[4]{47}$ & 4938 & 2227 & & \\
\hline \multirow[t]{2}{*}{1932} & 7 & 21 & 36 & 30 & 49 & & 143 \\
\hline & 1063 & 7002 & 6295 & 6946 & 3677 & & \\
\hline \multirow[t]{2}{*}{1935} & 4 & 27 & 35 & 26 & 50 & & 142 \\
\hline & 540 & 8848 & 7539 & 4560 & 3859 & & \\
\hline \multirow[t]{2}{*}{1940} & 2 & 10 & 37 & 24 & 81 & & 154 \\
\hline & 619 & 4421 & 7623 & 5605 & 11762 & & \\
\hline 1945 & \multicolumn{5}{|c|}{37} & 8 & 164 \\
\hline 1950 & \multicolumn{5}{|c|}{27} & II & 205 \\
\hline 1955 & \multicolumn{5}{|c|}{17} & 10 & 226 \\
\hline
\end{tabular}

Based on data from the Statistical Yearbook of the Evangelical Lutheran Synod, Salmons and Lucht (2006) calculate language use in churches belonging to the Missouri Synod. The numbers of the first line represent congregations, while the italicized numbers on the second line reflect total membership. The numbers up to 1940 show a drastic drop of German language use right after World War I, then a slow decline during the interwar years, and finally a complete switch to English in 1945 (except the ones where Spanish is still used). This statistical trend is also supported by a TGDP speaker from Spring Branch, north of San Antonio, who recounts the abrupt end to German church services in the late 1940s.

Then the Blanco and Bulverde churches joined together, and for me it was more convenient to go to Bulverde than Blanco, so I went there, and I'm still a member at the Lutheran church to this day. Same church all of us in this corner belong to. When the first church was down there, then everything was in German; and the women sat on one side and the men sat on the other side. And when one of our friends was engaged with a young man, she went in to church and sat down right next to him. She was the first woman who dared that. And then all the other women also started sitting with their husbands; on average, 
you know. In my memory, we didn't have a German-speaking minister. Since 1949 or 1948. It's all been just English since then. But at that old church, there was German - the old Church down by Cibolo everything was in German. The first minutes- the first writings from the church, you know, they were all in German. (1-51-1-10)

\subsection{The end of regular German church services}

Based on the data from Salmons and Lucht (2006), it is safe to say that today German is not used in Lutheran churches in Texas any more. There are some exceptions, such as the occasional German Christmas service at St. Martin's Lutheran Church in Austin. Another Lutheran church in Houston offers regular church services in German, but these are mostly attended by recent immigrants from Germany or by expats who spend a few years in Houston before returning to Europe. Based on all available information, there is also no regular German church service in Texas Catholic churches any more. The death of German as a church language in Texas also becomes apparent when looking at biographical data collected by the TGDP.

Figure 4: Reports of German spoken at Church (Boas 2009, p. 65)

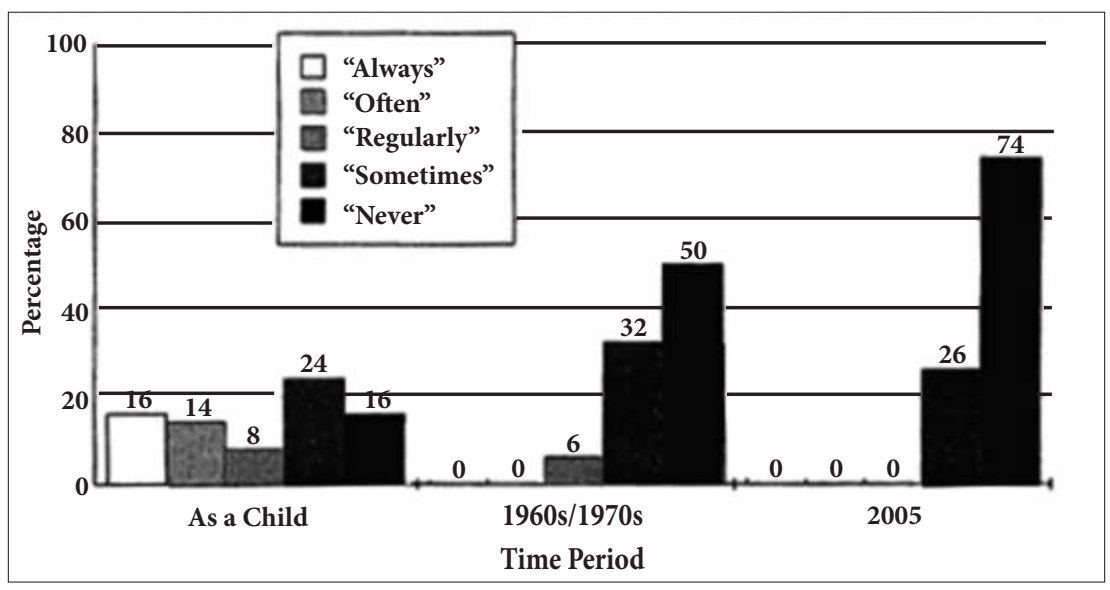

Figure 4 shows the percentages of speakers (total number: 52, a mix of Catholics and Lutherans) reporting the use of German at church when they were children, in the 1960 s, and in the early $21^{\text {st }}$ century. The distribution of answers for "always", "often", "regularly", "sometimes", and "never" shows a drastic decline in the use of German at church. During childhood, $16 \%$ of speakers reported to have always heard German at church, $14 \%$ heard it often, and $8 \%$ sometimes. These numbers 
dropped to $0 \%$ by the early $21^{\text {st }}$ century. Thus, it is safe to say that at the beginning of the $21^{\text {st }}$ century, German is not used in Texas churches any more.

\section{Conclusions}

German as a living language is dying out in Texas, whether it is the non-standard variety commonly known as Texas German, or whether it is the standard variety that was once widely used in Texas churches, schools, and newspapers. This paper has argued that many Catholic churches in Texas started making the switch to English already before World War I, while Lutheran churches made this switch during World War I, largely because of anti-German sentiments. For Lutherans, using German at church was closely tied to religious and cultural identity, which explains why it survived considerably longer in Lutheran churches. Other factors contributing to the decline of German in Texas include greater mobility, which allowed many Texas Germans to move to larger urban areas, where English was the majority language. At the same time, more and more English-only speaking Texans moved into areas that were once exclusively German speaking. Once these new arrivals joined local churches, their lack of understanding of German also contributed to more church services being offered in English. Finally, intermarriage also played a significant role. In mixed-language households, most parents decided to give up German in favor of English, the dominant language, which was more prestigious. All these factors contributed to the decline of German in Texas in general, and in formerly German-only speaking churches in particular.

\section{References}

Biesele, Rudolph: The History of the German Settlements in Texas, 1831-1861. Von Boeckmann-Jones: Austin 1930.

Blanton, Carlos K.: The strange career of bilingual education in Texas, 1836-1981. Texas A\&M Press: College Station 2004.

Boas, Hans C: "A Dialect in Search of its Place: The Use of Texas German in the Public Domain". In: Cravens, C./Zersen, D. (eds.): Transcontinental Encounters: Central Europe Meets the American Heartland. Concordia University Press: Austin 2005, pp. 78-102.

Boas, Hans C: "Best-practice Recommendations in Documentary Linguistics". Language Resources and Evaluation 40(2), 2006, pp. 153-174.

Boas, Hans C: The life and death of Texas German. Duke University Press: Durham 2009. 
Boas, Hans C./Pierce, Marc/Roesch, Karen/Halder, Guido/Weilbacher, Hunter: "The Texas German Dialect Archive: A Multimedia Resource for Research, Teaching, and Outreach". Journal of Germanic Linguistics 22, 2010, pp. 277-296.

Campbell, Randolph B: Gone to Texas. A History of the Lone Star State. Oxford University Press: Oxford 2003.

Eikel, Fred: New Braunfels Texas German. Johns Hopkins University: Baltimore 1954.

Gilbert, Glenn: Linguistic Atlas of Texas German. University of Texas Press: Austin 1972.

Grenoble, Lenore / Whaley, Lindsay: Endangered languages. Cambridge University Press: Cambridge 1998.

Heinen, Hubert: "German in Texas Schools, 1849-1939". Heritage of the Great Plains 15, 1983, pp. 11-20.

Jordan, Terry G.: German Seed in Texas Soil: Immigrant Farmers in NineteenthCentury Texas. University of Texas Press: Austin 1966.

Kloss, Heinz: „Die deutsche Schriftsprache bei den Amischen“. In: Auberger, Leopold/Kloss, Heinz/Rupp, Heinz (eds.): Deutsch als Muttersprache in Kanada: Berichte zur Gegenwartslage. Steiner: Wiesbaden 1977, pp. 97-98.

Nicolini, Markus: Deutsch in Texas. LIT Verlag: Münster 2004.

Salmons, Joe: "Issues in Texas German Language Maintenance and Shift". Monatshefte 75, 1983, pp. 187-196.

Salmons, Joe/Lucht, Felicia: "Standard German in Texas". In: Thornburg, Linda L./ Fuller, Janet M. (eds.): Studies in Contact Linguistics - Essays in Honor of Glenn G. Gilbert. Peter Lang: Frankfurt/New York 2006, pp. 165-186.

Wilson, Joseph: “The German Language in Central Texas Today”. Rice University Studies 63, 1977, pp. 47-58. 



\title{
Samantha Litty, Christine Evans and Joseph Salmons
}

(Madison)

\section{Gray zones: The fluidity of Wisconsin German language and identification*}

\begin{abstract}
Vor mehr als 150 Jahren wurden viele deutschsprachige Siedlungen in Wisconsin etabliert, in denen ein breites Spektrum von Dialekten, regionalen Umgangssprachen und auch standardnahen Varietäten gesprochen und geschrieben wurde. Im Laufe der Zeit wurden neue Generationen zwei- bzw. dreisprachig (Englisch, Deutsch, oft Plattdeutsch) und dann langsam monolingual englischsprachig. Damit verschwanden alte regionale Marker, oder zumindest verloren sie an Bedeutung. Anhand von literarischen Texten aus dem späten 19. Jahrhundert und Aufnahmen, die sich über eine Zeitspanne von den 1940er Jahren bis ins Jahr 2013 erstrecken, finden wir parallel zu diesen rein linguistischen Entwicklungen eine Dekonstruktion von alten sozialen und soziolinguistischen Gruppierungen und Identitäten. Die ältesten Daten deuten darauf hin, dass Sprecher mehrere deutlich unterschiedliche Varietäten des Deutschen beherrscht oder mindestens erkannt haben. Im 21. Jahrhundert sprechen unsere Consultants „nur Deutsch“, und sie verwenden eine Mischung von Dialektmerkmalen, die früher getrennt gehalten wurden. Identitäten und Identitätsgruppen sind verhandelbar und im ständigen Fluss, und wir argumentieren, dass Generationen von Deutschsprechern in Wisconsin sich auf relativ niedriger Ebene mit „Deutschtum" und verwandten Regionalgruppierungen identifiziert haben. Alte Grenzen wurden dekonstruiert, und diese Entwicklungen beeinflussen eine neue Wisconsin Identität, die noch im Aufbau steht.
\end{abstract}

Schlagworte: Sprachkontakt, Dialektkontakt, Sprache und Identität, Sprachwandel

Keywords: language contact, dialect contact, language and identity, language change

* The conference from which this paper grows gave us opportunities to sharpen our understanding of the setting we work with and we are deeply grateful to the organizers and participants for that. In addition to them, we thank the audiences at the Viadrina conference for discussions on this topic and comments on earlier versions of this manuscript, and Peter Rosenberg for extremely helpful feedback on a full draft of the paper. We are also grateful to Marit Ann Barkve, Ben Frey, Monica Macaulay, and Alyson Sewell for their constructive suggestions on a prior draft. An earlier version of the paper was presented at the 4th Workshop on Immigrant Languages in America (WILA), Reykjavík, Iceland in 2013, and feedback from that audience was crucial to the later development of the topic. 


\section{Introduction}

While immigrant language speech communities are often represented in terms of social and linguistic continuity, we argue here that over the course of more than a century and a half in Wisconsin, speakers of various kinds of 'German' have constantly and often dramatically reshaped both their speech and how they identify themselves. We focus on the intersection of these social and structural dynamics over time. Considering how German speakers in Wisconsin have and have not seen themselves over time allows us to capture likely motivations for some highly unusual linguistic developments.

The original speakers of German in 19th century Wisconsin brought repertoires of linguistic knowledge and practice that identified them regionally and socially in rich and complex ways. Like in German-speaking Europe, speech readily identified speakers as northern or southwestern and distinguished them as more or less educated, or at least more or less invested in Standard Language Ideology (Lippi Green 2011). Today's speakers continue to produce an array of known features, but in unexpected combinations and without the earlier social marking. Socially, we see these changes as a striking example of Brubaker's (2006) notion of 'groupness' and we use that to inform the structural linguistic changes in these communities.

Structurally, from early times, Northern or Rhineland speakers in Wisconsin pronounced gemacht as jemacht - realizing Standard German /g/ as [j] in onsets ( $g$-spirantization), while southwestern speakers produced fest as fescht, where /s/ is realized as []] before coda consonants, especially after $/ \mathrm{r} /$ (shibilization). Northerners and standard speakers had front rounded 'umlaut' vowels in schön and grün, while southern, less standard speakers unrounded to scheen and griin, /ø:/ and /y:/ versus /e:/ and /i:/ ([front vowel] unrounding). At the same time, more standard speakers used the genitive case, essentially absent from the dialects, while less standard speakers had no standard-like genitive and little or no command of the standard dative/accusative distinction, giving variation between die Mutter der Frau vs. die Frau ihre Mutter (among other constructions) and mit dem Vater vs. mit den/der Vater. In contemporary Wisconsin German varieties, we see instances of these very distinct regional and standard features being mixed that in a European context not only could not be found in the speech of a single person, but which are such strong regional markers that they are puzzling when first encountered.

Socially, discussion of German-American 'identity' typically focused as defining moments on the conflicts of the World War I and even World War II eras, on Nativism before that and on issues of 'ethnic revival' since the 1970s. In recent decades, the understanding of 'identity' in German-American communities has 
moved from a static to a constructivist one and the understanding of GermanAmerican varieties has moved from a static one to one anchored in notions of koinéization and contact-connected change. Here, we develop this general line of analysis, with direct connections to linguistic structure. We support this with evidence from eastern Wisconsin (especially Dodge County) from the 19th century to the present, as well as with indications of its social meaning. Specifically, for four datasets from different time periods, we look at structural features in terms of regional and standard character as introduced in the first paragraph above and examine what we can glean about the social interpretation of those features by speakers and listeners.

In this chapter, we first sketch Brubaker's model and expand it to structural linguistic issues $(\$ 1)$ and give background on the community, data sources and methods $(\$ 2)$. We then present evidence on linguistic features that Wisconsin speakers have had over the last several generations and on how they see themselves sociolinguistically. We begin with representations of German speech and identification in a 19th century play set in a fictitious Wisconsin city $(\$ 3)$. We follow with evidence from recordings made in the 1940s ( $\$ 4)$, recordings made in the 1960 s ( $\$ 5$ ) and finally contemporary recordings $(\$ 6)$. This arc of evidence shows steady patterns of change. Socially, this involves change from a focus on European regional identity to a more generalized 'German' identity to a specifically Wisconsin identity. Linguistically, this is paralleled by a loss of German dialects in these communities, shift to a far less regional but highly variable German and eventually to a regionally distinct variety of English. In the conclusion, $(\$ 7)$, we argue in particular for the multifaceted nature of socially constructed identities at each stage, one interconnected with language and dialect. Taking language and dialect as a rough correlate of identity, we focus here directly on linguistic variation.

\section{Brubaker's 'Groupness' and the connection to language structure}

As already suggested, looking at how German speakers in Wisconsin have, and have not, seen themselves over time allows us to capture likely motivations for some highly unusual linguistic developments. Brubaker's (2006) Ethnicity without Groups offers us a tool for understanding the social processes at hand, one that fits well with the linguistic processes we see in the history of German in Wisconsin. Brubaker calls for researchers to abandon previous notions of 'identity' and instead to take a fully dynamic approach to the topic. He argues that the constructivist position has become "complacent and clichéd" (2006, p. 3) and he pushes it farther, thinking in terms 
of unbounded, dynamic groups and "group-making" itself as a "project" (p. 13). He argues against using the notion of "identity" as an "analytical concept" (p. 61). ${ }^{1}$

Criticizing "the tendency to take bounded groups as fundamental units of analysis (and basic constituents of the social world)" (p. 2), he focuses on 'groupness', "a contextually fluctuating conceptual variable" (p. 11). While it seems widely accepted that both individuals and groups forge social groups, Brubaker stresses that memberships in groups not only changes, but the intensity of groupness can wax and wane.

Following Brubaker, our basic argument is that time and again in the history of German-speaking Wisconsin, group membership has been adjusted as individuals over their lifetimes and as generation after generation have negotiated a place socially and linguistically in an emerging Wisconsin society. Social scientists have long stressed that organizations and identities are not handed to us but rather that they are constructed and negotiated. For example, people, can cease to consider themselves 'Pomeranian' and begin to consider themselves 'German'. But more novel and interesting, to us at least, is Brubaker's insight that such memberships can be low-level or intense. While 'being German' (or 'Norwegian', 'Polish', 'Czech', etc.) in Wisconsin doesn't have much concrete impact on people's daily lives, they do often readily identify themselves as belonging to one group or the other, showing that this ancestry-based distinction has meaning for them. This groupness may not be particularly visible to non-group members, which leads us to argue that for our Wisconsin German speakers, groupness is usually the former, i.e. low-level, punctuated with moments of greater intensity.

Language plays a role in this as we accommodate to or differentiate ourselves from those around us. Changes in social affiliations are mirrored in and contribute to changes in linguistic behavior. People who came to the United States seeing themselves as 'Pomeranian', for example, became to some extent 'German' and 'Wisconsinites', and we can correlate these identifications with distinct linguistic patterns. One key, reflected in our title, is that these are never binary categories, but malleable and highly variable patterns, a set of gray zones.

We see these ever-changing features of structural linguistic variation and social identities most dramatically in instances where highly salient patterns from very different regions or from sharply different parts of the standard to non-standard continuum come together in the speech of individuals, where the social meaning of the structural features of language have clearly taken on new meanings and

1 We see this terminological/conceptual critique as badly needed within linguistics and closely related to Milroy's (1992) dismantling of the notion of 'prestige' in sociolinguistics. 
associations. We explore such examples from German and English here in the context of what is known about the speakers.

We argue that Germanness and its relatives (Low Germanness, notably) have at least almost always been distinctly low level for Wisconsinites. Previous research on diasporic German has assumed, often tacitly, a retention of dialects from the Old World and, with it, a group identity which our evidence suggests is largely fictional. For instance, Eichhoff states (1985, p. 234, emphasis added) that:

The dialects still extant in rural areas [of Wisconsin] preserve practically all the distinctive marks of the mother dialects in the German areas from which they originated. With the exception of the borrowing of lexical items from the English language, little if any development occurred.

These issues of course bear on identity as well as language and we present evidence below that paints a very different picture, one where much development has occurred both with regard to regional and social variation. In a certain sense, the dialects may not have changed so much as been lost in a shift to a general colloquial American German, showing dynamic development over time.

The mix of features we present here requires a different kind of account from those current in the literature on language and dialect contact. The Wisconsin German varieties we look at are not, for instance, typical of koinéization or new dialect formation where there are often 'compromise' features, widely shared features and features that are not socially or regionally marked. The mix is not typical of reallocation where existing features take on new meaning. It is also not indicative of a grammar gone wild, as some claim for terminal generation speakers. Instead we see that highly marked or salient regional and social features appear to spread. These features have lost their earlier social and regional significance, which we suspect may be traceable to a "loss of normativity" (drawing on a comment by Peter Rosenberg at the conference).

The constant, dramatic change in linguistic behavior from generation to generation supports Fuller's notion that ever-changing identity correlates with ever-changing linguistic behavior: "Language maintenance is not necessary for a distinct social group identity to persist, but the reverse is true: without a distinct group identity, a minority language will not be maintained" (2008, p. 15). With that context in mind, we turn now to the community and the data.

\section{Background on community and data}

We draw our data here from an area between Madison and Milwaukee, Wisconsin, namely Dodge County and an immediately adjoining area to the south in 
Jefferson County. Overall, this is one of the heaviest areas of German settlement in Wisconsin and, more importantly for present purposes, has perhaps the best and longest record of documentation of German varieties in Wisconsin, including dialects and standard-like varieties.

Over the last century and a half, eastern Wisconsin has seen a steady stream of varieties of German brought to the region by waves of immigrants, and those varieties have further developed here. In Dodge County, large-scale German immigration began in the 1840 s and continued into the early 20 th century. In many cases, immigrants and even their children and sometimes their grandchildren did not acquire English (Wilkerson / Salmons 2008, 2012, as well as Frey 2013 on areas just to the north), with $20-30 \%$ of the population in some communities still reporting being German monolingual in the 1910 U.S. Census, well over a half century after the major time of immigration. Such people often attended German-language schools and churches, participated in other German-speaking institutions and read local German-language newspapers and other publications.

While over a third of the state's population once spoke German of some sort, those varieties have steadily been lost during a shift to English. In many families, the first-generation immigrants were Low German-speaking, often specifically speakers of Pomeranian (East Low German), with varying knowledge of Standard German. Alongside Standard German often (but not only) learned in schools, heard in churches, read in newspaper, etc., many used a colloquial variety of German that we will call 'High German' here, characterized by a standard-like degree of the Second Consonant Shift, for instance, and readily intelligible to speakers of contemporary European German. They and later generations continued to use those languages as they acquired and began to use English. Today's generations are largely English monolingual. In short, over the course of 150 years, many families have gone from bilingual (Low German-High German) to trilingual (Low German-High German-English) to bilingual ([High] German-English) to monolingual (English). Along with this shift, the regional diversity people once understood as being part of German slips away. People even until today hear some range of regional variation, but that's really where it ends. The last generation of learners didn't acquire active command of most relevant regional and social variation. This change is being followed by the recent and still ongoing emergence of a distinct Wisconsin English (e.g. Salmons / Purnell 2010). As the languages used change, so too do the group identities of the speakers.

The earliest known recordings of German in the area were made in the late 1940 s by Lester W.J. 'Smoky' Seifert, with speakers born as early as the American Civil War (1861-1865). A second set of recordings was made by Jürgen Eichhoff 
in the late 1960s, with speakers typically born around the turn of the 20th century. The most recent recordings were made by graduate students at the University of Wisconsin-Madison in the spring of 2013. The real-time depth of our records is thus approaching 70 years, from 1947 until 2013, with speakers born over a yet longer time span, from the American Civil War through 1947. The oldest speakers were born into communities where German speakers were still immigrating, where, as just noted, institutional use of the language was widespread and strong, and where German monolingualism was still common. The youngest, in contrast, are the last Wisconsin-born speakers of German in their communities and grew up as the institutional use of the language was fading in most domains - though church services in German remained widespread into the 1970s and 1980s - and where even use of German in private domains had receded.

The core of our analysis draws on those audio recordings. We first present social evidence, then structural evidence. Our data come from three sets of recordings, all stored in the Max Kade Institute Sound Archives at the University of Wisconsin - Madison. We are able to examine the historical development of these communities thanks to the decades of recordings and we have access to a wide range of sociolinguistic and structural linguistic information thanks to those interviews.

Each dataset was produced under very different circumstances and for very different purposes. Seifert was documenting the German varieties of Wisconsin, recording both High German and dialect from many speakers, while Eichhoff was very specifically working to document Low German varieties. Contemporary work is much closer in spirit to Seifert's, with the aim of meeting Mattheier's challenge (1993, p. 50):

Eine Sprachinsel muss in ihrer Geschichtlichkeit ebenso erforscht werden, wie hinsichtlich ihre gegenwärtigen soziolinguistischen und linguistischen Strukturen, also nach Struktur und Status des Varietätenspektrums. (A language island must be investigated in its historicity just as in regard to its current sociolinguistic and linguistic structures, thus according to structure and status of the variety spectrum.)

Additionally, the interviewers differ. While he was a professor, Seifert was also a native speaker of Wisconsin German who knew many of the people interviewed and had grown up like most of them on a farm in bilingual Wisconsin. In the recordings he speaks a Wisconsin variety of English, a kind of High German that is surely familiar to his interlocutors and, where appropriate, a dialect of German widely used at the time in Dodge County. Eichhoff, also a professor, grew up in Northern Germany and speaks very standard, even professorial, German on the tapes, along with very fluent West Low German and fluent but accented English. 
The most recent interviews have been conducted by graduate students who are L2 speakers of German and who cannot generally speak Low German.

The technology and consultants' familiarity with the technology vary between the collections as well. Seifert made phonograph records using a SoundScriber machine with a microphone attached to the device, while Eichhoff produced reel-to-reel recordings. The newest recordings are made both directly onto computer hard drives and with portable digital recorders. It is unlikely that Seifert's speakers had ever seen a SoundScriber before the session and less likely that any had been recorded. This surely presented serious issues with the Observer's Paradox. In Eichhoff's day, we suspect that the technology was more familiar, even if people were not used to being recorded. Today, people are not only familiar with computers but also with recordings and the broadcasting of voice, e.g. voicemail and Skype, though even some of the most recent consultants do not have internet access at home and/or do not regularly use a computer.

At the same time, the interview conditions have changed in ways that will have likely influenced the behavior of the speakers. In the following analysis, it is important to keep in mind that socially sensitive variables were probably deployed by speakers differently when speaking to someone from their own community who spoke a German similar to theirs versus someone from Germany or someone speaking High German as an L2.

Our first challenge, especially with the historical recordings by Seifert and Eichhoff, is to establish what we can about which varieties of German (and English) the interviewees spoke and how well. To do that, we rely on direct and indirect evidence in the recordings, including the production of the speaker, the apparent comprehension of the speaker and reports of linguistic knowledge and usage. But let us begin with data from the time before sound recordings.

\section{19th century German Wisconsin literature}

We can start tracing social and structural features of Wisconsin German using literary sources from the 19th century and early 20th century. Local German plays, short stories and novels show the same variables under discussion in our recordings. Alfred Ira - a pen name for the minister and newspaper publisher Alfred Friedrich Grimm - wrote an extensive body of work that often includes (e.g. 1911) entire passages and dialogues written in three languages, Standard German, English and Pomeranian Low German, so that a reader needs to have reasonable command of all three to follow the story.

But this literature can reveal more about the knowledge expected from an audience in terms of regional and social variation, as we illustrate with structural 
linguistic features and language attitudes found in a play published in 1892 in Milwaukee by Julius Gugler (1848-1919), For Mayor Gottfried Buehler (despite the title, written in German). Gugler came to Milwaukee from Stuttgart at age 6. He writes Standard German but represents the speech of a diverse set of German-American characters. These include speakers of clearly Standard German, southwestern-accented colloquial German and what Gugler calls "ein gemischtes Deutsch" ('a mixed German'), German-American speech involving code switching. Gugler uses these different styles and dialects to depict characters of different social groups. As shown below, descriptions of the characters are not only about the personality of the characters, but also their speech patterns. This characterization implies something about the people who would have attended performances of this play or read it: Because of the specificity of each of these descriptions, it is clear that these varieties would have meant something to the audience and that this meta-linguistic discussion would have been meaningful to actors. We show this with three examples from the play. First, consider Gugler's description of the speech of a housemaid, Dörthe: ${ }^{2}$

Dörthe ist Repräsentantin der großen Rasse von Dienstmädchen, die ein gemischtes Deutsch, wie ich es angewandt, sprechen. Das Pommerisch-Mecklenburgische ist dabei vorherrschend. Man vermeide das Städtisch-Berlinische indessen soviel als möglich. (Dörthe is a representative of the great class of housemaids, who speak a mixed German, as I have applied it. Pomeranian-Mecklenburgish is predominant. City-Berlin dialect should be avoided as much as possible.)

We infer that, when this play was written in 1892, the German-speaking, theatergoing public in Milwaukee was not only familiar with the Low German, Standard High German and English presented in the play, but also that the structural patterns associated with dialects such as Pomeranian-Mecklenburgish and CityBerlinish signified something to the audience. To appreciate the play, then, the audience had to understand the social and regional values of these speech patterns. Take Dörthe's first soliloquy early in the play:

"Gott, was ist das heut vor ein excitement in dies Haus! Kein Augenblick nich Ruhe! (wirft sich auf das Sopha) Das up stairs und down stairs laufen! Und Miß Rosie thut mich onfahren, als ob ich heute nich meine Arbeit dhun thäte wie alle Dage! (gähnt und reckt sich) $\mathrm{Na}$, bei die bin ich nich so, obgleich man sich in dissen Land doch Nichts nicht jefallen zu lassen braucht und mich die Miß Maier in der Dritten Straße schon oft einen halben Dahler mehr die Woche versprochen hat, wenn ich zu sie kommen wollte!" ("God, what excitement there is in this house today! Not a moment of rest! (throws herself on the sofa)

2 Throughout, we retain Gugler's orthography. 
Running up and down the stairs! And Miss Rosie is on my case, as if I weren't doing my work today like every day! (yawns and stretches) Nah, I am not like that with her, although in this country one doesn't need to put up with anything and Miss Maier on Third Street has often promised me half a dollar more per week, if I wanted to come to her!")

When we look at Dörthe's speech, there are several markers to take note of. Most clearly, there are loan words and translations from English. Double negatives which appear are not found in Standard German, but are used dialectically and found in recordings from contemporary speakers in the area. Similarly, the use of tun as an auxiliary is common in regional colloquial speech, but not accepted in Standard German. Finally, the ge- prefix of Standard German appears as je-, which is an expected form in northern dialects. We conclude that these linguistic features evoked the expected social and regional associations for audience members, and thus contributed to the characterization of Dörthe. A second and quite distinct situation is that of a Low German speaker, whose speech is described this way:

Der Ticketpeddler Muß starken plattdeutschen Anklang haben. Zuviel mag indessen dem Verständniß seitens der Zuhörer nachtheilig sein. Wenn mein Versuch im Plattdeutschen von einem Schauspieler, dessen Muttersprache Niederdeutsch ist, verbessert werden kann oder soll, so hüte er sich nur davor, die Sache allzu echt zu machen. Der allgemeine Ton wohlgetroffen ist dem zu genauen Markiren des Einzelnen in der Sprache vorzuziehen. (The Ticketpeddler must have a strong Low German accent. However, overdoing it may be disadvantageous to the listener's comprehension. If my attempt at Low German can or should be improved by an actor who is a native speaker of Low German, he should beware not to make the speech too real. The successful general tone is preferable to the exact characterizations of the language.)

In fact, the language he uses is heavily Low German, but includes significant elements from High German, like at the end of this passage:

M-ja! Det mag't wohl sind, und ersten as ick noch jrün west, hefft ick't ooch so anseht, aberscht min Nochbar Jochen Snut söt tau mi: Dat's Allens was annerscht in Amerika; da möt man smart sind, hat hei segt! Wer d' meiste betohlt, de hat's; ob einer nu die Stimmen vor die Wahl kauft oder sie nachher kaufen dhut ...(M-yes! That may well be the case, and at first when I was still green, I also viewed it like that, but my neighbor Jochen Snut said to me: That's all different in America; there one needs to be smart, he said! Whoever pays the most, gets it; whether one buys the votes before the election or buys them after...)

The Low German here shows northeastern features, typical of Pomeranian, where the Ticketpeddler is said to be from, such as $g$-spirantization in complex syllable onsets, like in jrün for Standard German grün, more commonly realized in Low German as grön or gräun (Herrmann-Winter 1999). But it differs in details, such as the third person plural form of 'to be', given here twice as sind where the expected form would be sünd, [zYnt] (Russ 1989, p. 116, Lindow et al. 1998, p. 96). 
The speech of the Peddler shows the use of aberscht (Low German aberst), as well as annerscht (typically anners in Low German), both indicative of the shibilization found in southern and southwestern Germany. The key here is that the Peddler, a native speaker of Low German who otherwise shows no apparent southern or southwestern features, uses it. The area in Germany where this feature is common is nowhere close to Pomerania, as can be seen on the relevant Sprachatlas map (http://137.248.81.135/diwa/ECW.asp?ID1=261) or a simplified map (http://historyofgerman.net/dialect.html, by clicking 'fest/fescht'). One might suspect that Gugler simply missed his Low German target, though it is remarkable that this shibilization of $-r s t>-r s c h t$ is one of the very features we find in Eichhoff's recordings with Low German speakers in Wisconsin and which we still find today.

We can illustrate Gugler's representation of regionally-colored colloquial German (southwestern, in this case) and very standard German by this exchange between the young lawyer Gustav Dorn and mayoral candidate Gottfried Buehler:

BUEHLER: Deiner Ansicht nach bin ich also ein solch verwerflicher Candidat, daß nur der Umstand, daß wir verschwägert sind, Dich abgehalte hat, mich öffentlich zu blamire? (setzt sich wieder)

DORN: Da gehst Du nun zu weit, lieber Gottfried. Im Gegentheil, ich versuchte Dich vor einer Blamage zu retten. Ich schätze Deine Ehrbarkeit, und liebe Dich um Deiner ausgezeichneten Eigenschaften willen, aber um einer städtischen Verwaltung vorzustehen, dazu gehören hervorragende administrative Fähigkeiten, welche zu entwickeln Dein früheres Geschäft Dir wenig Gelegenheit gewährt hat.

BUEHLER: Well?

DORN: Der Hauptbeweggrund meiner Opposition aber lag in der Überzeugung, daß Dich lediglich der Ehrgeiz und die Langeweile treibt und nach einem Gespräch mit Marie bin ich zu dem Entschluß gekommen, ich thue ihr und vielleicht am Ende auch Dir einen Gefallen wenn ich handelte wie ich that, um die Familie vor einer immerhin möglichen Blamage zu behüten.

BUEHLER: In your opinion, then, I am such an objectionable candidate that only the fact that we are related by marriage prevented you from publically disgracing me? ${ }^{3}$ (seats himself again)

DORN: With that you go too far, dear Gottfried. On the contrary, I tried to save you from disgrace. I value your respectability and love you for your excellent character, but to preside over a municipal administration, that requires outstanding administrative abilities, which your earlier business allowed you little opportunity to develop.

3 In German-American varieties, blamieren often means 'to blame' but we read it in the present context as more likely still having the European German meaning. 
BUEHLER: Well?

DORN: The main reason for my opposition, however, lay in the belief that you were merely driven by ambition and boredom, and following a conversation with Marie I came to the conclusion that I would be doing her, and perhaps in the end you as well, a favor, if I acted as I did, in order to protect the family from still possible embarrassment.)

This conversation sounds very stiff and outdated to the contemporary ear, using complex syntax and structures, including the genitive case, which are not unprecedented, but are certainly not typical of conversational speech. Features of general colloquial American German, such as tun as an auxiliary, are notably absent, as are any clear dialectal features for Dorn. Dorn's highly Standard German would have been understood by the audience, and listeners would have recognized this speech as distinct from the non-Standard varieties of Dörthe and the Ticketpeddler. The conscious use and juxtaposition of Standard German, Low German and other German varieties, not to mention English, in literary works like Gugler's play highlight not only the widespread multilingualism of German speakers in 19th- and early 20th-century Wisconsin, but also the fact that particular features held clear regional and social associations.

\section{Evidence from 1940 s recordings}

In the 1940s, Seifert recorded German speakers in eastern Wisconsin, including at least 11 speakers from Dodge and neighboring areas of Jefferson County. These early recordings show basically no code-switching, and speakers appear to have full control of the two or more languages they speak. Some lexical borrowing occurs between varieties in all directions, mostly from English into Low German and German and occasionally from German into Low German. (See below for an example of this basic pattern from the later Eichhoff recordings.)

These recordings often give remarkable indications of the linguistic repertoires of the speakers. About half of the interviews recorded by Seifert are in his own native Oderbruch dialect (East Low German) with four labeled 'High German' and the others as 'Pomeranian.' The basic finding from listening to the recordings is that there is a remarkably clear distinction between standard High German with colloquial features and straightforward dialect. Beyond lexical borrowings and some regional character, mostly from prosodic patterns, the High German sounds impressionistically different from contemporary European German in ways that can be interpreted as reflecting contact with American English. For instance, American English-like approximate / $\mathrm{r}$ / occurs for some speakers in coda positions. While similar allophones exist in some varieties of German (like some Saxon dialects), those dialects are not found in this area to our knowledge. 
One simple example suffices here to show both regional and social aspects of variation in speech, from a Seifert interview recorded in 1947 with a male from Waterloo (Jefferson County, west of Watertown and just south of the Dodge County line). He was born in Wisconsin in 1864 and reports in the relevant U.S. Census data that he was a harness maker, likely retired at the time of the recording. Most of the recording consists of English-to-German translations and the speaker uses a colloquial German with an array of diverse regional features and many standardlike features. Consider this prompt and response, first transcribed in 'eye dialect' and then in Standard German orthography:

Seifert: 'The hens lay better in the spring than in the fall.'

RS: $\quad$ die Hihner, die legen besser im Frihjahr wie im Herbscht Die Hühner legen besser im Frühjahr als im Herbst.

The sentence shows patterns found throughout the speaker's interview, including the standard-like use of dative case twice $(\mathrm{im})$ and the non-standard and non-northern unrounding of front rounded vowels ([i:] for [y:] twice here, but unrounding of all front rounded vowels in the recording). He uses wie for the comparative particle rather than standard (and typically northern) als, and shows shibilization in Herbst. At the same time, in other parts of the recording the speaker spirantizes final /g/, e.g. [haitsəda:x] 'these days'. ${ }^{4}$

We do not have this speaker's linguistic biography - he appears in the 1900 to 1940 Census records and each time is shown as born in Wisconsin with Germanborn parents - and we do not know whether he spoke one or more dialects as well, but we know from the basic demographic history of the area that he lived in an area of heavy Low German influence where High German was widely known. Still, for a speaker born during the American Civil War, we find a set of distinctly nonnorthern features alongside some northern features and both distinctly standard and non-standard features.

\section{Evidence from the 1960 s recordings}

Eichhoff interviewed 7 speakers in this area, to our knowledge, 6 males and only one female. All of the speakers are interviewed in Low German. All speak Pomeranian, very fluently, with Eichhoff speaking English or Standard German to provide prompts for sentence translations and North Saxon Low German dur-

4 In word-final position (and often in syllable codas), German famously has 'final devoicing' or fortition, so that Tag 'day' ends with [k] for many speakers. Northern and some central varieties spirantize $/ \mathrm{g} /$, which together with fortition yields $[\mathrm{x}]$. 
ing free conversation. Because his goal is to record Low German, speakers use overwhelmingly Low German on the recordings, but indirect evidence shows that speakers had good comprehension of contemporary Standard German and American English.

To the first point, Eichhoff gives the speakers complicated sentences in High German and they all respond as easily as they do to his English as to his Low German prompts. In particular, he records most of the famous Wenker Sätze used in early German dialectology, including these:

- Im Winter fliegen die trockenen Blätter in der Luft herum.

'In the winter, the dry leaves fly around in the air.'

- Es hört gleich auf zu schneien, dann wird das Wetter wieder besser.

'It's going to stop snowing in a minute and then the weather will get better again.

- Tu Kohlen in den Ofen, damit die Milch bald an zu kochen fängt.

'Put coals in the stove, so that the milk will start to boil soon.'

- Der gute alte Mann ist mit dem Pferde durch das Eis gebrochen und in das kalte Wasser gefallen.

'The good old man broke through the ice with his horse and fell into the cold water.

In fact, only one speaker seems to have trouble with Eichhoff's Low German - as just noted Eichhoff is speaking North Low Saxon, while these people are speaking Pomeranian, varieties that are potentially not straightforwardly mutually intelligible - and another speaker seems to have a little trouble with his English. Yet no one seems to blink at his extremely standard Northern German. Speakers almost always do a linguistic biography at the end and they generally make explicit that they know German and Low German (also often called Platt). They all produced most numbers in German, not in Platt (with one speaker as an exception), and one asserts in answer to a direct question about what language he's using that they are in Platt not German. The consultants talk about using German and Platt, making clear that Deutsch does not include Low German for them. And they have High German loans in their Platt that are striking to the ear. One expressly uses a High German word and flags it as such: "de 'Rahm' seggt man, nich? Op Dütsch" (You say 'the cream', right? In German). This suggests that he could not recall the Platt and gave a German form instead, in fact a cognate with the Low German Rohm, though German has both Rahm and Sahne for this (with regional variation).

In addition to High German-to-Low German translations, Eichhoff does English-to-Low German translations, using sentences from a questionnaire Seifert had created. One speaker begins doing these in High German and self-corrects. Then, less than 30 seconds later, he starts doing them in High German and Eichhoff pushes him back into Low German. 


$\begin{array}{ll}\begin{array}{l}\text { Eichhoff: } \\ \text { Speaker: }\end{array} & \text { 'Light the fire.' } \\ & \text { O...mamach ma's Feuer an. } \\ \text { Eichhoff: } & \text { 'The wood is in the stove.' } \\ \text { Speaker: } & \text { Das Holz is im Oven. } \\ & \text { Das Holz ist im Ofen. } \\ \text { Eichhoff: } & \text { Nu Pla'dütsch. 'Light the fire.' } \\ \text { Speaker: } & \text { [Pause] Mach ma mach mach ma's Füer aa. } \\ & \text { Mach mal das Feuer an. } \\ \text { Eichhoff: } & \text { 'The wood is in the stove.' } \\ \text { Speaker: } & \text { Dat Holt is im Oven. } \\ & \text { Das Holz ist im Ofen. }\end{array}$

We conclude that these speakers understand complex sentences in Standard German easily and evidence suggests that they have decent command of it, based on production (one uses dative) and their self-reports. This is consistent with evidence from three Wisconsin communities in Schwartzkopff (1987: 148) that most speakers controlled the local dialect and standard-like German (see also Fuller 2008, p. 14).

\section{Evidence from contemporary recordings}

The first two authors of this paper - in part together with another fieldworker, Clinton Ford - recorded interviews with 28 speakers in this area, 15 of which are used here, 6 males and 9 females. The majority of speakers have ancestral ties to Pomerania, but consultants from one family mention ancestors from Germanspeaking Hungary and a few others do not know what parts of Europe their German-speaking ancestors emigrated from. That said, Sewell (2014) clearly shows, after several generations in Wisconsin, family histories become quite complex, with many individuals having ancestry from various regions, countries and language areas.

During the interviews, consultants completed several tasks, including free conversation. Consultants were asked to give information related to their ancestry as well as language usage throughout their lives so that we could create linguistic profiles. They completed a picture guided narration task using Frog, where are you? by Mercer Mayer and a translation task where they were asked to translate English sentences into the kind of German that was most natural to them. Consultants had varied responses as to where their families came from, how long they have been in Wisconsin and when they used German and with whom. Something many consultants had in common is that after childhood, they report far fewer opportunities for speaking German than previous generations had likely had, including, for example, 
marriages where one partner did not know German, and German was not taught to their children.

Contemporary speakers can comprehend the fairly standard European German of the graduate student interviewers, who sometimes needed to accommodate sound changes (notably [front vowel] unrounding) and word selection. Many speakers have contact with European German speakers and make regular references to the 'correctness' of European German. For them, Standard German plays a role in their assessment of their own speech. Through interactions with European relatives or acquaintances, for example, contemporary speakers of German in Wisconsin learn that 'gleichen' in the sense of 'to like' is not found in European German, but sometimes speakers assume that their own speech patterns differ more from European German than they actually do. As an example, one consultant observed:

B. We would say 'Guck mal', but I know that's not German.

The expression in question is, in fact, widespread in European German, albeit colloquial, and so illustrates how speakers of Wisconsin Heritage German recognize their German as different from that spoken in Europe. While these consultants are aware of some lexical and structural differences between their German and Standard German, there is typically little to no reference to regional dialects. Others suggest a classification of the German spoken in Wisconsin as a mix of German and English, in one instance calling it a 'slanguage'. Those who mention growing up with Low German input from Platt-speaking parents do not themselves produce more than a few words of Platt or phrases that they remember their parents/grandparents saying. For these speakers Low German is 'rough' or a less correct language, but they do not report it as having a clear relation to a particular region in Germany.

Today, Wisconsin German-English bilinguals speak varieties that show many features of colloquial German with regional coloring. If we use the classic defining characteristic of German dialects, the Second Sound Shift, their speech is in most cases standard-like, unlike the speech of virtually any of their ancestors. Beyond that, their language reflects varying mixtures of dialect features and features of Standard German as it is spoken in Germany today. Certain characteristics of Standard German morphology, such as - $t$ in third person singular verb forms and $g e$ - prefixes, are largely present, while other areas show pronounced variation. The syntactic and phonological patterns of the speakers show greater variation. A majority of the speakers produce both preterit (simple past) and periphrastic perfect forms, while only one (the youngest female, with Standard German training in school) produces inflected relative pronouns. The comparative wie is used by twice as many speakers as als, the latter consistent with Northern German usage and 
cognate with the Low German form as. The widespread use of tun as an auxiliary is strikingly non-standard - a feature long fought in standard language education but one found in most of the regions from where their families originally came.

For the most recent recordings, we compiled a list of features that we expected to find based on self-reported ancestral origin. We also list other features that struck us as unexpected or especially distinct. After the feature list was compiled, we listened to the recordings to determine what features each consultant produces. The table below lists these with examples. Some are found in several regions while others are specific to a single region in German-speaking Europe. A few are nonstandard, but regionally widespread. Bolded are features we expected to find based on region as well as a standard vs. non-standard distinction.

Table 1 Expected distribution of selected regional and non-standard features

\begin{tabular}{|c|c|c|c|c|c|}
\hline \multirow[t]{2}{*}{ Feature } & \multicolumn{5}{|c|}{ Region(s) where feature is expected } \\
\hline & Northern & Western & Central & Southern & $\begin{array}{l}\text { Supraregional } \\
\text { Non-Standard }\end{array}$ \\
\hline $\begin{array}{l}\text { front vowel unrounding } \\
\text { (Kühe > Kiehe) }\end{array}$ & $(\mathrm{X})^{5}$ & $\mathrm{X}$ & & $\mathrm{X}$ & \\
\hline $\begin{array}{l}\text { Shibilization } \\
\text { (erst > erscht) }\end{array}$ & & $\mathrm{X}$ & $\mathrm{X}$ & $\mathrm{X}$ & \\
\hline $\begin{array}{l}\text { g- j- } \\
\text { (gemacht }>\text { jemacht) }\end{array}$ & $\mathrm{X}$ & $\mathrm{X}$ & & & \\
\hline $\begin{array}{l}\text { initial } t \sim d \\
(\text { tun }>\text { dun })\end{array}$ & $\mathrm{X}$ & & & & \\
\hline $\begin{array}{l}\text { final } s \sim t \\
(\text { was }>\text { wat })\end{array}$ & $\mathrm{X}$ & & & & \\
\hline $\begin{array}{l}\text { final /k/ /x/ } \\
(\text { Weg > Wech) }\end{array}$ & $\mathrm{X}$ & $\mathrm{X}$ & $\mathrm{X}$ & & \\
\hline $\begin{array}{l}\text { apocope of final schwa } \\
\text { (ich gehe > geh') }\end{array}$ & $\mathrm{X}$ & $\mathrm{X}$ & & $\mathrm{X}$ & \\
\hline
\end{tabular}

5 According to Rosenberg (1986 and personal communication), unrounding was not unknown in the North through the beginning of the $20^{\text {th }}$ century. The forthcoming Norddeutscher Sprachatlas shows unrounding in the Berlin-Brandenburg regiolect as well as some varieties of Pomeranian. Thus, front vowel unrounding could have been a native feature of some Low German varieties brought to Wisconsin, though it is not common in northern varieties today. Likewise, shibilization is reported occasionally in some words, like Durscht and Wurscht. 


\begin{tabular}{|c|c|c|c|c|c|}
\hline \multirow[t]{2}{*}{ Feature } & \multicolumn{5}{|c|}{ Region(s) where feature is expected } \\
\hline & Northern & Western & Central & Southern & $\begin{array}{l}\text { Supraregional } \\
\text { Non-Standard }\end{array}$ \\
\hline $\begin{array}{l}\text { preterit } \\
(\text { ging }>\text { ist gegangen })\end{array}$ & $\mathrm{X}$ & & & & \\
\hline $\begin{array}{l}\text { als } \sim \text { wie comparative } \\
\text { (kleiner als }>\text { kleiner wie) }\end{array}$ & & & $\mathrm{X}$ & $\mathrm{X}$ & $\mathrm{X}$ \\
\hline $\begin{array}{l}\text { tun auxiliary } \\
(\text { arbeitet } \sim \text { tut arbeiten) }\end{array}$ & & & & & $\mathrm{X}$ \\
\hline $\begin{array}{l}\text { inflected relative } \\
\text { pronouns } \sim \\
\text { uninflected particles } \\
(\text { das } \sim \text { wo })\end{array}$ & & & & & $\mathrm{X}$ \\
\hline
\end{tabular}

The following patterns emerged from a case study of a mother and her two daughters, whose family originally came from Northeastern Germany. Linda, the mother, 101 years old at the time of interview, exhibits expected features as well as unexpected features common in Northern and Northwestern Germany. Susan, 69, exhibits expected features as well as unexpected features common in Northern, Northwestern, Southwestern and Southern Germany. Brenda, 66, exhibits expected features as well as unexpected features common in Northern, Northwestern and Southwestern Germany. While the mother and daughters each exhibit varying individual features, the following common set in Table 2 was remarkable to us.

Table 2 Categorization of selected linguistic features in contemporary Wisconsin data

\begin{tabular}{|llll|}
\hline $\begin{array}{l}\text { Colloquial features } \\
\text { from the Northeast } \\
\text { (Expected) }\end{array}$ & $\begin{array}{l}\text { Typically non-northern } \\
\text { features (Unexpected) }\end{array}$ & $\begin{array}{l}\text { Standard-like } \\
\text { Features }\end{array}$ & $\begin{array}{l}\text { Non-Standard-like, } \\
\text { Non-Regional } \\
\text { forms }\end{array}$ \\
\hline $\mathbf{k}>\mathbf{x}$ & wie for als & Tier not Dier & relative particles \\
ge- $\sim$ je- & front vowel unrounding & was not wat & \\
& Shibilization & $\begin{array}{l}\text { potential } \\
\text { avoidance of tun }\end{array}$ \\
\hline
\end{tabular}

The coupling of dialect and standard traits throughout the data and, more significantly, within individual speakers indicates that the original social and pragmatic meanings associated with the traits have faded in this context. Furthermore, the 
features present reflect a mixture of regional dialects that would not come into contact in Europe.

In addition to the original 15 German-speaking consultants from whom we draw linguistic evidence, several speakers from the area were interviewed who do not speak German, but grew up in a majority German-speaking community or come from families in which parents and grandparents spoke German. Often it is these consultants who emphasize traditions of the past and who verbalize their attachment to being 'German'. For consultants who grew up with German in the home, being 'German' was just something that happened. In these cases, the speakers place less importance on maintaining overtly 'German' traditions and rituals, and their 'Germanness' stems from the fact that they happened to have German parents and learn the language at home. These comments suggest that the consultants maintain only a low-level identification with German. At the same time, during interviews most speakers show great interest in their heritage, modern Germany and 'correct' German. Through the linguistic behavior and personal observations of these speakers, we see that identification with the categories of 'German', 'Low German' and 'American' has shown and continues to show remarkable flexibility in these communities.

\section{Conclusions}

In the earliest (and least reliable) dataset, 19th century literary representations, we see a relatively clean separation of forms associated with particular varieties: Characters represented by Gugler as being from Pomerania speak, from the available evidence, unremarkable Pomeranian, save for the curious presence of shibilization. Gugler represents speakers of colloquial southwestern German, presumably his own native variety, and it too is unremarkable. The distinctively German-American characters have lexical borrowings, code-switching, and influence from English very close to what contemporary speakers have, like the ubiquitous discourse markers such as well. The most standard German passages would count as stiff and archaic in Europe today.

A broad pattern of evidence strongly suggests that in the late 19th century many speakers had native-like command of multiple, very distinct kinds of 'German. We have presented evidence from literature here, but this is thoroughly consistent with evidence from letters and various metalinguistic comments in newspapers and elsewhere. Whatever the speakers' active command, the variants were understood and had social value. For example, Low German features used in High German signaled something about a speaker's regional background in Europe and educational/social background. And the use of English within 
German discourse signaled something about education and social status. Use of heavily formal standard German, more or less per definitio, signals something both about educational/social status and language attitudes.

Seifert recorded numerous speakers using different varieties, while Eichhoff's speakers use Low German but show good comprehension of and indications of production skills in High German. In our fieldwork, no speakers have been able to complete the picture narration in more than one variety, though Lucht was able to record some speakers doing the narration in Low German (2007). ${ }^{6}$ As the range of dialects and languages has contracted, the stylistic register has also contracted, including integration of regional features from dramatically different parts of Europe into the speech of most individuals. This is not, we argue, typical sociolinguistic reallocation, and while it shows characteristics of partial koiné formation, it differs in important ways.

We have seen an almost complete shift from Low German varieties, especially Pomeranian and other East Low German dialects/languages, to a variety that has the defining characteristics of High German, e.g. in terms of the Second Consonant Shift. Such contemporary speakers show traces of their Platt-speaking heritage and at the same time features that are emphatically not of East Low German provenance. For instance, these speakers often use the distinctively northern pattern of realizing $/ \mathrm{g} / \mathrm{as} / \mathrm{j} /$, so that gegangen is pronounced jejangen. These forms preserve the features of most of their ancestors. But those same speakers often produce strikingly southern patterns like pronouncing German wir as mir/mer and using the western and especially southwestern shibilization pattern -rst- > -rscht. Once regionally identifiable, these features are now simply 'German'.

While the inventory of dialectal features we have investigated here remains amazingly consistent across more than 120 years, the situation has not been static. From Gugler's literary representations through Seifert's and Eichhoff's audio recordings from the 20th century and current fieldwork, we find speakers producing onset $/ \mathrm{g} / \mathrm{as} / \mathrm{g} /$ or $/ \mathrm{j} /$, producing final $/ \mathrm{g} /$ as $/ \mathrm{x} /$, producing third person singular present verbs with or without final $-t$, using tun as an auxiliary, and so on. What has changed is how and by whom they are used.

Our evidence shows the dynamic nature of linguistic patterns and social 'identification'. This constant reconfiguring of 'identification' fits Brubaker's notion of

6 While Low German has receded or perhaps disappeared in this area and some others, e.g. to the north in Sheboygan County, it is still spoken especially in central Wisconsin. See, for instance, Jacob 2002. 
groupness as flexible and low-level. The dynamic nature of what languages/dialects people spoke or speak parallels this. Earlier markers of particular regional 'identity' or connections with 'Standard German' have been bleached of social meaning. Gugler's regional and social stereotypes are no longer recognized. The range of command of dialects/languages found by Seifert and Eichhoff is gone. Our consultants speak 'German', not 'German' and 'Pomeranian' in Dodge County. The use of previously salient regional features like je-, -rscht, or front vowel unrounding are what now exists as 'German' in these communities. Remarkably, receptive capability remains strong, so that we can speak Standard German with them and many of them speak with European Germans.

We conclude that there has been steady change over time and now a kind of deconstruction of social and linguistic borders is taking place in Wisconsin. In correspondence about this paper, Rosenberg makes the important comment that vital language islands are complete language systems with wide ranges of styles and registers, and compromises or losses thereof are a sign of the retreat of the language island (personal communication). Though we leave it to future research to more fully address register compression the Wisconsin German setting, the above data show a steady dissolution of former distinctions as Low German and southern/southwestern features become 'just German' and Standard and dramatically non-standard features become unmarked, as well. This is highly consistent with Fuller's view of identification as motivation for maintaining language rather than vice versa. Most of the last German speakers demonstrate only low-level identification with 'Wisconsin German', and non-speakers now talk much more about a 'German identity' than speakers do. A new Wisconsin identity is recent and its formation is still ongoing. There may be construction of new boundaries, but it is regional rather than immigrant and further patterns will be seen in English, not German.

\section{References}

Brubaker, Rogers: Ethnicity without Groups. Harvard University Press: Cambridge 2006.

Frey, Benjamin: Toward a General Theory of Language Shift: A Case Study in Wisconsin German and North Carolina Cherokee. (doctoral thesis) University of Wisconsin - Madison: Madison 2013.

Fuller, Janet M.: "Language and Identity in the German Diaspora". In Schulze, Mathias et al. (eds.): German Diasporic Experiences. Wilfried Laurier: Waterloo, Ontario 2008, pp. 3-19. 
Goss, Emily L. / Salmons, Joseph C.: "The Evolution of Bilingual Discourse Marking: Modal particles and English markers in 19th century German-American dialects". International Journal of Bilingualism 4, 2000, pp. 469-494.

Gugler, Julius: Dramatisches. Selbstverlag: Milwaukee 1892. http://csumc.wisc. edu/mki/LitProject/lit_project.html.

Herrmann-Winter, Renate: Plattdeutsch-hochdeutsches Wörterbuch. Hinstorff: Rostock 1999.

Ira, Alfred: Aus der alten Kaffeemühle. Antigo Publishing: Antigo 1911.

Jacob, Alexandra: Niederdeutsch im mittleren Westen der USA: Auswanderungsgeschichte, Sprache, Assimilation. Verlag für Regionalgeschichte: Bielefeld 2002.

Lindow, Wolfgang et al.: Niederdeutsche Grammatik. Verlag Schuster: Leer 1998.

Lippi Green, Rosina: English with an Accent: Language, Ideology and Discrimination in the United States. Second edition. Routledge: London 2011.

Litty, Samantha: Time for /t/: VOT variation in three southern Wisconsin counties. (manuscript).

Lucht, Felecia: Language Variation in a German-American Community: A diachronic study of the spectrum of language use in Lebanon, Wisconsin. (doctoral thesis) University of Wisconsin - Madison: Madison 2007.

Mattheier, Klaus J.: "Sprachinselsoziolinguistik: Beobachtungen und Überlegungen an deutschsprachigen Sprachinseln“. In Salmons, Joseph (ed.): The German Language in America, 1683-1991. Max Kade Institute: Madison 1993, pp. 38-61.

Milroy, James: "Social network and prestige arguments in sociolinguistics". In Bolton, K. / Kwok, H.: Sociolinguistics today: international perspectives. Routledge: London 1992, pp. 146-162.

Nützel, Daniel / Salmons, Joseph: "Structural Stability and Change in Language Contact: Evidence from American German". Language and Linguistics Compass 5, 2011, pp. 705-717.

Rose, Mary Aleene: Language, Place and Identity in Later Life. (doctoral thesis) Stanford University: Palo Alto 2006.

Rosenberg, Peter: Der Berliner Dialekt und seine Folgen für die Schüler. Geschichte und Gegenwart der Stadtsprache Berlins sowie eine empirische Untersuchung $z u$ den Schulproblemen dialektsprechender Schüler. (dissertation). Niemeyer: Tübingen 1986.

Salmons, Joseph / Purnell, Thomas: "Language Contact and the development of American English". In Hickey, Raymond (ed.): The Handbook of Language Contact. Blackwell: Oxford 2010, pp. 454-477. 
Schirmunski, Viktor M.: Deutsche Mundartforschung: Vergleichende Laut- und Formenlehre der deutschen Mundarten. Akademie Verlag: Berlin 1962. New edition by Naiditsch, Larissa with Wiesinger, Peter (eds.), translated by Fleischer, Wolfgang. Peter Lang: Frankfurt 2010.

Schwartzkopff, Christa: Deutsch als Muttersprache in den Vereinigten Staaten. Teil I: German Americans: Die sprachliche Assimilation der Deutschen in Wisconsin. Steiner: Stuttgart 1987.

Sewell, Alyson: A socio-historical study of heritage languages: Accounting for variation among Wisconsin German varieties. Second International Conference on Heritage/Community Languages. UCLA. March, 7-8, 2014.

Wilkerson, Miranda / Salmons, Joseph: “Good old immigrants of yesteryear' who didn't learn English: Germans in Wisconsin”. American Speech 83(3), 2008, pp. 259-283.

Wilkerson, Miranda / Salmons, Joseph: "Linguistic Marginalities: Becoming American without Learning English". Journal of Transnational American Studies 4(2), 2012, acgcc_jtas_7115, from http://www.escholarship.org/uc/ item/5vn092kk. 



\section{Language borders and discourse}





\author{
Konstanze Jungbluth \\ (Frankfurt/Oder)
}

\title{
Crossing the Border, Closing the Gap: Otherness in Language Use
}

La proximité de l'autre en tant qu'autre est une énigme.

Emmanuelle Lévinas

\begin{abstract}
Identität spiegelt sich im Konzept des Anderen, Alter, wider. Ich bzw. wir stehen dem $D u$ und ihr gegenüber. Der Andere ist einerseits so wie ich selbst ('sameness', Raible 1998), gleichzeitig aber anders als ich ('otherness'; Schlieben-Lange 1998). Die Spannung zwischen beiden Dimensionen feuert die Forschung zu Alter an. Sprachgebrauch ist an den Anderen adressiert. Meine These ist, dass das dialogische Prinzip allem Sprachgebrauch inne wohnt und ihn zu allererst auszulösen vermag. Damit begründe ich die hierarchische Voranstellung der Alterität vor den anderen Universalien der Kreativität und Semantizität, die gefolgt von der Historizität und der Exteriorität Sprache bestimmen.
\end{abstract}

Soziale Interaktion ist in der dyadischen Konzeptualisierung von Sprache aufgehoben (Jungbluth 2005). Der andere ist ein Alius, so lange er außerhalb ('outside') steht und nicht zum Alter im Gespräch wird. So ist es in face-to-face Gesprächen nicht üblich, dass eine Grenze zwischen den Gesprächsteilnehmern gezogen wird. Vielmehr wird in der Interaktion ein ungeteilter Raum innerhalb ('inside') geschaffen, der das hier begründet und ein gemeinsames Handeln, sprachlich und in Taten, für das Erreichen gemeinsamer Ziele erst möglich macht.

Das Konzept der Alterität ist nicht beschränkt auf Paare oder kleine (Gesprächs-)Gruppen, sondern kann auch auf große soziale Gruppen, darunter auch ethnische Gruppen angewandt werden. Diskursgemeinschaften, aber auch ganze Sprechergemeinschaften teilen ein kollektives Gedächtnis. Auf dieser Ebene ist der Kontrast zwischen uns ('we') und den anderen ('they', e.g. the others) über Unterschiede beispielsweise zwischen Religionen, Gesetzgebungen, politischen und sozialen Institutionen (einschließlich kultureller Praktiken in den jeweiligen Diskursdomänen), der jeweiligen Geschichte, Literatur, Kunst und Sprache bestimmt. Im Kontext der Diskurse auf gesellschaftlicher Ebene können wir aber auch an Stelle der Differenzen die Gemeinsamkeiten in den Vordergrund stellen. Alterität setzt immer auch Gleichsein voraus, Identität ist ein anderes Wort dafür.

Schlagworte: Pragmatik, Sprachgebrauch, Alterität, Ethnizität, Gesprächsdyade, außerhalb, innerhalb

Keywords: pragmatics, language use, alterity, ethnicity, dyad of conversation, outside, inside 


\section{Introduction}

The concept of otherness may be investigated in the context of small groups, pairs engaged in face-to-face communication, or at the level of large social groups, such as those defined by ethnicity. Communities of discourse or whole language communities share a collective memory. In these contexts, the opposition between us and the others is constructed upon differences of religion, law, political and social institutions (including behavioral conventions in the respective domains of discourse), history, literature, art and language to mention just a few. In the context of conversations within society at large, instead of focusing what is different, we may as well underscore what we have in common.

In this paper, my focus on the one hand is on the general, ahistorical level of language use as such, regardless of the historical language spoken (e.g. English, German, Spanish etc.). Here, alterity represents, as I claim, the first of five universals. Furthermore, I shall develop the activities of speakers and hearers reciprocally when they speak to one another. The hEARing of the listener is as important as is the utterance of the speaker. When one of them fails to go on, people fall silent. Responsivity is fundamental and mirrors alterity at the level of dialogue.

I start with the general view, discussing alterity as the double-faced first universal of language. In the second part, I develop the difference between the other as Alius and the other as Alter. Furthermore, sameness and otherness are unpacked. In the third part, language use seen as acts of identity which are considered to show alterity in some sense are presented, and the application of the respective terminology is discussed. I claim that acts of alterity are just the other side of all acts of identity, as language use is always directed towards the other. Finally, I will integrate the dynamics of the conversational work into the triangle of Bühler by sketching out the activities of the speaker and hearer, who are both simultaneously making references to the world.

\section{Alterity: the double-faced $1^{\text {st }}$ universal of language}

Otherness in language use puts into focus alterity as one of the five universals alongside creativity, semanticity, historicity and exteriority (Coseriu 1975), which define language as such. Later on, a hierarchy between the five was established, where the genuinely ahistoric aspects of alterity, creativity and semanticity are taken as primordial, whereas historicity and exteriority are considered as derivational (Schlieben-Lange 1998, 44). Based on research of language use in interaction in a 
broad understanding, where language use forms only one part of the ongoing communication, I claim that alterity is the very first of the five universals ${ }^{1}$.

Alterity is a condition for language use, as any speech act is directed from one subject towards another (cf. Coseriu 1975, 154; see Benveniste 1946/66, 230²). In other words, speaking and listening happen between EGO and ALTER, on the first level, whereas creativity on one side refers to the self ${ }^{3}$, and semanticity, on the other, to the world. It is not by chance that the edges of the underlying triangle formed by the speaker, her hearer and the world determine the signs themselves, namely the linguistic signs (see the famous model of the organon, Bühler 1934). People have to speak "as the others", which refers to historicity of language as the fourth universal, and "towards the other/s" which covers the expression perceivable by others. Its substance is the materiality of language use being crucial for exteriority of language. Examples of it may be stored in form of data, and compiled to smaller or bigger corpora, thus turning the ongoing flow of language use into érgon (see below), apt for linguistic purposes.

Figure 1: Five universals of language at three levels

\begin{tabular}{|c|c|c|c|c|}
\hline & \multicolumn{2}{|c|}{ 1. EGO \& ALTER Alterity } \\
\hline & Creativity & & Semanticity & WORLD \\
\hline & as the others & double faced & towards the other/s & \\
\hline & Historicity & & Exteriority & \\
\hline
\end{tabular}

(cf. Schlieben-Lange 1998, p. 44)

1 Blank (1997) claims that semanticity has to be considered as superior with regard to the others. See conclusions at the end of this paper.

2 It is in using language that a human being constitutes [her-/]himself as a subject, because language alone founds in reality - in its reality which is the one of being- the concept of ego (Benveniste1956/1966, p. 259; my translation).

Language is only possible when every speaker positions her-/himself as a subject [...in her/his discourse]. In doing so, I position another person, exterior to myself, echoing myself by calling her/him you and [s] he calls me you. (Benveniste1956/1966, p. 260, my translation; cf. Jungbluth 2005, p. 22).

3 In social psychology, the difference between EGO and self may be exemplified by the following citation: «One of the most noteworthy features of Mead's account of the significant symbol is that it assumes that anticipatory experiences are fundamental to the development of language. We have the ability [to] place ourselves in the positions of others-that is, to anticipate their responses-with regard to our linguistic gestures. This ability is also crucial for the development of the self and self-consciousness. For Mead, as for Hegel, the self is fundamentally social and cognitive. It is to be distinguished from the personality, which has non-cognitive dimensions» (cf 2.3.; Mead 1980, Aboulafia 2012). 
In this contribution, I will give preference to the first and second levels. Concerning the third level, I refer the readers interested in these topics to my dissertation on Catalan (Jungbluth 1996). There, historicity of language is unfolded using the example of the continuity of the use of Catalan in spoken, and - even more importantly with regard to those times - written language. Products of orality and literacy taken together make exteriority of language manifest. The so called libri di famiglia, a European discourse tradition performed since the golden times of Florence, are the research object of this monograph. They confirm the unbroken use of this 'small' Romance Language during the so-called decadència by providing evidence of the continuity of Catalan writing since the times of Ramon Llull (1232-1316) until today (see 1.2.). Different from that approach, this paper places the focus on alterity, creativity and semanticitiy, while the other two universals will be left to be mentioned in passing (see 2. \& 3.).

\subsection{Alterity and Creativity}

Focusing on the double-faced nature of alterity, creativity looks at the actor of language use and her way of expressing herself $f^{4}$. Every utterance is unique, and even the same speaker will not be able to reproduce it in the same way again. The creativity of language use is not limited to experts - as for example authors of the various literary genres - as some authors believe, but is an important aspect of language use of everyone who speaks and maybe writes. Following Humboldt, language is enérgei $a^{5}$, a creative activity which is done due to dýnamis, a competence in the sense of Aristoteles, and may only be fossilized to become érgon by linguists (Albrecht/Lüdtke/Thun 1988; Lehmann 1988). Whereas alterity strengthens the uniform use of a certain historical language, creativity ensures its difference, which may end up creating a variety in its own right. In the aspect of creativity, the freedom of language is particularly tangible. This nature of its object of research determines the way in which linguists may draw their conclusions:

4 Derrida's use of différance instead of différence, may be used as an example of this freedom, showing the creative use of language to express a particular, unique idea. See 1.3.

5 „Die Sprache in ihrem wirklichen Wesen aufgefasst, ist etwas beständig und in jedem Augenblick Vorübergehendes ... sie selbst ist kein WERK (ÉRGON), sondern eine TÄTIGKEIT (ENÉRGEIA).... sie ist nämlich die sich ewig wiederholende Arbeit des Geistes, den artikulierten Laut zum Ausdruck des Gedankens fähig zu machen. Unmittelbar und streng genommen ist dies die Definition des jedesmaligen Sprechens; aber im wahren und wesentlichen Sinn kann man nur die Totalität des Sprechens als die Sprache ansehen." (Humboldt 1827-29/1963, pp. 196-97; emphasize added). 
In one sense linguistics does not have to "become" an exact science, as it is already one. And in another sense it does not become one as the nature of its object does not permit it. Linguistics must give up the irrational intention to look for causality in the space of freedom. ${ }^{6}$ (Coseriu 1974, p. 205, my translation).

Following Humboldt (1827-29/1963), the two forces which the language user experiences are contradictory:

[..] the normativity of the language exercises pressure on him, whereas the principle of freedom roots in his retroactive reaction ${ }^{7}$ (Humboldt 1963, p. 228).

A good deal of this normativity is exerted by semanticity, the other universal and the topic of our next section. People usually communicate in order to achieve understanding by using the same language ${ }^{8}$, which identifies them as members of one and the same language community.

\subsection{Alterity and semanticity}

There is no doubt that speaking, and language use in general, inherently express meaning. Derived from the aforementioned competence, the activity of language use performed between the speaker (or author) and her listener (or reader) may be divided in the following three sub-activities: First, we know how to refer to the world (referentiality). It goes without saying that one has to know the things «Kenntnis der Sachen» (Kabatek/Murguía/Coseriu 1997) in order to refer to them properly. After having learned how to subsume the objects and states of affairs in form of linguistic signs, such as words in our first language, we can apply this practice to all of them. Another universally valid aspect of language use is the possibility to talk about langue itself (reflexivity). Finally, without an intention underlying our talk, we keep silent. The interest to change the world by speaking to the other gives meaning as an overall aspect of the ongoing social activity (finality).

Focusing on language use of a certain historical language, e.g. German or English, meaning refers to the systematic and normal use of words as part of its lexicon, and of their combination as part of its grammar. This way of speaking

6 «In einem Sinne also braucht die Sprachwissenschaft nicht zu einer exakten Wissenschaft „werden“, da sie es bereits ist. Und in einem anderen Sinne kann sie es nicht werden, weil die Natur ihres Gegenstandes es ihr verbietet. Die Sprachwissenschaft muss auf die irrationale Absicht verzichten, im Bereich der Freiheit Kausalgesetze aufstellen zu wollen.»

7 in dem auf ihn ausgeübten Einfluss liegt die Gesetzmässigkeit der Sprache, in der aus ihm kommenden Rückwirkung das Princip ihrer Freiheit.

8 Sometimes they use more than one language, and this bi/multilingual usage characterizes their linguistic community. 
represents the language-specific form of expressing references to the respective surrounding world. The practice forms part of the tradition which is passed from generation to generation, thus giving continuity to the language and maintaining its use. Of course, concrete meaning is only achieved when materializing the linguistic sign through its actualization in a certain discourse $e^{9}$. In doing so, the reference to a concrete part of the world takes place, and the participants of conversation can judge whether or not it makes sense in the ongoing context. The point of reference is the conventionalized way to use the language, its érgon products being lexicon and grammar, aiming to speak as the other/s.

\subsection{Double faced alterity \& its two relations [as the others : for the others]}

It is this tension between speaking as the others and speaking for the others which determines the use of language in discourse. We experience that our understanding is vague, and that the identities involved in conversation remain incommensurable (Schütze 1980). At the moment of discourse itself, we put these findings aside and trust the symbols and gestures, though the ongoing negotiations of the meaning of our utterances remain incomplete. We have in mind that the pronounced signs are less than what was actually meant by the speaker, and less than what was understood by her hearer, and even not the same when several hearer/s are involved. Every subject has to "fill in" the utterance - to suppléer in Derrida's terms (1976, p. 323) - or has to insert something extra in order to achieve full understanding. The différance $e^{10}$ [sic!] explained by Derrida refers to the several - in principle endless - meanings which every utterance, every use in context, every reading or listening produces at the base of the apparently same signifiant(s). The not-understanding, which is one of the sources of the difference, forms part of every understanding:

When a word is uttered, nobody thinks in that moment exactly the same as the other and the difference, even the very small one goes on trembling through the language as a whole similar to a drop of water with its circle. Every understanding is always a not-understanding,

9 I do not discuss here the aspect of discourse traditions which themselves represent certain meanings of the discourses they gather, e.g. the above-mentioned libri di famiglia, accounting documents, novels, poems etc. (see Weiand 1993, Wilhelm 2001, SchliebenLange 1983, Jungbluth 1996).

10 Cf. French différence. Although the pronunciation of the two is the same, the 'significats' are not. 
a truth which may be readily used in every-day life too, all convergence in thoughts and sentiments involve simultaneously some divergence ${ }^{11}$ (Humboldt 1827-29/ 1963, p. 227).

The balancing act between talking as the others and for the others has to be mastered by any language user involved in a dialogue. The creative use of language in order to express my own stance by constantly performing acts of identity (Le Page / Tabouret-Keller 1985) has to comply with the norms of the language/s shared by my interlocutors, by you. The performance is directed towards the other participant/s of conversation. You, my partner/s in dialogue, have to be able to recognize the acts as such in order to achieve a reciprocal understanding.

\section{Alterity: closing the gap}

Who is/are this/these strange other/s? Is the other someone as oneself or someone different? Does it matter whether the other is someone you talk to or someone else? Is there a difference between the involved second person and the third person, not involved in conversation?

\subsection{Sameness versus Otherness}

On one hand, speaking like the others means using the same language spoken by your family or by your ancestors, by the language community you belong to. The sameness is rooted in historicity, as the historical language refers to the way its users embedded in their environment have acquired the knowledge and routines to speak it (and maybe were taught to write it) at a certain moment in time. The opposition of sameness is otherness.

That, what actually binds us with others and serves as a unifying bond of a social or group identity, is shared living experience ${ }^{12}[. .$.$] otherness and sameness are dialectical concepts$ presupposing one another. [...] To this corresponds the fact that, contrary to mathematics, in real life «being other or «being different implies at the same time having much in common> . [...] To look at identity in the social sphere means foregrounding sameness, whereas alterity emphasizes otherness (Raible 1998, pp. 16-21).

11 „Keiner denkt bei dem Wort gerade und genau das, was der andere, und die noch so kleine Verschiedenheit zittert, [wie ein Kreis im Wasser], durch die ganze Sprache fort. Alles Verstehen ist daher immer zugleich ein Nicht-Verstehen, eine Wahrheit, die man auch im praktischen Leben trefflich benutzen kann, alle Uebereinstimmung in Gedanken und Gefühlen zugleich ein Auseinandergehen" (Humboldt 1963, p. 227).

12 See shared cultural memory 'kulturelles Gedächtnis' (Jan Assmann 1992; Aleida Assmann 1999). 
All acoustic or written signs of some language variety are directed towards the hearer/reader. This aspect mirrors the $5^{\text {th }}$ universal: exteriority. Even to oneself, speakers are talking as if they are speaking to another, the Alter $\mathrm{Ego}^{13}$ (4.1.). Responsivity precedes the dialogue, it makes language use happen (4.2.; Lévinas 1986; Mersch 2007; Jungbluth forthcoming). With responsivity we refer to the basic principle that speakers and authors use language to communicate with their audience. Without the other, imagined or real, they fall silent and no utterances are done at all.

\subsection{Alter $\neq$ Alius}

Important in our context is the difference between the other/s, who you talk to, and the other/s outside, who are not involved in the ongoing conversation. The choice of the other as ALTER, as the one you want to talk to, is the result of several preceding activities. In order to establish a space of interaction (Müller / Bohle $2007^{14}$ ) where the talk may take place later on, one starts to show oneself to the other. If the other pays attention, the two or more of them may take reciprocal notice of each other. The committed partners move to get closer and to form a dyad of conversation (Jungbluth 2005, pp. 19-23, 59-84, 129-137, 157-180, 202-204, 206; forthcoming). Only when these initiatives are completed felicitously may the communication start, for example by exchanging greetings with the other participants of the conversation.

Both Alter and Alius, who is the other, the one not involved, are Not-Ego. But the fact of selecting one or some of the Alius to become Alter makes them different with regard to Ego.

However, You is $[\mathrm{s} / \mathrm{h}$ he turned towards myself. While Ego and [s/]he (=Alius) appear due to internal and external perception, You is created by the spontaneity of election. You is Not-Ego too, but not as [s/]he in the sphere of all beings, but in a different one determined by the shared interaction. The [s/]he [her-]himself is not only a Not-Ego, but also a Not-You, and [s/]he stays not only in opposition to one of them, but to both ${ }^{15}$ (Humboldt 1827-29/1963, p. 228).

13 Take for example the writing of a diary, where the future recipient is often imagined as the author herself, albeit the author at a later moment in time.

14 "Spaces of interaction are multimodally constituted and establish the frame for focused interaction". (Müller / Bohle 2007, p. 136).

15 „IIch und Er sind an und für sich selbst verschiedne, so wie man eines von beiden denkt, nothwendig einander entgegengesetzte Gegenstände, und mit ihnen ist auch Alles erschöpft, denn sie heissen mit andren Worten Ich und Nicht-ich.] Du aber ist ein dem Ich gegenübergestelltes Er. Indem Ich und Er auf innrer und äusserer Wahrnehmung beruhen, liegt in dem Du Spontaneitaet der Wahl. $\{18\}$ Es ist auch ein Nicht-Ich, 
Together with the speaker-EGO, the partner vis-à-vis is inside of the dyad of conversation. The Alius is the foreigner somewhere else, not involved in the ongoing activity, socially excluded, outside of the space of interaction, outside of the dyad of conversation.

\subsection{I/WE: closing the gap}

Sameness emphasizes features we share, which are treated as the same. The „lone“ EGO includes her/his ALTER in a group of $\mathrm{WE}^{16}$. The specific generalized other (Mead 1980) refers to the experienced other in a social encounter or group. The relationship between the two or more of them gives rise to the self. The self depends on the other - it is the social part of the EGO as a result of the roles taken in a specific social context. The generalized other (Mead 1980) is close to the EGO in opposition to THEY, who are treated as different. Repeating Humboldt's words (see citation above) similar to HE, THEY are neither WE, nor YOU.

For example, in sports or politics, when two parties are competing against one another, the opposition between we and they is foregrounded. The otherness between the players or politicians belonging to the same team or party is treated differently from the otherness of the opponent:

In political discourse, there is a deep-going opposition between 'I/We' and 'They'. [..The relationship] can be reduced to the politician's acceptance of his allies' alterity and rejection of his opponents' alterity ${ }^{17}$ (Boicu 2007, p. 1).

The gap between the otherness ('allies' alterity') of those belonging to one and the same team or party and oneself is filled by giving preference to the sameness ${ }^{18}$ of all those who form part of one's own group. They are selected as YOU, depending on the context they may form part of WE, in either case they form part of the inside space. In doing so, the opponents are left outside. I rejects their alterity as Boicu states which is shown by calling them THEY.

aber nicht, wie das Er, in der Sphäre aller Wesen, sondern in einer andren, der eines durch Einwirkung gemeinsamen Handelns. In dem Er selbst liegt nun dadurch, ausser dem Nicht-Ich, auch ein Nicht-Du, und es ist nicht bloss einem von ihnen, sondern beiden entgegengesetzt (Humboldt 1827-29/1963, p. 228).

16 Compare the $I$ \& I reference replacing WE in Rasta-talk, used for ex. by the Bobo Ashanti Rastafari people.

17 allies 'friends, partners, collaborators' (antonyms: 'enemies, opponents, antagonists') $\neq$ alii!

18 See Tajfel 1981. 


\section{Voices [Identity versus Alterity]}

The gap towards the 'opponents' alterity' is, on the other hand, even more deepened. For example, 'citations' - or voices of the "other" party - are integrated "for the most part [by] words of another that are never found in the mouth of another" (Hastings/Manning 2004, p. 306).

\subsection{Performances and roles}

In many of the interviews centering on the groups perceived by the Greek community in Georgia ${ }^{19}$, intentionally performed mismatches between the roles of the author, the speaker and the perspectives on the issues uttered (called principal by Goffman), as well as the figures (Goffman 1974), the social persona indexed, play a role in the rhetorical strategies that establish who the ali $i^{20}$ in this specific context are.

Goffman divides the category of figure into 5 subcategories [natural figures, staged figures, printed figures, cited figures, mockeries or say-fors]. (Levon 2010, p. 16)

Remembering that the second refers to routines at the theatre and the third foregrounds fiction writing, all

[..] first three figures are characterized by the fact that there is only one figure on the stage at a time. In contrast "double-voicedness" is characteristic for the last two of them (Hastings/Manning 2004, p. 304).

The difference between the latter is rooted in reporting either the content in the case of citation while

[t] he final figure type, mockeries, is like cited figures in that it entails the quotation of speech explicitly attributed to another. Yet unlike straightforward citation, mockeries involve a focus on the form of an utterance, not its content, as a way of ridiculing the category of people of which that form is ideologically characteristic (Levon 2010, p. 16; see crossing Rampton 1995, style Coupland 2007).

Comparing the (true, really uttered) words of the others and the voices present in the cited figures of mockeries may be an important method to bring up the differences.

I agree with these authors on their analysis and strongly recommend taking these differences in the interpretation of our data into consideration, but I hesi-

19 See Stavros Skopeteas (University of Bielefeld) and Konstanze Jungbluth (EuropeanUniversity Viadrina), The impact of current transformational processes on language and ethnic identity: Urum and Pontic Greeks in Georgia, VW-Stiftung "Between Europe and the Orient" 2013-2016.

20 Plural of Alius. 
tate to reserve the term 'acts of alterity' to the last two figures. As any utterance is directed towards the other/s, it may always be analysed in terms of acts of identity and acts of alterity, whatever content or form it may take. The very selection of the words depends on the other (or in written discourse on the imagined other). Their materiality chosen, e.g. the performance is different when directed towards a child or an adult, a layman or an expert, a person of the same mother tongue or a stranger. The indispensable importance of the other for language use ${ }^{21}$ is obvious. In other words, one may refer to the thing in the world using different terms, and their selection depends on the horizon of understanding the speaker assumes on the side of her/his interlocutor/s. Once again, alterity is shown to be primordial even with regard to semanticity.

\subsection{Borders \& Spaces [inside versus outside; speaker-side versus hearer-side]}

Coming back to the borders drawn or changed in order to prepare the ground for starting a conversation, the committed (future) interlocutors interactively establish an inside and outside space. As has been outlined above (2.2.), there are several preceding activities depending on the context and its concrete embedding in certain social frames with their recognized routines (e.g. institutional frames). The selection of the Alter (or Alters) includes the decision on those who are left as Alius outside of the interaction that is about to begin.

To give a very instructive example, I refer to Müller and Bohle (2007; see 2.2), who meticulously describe the steps of approximation of a tango teacher pretending to give a lesson to one of the dance pairs moving around the floor. Taking into consideration the recognition of the roles of the involved persons (e.g. students, teacher) and the routines established between them due to earlier experienced instruction, the context of the interaction may be considered as a comparatively well-structured one. Nevertheless their research data show that an ongoing stepwise effort of the teacher is required until the attention of the dancing pair moves

21 The inclusion of the other represents an important step in the scientific development of different models taught in linguistics. Following Saussure (1857-1913) the materiality of the double-faced leaf of paper may be used to show the inseparable relationship between sign and referent (linguistic symbol: see 4.1. citation of Tomasello/Moll 2010), between the sound chain uttered by the speaker and the world. Based on this twosided idea and on the observation of language use in interaction and communication in general, the three-sided model introduced by Bühler (1879-1963) and visualized in the form of a triangle adds the hearer to the speaker and the world at the same level (see Figure 2 below). 
towards him. Both have to look at him and have to decide to open their constellation at a certain moment with the aim to integrate the teacher as the third person in their inner circle, which I call inside space. In doing so, they prepare together the situation where the teacher gives his instructions and the pair is ready to follow him. In other words the teacher being Alius has to be accepted as Alter by the two persons of the dance pair.

The same holds for encounters in previously less structured surroundings. My findings on data collected in activity embracing language use in Spain show that the establishment of an undivided inside space between the interlocutors ${ }^{22}$ is fundamental (Jungbluth 2005). Different from earlier assumptions (cf. Croft 1990), even in the case of deictic terms which inherently refer to spaces at different distances ${ }^{23}$, the underlying finality to act together usually gives preference to establishing a shared inside space without internal borders. The outside space surrounds this inside space and is endless. Of course, ongoing activity may change the earlier established space, and the involved participants may allow a former bystander (Alius) to become an Alter - an interlocutor in the following conversation. The example of the tango lesson shows the step-by-step opening up of a space belonging to a pair, to one extended between three persons.

Concerning further subdivisions, namely the establishment of a hearer-side space in opposition to a speaker-side one, there are only very few contexts where the drawing of a border-line dividing the inside space in two parts may be observed. The most obvious case is a turned-away position of the hearer towards the speaker. In the context of instruction at the work place, teachers are often standing behind their students, focusing on their activity and involved in a face-to-back ${ }^{24}$ conversation (Jungbluth 2005, pp. 64-70; forthcoming). Both are looking in the same direction, while the observed people are receiving advice on how to use tools on a workbench, or how to move computer tools when focusing together on activities on a screen. Another context which still needs further research may be a strongly hierarchized relationship between the involved interlocutors. In face-to-face conversations, some routines seem to suggest that touching things or possession may evoke the establishment of a hearer-side space in contrast

22 The space of interaction is not a space of concentric circles around the 'lonely' speaker (Hottenroth 1982; Diewald 1991).

23 See for example three term systems of demonstratives in Spanish, Finnish or Japanese (Jungbluth 2005, pp. 209-215).

24 The side-by-side space, rooted in a third positioning of speaker and hearer, is not discussed in this paper (cf. Jungbluth 2005; forthcoming). 
to a speaker-side one. The same holds to be true for contexts of quarrelling or disagreement.

Summing up, the different relations between EGO and ALTER, independently of being defined by spatial, social, among them personal parameters, determine the establishment of the relevant spaces. In face-to-face conversation, the undivided shared inside space is the unmarked case typically to be expected when spaces of interaction are established.

\section{Alterity (universal!)}

Most importantly, language use is directed towards the other. Without the interlocutor, even if imagined as Alter Ego, there is only silence. In the random case of speaking to oneself as if to another, the very name, Alter Ego, refers to the unmarked case of talking to another. The interlocutor is always Alter, elected by the speaker from the huge number of Alii, others who are not involved and therefore remain outside. The familiar - and at the same time minimal - constellation is the dialogue where two interlocutors talk to one another. Bigger groups of conversation are also common, and in general follow the patterns ritualized in dialogue.

Written language use is no exception. Even when writing, the dialogical practice is copied: the author has a future reader in mind. As the moment of reception may be chosen by the reader quite independent of the spatial-temporal anchored moment of writing, this form of communication may be understood as a (written) dialogue expanded within space and time ${ }^{25}$. The splitting-up of the acts of production and reception often needs re-actualization of the message to be adjusted to the new context determined by the addressee. Research on the delivery of legal documents, for example testaments, in (semi-) analphabetic societies ${ }^{26}$ transferred by messengers from the town to the countryside show that they accompany their action of handing over the text at another time and, if it is the case, at another place by explanations of the content to the recipient/s in order to support their understanding.

\subsection{Dialogue: speaker and hearer in the dyad of conversation}

The dialogue brings speaker and hearer together; they form the dyad of conversation.

Specifically, humans have evolved unique motivation and cognitive skills for understanding other persons as cooperative agents with whom one can share emotions, experience, and collaborative actions (shared intentionality) (Tomasello / Moll 2010, p. 331).

25 Cf. “zerdehnte Sprechsituation” Ehlich 1984.

26 See Jungbluth 1996 and references there. 
As other species also do, humans «coordinate their behaviors with that of the others in space and time», but what seems to be unique to humans «is the "togetherness" or "jointness" that distinguishes shared cooperative activities from other sorts of group actions» (Tomasello / Moll 2010, p. 334).

[Human cognitive skills] result from an ability enabling humans to put their heads together, so to speak, in cooperating and communicating with one another in ways that led to the creation of complex cultural products, including both material and symbolic artifacts, such as linguistic symbols (Tomasello/Moll 2010, p. 333).

In my opinion, this togetherness is the result of being able to differentiate between Alius and Alter. Only with the latter does one put heads together ${ }^{27}$ or does accept instructions (see 3.2.: students and their tango teacher; Müller/Bohle 2007). In doing so, the ground for togetherness is prepared. At least for the time of cooperation and communication, the otherness of the Alter is suspended in favor of establishing a shared space of interaction. The dialogue which takes place in this social context serves to prepare and coordinate all kind of joint actions and definitely precedes and further on accompanies the creation of material and symbolic artifacts. They are not only created but handed over from one to another, from one culture to another and passed down from one generation to another. In doing so, the tradition of material and symbolic artifacts takes place ensuring continuity of culture.

\subsection{Responsivity: altering - expressing - referring}

The three universals examined in this paper, alterity, creativity and semanticity, lead to the three activities realized by the speaker as part of Bühler's triangle: altering, expressing and referring. By changing the order of the three basic activities characteristic of any language use in such a way that their first letters form the word EAR, the importance of the simultaneous activities of the hearer and her efforts to create understanding are foregrounded.

27 This is the case even in discourses of disagreement which are rooted in a shared space of interaction, too. 
Figure 2: The three basic activities of the speaker: expressing, altering, referring are directed towards the hearer (see triangle of Bühler, 1934). Her activities of reception start with the perception of the signals by her ears.

\section{$\mathrm{H}($ earer)}

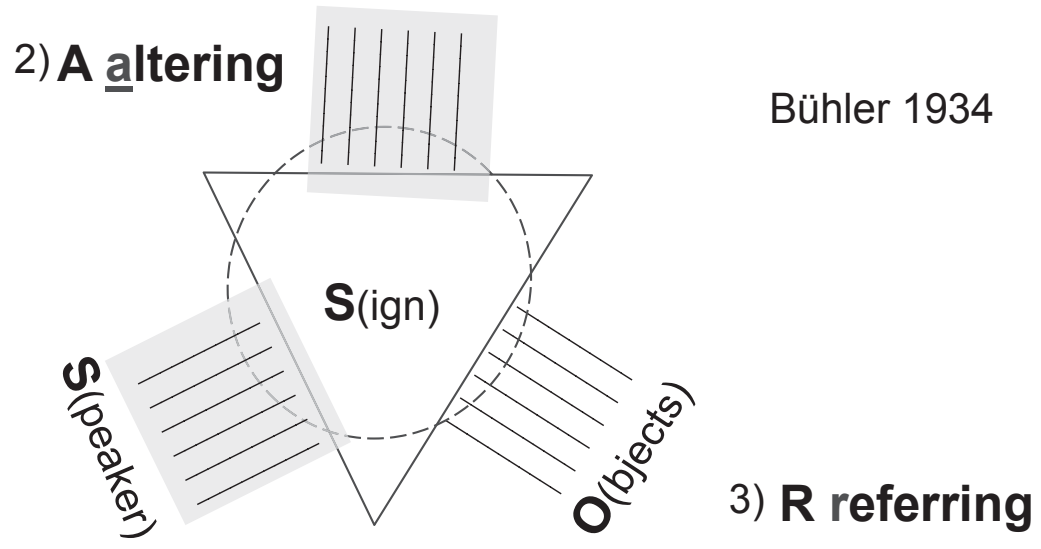

1) E expressing

\section{Conclusions}

Language use, whether spoken or written, is always directed towards the other, the Alter. The dialogical principle inherent to language confirms that alterity must be given priority among the language universals, preceding creativity, semanticity, historicity and exteriority. When the speaker participating in an ongoing conversation no longer carries out her activities of altering, expressing and referring, or the hearer stops her reception of these activities, the dialogue does not continue. They may go on with their social interaction, but they no longer use language. The real or imagined presence of the other is fundamental to any language use.

With regard to the internal hierarchy between the five universals, it is not by chance that the edges of Bühler's triangle mirror the first three of them: alterity represented by the hearer, creativity by the speaker, and semanticity by the world one refers to. With regard to the latter, the very choice of words referring to one and the same thing or state of affairs in the world depends on the interlocutor 
(see 3.1.), which proves the priority of alterity over semanticity to be true. At the same time, this dependency also determines the ways the speaker may express herself. The utterances are different when directed towards children, as it varies in a characteristic way when experts are discussing research between themselves or when general public is present. While historicity, one of the two other universals, foregrounds the rooting of the prominent artefact language in the collective memory, exteriority emphasizes the materiality of language use in its spoken or written form. Both refer to concrete historical languages such as Georgian, Pontic Greek or Urum, which are examples of human language use within a concrete space or spaces at a certain moment in historical time up to now.

Alterity comes into play when the respective communities perceive themselves as different from one another, instead of their equally possible option to give preference to emphasize the sameness of some or all of them. To the ones they select as same alterity is given, the others are left outside and stay as alii ('they'). The concept of otherness is not restricted to pairs or small groups of people, but may be extended to large social groups such as those defined by ethnicity. This concept is often rooted in the use of one and the same language, thus giving evidence of the collective memory; however, other parts of the collective memory may override the difference even between mutually exclusive languages. The example of the Greek community in Georgia obviously does so. They foreground other parts of sameness to render their shared collective memory. In the context of discourses within society at large, instead of focusing on what is different, we may as well underscore what we have in common. Otherness always presupposes sameness; identity ${ }^{28}$ is just another word for it.

\section{References}

Aboulafia, Mitchell: “George Herbert Mead”. In: Edward N. Zalta (ed.): The Stanford Encyclopedia of Philosophy. 2012, retrieved 7.4.2015, from http://plato. stanford.edu/archives/sum2012/entries/mead/.

Albrecht, Jörn / Lüdtke, Jens / Thun, Harald (eds.): Energeia und Ergon. Sprachliche Variation - Sprachgeschichte - Sprachtypologie. Studia in honorem Eugenio Coseriu. Band I-III. Narr: Tübingen 1988.

Assmann, Aleida: Erinnerungsräume. Formen und Wandlungen des kulturellen Gedächtnisses. Beck: München 1999.

28 See Raible 1998 and the English translation of the German word Identität in English [...sameness (identity)]. 
Assmann, Jan: Das kulturelle Gedächtnis. Schrift, Erinnerung und politische Identität in frühen Hochkulturen. Beck: München 1982.

Baumann, Gerd / Gingrich, Andre: Grammars of Identity/Alterity: A Structural Approach. Berghahn: New York/Oxford 2004.

Beck-Gernsheim, Elisabeth: Wir und die Anderen : vom Blick der Deutschen auf Migranten und Minderheiten. Suhrkamp: Frankfurt am Main 2004.

Blank, Andreas: Prinzipien des lexikalischen Bedeutungswandels am Beispiel der romanischen Sprachen. Niemeyer: Tübingen 1997.

Boicu, Ruxandra: "Pragmatic identity and alterity in political discourse". University of Bucharest Review, A Journal of Literary and Cultural Studies, Vol IX, 4, 2007, pp. 76-83.

Boix-Fuster, Emili: “Llengües i identitats a Europa”. In: Massip, Àngels (ed.): Llengua $i$ identitat. UB-Press: Barcelona 2008, pp. 133-150.

Bühler, Karl: Sprachtheorie. Fischer: Stuttgart (1982 [1934]); Teoría del lenguaje, translated into Spanish by Julián Marías. Alianza: Madrid 1950; Theory of Language, translated into English by Donald F. Goodwin. Benjamins: Amsterdam 1990.

Coseriu, Eugenio: "Les universeaux linguistiques (et les autres)". In: Proceedings of the $11^{\text {th }}$ intern. Congress of Linguists I. Bologna 1974, pp. 47-73; dt. Übersetzung von G. Breitenbürger: „Die sprachlichen (und die anderen) Universalien“. In: Schlieben-Lange, Brigitte (ed.): Sprachtheorie. Hoffmann \& Campe: Hamburg. pp. 127-161.

Coseriu, Eugenio: Synchronie, Diachronie und Geschichte. Das Problem des Sprachwandels. Fink: München 1974.

Coupland, Nicholas: Style: Language and identity. CUP: Cambridge 2007.

Croft, William: Typology and universals. CUP: Cambridge 1997.

Derrida, Jacques: Die Schrift und die Differenz. Suhrkamp: Frankfurt am Main 1972.

Derrida, Jacques: Adieu! Nachruf auf Emmanuel Lévinas. Hanser: München 1999.

Diewald, Gabriele: Deixis und Textsorten im Deutschen. Niemeyer: Tübingen 1991.

Duszak, Anna: Us and Others. Social identities across languages, discourses and cultures, Benjamins: Amsterdam 2002.

Ehlich, Konrad: „Zum Textbegriff“. In: Annely Rothkegel/ Barbra Sandig (eds.): Text, Textsorten, Semantik. Buske: Hamburg 1984, pp. 9-25.

Goffman, Erving: Frame analysis: An essay on the organization of experience. Harvard University Press: Cambridge 1974.

Goffman, Erving: Forms of talk. University of Pennsylvania Press: Philadelphia 1981. 
Hastings, Adi / Manning, Paul: Acts of Alterity: Introduction. Elsevier: Oxford 2004, pp. 291-311.

Hottenroth, Priska: "The System of Local Deixis in Spanish". In: Weissenborn, Jürgen / Klein, Wolfgang (eds.): Here and There. Cross-linguistic Studies on Deixis and Demonstration. Benjamins: Amsterdam 1982, pp. 133-153.

Huizing, Klaas: Das Sein und der Andere : Lévinas' Auseinandersetzung mit Heidegger. Athenäum: Frankfurt am Main 1988.

Humboldt, Wilhelm von: Ueber die Verschiedenheiten des menschlichen Sprachbaues. (1827-1829. Erstdruck in: Gesammelte Schriften, Band 6, Berlin 1907, Darmstadt 1963) 2. Von der Natur der Sprache und ihrer Beziehung auf den Menschen im Allgemeinen. In: Werke in fünf Bänden. Band 3, Darmstadt 1963, pp. 191-230.

Jańczak, Barbara / Jungbluth, Konstanze / Weydt, Harald (eds.): Mehrsprachigkeit aus deutscher Perspektive. Narr: Tübingen 2012.

Jungbluth, Konstanze (forthcoming): "Positions - Constellations - Practices: Referring to the space in front of the hearer". In: Da Milano, Federica (ed.): Space and Language: on Deixis. Benjamins: Amsterdam.

Jungbluth, Konstanze / Meierkord, Christiane: Identities in migration contexts. Narr: Tübingen 2007.

Jungbluth, Konstanze: Pragmatik der Demonstrativpronomina in den iberoromanischen Sprachen. De Gruyter, Imprint Niemeyer: Berlin/Tübingen 2005.

Jungbluth, Konstanze: Die Tradition der Familienbücher. Das Katalanische während der Decadència. De Gruyter, Imprint Niemeyer: Berlin/Tübingen 1996.

Lehmann, Christian: „Zu Eugenio Coserius Sprachtypologie“. In: Albrecht, Jörn / Lüdtke, Jens / Thun, Harald (eds.): Energeia und Ergon. Sprachliche Variation - Sprachgeschichte - Sprachtypologie. Studia in honorem Eugenio Coseriu. Band III. Das sprachtheoretische Denken Eugenio Coserius in der Diskussion (2). Narr: Tübingen 1988, pp. 3-22.

Kabatek, Johannes / Murguía, Adolfo / Coseriu, Eugenio: «Die Sachen sagen, wie sie sind...»: Eugenio Coseriu im Gespräch. Narr: Tübingen 1997.

Lévinas, Emmanuel: Totalität und Unendlichkeit. Alber: Freiburg 1993.

Mead, George Herbert (1980), Footnote 3 citation follows Stanford Encyclopedia of Philosophy, lemma G.H. Mead by Mitchell Aboulafia (2012) http://plato. stanford.edu/entries/mead/\#RolSelGenOth

Mersch, Dieter: „Die Frage der Alterität“. In: Dalferth, Ingolf / Stoellger, Philipp (eds.): Hermeneutik der Religion. Mohr/Siebeck: Tübingen 2007, pp. 35-54. 
Müller, Cornelia / Bohle, Ulrike: „Das Fundament fokussierter Interaktion“. In: Schmitt, Reinhold (ed.): Koordination. Analysen zur multimodalen Interaktion. Narr: Tübingen 2007, pp. 129-166.

Raible, Wolfgang: „Alterität und Identität [Otherness and sameness (identity)]“. In: Schlieben-Lange, Brigitte (ed): LiLi 110: Alterität, 1998, pp. 7-22.

Rampton, Ben: Crossing: language and ethnicity among adolescents. Longman: London 1995.

Schlieben-Lange, Brigitte: „Alterität als sprachtheoretisches Konzept“. LiLi 110, 1998, pp. 41-57.

Schütze, Fritz: „Interaktionspostulate - am Beispiel literarischer Texte“. In: HessLüttich, Ernest W.B. (ed.): Literatur und Konversation. Athenaion: Wiesbaden 1980, pp. 72-94.

Sonesson, Göran: “La semiosfera y el dominio de la alteridad". Entretextos 6, 2005, retrieved 7.4.2015, from http://www.ugr.es/ mcaceres/Entretextos/entre6/sonesson.htm

Tajfel, Henri: Human groups and social categories. CUP: Cambridge 1981.

Tomasello, Michael / Moll, Henrike: "The Gap is Social: Human Shared Intentionality and Culture". In: Kappeler, Peter M. / Silk, Joan B. (eds.): Mind the Gap. Tracing the Origins of Human Universals. Springer: Berlin 2010, pp. 331-350.

Weiand, Christof: «Libri di famiglia» und Autobiograhie in Italien zwischen Treund Cinquecento. Stauffenburg: Tübingen 1993.

Wilhelm, Raimund: „Diskurstraditionen“. In: Haspelmath, Martin et alii (eds.) Sprachtypologie und sprachliche Universalien. 1. Halbband. De Gruyter: Berlin 2001, pp. 467-477. 



\title{
Dagna Zinkhahn Rhobodes \\ (Frankfurt/Oder)
}

\section{The permeability of language borders on the example of German-Polish language mixing}

\begin{abstract}
In dem vorliegenden Artikel werden Prozesse der Öffnung und Überschreitung von sprachlichen Grenzen basierend auf der Analyse der deutsch-polnischen Korpusdaten beschrieben und erklärt. Die in diesem Beitrag dargelegte Diskussion bildet einen Teil von einem interdisziplinären Ansatz zur Verschränkung des kulturwissenschaftlich geprägten Begriffs der Grenze mit ihren drei Dimensionen - der Durabilität, Permeabilität und Liminalität - in die linguistische Untersuchung von Sprachkontaktphänomenen. Der Fokus des vorliegenden Artikels liegt insbesondere auf der Diskussion des Aspekts der Permeabilität. Der permeable Charakter der sprachlichen Grenzen wird an unterschiedlichen strukturellen Stellen des Sprachwechsels - von der Satz-, über Phrase- und Wort- bis hin zur Morphemgrenze - erörtert.

Das Ziel des vorliegenden Artikels ist es, einen integrativen Ansatz vorzuschlagen, welcher die Theorie der Grenze in die linguistische Analyse integriert und somit einen interdisziplinären Einblick in die Erforschung der strukturellen Aspekte des Sprachkontakts liefert.
\end{abstract}

Schlagworte: Sprachgrenze, Permeabilität, deutsch-polnische Sprachmischung

Keywords: language border, permeability, German-Polish language mixing

\section{Introduction}

The processes of opening, crossing and blurring of language borders in the context of globalization and migration processes have become a common part of everyday communication in multilingual contexts. Such multilingual settings include border regions characterized by language contact beyond national borders. An example of intense cross-border language contact in various social and situational contexts is the German-Polish border city pair of Frankfurt/Oder and Słubice, considered to be one of the most important points of German-Polish contact in the border region (cf. Kimura 2013, p. 111). ${ }^{1}$ Through educational, cultural and economic collaboration, Polish and German speakers come into contact with each

1 Kimura, Goro Christoph : "Strategie komunikacji językowej na polsko-nemieckim pograniczu." In: Koutny, Ilona / Nowak, Piotr (eds.): Język. Kommunikacja. Informacja. Language. Communication. Information. (Poznań), 8/2013, pp. 109-124. 
other in various institutions (for example, in secondary schools with exchange programs, or at the European University Viadrina, with $75 \%$ German and $10 \%$ Polish students), but also during everyday social interactions of inhabitants from different ages groups and social backgrounds.

This intense language contact often leads to creative use of German-Polish mixed language forms and constructions established and practised in the spontaneous everyday language routine. Such language mixing phenomena ${ }^{2}$ show that language use in multilingual contexts provides a scope for permeability between language systems: "At the same time phenomena such as code-switching or codemixing in the language use of multilingual speakers show that languages offer a room for permeability" 3 (Cunha et al. 2012, p. 13, my translation). ${ }^{4}$ From this perspective, I consider the emergence of language mixing phenomena as a result of the opening and crossing of language borders. The language border is regarded here as the structural border between two language systems, mostly phonetically manifested as the site of language switch. Following Greco/Renaud/Taquechel (2013), it can be interpreted from the dialectological tradition as the dividing line between two "language spaces" which can be passed through by moving from the use of one language to another. ${ }^{5}$ If the language contact is extensive enough that it leads to convergence - and maybe fusion - of morphosyntactic language structures, and in consequence to the emergence of hybrid language forms, it may even lead to the dissolution of language borders.

But what does it actually mean to open and cross a language border? How can these concepts - which have thus far primarily been regarded metaphorically - be

2 I use the term language mixing phenomena according to Földes $(2005$, pp. 68-69, 71) as generic term for a variety of language contact inducted phenomena characterized by synchronic lexical and structural combination of two languages (or varieties). They include:

a) the alternating use of more than one language by a single speaker within a conversation

b) the language-contact-induced phonological, morphological, syntactic and lexical influence between the languages.

3 "Gleichzeitig zeigen Phänomene wie beispielsweise Code-switching oder Code-mixing bei multilingualen Sprechern, dass Sprachen Spielraum für Durchlässigkeit bieten.”

4 Cunha, Conceição et al. (eds.): Über Grenzen sprechen. Mehrsprachigkeit in Europa und der Welt. Königshausen \& Neumann: Würzburg 2012.

5 "More in resonance with the viewpoints and ambitions of linguistic anthropology (Duranti 1997), we therefore finally converged on the dialectological tradition, on that is familiar with the concept 'speech variety' (fr. parler) and its problematic borders (Straka/Gardette 1973) and sensitive in its empirical approach to the organisation by the witnesses themselves of their day-to-day experience of linguistic diversity and its 'borders' or 'discontinuities', crossed in moving from one way of speaking to another as well as in the geographical traversal of a fragmented space (Walt et al. 1973, Poche 1996)" (Greco/Renaud/Taquechel 2013, p. 44). 
described and explained from a linguistic perspective? Which processes actually take place at the language border between two languages in contact, and what are the structural consequences of these dynamic phenomena? How can the previously mentioned permeability of language borders be systematically examined?

In the following article, I submit a proposal for describing and explaining the concepts of opening and crossing language borders based on the discussion of German-Polish language mixing data selected mainly from Frankfurt (Oder) and its twin city of Słubice. Thus, the term of the border is relevant in two aspects of the study. Firstly, the empirical data are mostly collected along the German-Polish border; secondly, the language border character in the data itself is the main object of research. Based on the analysis of selected examples, I will discuss the permeable character of language borders at different structural sites of language switch, beginning with the language switch at the clause border, followed by the phrase border, word border, and finally the morpheme border.

The data will be analysed by applying the concept of the border from the perspective of cultural science studies (cf. Audehm / Velten 2007, Jungbluth 2012) ${ }^{6}$, . Applying this heretofore-underused approach in linguistics, I propose a culturalstudies influenced viewpoint in the investigation of language mixing, and contribute to the theory of borders from the linguistic perspective.

The paper is divided into six sections. After presenting the theoretical framework in chapter two, the object of investigation and the methodological approach will be described in chapter three. The data analysis approach will be presented in chapter four. The fifth section is dedicated to the discussion of some examples of GermanPolish language mixing. Chapter six summarizes the article with conclusions.

6 Cf. Audehm, Katrin / Velten, Hans Rudolf (eds): Transgression, Hybridisierung, Differenzierung, Zur Performativität von Grenzen in Sprache, Kultur und Gesellschaft. Rombach: Freiburg 2007.

Jungbluth, Konstanze: „Aus zwei mach eins: Switching, mixing, getting different“. In: Jańczak, Barbara/ Jungbluth, Konstanze/ Weydt, Harald (eds.): Mehrsprachigkeit aus deutscher Perspektive. Narr: Tübingen 2012, pp. 45-72.

7 Further cultural science studies focussing on the concept of the border are among others: Faber, Richard / Naumann, Barbara (eds.): Literatur der Grenze - Theorie der Grenze. Königshausen \& Neumann: Würzburg 1995.

Rolf Parr: „Liminale und andere Übergänge. Theoretische Modellierungen von Grenzzonen, Normalitätsspektren, Schwellen, Übergängen und Zwischenräumen in Literatur und Kulturwissenschaft“. In: Geisenhanslüke, Achim/Mein, Georg (eds.): Schriftkultur und Schwellenkunde, transcript: Bielefeld 2008, pp. 11-64.

Geisen, Thomas / Karcher, Allen (eds.): Grenze: Sozial - Politisch - Kulturell. Ambivalenzen in den Prozessen der Entstehung und Veränderung von Grenzen. IKO-Verlag: Frankfurt am Main 2003. 


\section{The concept of the border and contact linguistics}

\subsection{Language mixing as a result of crossing of language borders}

The concept of language mixing as a crossing of language borders has already been mentioned in the language contact literature as "Sprachgrenzen überspringen" ("to jump over language borders") (Hinnenkamp / Meng 2005), , "Überschreiten von Sprachgrenzen" ("crossing the language borders") (Cunha et al. 2012, p. 13) or "crossing" (Rampton 2005). ${ }^{9}$ Gogolin $(1998)^{10}$ calls the language mixing routine of multilingual speakers "sprachliches Grenzgängertum"."1

Földes (1996) ${ }^{12}$ illustrates language mixing as a crossing of language borders:

One of their essential characteristics is that the bilingual speaker (in the bilingual discourse or interaction mode) regularly takes elements, structures and patterns from the other language (or variety) and/or alternately uses the languages, which leads to the emergence of different types of language mixing. [...] Members of bi- or multilingual communities do not usually keep their languages separated, but rather creatively cross the language borders in their spoken communicative everyday practice by using communicative patterns of different linguistic and cultural systems for their effective communication. ${ }^{13}$ (Földes 1996, p. 12, my translation)

8 Hinnenkamp, Volker / Meng, Katharina (eds.): Sprachgrenzen überspringen. Sprachliche Hybridität und polykulturelles Selbstverständnis. Narr: Tübingen 2005.

9 Rampton, Ben: Crossing: language and ethnicity among adolescents. St. Jerome Press: Manchester 2005.

10 Gogolin, Ingrid: „Sprachen rein halten - eine Obsession“. In: Gogolin, Ingrid / List, Günther / Graap, Sabine (eds.): Über Mehrsprachigkeit. Stauffenburg-Verlag: Tübingen 1998, pp. $71-96$.

11 '"Linguistic border crossing', as one of the central results of our study, is a common feature of the linguistic practice of multilingual speakers. Blending of or switching between languages not only occur 'out of necessity' or unnoticed by the speakers itself [...]. It is rather, as it seems, a 'stylistic device' of multilingual people and often a result of a conscious choice." (Gogolin 1998: 75, translation D.Z.R.)

„,Sprachliches Grenzgängertum' so eines der zentralen Ergebnisse unserer Untersuchung, ist ein gewöhnliches Merkmal der sprachlichen Praxis Mehrsprachiger. Das Vermengen von oder Wechseln zwischen Sprachen geschieht keineswegs nur ,der Not gehorchend' oder als von den Sprechenden selbst unbemerkt vollzogene Routine [...]. Vielmehr ist es, wie es scheint, darüber hinaus ein ,Stilmittel' mehrsprachiger Menschen, nicht selten Ausdruck einer bewussten Wahl.“ (Gogolin 1998: 75)

12 Földes, Csaba: Mehrsprachigkeit, Sprachenkontakt und Sprachenmischung. (Flensburger Papiere zur Mehrsprachigkeit und Kulturenvielfalt im Unterricht; 14/15). Flensburg 1996.

13 „Eines ihrer hervorstechender Merkmale besteht darin, dass der bilinguale Sprecher (im zweisprachigen Diskurs- bzw. Interaktionsmodus) z. B. regelmäßig aus der jeweils 
Greco/Renaud/Taquechel (2013) provide an interesting approach in which the authors analyse linguistic practices in multilingual workplaces, taking a conversational analysis perspective. They consider the alternating use of two or more languages within one conversation as "border-crossing", understood as "leaving one language space for another" (Greco/Renaud/Taquechel 2013, p. 36). ${ }^{14}$

However, in the aforementioned citations, the concept of the language border and the processes of its crossing are considered mostly metaphorically. The actual character of the language border and its dynamic change during the "crossing" and "moving" has not been a direct object of systematic investigation. Jungbluth (2012) offers an important contribution to the discussion of the character of language borders. She discusses and compares the alteration and grade of language border violation at different structural points of language switch in several language pairs, including Spanish-German, Italian-German, Brazilian/PortugueseGerman, English-German and Polish-German.

\subsection{Durability, permeability and liminality of language borders}

In this chapter, the three essential concepts for the language borders analysis durability, permeability and liminality - will be introduced. The following schematic diagrams are simplified illustrations representing the concepts of durability, permeability and liminality. The three circles stand for the three levels of analysis in my corpus data: phonetic (P), morphological (M) and syntactic (S).

Durability refers to the density and the stability of borders. Durable language borders are clearly identifiable and constitute an impermeable barrier between two languages. There is no reciprocal phonetic, morphological or syntactic influence between the language systems, and they are consequently assumed to be clearly

anderen Sprache (bzw. Varietät) Elemente, Strukturen und Muster übernimmt und/ oder die Sprachen abwechselnd benutzt, was zu verschiedenen Arten von Sprachmischung führt. [...] Mitglieder zwei- bzw. mehrsprachiger Gemeinschaften trennen nämlich ihre Sprachwelten in aller Regel nicht strikt, sondern überschreiten in ihrer gesprochensprachlicher kommunikativen Alltagspraxis kreativ die Grenzen einer Sprache, indem sie kommunikative Möglichkeiten aus mehreren sprachlichen und kulturellen Systemen in den Dienst einer effektiven Kommunikation stellen."

14 „Inspired by the tradition of dialectological investigations and by forming an analogy with the concept of, dialect variation areas', we examined, in the 'language space' opened by any interaction, the implementation of phenomena we have called 'border crossing', which can signify on the one hand the limit reached by specific 'ways of doing', and on the other the anchoring of this process in a new 'language space' categorised and treated as referring to other 'ways of doing"' (Greco/Renaud/Taquechel 2013, p. 34). 
separated from one another. The language switch is often anticipated through flagging (cf. Poplack 1980) ${ }^{15}$ - realised as pause, interjection, explicit metalinguistic commentary, laughing etc. - which draws attention to the following switch.

Figure 1: Durability of language borders

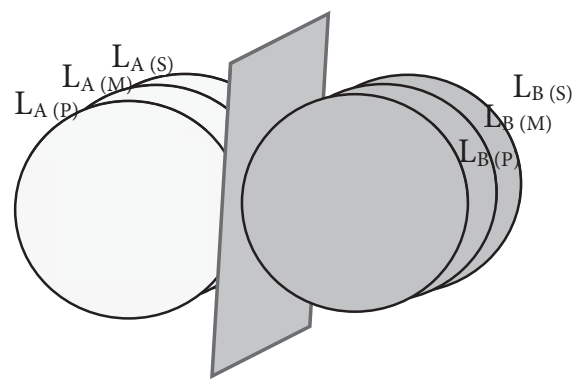

Permeability refers to the opening and transgressing of borders. Permeable language borders are still observable, but they are not stable and impassable. They constitute a penetrable threshold which enables reciprocal phonetic, morphological and/or syntactic impact between two languages in contact.

Figure 2: Permeability of language borders ${ }^{16}$

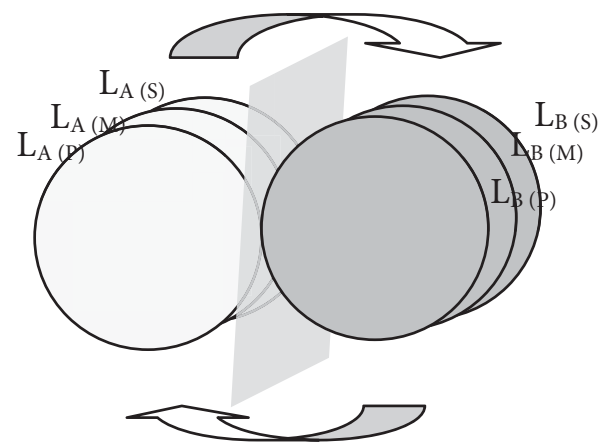

15 Poplack, Shana: "Sometimes I'll start a sentence in Spanish y termino en Español: Toward a typology of code-switching". In: Linguistics 18, 1980, pp. 581-618.

16 As we will see in the analysis of the examples of German-Polish language mixing, the transfer of the phonetic, morphological or syntactic elements will be rather asymmetrical. 
The concept of liminality was coined by Turner $(1964,1998),{ }^{17}$ and reflects the idea that borders are not simply lines, but that they also constitute border zones. These border zones can be considered as transition areas, overlapping spaces, "lieux de passage" (Erfurt 2005, p. 19) or "grey areas" (Clyne 2000, p. $273 ;{ }^{18}$ McCormick 2002). ${ }^{19}$

Figure 3: Liminality of language borders

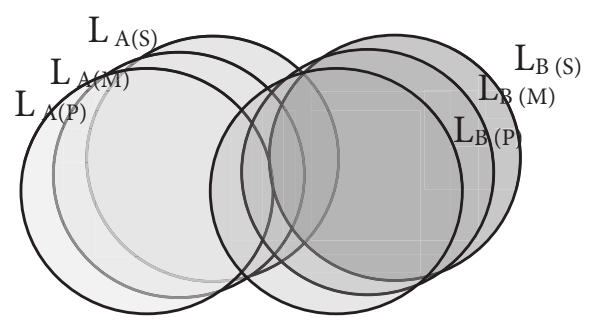

Border zones can also be understood as "third spaces" and "in-between spaces" according to Bhabha (1994). ${ }^{20}$ Such overlapping spaces can also arise at the border between two languages in contact, forming "new spaces of multilingualism" (Erfurt 2003, p. 6) or "third spaces in the language" (Gugenberger 2005). ${ }^{21}$

In these liminal spaces, as I will call them, hybrid, syncretic, and sometimes even autonomous language forms may emerge as a result of the reciprocal influ-

17 Turner, Victor W.: "Betwixt and Between: The Liminal Period in Rites de Passage". In: Helm, June (ed.): Symposium on New Approaches to the Study of Religion: Proceedings of the 1964 Annual Spring Meeting of the American Ethnological Society. American Ethnological Society: Seattle 1964, pp. 4-20.

Turner, Victor W.; "Liminalität und Communitas". In: Belliger, Andréa / Krieger, David J. (ed): Ritualtheorien. Westdeutscher Verlag: Opladen/Wiesbaden. 1998, pp. 251-262.

18 Clyne, Michael: „Constraints on code-switching: how universal are they?” In: Wei, Li (ed.): The Bilingualism Reader. Routledge: London 2000, pp. 257-80.

19 McCormick, Kay: Language in Cape Town's District Six. Oxford University Press: Oxford 2002.

20 Bhabha, Homi: The Location of Culture. Routledge: London 1994.

21 Gugenberger Eva: „Der dritte Raum in der Sprache. Sprachliche Hybridisierung am Beispiel galicischer Migrant/inn/en in Buenos Aires“. In: Cichon, Peter/ Czernilofsky, Barbara/ Tanzmeister, Robert/ Hönigsperger, Astrid (eds.): Entgrenzungen. Für eine Soziologie der Kommunikation. Praesens: Wien 2005, pp. 354-376. 
ence and blending of grammatical structures. Here, it is no longer clear where exactly the language border runs. The classification and allocation of linguistic elements to one language or the other becomes difficult.

In this paper, I will concentrate on the analysis of the aspect of permeability. Two other qualities of the border - durability and liminality - are discussed in Zinkhahn Rhobodes (forthcoming) as well as in my dissertation (Zinkhahn Rhobodes, forthcoming).

\section{Methodology}

The data collection was carried out in three investigation sites. The first two are both educational institutions situated in Frankfurt (Oder) and Słubice. The initial part of the empirical study took place at the European University Viadrina, where Polish students have established a German-Polish mixed speech. This mixed language routine is widely practiced as their common group code in everyday interactions. Its speakers call this language routine Viadrinisch (from the name of the University) or Poltsch (from the names of languages involved

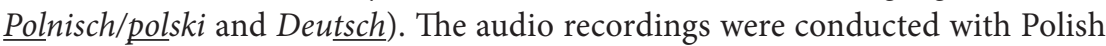
law and cultural science students during several semesters. All of the informants are Polish native speakers from different parts of Poland who learned German as a foreign language in secondary school.

Data from the second location were collected in Frankfurt (Oder) at the KarlLiebknecht-Gymnasium. The informants are pupils of the $10^{\text {th }}$ and $11^{\text {th }}$ grade who - like the students of the European University Viadrina - are Polish native speakers. They mostly come from Słubice or Polish villages and towns near the border region.

The third investigation site is the Robert-Jungk-Oberschule in Berlin, which is also a secondary school particularly known for its German-Polish educational profile (SESB - Staatliche Europaschule Berlin). Similar to the Karl-LiebknechtGymnasium, the interviewed pupils of Polish origin attended the $10^{\text {th }}$ and $11^{\text {th }}$ grade. However, contrary to the students and pupils in Frankfurt (Oder), they attended primary school, and some even went to kindergarten in Germany.

In these three educational institutions, Poles study and learn in German together with German classmates and use the linguistic material of the Polish and German languages as a resource for their everyday communication, and in doing so, they form creatively mixed German-Polish forms.

The basis for the qualitative part of the investigation is a series of audio recordings. The interviews were conducted with 36 informants and provided language 
material totalling 12 hours. The informants were asked, among other things, to describe their typical day at school or university, as well as their favourite subjects and hobbies. The interviews were conducted mostly on the school/university campus with groups of 2-5 Polish native speakers. ${ }^{22}$

In the following chapter, some examples from the corpus will be discussed. The analysis forms part of my dissertation and represents the current stage of work on my thesis.

\section{The approach}

In order to examine the concept of language mixing with its wide spectrum of language contact-induced phenomena, I focus on its characteristics at different levels of increasing morphological, syntactic and phonetic cross-linguistic influence. The examples of language mixing from the corpus are thus divided into four groups, following the continuum of increasing impact on language structures. The starting point in the continuum is a language switch at the clause boundary. The second group contains examples of language switch taking place at the intra-sentential level - at the phrasal boundary. In the next group, language switch affects the language structures even more - it occurs at the word boundary. And the last level includes examples with highest impact on language structures: the language switch at the grammatical unit of the morpheme boundary.

Aside from the differentiation of language switch at different structural borders, the character of these language borders is analysed at each of the mentioned levels, applying the three introduced aspects of the border theory: namely durability, permeability and liminality. Thus, language switch at each of four structural borders is discussed according to its durable, permeable and liminal characteristics:

22 Data were collected during the time period $05.2012-03.2013$. 
Figure 4: Analysis model
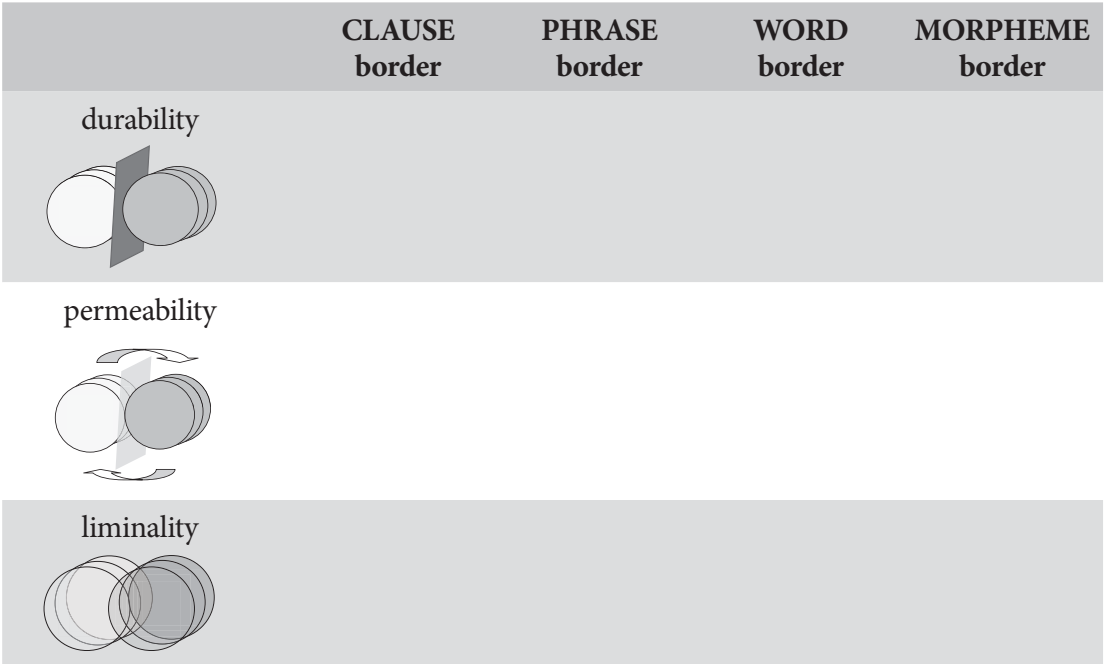

In the following, the aspect of permeability will be discussed based on selected examples from the corpus. Concerning the analysis of the remaining two qualities of language borders - the durability and liminality - I refer interested readers to Zinkhahn Rhobodes (forthcoming) where I discussed the durable, permeable and liminal character of language switch at the morpheme border as well as to my dissertation (Zinkhahn Rhobodes, forthcoming), where the complete model is presented and each of its levels is thoroughly discussed showing various examples from the corpus.

\section{The analysis of selected examples}

\subsection{Language switch at the clause border}

Example 1: Mamy Potenzregel

\begin{tabular}{|l|l|l|l|}
\hline R.11.KLG. & Mamy & Potenzregel. & $\begin{array}{l}\text { No ona mówi o tym, że }((1,5 \mathrm{~s})) \mathrm{xn} \bullet \\
\text { to sie równa }((1 \mathrm{~s})) \mathrm{n}\end{array}$ \\
\hline [translation] & We have & power rule. & Well it states that, $((1,5 \mathrm{~s})) \mathrm{xn} \bullet$ equals $((1 \mathrm{~s})) \mathrm{n}$ \\
\hline
\end{tabular}

23 Abbreviations: A - first latter of the informants name, 12 - class/semester, RJO - acronym of the school/university name (Robert Jungk Oberschule), KLG (Karl-Liebknecht Gymnasium), EUV (Europa-University Viadrina). 
Let's focus on the character of the language border between the German-Polish mixed clause Mamy Potenzregel, and the Polish clause No ona mówi o tym, że (...). The switch between the German noun Potenzregel and the Polish clause can be considered as alternation (Muysken 2000, p. 7), as there is no embedding of a constituent from one language into a construction of another. However, although Polish and German are clearly separated from each other, there is a cohesion across the language border between the German Potenzregel and Polish clause No ona mówi o tym, że. This cohesion is created by the Polish pronoun ona (she), showing a number and gender agreement with the German noun Potenzregel from the previous clause. We observe a clear agreement in gender between these two elements: Regel is feminine (as well as its Polish counterpart reguta) and the pronoun ona in the next clause reflects the same gender. Furthermore, there is no distinct pause anticipating the language switch, which can thus be considered as "smooth" 24 according to Poplack (1987, p. 54). ${ }^{25}$ Accordingly, due to building of cohesion and transfer of grammatical features across the language border at the site of language switch between the German noun and the Polish clause, the language border in this example can be considered as permeable.

\subsection{Language switch at the phrase border}

Let's analyse the language switch at the phrase border between the Polish demonstrative pronoun and the German nominal phrase in the following example:

Example 2: Taki große Übung

\begin{tabular}{|l|l|l|l|}
\hline M.3.EUV & taki & große Übung & i yyy dostajemy tak jakby przypadek. \\
\hline [Translation] & (such) a & big excersise & and uh we receive a sort of a case. \\
\hline [Phonetics (data)] & & grose ibun & \\
\hline [Phonetics (Ger. norm)] & & gro:se '?y:bun & \\
\hline [Syntax $]^{26}$ & $\begin{array}{l}\text { [NP[PDAT: taki][ADJA: } \\
\text { große][NN: Übung] }\end{array}$ & \\
\hline
\end{tabular}

24 "Characteristics of smooth CS include copious occurrences, smooth transitions between languages, and lack of rhetorical effect." (Poplack 2004, p. 593)

25 Poplack, Shana: "Contrasting patterns of code-switching in two communities." In: Wande, Erling / Anward, Jan / Nordberg, Bengt / Steensland, Lars / Thelander, Mats (eds.) Aspects of multilingualism. Proceedings from the Fourth Nordic Symposium on Bilingualism, Brtstrom: Upsala 1987, pp. 51-77.

26 The data is annotated with the Stuttgart-Tübingen Tagset (see the list of abbreviations at the end of this article) 
The German nominal phrase große Übung is integrated into the sentence through the Polish demonstrative pronoun taki. Interestingly, the ending $-i$ in the pronoun taki expresses the masculine gender, whereas the noun Übung is feminine. It could be interpreted as a violation of congruence, but in fact we can observe here an interesting way of building bi-lingual gender agreement. The masculine morphological ending in the pronoun taki can be explained by applying Polish norms of gender assignment with the phonological criterion playing the key role: the final sound of the lemma determines its gender (cf. Kreja 1989: 89). ${ }^{27}$ The masculine flexion morpheme of the pronoun is related to the consonant final sound - in this case $g$ - of the German noun, which is decisive for masculine gender in Polish. ${ }^{28}$ Thus, the German noun is considered by a speaker as a Polish element, and integrated into the sentence according to Polish norms of gender assignment.

Accordingly, the language border between German and Polish at the site of language switch between the Polish pronoun and German nominal phrase reveals a permeable character, as it allows a transfer of grammatical features that are decisive for the integration of the German phrase. It is still observable, but it constitutes a penetrable and passable "threshold".

Interestingly, although the German noun Übung is introduced through the Polish pronoun taki with the masculine ending $-i$, the following German adjective große has a feminine suffix $-e$. So, we observe here a mixed nominal phrase with two different gender assignations to the same noun.

27 Kreja, Bogusław: Z morfonologii i morfotaktyki współczesnej polszczyzny. Ossolineum: Wrocław 1989.

28 Pohl (1987) explains the gender assignement of German loanwords in Polish as follows: „This decision is usually not made according to the gender which the particular loanword has in German, but according to its morphophonemic representation. The final sound of the German noun plays a a key role here. If the final sound is a consonant, the loanword will very probably receive the masculine gender (...)."(Pohl 1987, p. 192-193. my translation).

"Diese Entscheidung wird jedoch - in der Regel - nicht aufgrund der Kenntnis des Genus getroffen, das das jeweilige Lehnwort im Deutschen hat, sondern aufgrund seiner morpho-phonetischen Repräsentation. Dabei spielt der Auslaut des deutschen Nomen die entscheidende Rolle. Lautet das Lehnwort z. B. konsonantisch aus, so wird ihm - in der Regel - das Genus Maskulinum zugeordnet (...).“ 


\subsection{Language switch at the word border}

Example 3: Ten Prüfung caly

\begin{tabular}{|l|l|l|l|}
\hline E.K.6. & Mieliśmy ten & Prüfung & cały \\
\hline $\begin{array}{l}\text { [morpheme for morpheme } \\
\text { translation] }\end{array}$ & (We) had this & test & whole \\
\hline [Phonetics (data)] & & ['prifun] & \\
\hline [Phonetics (Ger. norm)] & & ['pry:fun] & \\
\hline [Syntax] & $\begin{array}{l}\text { [S[NP[PPER: (my)]][VP[VAFIN: mielismy] } \\
\text { [NP[PDAT: ten] [NN: Prüfung] [ADJA: caly]]] }\end{array}$ \\
\hline
\end{tabular}

In the example above, the German noun Prüfung is integrated as an element of the Embedded Language into the morphosyntactic frame of the Matrix Language of Polish (vgl. Myers-Scotton 2010 (2002)). This type of language switch may be interpreted according to Muysken (2000) as insertion: "a single constituent $\underline{B}$ (with words $\underline{b}$ from the same language) is inserted into a structure defined by language $\underline{A}$, with words $\underline{a}$ from that language" (Muysken 2000, p. 7). Insertions display an A...B...A nested structure and their striking structural characteristic is the morphological integration into the Matrix Language.

An interesting aspect is that, according to Poplack's (1980) Equivalence Constraint ${ }^{29}$ the language switch between the noun Prüfung and the adjective caly should not be possible, as it violates word order in German (NP $\rightarrow$ Det ADJ N).

The integration of the German noun occurs according to the Polish rules of gender assignment, with the phonological criterion as the most significant: although Prüfung is feminine, it receives - due to its consonant final sound - the masculine gender. This attributed masculine gender is then decisive for the agreement established through the demonstrative pronoun ten, as well as the adjective caty. Thus, the consonant-final sound of the German noun influences the form of Polish pronoun and the adjective by determining their masculine singular morphological endings $-i$ and $-y$, respectively. Through their inflectional forms, they match the aforementioned ascribed values of the grammatical categories of the noun Prüfung. This grammatical relationship achieved through gender and number agreement is an indication of the permeability of the language border at

29 "The Equivalence Constraint: Code-switches will tend to occur at points in discourse where the juxtaposition of L1 and L2 elements does not violate a syntactic rule of either language, i.e. at points around which the surface structure of the two languages map onto each other." (Poplack 1980, p. 586) 
the analyzed site of language switch. The language border between German and Polish constitutes a "membrane", which allows a transfer of grammatical features between these two languages.

\subsection{Language switch at the morpheme border}

An example of the permeable character of the language border at the language switch between lexical stem and bound morpheme is the substantive Bundesverfassungsgerichtem:

Example 4: Bundesverfassungsgerichtem

\begin{tabular}{|c|c|c|}
\hline P.2.EUV & Trzeba to udowodnić przed & Bundesverfassungsgerichtem \\
\hline [Translation] & It has to be proved for & Federal Consitutional Court \\
\hline [Phonetics (data)] & & bundesferfasunsgeriçtem \\
\hline [Phonetics (Ger. norm)] & & bundəsfદe्ِ'fasunsgəRIçt \\
\hline [Morphology] & & $\begin{array}{l}\text { Bundesverfassungsericht- } \\
\text { INSTR.SING.M }\end{array}$ \\
\hline [Syntax] & \multicolumn{2}{|c|}{ [PP[APPR: vor][NP[NN: Bundesverfassungsgerichtem]]] } \\
\hline
\end{tabular}

The German noun Bundesverfassungsgericht receives the Polish morphological ending -em, which marks the instrumental case, singular number and masculine gender. The process of the assignment of this exact declension morpheme can be clearly traced back to Polish morphological rules. ${ }^{30}$ As in the examples 2 and 3 , the noun Bundesverfassungsgericht receives a masculine gender due to its consonantfinal sound. The instrumental case is determined by the preposition przed and its

30 This example confirms the mechanism of morphological adaptation of German nouns in Polish described by Laskowski (1987): „(...) The foundation for the inflectional adaptation is the reinterpretation of the German noun in its first person singular form into the nominative form of the first person singular in Polish. The primary factor is hereby the phonological form of the final sound in the nominative singular in the source language, the gender of the borrowed noun plays merely a subordinate role." (Laskowski 1987, p. 129, my translation)

“(...) istota mechanizmu fleksyjnej adaptacji sprowadza sie die reinterpretacji niemieckiej formy mianownika 1.poj. danego rzeczownika jako formy mianownika 1. poj. w jezyku polskim, przy czym podstawowym czynnikiem determinujacym kierunek tej reinterpretacji jest fonologiczna postac wyglosu formy N.sg. w jezyku zrodlowym, podczas gdy rodzaj gramatyczny zapozyczonego rzeczownika odgrywa jedynie role podrzedna." 
case government. According to Polish declination rules, a noun which ends with the consonant $-t$ acquires the $-e m$ ending in singular instrumental (cf. Tokarski 2001). ${ }^{31}$

In this mixed utterance, we notice the opening of the word boundary for the integration of the morpheme. However, at the same time, we can observe that the language border is still maintained: the lexeme and morpheme from both languages "meet" each other at an easily identifiable dividing line.

Another interesting example is the noun Readera. It presents an even clearer opening of the internal word border accompanied by a further increased degree of permeability:

Example 5: Readera

\begin{tabular}{|l|l|l|}
\hline T.6.EUV & Idę skopiować & Readera \\
\hline [Translation] & I go copy & reader \\
\hline [Phonetics (data)] & & ridəra \\
\hline [Phonetics (Engl./Germ. norm)] & & Engl. riddə^ / Germ.: ridere \\
\hline [Morphology] & & Reader-GEN.SING.M \\
\hline [Syntax] & $\begin{array}{l}\text { [S[NP[PPER: (ja)]][VP[VVFIN: idę][S[VP[VVINF: } \\
\text { skopiować][NP[NN: readera]]]]] }\end{array}$ \\
\hline
\end{tabular}

The English noun reader - incorporated from English into German and frequently used at German universities - is altered through the addition of the Polish declension ending $-a$. In contrast to the prior example, the rules of morpheme assignment are no longer so unambiguous. Let's proceed exactly like in example 4, examining the three decisive aspects for the declension ending in Polish, namely case, number and gender. As the noun reader ends with a consonant, its gender according to Polish norms is masculine. The valence of the verb skopiować is accusative. It is very interesting that the speaker uses the morpheme $-a$, because according to the Polish declension rules, inanimate masculine substantives have no ending at all in the accusative. The ending $-a$ undoubtedly violates Polish morphological rules; however, in current spoken Polish, the use of the morphological ending $-a$ in the accusative with inanimate substantives is indeed very frequent

31 This example can be considered as insertion according to Muysken (2000), as the noun Bundesverfassungsgericht is modified morphologically and embedded into the structure defined by Polish as the Matrix Language providing the case morpheme -em. 
(Bugajski 2008). ${ }^{32}$ Thus, it is interesting to notice that language mixing also reflects language variation in the current Polish language.

Aside from morphological alternation, there is also a phonological change: the consonant $r$ at the border between the English loanword and the Polish morphological ending is rolled and pronounced according to Polish phonological rules as $[\mathrm{r}$ ] instead of English alveolar approximant [u] or German [e $]$ ]. The phonological influence and the morphological integration are indications of the permeable character of the language border. In fact, the phonological influence beyond the language border may be even interpreted as sign of the emergence of a liminal space as the sphere of impact between these two languages increases and does not stop at the morpheme border, but in fact goes beyond. This example can thus be located between the categories of permeability and liminality.

\section{Conclusion}

The aim of this article was to deliver an insight into German-Polish language mixing, and to propose a theoretical framework illustrating and explaining the language contact-induced processes of language border opening and crossing.

The data analysis shows that - in the process of border crossing - the permeability of language borders enables transfer of grammatical features from two languages in contact through building of a coherence and agreement, morphological integration or phonetic alternation.

The presented data analysis reveals that especially the theory of the border can be fruitful for the discussion of language-mixing phenomena. This approach gives an innovative opportunity to bring together phonetic, morphological and syntactic aspects into the analysis, which so far have been rarely integrated into a single framework (cf. Muysken 2013, p. 193). Through the incorporation of the concept of the border into the linguistic analysis, I provide interdisciplinary insight into the investigation of structural aspects of language mixing, and contribute to the theory of the border from a linguistic perspective.

32 Bugajski, Marian: „Puszczam strzala, bo mam stresa“. In: Dąbkowski, Grzegorz (ed.): Reverendissimae Halinae Satkiewicz cum magna aestimatione. Warszawa 2008, pp. 67-75. 


\section{List of gloss abbreviations}

ADJA - attributive adjective

APPR - preposition

GEN - genitive

INSTR - instrumental

$\mathrm{M}$ - masculine

$\mathrm{NN}$ - common noun

NP - nominal phrase

PDAT - attributive demonstrative pronoun

$\mathrm{PP}$ - prepositional phrase

PPER - non reflexive personal pronoun

SING - singular

VAFIN - auxiliary verb, finite

VP - verbal phrase

VVFIN - full finite verb

VVINF - full infinitive verb

\section{Literature}

Audehm, Katrin / Velten, Hans Rudolf: Transgression, Hybridisierung, Differenzierung, Zur Performativität von Grenzen in Sprache, Kultur und Gesellschaft. Rombach: Freiburg 2007.

Belliger, Andréa / Krieger, David J. (ed): Ritualtheorien. Westdeutscher Verlag: Opladen/Wiesbaden. 1998.

Berthoud, Anne-Claude / Grin, François / Lüdi, Georges (eds.): Exploring the Dynamics of Multilingualism: The DYLAN project. Benjamins: Amsterdam/ Philadelphia 2013.

Bugajski, Marian: „Puszczam strzala, bo mam stresa“. In: Dąbkowski, Grzegorz (ed.): Reverendissimae Halinae Satkiewicz cum magna aestimatione. Warszawa 2008, pp. 67-75.

Bhabha, Homi: The Location of Culture. Routledge: London 1994.

Cichon, Peter / Czernilofsky, Barbara / Tanzmeister, Robert / Hönigsperger, Astrid (eds.): Entgrenzungen. Für eine Soziologie der Kommunikation. Praesens: Wien 2005.

Clyne, Michael: „Constraints on code-switching: how universal are they?” In: Wei, Li (ed.): The Bilingualism Reader. Routledge: London 2000, pp. 257-80. 
Cunha, Conceicao et al. (eds.): Über Grenzen sprechen. Mehrsprachigkeit in Europa und der Welt. Königshausen \& Neumann: Würzburg 2012.

Dąbkowski, Grzegorz (ed.): Reverendissimae Halinae Satkiewicz cum magna aestimatione. Warszawa 2008.

Erfurt, Jürgen (ed.): „Multisprech“: Hybridität, Variation, Identität. (Osnabrücker Beiträge zur Sprachtheorie, Bd. 65). Osnabrück 2003.

Erfurt, Jürgen (ed.): Transkulturalität und Hybridität. L'espace francophone als Grenzerfahrung des Sprechens und Schreibens. Peter Lang: Frankfurt/M. et al. 2005.

Erfurt, Jürgen: „'de même I hope j’te bother pas': Transkulturalität und Hybridität in der Frankophonie“. In: Erfurt, Jürgen (ed.): Transkulturalität und Hybridität. L'espace francophone als Grenzerfahrung des Sprechens und Schreibens. Peter Lang: Frankfurt/M. et al. 2005, pp. 9 - 36.

Erfurt, Jürgen: „'Multisprech': Migration und Hybridisierung“. In: Erfurt, Jürgen (ed.): „Multisprech“: Hybridität, Variation, Identität. (Osnabrücker Beiträge zur Sprachtheorie, Bd. 65). Osnabrück 2003, 5-34.

Földes, Csaba: Mehrsprachigkeit, Sprachenkontakt und Sprachenmischung. (Flensburger Papiere zur Mehrsprachigkeit und Kulturenvielfalt im Unterricht; 14/15). Flensburg 1996.

Geisenhanslüke, Achim/Mein, Georg (eds.): Schriftkultur und Schwellenkunde. transcript: Bielefeld 2008.

Gogolin, Ingrid / List, Günther / Graap, Sabine (eds.): Über Mehrsprachigkeit. Stauffenburg-Verlag: Tübingen 1998.

Gogolin, Ingrid: „Sprachen rein halten - eine Obsession“. In: Gogolin, Ingrid/ List, Günther/ Graap, Sabine (eds.): Über Mehrsprachigkeit. Stauffenburg-Verlag: Tübingen 1998, pp. $71-96$.

Greco, Luca / Renaud, Patrick / Taquechel Roxana. "Chapter 2. The practical processing of plurilingualism as a resource in professional activities". In: Berthoud, Anne-Claude / Grin, François / Lüdi, Georges (eds.): Exploring the Dynamics of Multilingualism: The DYLAN project. Benjamins: Amsterdam/Philadelphia 2013, pp. 33-58.

Gugenberger, Eva: „Der dritte Raum in der Sprache. Sprachliche Hybridisierung am Beispiel galicischer Migrant/inn/en in Buenos Aires“. In: Cichon, Peter / Czernilofsky, Barbara / Tanzmeister, Robert / Hönigsperger, Astrid (eds.): Entgrenzungen. Für eine Soziologie der Kommunikation. Praesens: Wien 2005, pp. 354-376.

Hinnenkamp, Volker / Meng, Katharina (2005): „Sprachgrenzen überspringen. Sprachliche Hybridität und polykulturelles Selbstverständnis: Einleitung “. In: Hinnenkamp, Volker / Meng, Katharina (eds.): Sprachgrenzen überspringen. 
Sprachliche Hybridität und polykulturelles Selbstverständnis. Narr: Tübingen 2005, pp. 1-16.

Hinnenkamp, Volker / Meng, Katharina (eds.): Sprachgrenzen überspringen. Sprachliche Hybridität und polykulturelles Selbstverständnis. Narr: Tübingen 2005.

Jańczak, Barbara / Jungbluth, Konstanze / Weydt, Harald (eds.): Mehrsprachigkeit aus deutscher Perspektive. Narr: Tübingen 2012.

Jungbluth, Konstanze: „Aus zwei mach eins: Switching, mixing, getting different“. In: Jańczak, Barbara/ Jungbluth, Konstanze/ Weydt, Harald (eds.): Mehrsprachigkeit aus deutscher Perspektive. Narr: Tübingen 2012, pp. 45-72.

Kimura, Goro Christoph : "Strategie komunikacji językowej na polsko-nemieckim pograniczu." In: Koutny, Ilona / Nowak, Piotr (eds.): Język. Kommunikacja. Informacja. Language. Communication. Information. (Poznań), 8/2013, pp. 109-124.

Koutny, Ilona / Nowak, Piotr (eds.): Język. Kommunikacja. Informacja. Language. Communication. Information. (Poznań), 8/2013.

Kreja, Bogusław: Z morfonologii i morfotaktyki współczesnej polszczyzny. Ossolineum: Wrocław 1989.

Laskowski, Roman: "Mechanismen der morphologischen Adaptation deutscher Nomina im Polnischen.” In: Pohl, Alek / Vincenz, Andre (eds.): Deutsch-polnische Sprachkontakte. Böhlau: Köln 1987, pp. 113-130.

McCormick, Kay: Language in Cape Town's District Six. Oxford University Press: Oxford 2002.

Muysken, Pieter: “Two linguistic systems in contact.” In: Bhatia, Tei K. / Ritchie. William C. (eds.): The Handbook of Bilingualism. Blackwell: Oxford 2013, pp. $147-168$.

Muysken, Pieter: Bilingual speech: a typology of code-mixing. Cambridge University Press: Cambridge 2000.

Myers-Scotton, Carol: Contact Linguistics. Oxford University Press: Oxford 2010 (2002).

Pohl, Alek / Vincenz, Andre de (eds.): Deutsch-polnische Sprachkontakte. Böhlau: Köln 1987.

Pohl, Alek: „Zum Problem des Genus deutscher Lehnwörter im Alt- und im Mittelpolnischen."In: Pohl, Alek / Vincenz, Andre de (eds.): Deutsch-polnische Sprachkontakte. Böhlau: Köln 1987. pp. 191- 205.

Poplack, Shana: "Contrasting patterns of code-switching in two communities." In: Wande, Erling / Anward, Jan / Nordberg, Bengt / Steensland, Lars / Thelander, Mats (eds.) Aspects of multilingualism. Proceedings from the Fourth Nordic Symposium on Bilingualism. Brtstrom: Upsala 1987, pp. 51-77. 
Poplack, Shana: "Sometimes I'll start a sentence in Spanish y termino en Español: Toward a typology of code-switching". In: Linguistics 18, 1980, pp. 581-618.

Rampton, Ben: Crossing: language and ethnicity among adolescents. St. Jerome Press: Manchester 2005.

Parr, Rolf: „Liminale und andere Übergänge. Theoretische Modellierungen von Grenzzonen, Normalitätsspektren, Schwellen, Übergängen und Zwischenräumen in Literatur und Kulturwissenschaft". In: Geisenhanslüke, Achim/Mein, Georg (eds.): Schriftkultur und Schwellenkunde. transcript: Bielefeld 2008, pp. 11-64.

Tokarski, Jan: Fleksja Polska. PWN: Warszawa 2001.

Turner, Victor W.: "Betwixt and Between: The Liminal Period in Rites de Passage". In: Helm, June (ed.): Symposium on New Approaches to the Study of Religion: Proceedings of the 1964 Annual Spring Meeting of the American Ethnological Society. American Ethnological Society: Seattle 1964, pp. 4-20.

Turner, Victor W.; "Liminalität und Communitas". In: Belliger, Andréa / Krieger, David J. (ed): Ritualtheorien. Westdeutscher Verlag: Opladen/Wiesbaden. 1998, , pp. 251-262.

Wande, Erling / Anward, Jan / Nordberg, Bengt / Steensland, Lars / Thelander, Mats (eds.) Aspects of multilingualism. Proceedings from the Fourth Nordic Symposium on Bilingualism. Brtstrom: Upsala 1987.

Wei, Li (ed.): The Bilingualism Reader. Routledge: London 2000. 


\title{
Helena Topa Valentim
}

(Lisboa)

\section{Boundary, a metalinguistic concept at the core of language deformability}

\begin{abstract}
In diesem Artikel wird das Konzept der Grenze als methodologisches Instrument zur Erklärung sprachlicher Phänomene behandelt. Der Fokus liegt hierbei auf der Betrachtung der Art und Weise, in der dieses metalinguistische Konzept eine Bezeichnungsdomäne integriert, die ein kompositorisches Konstrukt ist und deren Definition durch ein relationales Netz der Repräsentationen auf unterschiedlichen Ebenen determiniert wird. Ferner wird ihre Operationalität in der Beschreibung der linguistischen Alterität verifiziert, die direkt von der metalinguistischen Differenzierung abhängt.

Der reflexive Charakter der metalinguistischen Aktivität verlangt den Bezug auf das Repräsentationssystem, welches eine Art von symbolischer Übersetzung bilden kann. Laut der Theorie Predicative and Enunciative Operations (PEO), welche von dem französischen Sprachwissenschaftler Antoine Culioli vorgeschlagen wurde, bezieht sich die metalinguistische Repräsentation hauptsächlich auf die Konstruktion der Grenzen, um das Funktionieren von Sprache zu erklären. Dieses Model zeigt die Form einer topologischen Struktur (cf. Culioli / Declés 1981), die durch Mathematik inspiriert wird. Die Anwendung der Topologie und ihrer Terminologie zeigt einerseits ihren Status unter unterschiedlichen Methoden der metalinguistischen Repräsentation insbesondere auf kognitiver Ebene und andererseits die linguistischen Produktions- und Reproduktionsprozesse, die den Sprachgebrauch ausmachen.
\end{abstract}

Schlagworte: Aussageform, Grenze, Bezeichnungsdomäne

Keywords: Enunciation, Boundary, Notional Domain, Language Deformability

\section{Introduction}

When examining the way languages work, we are led to believe that language activity is generally understood as appealing to metalinguistic representational parameters. At this abstract, cognitive level, and in an attempt to discover phenomena and to explain them, there is primarily a boundary between what is immaterial - "what we mean" - and what has materiality (verbal materiality in this case) - "what we say". As we speak and communicate with each other, we try to match those two things, but we do so by using multiple modulations, and often with many mistakes and even with misunderstandings. 
I start by considering the boundary as a primitive cognitive concept which shapes the way we represent the world. This way of representing the world naturally results from our perception of otherness; more specifically, it results from the phenomenon of transition, which is identifiable first of all in space-time (after Einstein, no more categories dissociated). Therefore, we have an abstract sense of boundary, taken here as a topological primitive notion corresponding to an operational concept in the framework of Predicative and Enunciative Operations (PEO), proposed by the French linguist Antoine Culioli. Through this theoretical framework, Culioli proposes a metalinguistic representation in order to explain the global functioning of language.

\section{"Enunciate" / Utterance and language deformability}

The understanding of how language works allows us to identify the concept of "enunciate", a term with which we can designate linguistic sequences. As Culioli states (2002, p. 27), the choice of the term "enunciate" instead of the English term "utterance" can be justified. "Enunciate" is an old term. Seneca translates the term lekton (what the Stoics called to something incorporeal, i.e., something without materiality) with the word enuntiativum. After the Middle Ages, there was the relationship between the dicibile (the speakable) and the dictum (the said). The Middle Ages scholars conceived a dictum and a modus, that is, a sort of thought content or propositional content. Therefore, we have the conception of an immaterial representation, an abstraction. The term enuntiativum, employed by Seneca to explain what lekton is, has enuntiare as the verb, with the meaning of "making out" or "to bring up". That's why "enunciate" assumes the significance of a transition from something "speakable" to something "said". The concept of "enunciate" includes this sense corresponding to something which is not a priori; on the contrary, it is constructed by an "enunciator" and reconstructed by a "coenunciator". In English the available word is "utterance" (which, for simplicity, we will use from now on). Utter means "to externalize" (etymologically, $u t=o u t$ ), but with an emphasis on the agent. In contrast, "to enunciate" puts the emphasis on the enunciating act, on the construction or the production of something.

Consequently, the enunciator responsible for the utterance's production is not identified with the speaker or the sender. The enunciator is the subjective origin, which results necessarily as an intersubjective entity. Thus, underlying any statement, there is always an enunciator and a coenunciator as theoretical entities - not as flesh and blood entities. In contrast, pragmatically speaking, the speaker and the sender (in the sense of Jackobson's proposal) are individuals and flesh and blood entities - in the specific case of the sender, with a focus on coding. 
We can therefore look in this manner at language activity: conceiving the relationship between something abstract and inaccessible because of its immateriality, and something accessible and materialized. In other words, language operates between something cognitive or mental, and an utterance. In linguistic activity, we move from the "speakable" to the "said"; in order to understand the way it functions, we raise at least two questions: about the way one operates this transition, and about the way we can manage the boundary between these two dimensions.

Thus, the enunciator is the agent, the responsible entity for this transition, and the one who constructs meaning. However, as the constructed meaning is also reconstructed, it would be interesting to realize the way this non-symmetric mechanism works between both enunciator and coenunciator - the fact that, very often, there is no perfect understanding or transparency on this issue is due to this asymmetry. Benveniste (1966) theorizes about the "formal apparatus of enunciation", but the question on how a subjective activity can be intersubjective remains without a conclusive answer.

When speaking about intersubjectivity, we speak of the otherness inscribed at the core of linguistic activity, which lies at the boundary between entities in their radical individuality. As many authors have stated, the explanation for the constant modulation that characterizes any language lies in the concept of intersubjectivity. An utterance is always modulated. These modulations acquire the form of a game of grammatical categories, which obtain different values of referential determination. Thus, we have a subjective game, a mode game, a time game, and even an intonational game.

Look for instance at this interactional sequence of utterances (adapted from Culioli 2002, pp. 219-220):

A- In gyms people don't really practice sports. They run, they stretch, they jump... People who really practice any sport make their exercises in a judicious and targeted manner.

$B$ - Yes, but why not say that running, stretching and jumping the way people do in gyms is already practicing sports? After all, it is to stir. Don't you think it is better to stir a little bit than not doing anything?

The construction of the different values happens through a number of modulations. This is a simple example of how we are always facing representational deformability, discontinuities, and heterogeneous phenomena, and this sequence illustrates exactly what enunciation is: namely, something other than strict syntax, semantics or pragmatics. As a construct resulting from intersubjective modulation and adjustment, enunciation crosses all these dimensions, enunciation is transcategorical: it 
is simultaneously prosodic, syntactic, semantic and pragmatic. In this sense, the heterogeneity of the intersubjective modulation or adjustment phenomena cause the barriers (boundaries) of the traditional linguistics sub-disciplines to fall.

The focus of our interest should fall on the effects of non-coincidence - on the necessary adjustments between speakers - because through linguistic activity we operate a transition from a non-material representation to a material representation. In other words, through linguistic forms, we operate a transition from an abstract and cognitive representation to the visibility and tangibility of linguistic forms.

The explanation of how this "embodiment" allows an adjustment between the speakers requires an anthropological linguist's perspective. It demands that we consider all interactional phenomena, not excluding the prosodic and pragmatic phenomena. Thus, on the basis of transcategoriality, we can examine another boundary: the one often established between what is linguistic and what is not linguistic - or extra-linguistic. Considering that referring is one of the language activity dimensions, the question is to know whether reference is external to linguistics. Any answer has to consider the fact that reference to the situation is not foreign to language activity, as it will contribute to the production and the recognition of utterances. In order to prove this, we only have to look at how the big questions of reference are internal to language activity - for instance, something exists or doesn't exist, something is set or isn't set, etc.

Culioli, in a published interview (2002, p. 73), compared reference to what happens when you show children a movie and ask them to tell you what they saw. On the one hand, children know that what they're telling you didn't actually happen: it's a film. On the other hand, there is always "the illusion of the film": they narrate it as if the events actually happened. We can recognise it in the temporal values attached to the linguistic forms they construct. In fact, in terms of what language allows us to refer: both, something that happened (a trip that I made to Paris, for instance) and something that did not happen (a film or a dream that I report) are referential. From the linguistic point of view, both are real events because they refer to representations that don't have the status of reality. Therefore, we always speak about the visible and the invisible, taking into account that everything is relevant to language. The linguistic forms are by definition constructed on those issues that we tend to consider not being linguistically relevant, such as inference or, as Culioli (ibid.) expresses it, what we designate as "common and shared knowledge".

Moreover, when we consider the transcategorical nature of the study of language, we study the complex relationship between what is inside the text (the intratextual relationships) and the situational context. The fact that language is not a homogene- 
ous concept proves this complexity. As a representational activity, language allows us to build representations. As a referential activity, language allows us to construct reference (i.e., it refers to what "we speak about"). On the other hand, language is a regulatory activity; thus, in addition to the regulations that are internal to language (meaning that all languages are characterized as both stable and deformable), there are regulations between speakers. We as speakers always want to lead the other to the representations that we aim at, and in doing so incur the risk of failure, and for that reason we resort to any necessary adjustments in order to avoid this failure.

Linguistic forms play a key role in this intersubjective game of building-rebuilding representations and reference. Linguistic forms are markers of cognitive and linguistic operations simultaneously, and they underlie the utterances and referential values. For instance, the use of the indicative or the subjunctive mood in propositional complements of subjective verbs (as to believe or to think) is a case of this cognitive and linguistic operations marking. In Portuguese, as in other Romance languages, the opposition indicative / subjunctive marks intersubjective values, described as modality values.

In the following utterance, the use of the indicative mood (telefonou) in the subordinate clause indicates the enunciator's belief. The enunciative distance naturally implicated by any belief (which is not a certainty) is marked by the verb (acredito) in the main clause.

(2) Acredito que a Ana telefonou ${ }_{\text {indicativo }}$ (I believe that Ana called.)

In the utterance (3), the use of the subjunctive mood in the subordinate clause (tenha telefonado) indicates that the enunciator drifts away from his belief.

(3) Não acredito que Ana tenha telefonado conjuntivo (I don't believe that Ana called.) In a negative interrogative sentence like (4), the use of the indicative mood in the subordinate clause is oriented to what the enunciator believes, and simultaneously to what he believes his interlocutor should believe in. Consequently, it expresses the enunciator's belief, presupposing "I believe". That's exactly the reason why this sentence has a controversial interpretation.

(4) Não acreditas que Ana telefonou indicativo ?(Don't you believe that Ana called?) It is very common that a small linguistic mark - even a simple intonation mark is enough to trigger various types of operations and, consequently, to introduce a relevant change.

(5) Foi um belo dia. (It was a wonderful day.)

(6) ${ }^{\star}$ Se foi um belo dia. (literally: If it was a wonderful day.) 
(7) Ah! Se foi um belo dia! (literally: Oh! If it was a wonderful day! - which in English would be "Oh! It was really a wonderful day!")

We observe that the first utterance (6) isn't acceptable, whereas the last utterance (7) is acceptable. Through the ascending intonation mark, (7) corresponds to the determination of a high degree of value for the property of being "um belo dia" (a wonderful day). Consequently, it acquires an appreciative modal value. This same linguistic construction, without this specific intonation characterization (as in 6), wouldn't have this modal value: it would be an assertion and wouldn't be acceptable.

\section{Notional Domain: a metalinguistic representation}

Heterogeneity is inherent to any language, and represents a challenge to developing theories about it. If heterogeneity of phenomena arises primarily, any theory must address the problem of how this transition from homogeneity to heterogeneity operates. Through this process, you are on the way to finding some form of homogeneity. Therefore, theorization shows nothing more than a "deformable consistency" (Culioli 2002, p. 88). When we emphasize this deformability, we choose a specific epistemological perspective consisting of observation of the data, identification of the relevant problems, and consequently, conception of a descriptive and explanatory reasoning. The linguistic facts reveal that there is always a "subjective grammar", a set of lexical and adjustment operations. Therefore, it is essential to adopt a scientific paradigm based upon the classical logic. Actually, linguistic phenomena cannot be reduced to a binary perspective or to an exclusivity of values, as conceived by the trait theory of structural grammar. But the boundary between those apparent exclusive values is not something dimensionless. So it is evident that there is a need for devising a gradient which enables "a more or a less value". It enables, more specifically, the existence of some values which are neither one thing nor the other: that is to say, some values which do not correspond to a certain property any longer, but also do not correspond yet to another property. This gradient becomes an appropriate metalinguistic feature to account for the deformability of cognitive representations.

The next utterances show empirically how this proposal of a dimensionless boundary is absolutely operative in a metalinguistic reasoning.

(8) John is tall.

(9) John is very tall.

(10) John is really tall!

(11) John is tall, tall!

(12) John is a tower! 
(13) John is not really tall.

(14) John is kind of tall.

(15) John is not tall.

(16) You can't say that John is tall, but you can't say that he is small.

(17) This is not a house, this is a hole.

(18) This one, yes, is a real house / one of those houses!

(19) This is not a house; this is the house!

(20) This is not really a house even if it has everything to be it.

In both groups of utterances - from (8) to (16) and from (17) to (20) - we're dealing with the cognitive representations of what we lexicalize as "tall" in the first group, and as "house" in the second. The modulations and the consequent deformability are introduced through small linguistic marks. The stability in all these utterances is definable in terms of each of these notions: tall and house correspond both to representations constructed culturally, and simultaneously dependent upon the enunciator's individual experience. But we can recognize above all a relevant modulation, explainable by operations, both of language and cognitive order.

Many of these empirical facts cause complex problems in the study of languages. Structuralism worked on the "all or nothing", hence with a clear defined boundary with no extension. However, as a matter of fact, and as these empirical data show, we don't have a two-value system. In these utterances, we have the "really tall" value (10), but we also have the "not really tall" (13) and the "kind of tall" (14) values.

We can understand this different configuration of boundaries through empirical data from texts produced in an interaction on cooking, as proposed by Culioli (2002, pp. 217-218), recalling Claude Lévi-Strauss (Le cru et le cuit 1964 / The raw and the cooked, 1969).

Culioli begins by referring to the fact that cooking is a cultural issue, a question of representation cognitively inscribed in our minds. As a representational construction, cooking involves two states: the "unbaked" and the "baked". A potato, for instance, is unbaked before baking, but from the moment it begins to bake, it is no longer strictly unbaked, but it is not yet baked. During baking, the potato becomes more and more baked. So, when a potato is baking, the more baked it is and the less unbaked it becomes. Thus, there is a moment in which it is still not fully baked, even if it is no longer truly unbaked. After a while, there is a moment when it's already baked. We consider the process to be unidirectional because, according to our knowledge, it is no longer unbaked at all, and once it is baked, it is definitively baked. According to our cultural knowledge, baked is an irreversible state: we don't have something like “* debaked", as we have, for instance, "defrosted". 
The relevant piece from this empirical example pointed in Culioli (2002, p. 218) is that, as a consequence of this process, we have (exactly when baking hasn't started) "unbaked" at the beginning, and then at the end of baking we say "it's baked". Thus, there is one last moment when it is still unbaked, even in to a minimal degree, the same way there is a moment when we declare "it's baked". So we build a state at one pole (unbaked), and on the other pole we build another state (baked). The condition of being baked results from a process that includes an intermediate state with a first point in which it isn't already totally unbaked, and one last point in which it is still not truly baked.

Using this empirical situation, Culioli demonstrates that we cognitively build a first point of "baking" and a last point of "unbaking", but in between these two values we construct a boundary which integrates a gradient, and which includes both attractors (unbaked / baked) and the values of less and less unbaked and more and more baked.

In this case, the complementary arises in a completely different way than in the case of systems having two values, where each value is necessarily the opposite of the other. Within this dispositive, the complementary of "unbaked" can be "baked", but can also be the boundary of "baked". In other words, the complementary of "unbaked" is defined as the time from when it is no longer unbaked (in the strict sense), and when it is also not yet baked.

Notion of UNBAKED (adapted from Culioli 2002, p. 118)

$\begin{array}{lcc}\text { Interior } & \text { Boundary } & \text { Exterior } \\ \text { Gradient } & & \\ \mathrm{X}-\mathrm{-} \text { - } & \\ \text { Truly unbaked } & \text { not yet truly unbaked }\end{array}$

We could take into account the case of the complementarity between unbaked and baked, and incurring the recognition of binary opposition just as the structuralism did. However, we can consider the complementary in a way that it corresponds to "unbaked" and the boundary to the other value. In some cases, we can even take into account the boundary isolating it as we wish in relation to "unbaked and / or baked". For instance, "The spaghetti is al dente" (al dente being the point of baking pasta ("pasta al dente") when it is baked "perfectly", offering a slight resistance to the bite).

As Culioli acknowledges, we realize that in order to describe these phenomena, a classification isn't enough. It is necessary to make a calculation. These are phenomena that have led Culioli, with the help of Jean Blaize Grize (in logicalmathematical aspect) and François Bresson (cognitive psychology), to introduce 
a topological structure which corresponds to a primitive cognitive devise. All notions (of unbaked, baked as well as any other notion like home, coming, eating, etc.) are representable by a domain - a Notional Domain - with topological properties. In addition to the dimensioned Boundary, the Notional Domain consists of an Interior and an Exterior. As the notion is / $\mathrm{P} /$ (here as a variable), the Notional Domain is (p, p $)^{1}$.

The Notional Domain allows one to distinguish topologically what is internal (what belongs to it), what is external (what does not belong to it - that is, the alterity), and what is on the boundary of this domain. As a topological structure, the Notional Domain is representable in space coordinates as having an Interior, an Exterior and a Boundary.

The Interior zone (I) is where what is truly /P/ (i.e., with all the properties /P/) is situated.

In both utterances, (8) and (9), the enunciator builds a linguistic occurrence of the notion /TALL/ located within the notional domain.

(8) John is tall.

(9) John is very tall.

The Interior defines an open area that is organized around an Organizing Centre which functions as the Attracting Centre, where the notion's high degree properties are located. Thus, the Organizing Centre is where you find the Type Occurrence of a notion.

In the following utterances (10), (11) and (12), the enunciator makes use of various linguistic resources to build linguistic occurrences of the same notion, / TALL/, located precisely in relation to the Attracting Centre. Consequently, these linguistic occurrences have the value of high degree. Producing these utterances, the enunciator says that "John" (the enunciate subject) has all the properties inherent to "being tall".

(10) John is really tall!

(11) John is tall, tall!

(12) John is a tower!

The same thing happens in utterances (18) and (19), with the difference of being related to another notion, /HOUSE/ also presenting different linguistic resources in order to construct the high degree. For instance, in utterance (19), the definite

1 In ( $\mathrm{p}, \mathrm{p}$ ), $\mathrm{p}$ represents what is /P/ (the validation zone); $\mathrm{p}^{\prime}$ represents what is not /P/ or is /non- $\mathrm{P} /$ (the complementary or non-validation zone). 
article is the mark of this identification operation between the linguistic occurrence and the notional Attracting Centre.

(18) This one, yes, is a real house / one of those houses!

(19) This is not a house; this is the house!

In the Interior of the Notional Domain, all the notion's occurrences are indiscernible, i.e. identified one with the other through the relation they all have with the Type Occurrence. So, it is not possible to establish a final occurrence. This metalinguistic reasoning is marked by the indefinite article in (19) - "a house".

Turning back to the example of cooking, it is interesting to show that, in order to mean "unbaked" before even the slightest change, we say something like:

(21) It's unbaked, really unbaked.

The possibility of an utterance like (21) means that we can construct a value through a self-localization, that is to say, referring to "what is unbaked, justifiably referred to as unbaked". This leads to an inaccessible representation, which can only be said and cannot be shown which corresponds precisely to the construction of the high-degree.

Continuing the topological explanation of the different values that we can associate to a linguistic construction, we can define a Gradient in the Interior of the notional domain, through which the degree of approximation or detachment of the linguistic occurrence in relation to the Organizing Centre is regulated. This situation is illustrated in utterances (13) and (14):

(13) John is not really tall.

(14) John is a bit tall.

However, the Notional Domain also includes the Exterior zone which contains what is not truly $/ \mathrm{P} /$ concerning the construction of a linguistic complementary, i.e. everything that doesn't show the inherent properties of the notion. Therefore, the established relations between the values of a notion in its Interior, and the values in the Exterior, are complementary.

(15) John is not tall.

(17) This is not a house, this is a hole.

In (15), the fact of excluding the properties of the notion /TALL/ implicates the construction of its complementary notion: if "he is not tall", then it is presupposed that "he is small". In (19), the enunciator constructs the complementary of something "not being a house" as being "a hole". The complementary is, in these cases, linguistically constructed. 
Utterances (16) and (20) illustrate the construction of an occurrence in the Boundary zone of the Notional Domain, the zone containing what is no longer $/ \mathrm{P} /$ and yet is not really /not-P/.

(16) You can't say that he is tall, but you can't say that he is small.

(20) This is not really a house even if it has everything to be it.

From a topological perspective, this issue is also applicable to the metalinguistic representation of the linguistic occurrences which are constructed in relation to a time axis (cf. Dufaye 2009, pp. 109-110).

(22) I have lived here for 5 years.

(23) I have lived here since my son was born.

In utterances like (22) and (23), how can we represent the boundary between the linguistic event ("have lived here") and the time interval specified by the adverbial? We would say that, once again, it depends on the point of view: in the first case, the boundary belongs to the linguistic event "have lived here", whereas in the second case it belongs to the time interval specified by the adverbial "since my son was born."

\section{Final remarks}

One of the most crucial characteristics of this metalinguistic device lies exactly in the design of the boundary, not as a dimensionless threshold, but as having a structure itself and therefore also having a dimension. The result is a more complex system that mainly helps to explain the diversity of specific configurations in the utterances' determination, thus providing some metalinguistic representations that help to build the "story" of linguistic representations. Therefore, it doesn't deal with objects as isolated entities with clear-cut boundaries. In this sense, it is a procedure of abstraction: the objects are abstractly constructed, acquiring a theoretical status and showing how language refers to itself and not to an extra-linguistic object. The utility of this approach also lies in the fact that it reveals language to be more complex than a compositional analysis proposes. One starts from the principle that, in order to build utterances, we are all provisioned with the same device of construction-deconstruction, which allows us to identify linguistic units as traces of operations. It also reveals that we all have a stock of common operations at our disposal, and that is why we can re-construct what has been produced by others.

Therefore, there is a mental activity to which we can give a kind of crude representation, but we'll always face difficulties in realizing it. As Culioli suggests, 
we know that what happens in and through language is not linear; it can only be represented in a very complicated geometric organization. Through linguistic activity, we're always building a certain type of object that is provided with formal properties. This object will be anchored in a reference space and be subjected to a permanent intersubjective adjustment.

This perspective also allows us to deal with another type of boundary: the diversity of languages. Investigating the diversity of languages, and trying simultaneously to build a theory of language, involves addressing the problem of the comparability between languages, or always looking for what is common among their diversity. Addressing the problem of comparability between languages necessitates a higher level of abstraction. Each language is unique even if we can translate it. Thus, because of its comparability, it is possible to find a set of operations that exists in all languages. On the one hand, we have the lexical and grammatical notions based on operations; on the other hand, we have the characteristic markers of a given language. What varies from language to language is the correspondence between markers and operations which are specific to a given language.

Therefore, a language is neither a code nor a nomenclature. We deal with procedures, categorization processes, representation and adjustment resources, all defining a deformable system. This deformability means that there are no finished utterances. Every utterance is produced by an enunciator, such that the coenunciator will by himself reconstruct representations through the markers. The coenunciator never avoids that the phenomena such as polysemy, ambivalence, vagueness, and therefore an eventual misunderstanding can occur.

Such a view on the functioning of language leads us to some interesting questions, particularly about how language relates to reality. According to this reasoning, the question of the outside and the inside, and thus the concept of the Boundary is put another way, and as with any other categories, it cannot be forcibly put into the perspective of "all or nothing". This kind of approach leads to an increase in significance, as it is contrary to the ancient linguistic rationality that doesn't address the issue of the unsayable, because it doesn't consider the relevance of intersubjectivity and adjustment.

In this sense, and also due to this idea of Boundary as a metalinguistic concept with dimension, language is unlimited. Because of the deformability principle, we can theoretically say anything, even the unsayable, and there is never a final word. It is this operation is that allows for the existence poetry, and that reveals the system's complexity which results from constant adjustments. 
Boundary, a metalinguistic concept at the core of language deformability 261

\section{References}

Benveniste, Émile: Problèmes de linguistique générale. Volumes 1 and 2. Gallimard: Paris 1966.

Culioli, Antoine: Variations sur la linguistique. Entretiens avec Frédéric Fau. Klincksieck: Paris 2002.

Culioli, Antoine: Pour une linguistique de l'énonciation. Volume II. Collection L'Homme dans la Langue, Ophrys: Paris 1990.

Culioli, Antoine / Desclés Jean-Pierre: Systèmes de représentation linguistiques et métalinguistiques. Coll. ERA 642, Université Paris VII, DRL, 1981.

Culioli, Antoine et al.: La théorie d'Antoine Culioli. Ouvertures et incidences. Éditions Ophrys: Paris 1992.

Declès, Jean-Pierre: «Quelques opérations de localisation». Projet interdisciplinaire de traitement formel et automatique des langues et du langage (PITFALL) 15 and 16, Université Paris 7: DRL, 1975.

De Vogüe, Sarah: «La langue entre discours et cognition». In: Actes du colloque international pour les 10 ans de la MSHS de Poitiers. Université Paris X - Paris Ouest Narterre La Défense / CNRS: UMR 7114, 2011.

De Vogüe, Sarah: «Construction d'une valeur référentielle: entités, qualités, figures». La référence 2, Travaux linguistiques du CERLICO 12, 1999, pp. 77-106.

Dufaye, Lionel: Théorie des opérations énonciatives et modélisation. Ophrys: Paris 2009.

Franckel, Jean-Jacques: «Situation, contexte et valeur référentielle». Pratiques 129/130, 2006, pp. 51-70.

Valentim, Helena T. / Lejeune, Pierre: „Contexto ou condição de interpretação do enunciado“. Cadernos WGT. Centro de Linguística da Universidade Nova de Lisboa - Faculdade de Ciências Sociais e Humanas: Lisboa 2009, pp. 3-11. 
